\title{
Alkaline Chemistry of Transuranium Elements and Technetium and the Treatment of Alkaline Radioactive Wastes
}

Prepared for the U.S. Department of Energy Office of Environmental Management

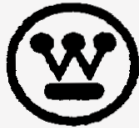


IEeAL DISCLAMER

This report was prepared as an account of work sponsored by en eqency of the United States Government. Neither the

United States Government nor any agency thereof, nor any of their employees, nor any of their contractors, subcontractors or their employees, makes any warranty, express or implied, or cosumes any legal liability or responsibility for the accuracy, completeness, or any third party's use or the results of ach use of any information, apparatus, product, or process disclosed, or represents that its use would not infringe privately owned rights. Reference herein to any specific commercial product, process, or service by trade name, trademark, manufacturer, or otherwise, does not necessarily constitute or imply its endorsement, recommendation, or favoring by the United States Government or any agency thereof or its contractors or subcontractors. The views and cpinions of authors expressed herein do not necessarily state or reflect those of the United States Government or any esency thereot.

This report hes been reproduced from the best available copy. Aveleble in paper copy and microfiche.

Avaleble to the U.S. Department of Energy

and its contractors from

Office of Scientific and Technical Information

P.O. Box 62

Oak Ridge, TN 37831

(615) 576-8401

Avalable to the public from the U.S. Department of Commerce Netionel Technicel Information Service 5285 Port Royal Road

Springfield, VA 22161

(703) $487-4650$

Pinded in the United States of Anerice

DSCLM1.CHP (1-91) 


\section{DISCLAIMER}

Portions of this document may be illegible in electronic image products. Images are produced from the best available original document. 


\title{
Alkaline Chemistry of Transuranium Elements and Technetium and the Treatment of Alkaline Radioactive Wastes
}

\author{
V. F. Peretrukhin \\ V. P. Shilov
}

A. K. Pikaev

Institute of Physical Chemistry

Russian Academy of Sciences

Date Published

May 1995

Coordinated through

C. H. Delegard

Technical Liaison

Westinghouse Hanford Company

Prepared for the U.S. Department of Energy

Office of Evironmental Management, EM-1

Office of Technology Development, EM-50

Office of Research and Development, EM-53

Efficient Separations and Processing

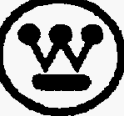

Westinghouse

P.O Box 1970

Hanford Company Richland, Washington

Hanford Operations and Engineering Contractor for the

U.S. Department of Energy under Contract DE-AC06-87RL10930

Approved for Public Release 


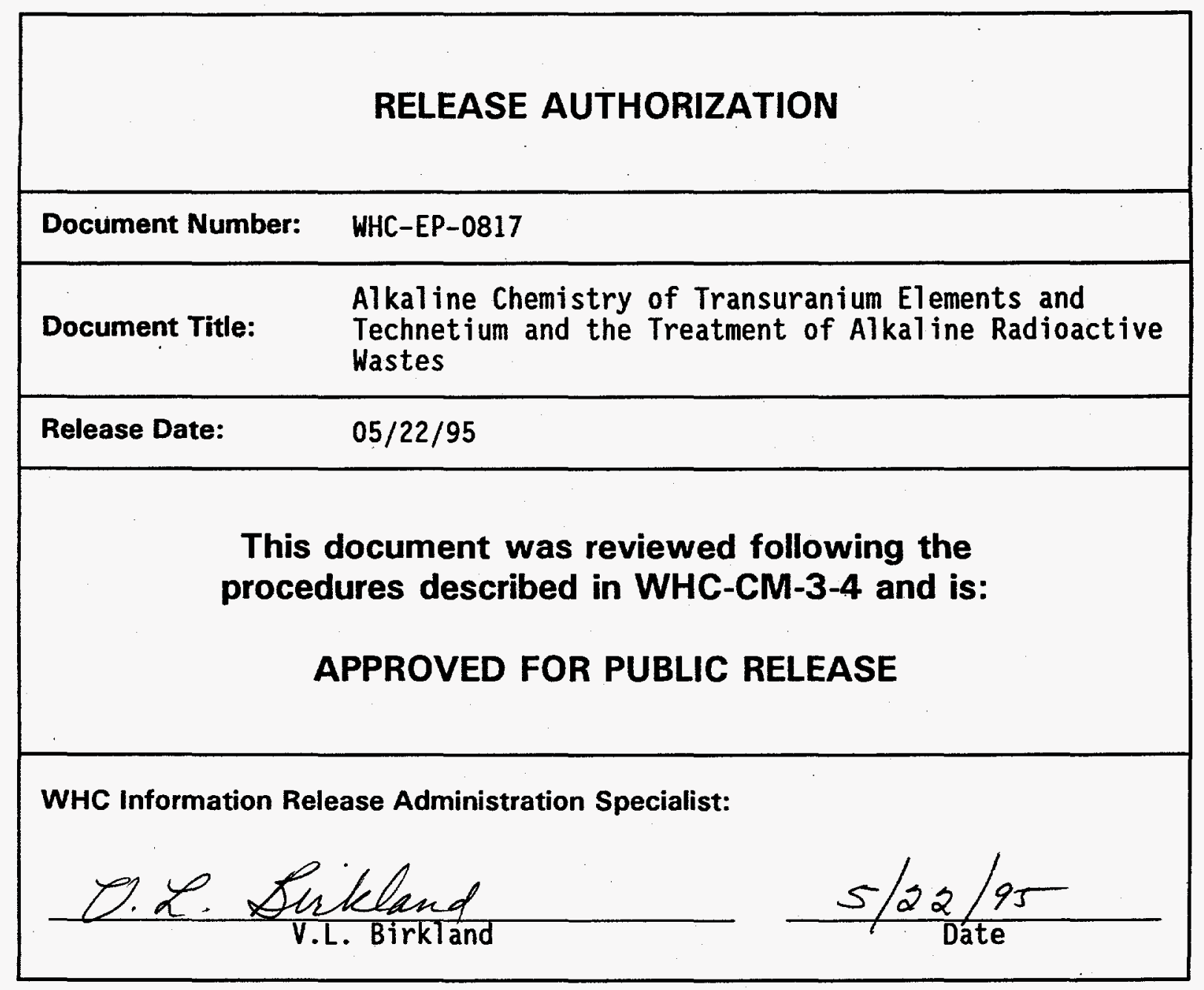

A-6001-400.2 (09/94) WEF256 


\section{CONTENTS}

1.0 INTRODUCTION $\ldots \ldots \ldots \ldots \ldots \ldots \ldots \ldots \ldots \ldots \ldots \ldots \ldots \ldots \ldots \ldots \ldots .11$

1.1 REFERENCES . . . . . . . . . . . . . . . . .

2.0 OXIDATION STATES OF TRANSURANIUM ELEMENTS AND

TECHNETIUM AND THEIR THERMODYNAMIC STABILITY

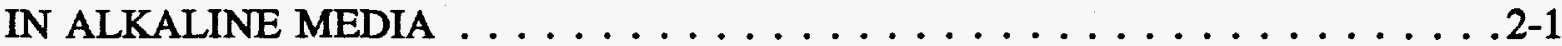

2.1 INTRODUCTION. RELEVANCE OF THERMODYNAMIC STABILITY

OF THE ELEMENTS IN SOLUTION TO THEIR

OXIDATION POTENTIALS . . . . . . . . . . . . . . . 2-1

2.2 OXIDATION POTENTIALS AND STABILITY OF TRANSURANIUM

ELEMENTS AND TECHNETIUM IN ALKALINE MEDIA $\ldots \ldots \ldots \ldots .2-1$

2.3 $\mathrm{Pu}(\mathrm{V}) / \mathrm{Pu}(\mathrm{IV})$ OXIDATION POTENTIAL AND STABILITY

OF Pu(V) AND Pu(IV) IN ALKALINE MEDIA . . . . . . . . . . . 2-7

2.4 OXIDATION POTENTIALS AND STABILITY OF Np, Pu

AND Am IN HIGHER OXIDATION STATES . . . . . . . . 2-8

2.5 OXIDATION POTENTIALS AND STABILITY OF

TECHNETIUM IONS IN ALKALINE MEDIA $\ldots \ldots \ldots \ldots . \ldots . . .17$

2.6 SOLUBILITY OF TRU HYDROXIDES AND

SPECIATION IN ALKALINE MEDIA . . . . . . . . . . . . . . 2-18

2.7 REFERENCES . . . . . . . . . . . . . . . . . . 2-27

3.0 REDOX REACTIONS OF ACTINIDES AND TECHNETIUM

IN ALKALINE MEDIA AND PREPARATION OF ACTINIDES

IN SELECTED OXIDATION STATES $\ldots \ldots \ldots \ldots \ldots \ldots \ldots \ldots$. $\ldots \ldots \ldots$

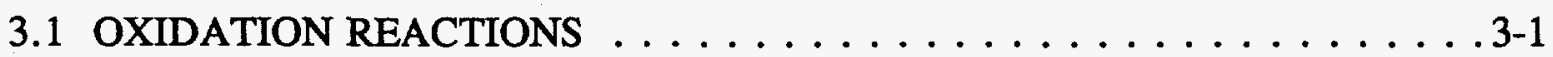

3.1 .1 Oxidation by Ozone . . . . . . . . . . . . . . . . . 3-1

3.1.2 Disproportionation of Neptunium(VI) and Americium(VI) . . . . 3-4

3.1 .3 Oxidation by Persulfate $\ldots \ldots \ldots \ldots \ldots \ldots \ldots \ldots \ldots \ldots \ldots$

3.1 .4 Oxidation by Hypobromite $\ldots \ldots \ldots \ldots \ldots \ldots \ldots$. . . . . . . . . .

3.1 .5 Oxidation by Hypochlorite $\ldots \ldots \ldots \ldots \ldots \ldots \ldots$. . . . . . . . .

3.1 .6 Oxidation by Ferricyanide . . . . . . . . . . . . . 3-14

3.1 .7 Oxidation by Xenon Compounds $\ldots \ldots \ldots \ldots \ldots \ldots \ldots \ldots \ldots$

3.1 .8 Oxidation by Silver Oxides . . . . . . . . . . . . 3-18

3.1 .9 Oxidation by Permanganate $\ldots \ldots \ldots \ldots \ldots \ldots \ldots \ldots$. . . . . . . . .

3.1 .10 Other Oxidation Processes $\ldots \ldots \ldots \ldots \ldots \ldots$. . . . . . . . . . .

3.2 REDUCTION REACTIONS . . . . . . . . . . . . . . . . . . 3-22

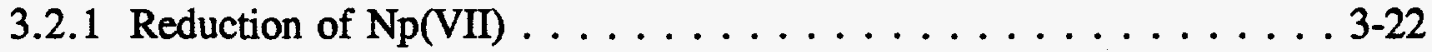

3.2.2 Kinetics of Pu(VII) Reduction by Water . . . . . . . . 3-22

3.2 .3 Reduction of $\mathrm{Np}$ (VII) by Sulfite $\ldots \ldots \ldots \ldots \ldots \ldots \ldots \ldots \ldots \ldots \ldots$

3.2.4 Reduction of $\mathrm{Np}$ (VII) by Iodide $\ldots \ldots \ldots \ldots \ldots \ldots \ldots . . \ldots \ldots$

3.2.5 Reduction of Pu(VII) by Iodide . . . . . . . . . . . . . . 3-27

3.2.6 Reduction of Pu(VII) by Iodate $\ldots \ldots \ldots \ldots \ldots \ldots \ldots \ldots . . \ldots \ldots$ 
CONTENTS (Continued)

3.2.7 Reduction of $\mathrm{Np}(\mathrm{VII})$ and $\mathrm{Pu}(\mathrm{VII})$ by Organic Compounds . . . . 3-29

3.2.8 List of Methods for the Preparation of

Actinides in Selected Oxidation States . . . . . . . . . . 3-31

3.3 REFERENCES . . . . . . . . . . . . . . . . . 3-34

4.0 ELECTROCHEMICAL REACTIONS OF ACTINIDES

AND TECHNETIUM IN ALKALINE MEDIA . . . . . . . . . . . . . 4-1

4.1 MECHANISM OF ELECTROCHEMICAL REACTIONS

OF ACTINIDES IN ALKALINE MEDIA . . . . . . . . . . . . 4-1

4.2 ELECTROCHEMICAL PREPARATION OF An(VII), An(VI)

AND An(V) $(\mathrm{An}=\mathrm{Np}, \mathrm{Pu}, \mathrm{Am})$ ALKALINE SOLUTIONS . . . . . . 4-3

4.3 ELECTROCHEMICAL METHODS OF DETERMINATION OF

ACTINIDES AND TECHNETIUM IN ALKALINE MEDIA $\ldots \ldots \ldots . .4-6$

4.4 REFERENCES . . . . . . . . . . . . . . . . . . 4-8

5.0 RADIATION CHEMISTRY OF ACTINIDES AND TECHNETIUM

IN CARBONATE AND ALKALINE SOLUTIONS $\ldots \ldots \ldots \ldots \ldots \ldots \ldots$. . . . . .

5.1 REACTIVITY OF ACTINIDE IONS TOWARDS WATER RADIOLYSIS

PRODUCTS AND OTHER FREE RADICALS $\ldots \ldots \ldots \ldots \ldots \ldots \ldots .5-4$

5.1 .1 Carbonate Medium . . . . . . . . . . . . . 5-4

5.1 .2 Alkaline Medium . . . . . . . . . . . . . . 5-8

$5.2 \gamma$-RADIOLYSIS OF ALKALINE SOLUTIONS OF

NEPTUNIUM AND PLUTONIUM IONS . . . . . . . . . . 5-23

5.2.1 Radiation-Induced Oxidation of $\mathrm{Np}(\mathrm{VI})$

Ions in Alkaline Solutions . . . . . . . . . . . . . . . 5-23

5.2.2 Radiation-Induced Reduction of $\mathrm{Np}$ (VII)

Ions in Alkaline Solutions . . . . . . . . . . . . . . . . 5-25

5.2.3 Radiation-Induced Oxidation of $\mathrm{Np}(\mathrm{VI})$ in Alkaline

Solutions Containing Persulfate, Periodate,

Hypobromite, or Perbromate . . . . . . . . . . . . . 5-26

5.2.4 Radiolysis of Carbonate-Alkaline Solutions of $\mathrm{Np}(\mathrm{VI}) \ldots \ldots \ldots$ 5-30

$5.2 .5 \gamma$-Radiolysis of Alkaline Solutions of Plutonium Ions $\ldots \ldots \ldots 5-32$

$5.3 \alpha$-RADIOLYSIS OF AMERICIUM IONS IN CARBONATE MEDIA $\ldots . .5$ 5-34

$5.4 \alpha$-RADIOLYSIS OF PLUTONIUM HYDROXIDES IN

ALKALINE MEDIA . . . . . . . . . . . . . . . 5-35

5.5 RADIOLYSIS OF ALKALINE SOLUTIONS OF TECHNETIUM IONS $\ldots$ 5-38

5.6 REFERENCES . . . . . . . . . . . . . . . . 5-41

6.0 METHODS OF ISOLATION OF ACTINIDES AND TECHNETIUM

FROM ALKALINE MEDIA WITHOUT ACIDIFICATION $\ldots \ldots \ldots \ldots \ldots$. . . .

6.1 COPRECIPITATION $\ldots \ldots \ldots \ldots \ldots \ldots \ldots \ldots \ldots \ldots \ldots \ldots \ldots$

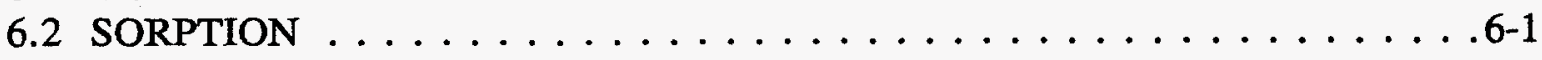




\section{CONTENTS (Continued)}

6.3 EXTRACTION . . . . . . . . . . . . . . . . . . . .6-4

6.3 .1 Extraction by Aliquat-336 ..............6.8

6.3.2 Extraction by Amines $\ldots \ldots \ldots \ldots \ldots \ldots \ldots \ldots$ 6-10

6.3.3 Extraction by Alkylpyrocatechols $\ldots \ldots \ldots \ldots \ldots \ldots \ldots$. $\ldots \ldots$

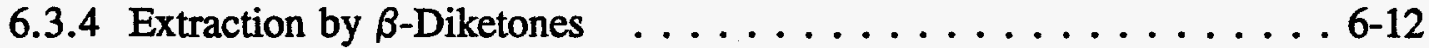

6.3.5 Extraction by Alkylaminoalcohols and Alkylphenols . . . . . . 6-13

6.3.6 Extraction of Technetium . . . . . . . . . . . . . 6-13

6.4 ELECTROCHEMICAL METHODS OF ACTINIDE AND TECHNETIUM

ISOLATION FROM ALKALINE SOLUTIONS . . . . . . . . . . . 6-15

6.4.1 Electrodeposition of Actinides and Technetium and Their

Cementation by Metals from Alkaline Solutions . . . . . . . . 6-15

6.4.2 Electrochemical Denitration of Alkaline Waste . . . . . . . 6-16

6.5 REFERENCES . . . . . . . . . . . . . . . . . 6-17

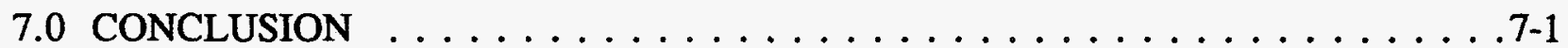

7.1 ACKNOWLEDGEMENT $\ldots \ldots \ldots \ldots \ldots \ldots \ldots \ldots \ldots \ldots \ldots \ldots \ldots .2$ 


\section{LIST OF FIGURES}

2-1 Oxidation Potentials Scheme of Actinides in $1 \mathrm{M} \mathrm{HClO}_{4}$ and $1 \mathrm{M} \mathrm{NaOH}$ Media (in Volts vs. Standard Hydrogen Electrode) $\ldots \ldots \ldots$. . . 2-6

2-2 Pu Oxidation Potentials in $1 \mathrm{M} \mathrm{HClO}_{4}$ and in $1 \mathrm{M} \mathrm{NaOH} \ldots \ldots \ldots \ldots$ 2-9

2-3 Redox Potentials of Actinides in Acidic and Alkaline Solutions . . . . . . . . 2-10

2-4 Dependence of Actinide Formal Potentials on Alkali Concentration . . . . . . . 2-12

4-1 Voltametry of $\mathrm{U}(\mathrm{VI}), \mathrm{Pu}(\mathrm{VI})$ and $\mathrm{Pu}(\mathrm{V})$ in $1 \mathrm{M} \mathrm{NaOH} \ldots \ldots . \ldots .7$

6-1 Extraction of Actinides from Alkaline Solutions . . . . . . . . . . 6-10

6-2 Extraction of Am(III) and Eu(III) from Alkaline Solutions with DOP $([4(\alpha, \alpha)$ dioctylethyl] pyrocatechol).

0.4 M DOP Solution in Toluene 


\section{LIST OF TABLES}

2-1 Formal Potentials for the Actinide Redox Couples, Measured vs. NHE . . . . . . 2-2

2-2 $\mathrm{Me} / \mathrm{Np}$ Ratios in Solid Np(V) Compounds, Precipitated From Alkaline Solutions of Different Concentrations . . . . . . . . . . . . . . . . . . . 2-13

2-3 Formal Oxidation Potential for Technetium Redox Couples in Acidic (Spitsyn and Kuzina 1981) and Alkaline (Founta et al. 1987; and Deutsch et al. 1978) Media . . . . . . . . . . . . . . . . . . 2-18

2-4 Selected Properties of An(III) Hydroxides . . . . . . . . . . . . . . 2-20

2-5 Values of Solubility of Actinide (IV) Hydroxides in Different Media and their Solubility Products . . . . . . . . . . . . . . 2-22

2-6 Solubility Products and Hydrolysis Constants of An(V) . . . . . . . . . . . 2-24

2-7 Solubilities of $\mathrm{Np}(\mathrm{V})$ in Different Basic Solutions $\ldots \ldots \ldots \ldots \ldots \ldots . \ldots \ldots$

2-8 Solubility Products of An(VI) Hydroxides . . . . . . . . . . . . . 2-26

2-9 The Solubility of Plutonium(VI) Hydroxides in Alkaline Solutions of Different Concentrations

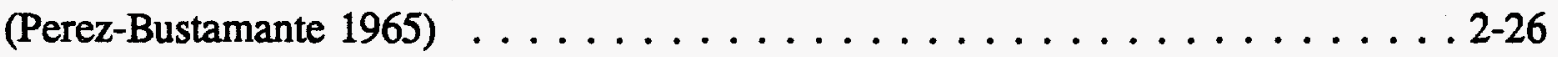

3-1 Disproportionation of $\mathrm{Np}(\mathrm{VI})$ in $\mathrm{NaOH}$ Solutions

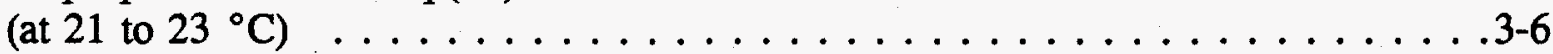

3-2 Disproportionation of $\mathrm{Am}(\mathrm{VI})$ in $\mathrm{NaOH}$ Solutions

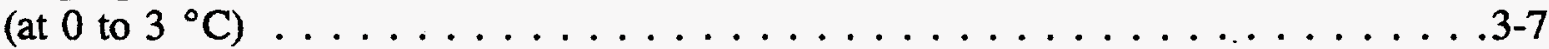

3-3 Kinetic Parameters of Np(VI) Oxidation at Different Concentrations of $\mathrm{S}_{2} \mathrm{O}_{8}^{2-}\left([\mathrm{Np}(\mathrm{VI})]_{\mathrm{o}}=2.3 \times 10^{-4} \mathrm{M}\right.$; $\left.\mu=2.0 \mathrm{M} ;\left[\mathrm{OH}^{-}\right]=0.2 \mathrm{M}, 60^{\circ} \mathrm{C}\right) \ldots \ldots \ldots \ldots \ldots \ldots \ldots \ldots \ldots \ldots . \ldots \ldots$

3-4 The Influence of Experimental Conditions on the Np(VI) Oxidation Rate by Hypobromite in the Presence of $\mathrm{Co}$ (II) Salt $([\mathrm{NaOH}]=0.5 \mathrm{M})$

3-5 The Equilibrium Constants $\mathrm{K}_{20}$ and the Rate Constants $\mathrm{k}$ for $\mathrm{Np}(\mathrm{VI})$ Oxidation by $\mathrm{Fe}(\mathrm{CN})_{6}^{3-}\left([\mathrm{MeOH}]=4 \mathrm{M}, 10^{\circ} \mathrm{C}\right) \ldots \ldots . . \ldots 3-15$ 


\section{LIST OF TABLES (Continued)}

3-6 Rate Constants for $\mathrm{Np}(\mathrm{VI})$ Oxidation by $\mathrm{Fe}(\mathrm{CN})_{6}^{3-}$ in $\mathrm{KOH}$ Solutions $\left([\mathrm{Np}(\mathrm{VI})]_{\mathrm{o}}=1.26 \times 10^{-4} \mathrm{M}, 10^{\circ} \mathrm{C}\right) \ldots \ldots \ldots . \ldots \ldots .16$

3-7 The Effect of $\mathrm{KOH}$ and AgO Concentrations on the $\mathrm{Np}$ (VII)

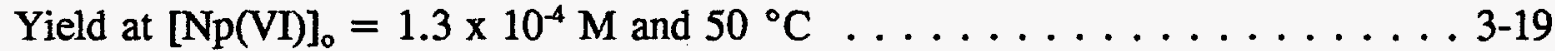

3-8 Time, in Minutes, for 50\% Reduction of $2.5 \times 10^{4} \mathrm{M} \mathrm{Np}$ (VII) with Different Compounds

3-9 Influence of Experimental Conditions on $\mathrm{Np}$ (VII) Reduction Rate by Sulfite (Ionic Strength $0.7 \mathrm{M}$ with $\mathrm{NaOH}$ and $\mathrm{NaNO}_{3}$ ) . . . . . 3-26

3-10 Kinetic Parameters for Np(VII) Reduction by Organic Compounds ....................... . . . . . . . .

3-11 Influence of the Nature of the Alcohol on the Kinetics of Pu(VII) Reduction (Tananaev 1992) .

3-12 Methods for the Preparation of Actinides in Selected Oxidation States in Alkaline Media . . . . . . . . . . . . . . 3-31

4-1 Current Density (i) and Current Efficiency (k) for $\mathrm{Np}$ (VII) and Pu(VII) Alkaline Solution Preparation Using Different Anodes at $25^{\circ} \mathrm{C}$

5-1 The Yields of Primary Products of Water Radiolysis in Bulk Solution for ${ }^{60} \mathrm{Co} \gamma$-Rays and Fast Electrons with Energies of $1 \mathrm{MeV}$ and Higher (Pikaev 1986) . . . . . . . . . . 5-1

5-2 The Yields of Primary Products of Water Radiolysis

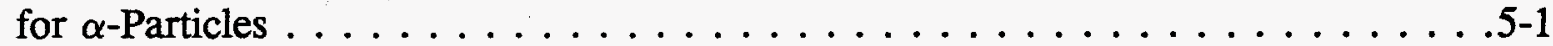

5-3 Rate Constants (k) of $\mathrm{e}_{\mathrm{aq}}^{-}$Reactions with Actinide Ions in Carbonate Solutions

5-4 The Evaluation of $k_{0}$ and $k_{\text {dif }}$ for Reactions of Carbonate Complexes of Neptunium with $\mathrm{e}_{\mathrm{aq}}^{-}$

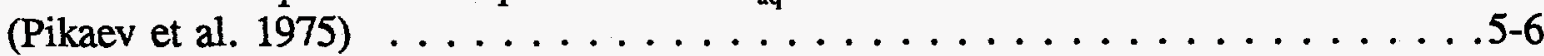

5-5 The Rate Constants of Reactions of $\mathrm{CO}_{3}^{-}$with Actinide Ions $\ldots \ldots \ldots$. . . . . . 


\section{LIST OF TABLES (Continued)}

5-6 Rate Constants of Reactions of $\mathrm{e}_{\mathrm{aq}}^{-}$with Neptunium Ions (Pikaev et al. 1973; Pikaev et al. 1976) . . . . . . . . . . . . 5-11

5-7 Influence of the Medium on the Rate Constants of Reactions Between $e_{\mathrm{aq}}^{-}$and Plutonium Ions . . . . . . . . . . . 5-13

5-8 Rate Constants of Reactions Between $\mathrm{Np}(\mathrm{VI})$ and $\mathrm{O}^{-}$at Different Concentrations of LiOH (Pikaev and Shilov 1978) . . . . . . . 5-16

5-9 Rate Constants of Reaction Between $\mathrm{Np}(\mathrm{VI})$ and $\mathrm{O}^{-}$at Different $\mathrm{NaOH}$ Concentrations . . . . . . . . . . . . . 5-16

5-10 Rate Constants of The Reaction Between $\mathrm{Np}(\mathrm{VI})$ and $\mathrm{O}_{3}^{-} \ldots \ldots$. . . . . . 5-20

5-11 The Rate Constants of Reaction Between $\mathrm{Np}(\mathrm{V})$ and $\mathrm{CO}_{3}^{-} \ldots \ldots \ldots \ldots$. . . . . .

5-12 The Rate Constants of Reaction Between $\mathrm{Np}(\mathrm{VII})$ and $\mathrm{Np}(\mathrm{V}) \ldots \ldots \ldots$. . . . 5-24

5-13 The Dependence of G[Np(VII)] on Concentration of Alkali $\left(\left[\mathrm{K}_{2} \mathrm{~S}_{2} \mathrm{O}_{8}\right]_{0}=0.02 \mathrm{M},[\mathrm{Np}(\mathrm{VI})]_{\mathrm{o}}=2.1 \times 10^{-4} \mathrm{M} \ldots \ldots \ldots \ldots \ldots \ldots \ldots\right.$

5-14 The Influence of the Solution Composition on G[Np(VII)] (Shilov et al. 1979 and Gusev et al. 1974)

5-15 The Influence of Solution Composition on $\mathrm{Np}$ (VII)

Yield $\left([\mathrm{Np}(\mathrm{VI})]_{0}=2.4 \times 10^{-4} \mathrm{M}\right.$, Dose Rate $=9.17 \times 10^{-2} \mathrm{~Gy} \mathrm{~s}^{-1}$ )

5-16 Nuclide Composition for Plutonium Used (Delegard 1987) and Nuclide Characteristics (Gorbachev et al. 1975)

5-17 The Influence of the $\mathrm{NaOH}$ Concentration on the Yield of the $\mathrm{Pu}(\mathrm{V})$ Reduction

5-18 Initial Yields of the $\mathrm{Pu}(\mathrm{VI})$ Reduction $\left([\mathrm{Pu}(\mathrm{VI})]_{\mathrm{o}}=4.4 \times 10^{-3} \mathrm{M}\right)($ Delegard 1987$) \ldots \ldots \ldots \ldots \ldots \ldots \ldots \ldots$

5-19 Molar Extinction Coefficients $(\epsilon)$ of $\mathrm{Tc}(\mathrm{VI})$ Ions in Aqueous Solutions

5-20 Rate Constants of Reactions in Irradiated Solutions of $\mathrm{TcO}_{4}^{-} \ldots \ldots \ldots$. . . 5-40 


\section{LIST OF TABLES (Continued)}

6-1 The Distribution Coefficients $\left(\mathrm{K}_{\mathrm{d}}\right)$ of $\mathrm{TcO}_{4}^{-}$Upon Sorption on the Anion Exchange Resin Dowex-1 from 0.25 M NaOH (Rimshaw and Malling 1961) . . . . . . . . . . . . . 6-5

6-2 Distribution Coefficients $\left(\mathrm{K}_{\mathrm{d}}\right)$ of Actinides(V), Actinides(VI), and Technetium(VII) for $\mathrm{NaOH}$ Solutions and the Anion Exchange Resin VP-1AP . . . . . . . . . . . . . . . . . . .6-5

6-3 The Distribution Coefficients (D) of Neptunium for the System Phenolic Extractant - 0.5 M NaOH (Karalova et al. 1990a) . . . . . . . . . . . . . . . . . . . . . . . . .6-7

6-4 Extraction of $\mathrm{Tc}(\mathrm{VII})$ from Solutions of $\mathrm{NaOH} \ldots \ldots \ldots \ldots \ldots \ldots . \ldots \ldots$ 
Cited Journals Published in the Russian Language and Their Availability in English Translation

\begin{tabular}{|c|c|c|c|}
\hline $\begin{array}{c}\text { Russian Journal } \\
\text { Abbreviation }\end{array}$ & $\begin{array}{l}\text { Full Name of the } \\
\text { Russian Journal }\end{array}$ & $\begin{array}{c}\text { Translation of the } \\
\text { Russian Journal Title }\end{array}$ & $\begin{array}{l}\text { English Language } \\
\text { Version of the } \\
\text { Russian Journal }\end{array}$ \\
\hline Atom. Energ. & Atomnaya Energiya & Atomic Energy & $\begin{array}{l}\text { Sov. At. Energy } \\
\text { (Engl. Transl.) }\end{array}$ \\
\hline $\begin{array}{l}\text { Dokl. Akad. Nauk } \\
\text { SSSR }\end{array}$ & $\begin{array}{l}\text { Doklady Akademii } \\
\text { Nauk SSSR }\end{array}$ & $\begin{array}{l}\text { Proceedings of the } \\
\text { Academy of Sciences of } \\
\text { the USSR }\end{array}$ & $\begin{array}{l}\text { Dokl. Chem. (Engl. } \\
\text { Transl.) } \\
\text { or } \\
\text { Dokl. Phys. Chem. } \\
\text { (Engl. Transl.) }\end{array}$ \\
\hline $\begin{array}{l}\text { Izv. Sib. Otd. Akad. } \\
\text { Nauk, Ser. Khim. }\end{array}$ & $\begin{array}{l}\text { Izvestiya Sibirskogo } \\
\text { Otdeleniya Akademii } \\
\text { Nauk, Seriya } \\
\text { Khimicheskikh }\end{array}$ & $\begin{array}{l}\text { Proceedings of the } \\
\text { Siberian Department of } \\
\text { the Academy of Sciences } \\
\text { of the USSR, Series on } \\
\text { Chemical Sciences }\end{array}$ & $\begin{array}{l}\text { Sib. Chem. J. (Engl. } \\
\text { Transl.) }\end{array}$ \\
\hline $\begin{array}{l}\text { Izv. Akad. Nauk, } \\
\text { Ser. Khim. }\end{array}$ & $\begin{array}{l}\text { Izvestiya Akademii } \\
\text { Nauk SSSR, Seriya } \\
\text { Khimicheskaya }\end{array}$ & $\begin{array}{l}\text { Proceedings of the } \\
\text { Academy of Sciences of } \\
\text { the USSR, Chemical } \\
\text { Series }\end{array}$ & $\begin{array}{l}\text { Bull. Acad. Sci. } \\
\text { USSR, Div. Chem. } \\
\text { Sci. (Engl. Transl.) }\end{array}$ \\
\hline Khim. Vys. Energ. & $\begin{array}{l}\text { Khimiya Vysokikh } \\
\text { Energii }\end{array}$ & High Energy Chemistry & $\begin{array}{l}\text { High Energy Chem. } \\
\text { (Engl. Transl.) }\end{array}$ \\
\hline Radiokhimiya & Radiokhimiya & Radiochemistry & $\begin{array}{l}\text { Sov. Radiochem. } \\
\text { (Engl. Transl.) } \\
\text { [through volume 34, } \\
\text { 1992] } \\
\text { Radiochemistry } \\
\text { (Engl. Transl.) } \\
\text { [since volume 35, } \\
\text { 1993] }\end{array}$ \\
\hline $\begin{array}{l}\text { Tr. Radievogo Inst., } \\
\text { Akad. Nauk SSSR }\end{array}$ & $\begin{array}{l}\text { Trudy Radievogo } \\
\text { Instituta, Akademii } \\
\text { Nauk SSSR }\end{array}$ & $\begin{array}{l}\text { Transactions of the } \\
\text { Radium Institute, } \\
\text { Academy of Sciences of } \\
\text { the USSR }\end{array}$ & $\begin{array}{l}\text { not available in } \\
\text { English }\end{array}$ \\
\hline Zh. Anal. Khim. & $\begin{array}{l}\text { Zhurnal } \\
\text { Analiticheskoi } \\
\text { Khimii }\end{array}$ & $\begin{array}{l}\text { Journal of Analytical } \\
\text { Chemistry }\end{array}$ & $\begin{array}{l}\text { J. Anal. Chem. } \\
\text { USSR (Engl. } \\
\text { Transl.) }\end{array}$ \\
\hline Zh. Neorg. Khim. & $\begin{array}{l}\text { Zhurnal } \\
\text { Neorganicheskoi } \\
\text { Khimii }\end{array}$ & $\begin{array}{l}\text { Journal of Inorganic } \\
\text { Chemistry }\end{array}$ & $\begin{array}{l}\text { Russ. J. Inorg. } \\
\text { Chem. (Engl. } \\
\text { Transl.) }\end{array}$ \\
\hline
\end{tabular}


This page intentionally left blank. 


\subsection{INTRODUCTION}

The chemistry of transuranium (TRU) elements neptunium ( $\mathrm{Np}$ ), plutonium $(\mathrm{Pu})$, americium $(\mathrm{Am})$, and curium $(\mathrm{Cm})$ in alkaline media is developed rather poorly when compared with knowledge in acid media. In addition, no literature survey exists devoted to the chemistry of TRU in alkaline media. However, some information is available in monographs (Seaborg et al. 1986; Krot et al. 1977; and Pikaev et al. 1983), a Los Alamos National Laboratory report (Marsh 1993) and numerous articles quoted in the present survey.

The main steps of spent fuel treatment take place in nitric acid media. Sodium hydroxide media are used for aluminum cladding dissolution and for high-level waste (HLW) storage in the form of sludge in tanks. Alkaline radioactive sludges exist in tanks in reprocessing plants worldwide. The sludges, accumulated during many years, must be transformed to safer forms (such as glass) for long-term storage. No technology currently is available to perform this transformation with alkaline sludges in any country. Additional information on the physical and chemical properties of TRU and fission products in alkaline media are required as a basis to undertake processing of this waste.

Initial information on the alkaline chemistry of TRU was obtained by the researchers of the Manhattan Project in the 1940s. They determined that TRU in oxidation states (III) to (VI) form sparingly soluble precipitates in alkaline media (Kraus 1949a, Kraus 1949b, and Connick et al. 1949). This information was further augmented in the 1950s and the beginning of the 1960s.

The heptavalent state of $\mathrm{Np}, \mathrm{Pu}$, and $\mathrm{Am}$ was discovered in 1967 to 1969 at the Institute of Physical Chemistry of the USSR Academy of Sciences (Krot and Gel'man 1967). The heptavalent TRU element compounds were determined to be stable and somewhat soluble in strongly alkaline media. This discovery increased scientific interest in the alkaline chemistry of TRU and new information about the fundamental physical and chemical properties of $\mathrm{Np}$, $\mathrm{Pu}$, and $\mathrm{Am}$ in alkaline media has been obtained in the laboratories of various countries.

Important conclusions regarding the thermodynamical and real stability of $\mathrm{Pu}(\mathrm{V})$ in alkaline solution and waste made by French, Russian, and American investigators (Bourges 1972, Peretrukhin and Alekseeva 1974; and Delegard 1987) have practical importance. However, few published papers exist devoted to the development of methods for the isolation of the TRU elements from alkaline wastes (Marsh 1993).

The goal of this survey is to generalize the known data on the fundamental physical-chemical properties of TRU and technetium (Tc), on the methods of their isolation, and to provide recommendations that will be useful for partitioning them from alkaline HLW media.

Unfortunately, several of the US national laboratories' reports on TRU alkaline chemistry are not available in Russia. In such cases, these papers are included, without evaluation, in the list of references. Note that the majority of the published research on the alkaline chemistry of TRU and Tc was conducted at the Institute of Physical Chemistry of the Russian Academy 
of Sciences. Therefore, the authors working in the Institute appreciated the opportunity to write this survey, which was sponsored by the U.S. Department of Energy (DOE) and coordinated by Westinghouse Hanford Company (WHC).

\subsection{REFERENCES}

Bourges J., 1972, Radiochim. Radioanal. Lett., 12, 111.

Delegard, C. H., 1987, Radiochimica Acta, 41, 11.

Connick, R. E., W. H. McVey, and G. E. Sheline, 1949, in The Transuranium Elements, G. T. Seaborg, J. J. Katz, and W. M. Manning, Eds., Natl. Nucl. En. Ser., Div. IV, Vol. 14B, Part I, p. 336, McGraw-Hill Book Company, Inc., New York, New York.

Kraus, K. A., 1949a, in The Transuranium Elements, G. T. Seaborg, J. J. Katz, and W. M. Manning, Eds., Nat. Nucl. En. Serv. Div. IV, Vol. 14B, Part I, p. 519, McGraw-Hill, New York, New York.

Kraus, K. A., 1949b, Ibid, p. 241.

Krot, N. N., and A. D. Gel'man, 1967, Dokl. Akad. Nauk SSSR, 177, 124.

Krot, N. N., A. D. Gel'man, M. P. Mefod'eva, V. P. Shilov, V. F. Peretrukhin, and V. I. Spitsyn, 1977, Semivalentnoe Sostoyanie Neptuniya, Plutoniya, Ameritsiya, Nauka, Moscow, USSR (in Russian). Available in English as Heptavalent States of Neptunium, Plutonium, and Americium, UCRL-Trans-11798, Lawrence Livermore National Laboratory, Livermore, California.

Marsh, S.F., 1993, Partitioning of HLW from Alkaline Solution, A Literature Survey, LA-12528, Los Alamos National Laboratory, Los Alamos, New Mexico.

Peretrukhin, V. F., and D. P. Alekseeva, 1974, Radiokhimiya, 16, 823.

Pikaev A. K., V. P. Shilov, and V. I. Spitsyn, 1983, Radioliz Vodnyh Rastvorov

Lantanidov $i$ Aktinidov, Nauka, Moscow, USSR (in Russian). Available in English as Radiolysis of Aqueous Solutions of Lanthanides and Actinides, 1985, AERE LBG-8501-002, Atomic Energy Research Establishment, Harwell, UK.

Seaborg, G. and J. Katz, and L. Morss, Eds. 1986, Chemistry of Actinide Elements, Chapman and Hall Ltd., London, UK, New York, New York. 


\subsection{OXIDATION STATES OF TRANSURANIUM ELEMENTS AND TECHNETIUM AND THEIR THERMODYNAMIC STABILITY IN ALKALINE MEDIA}

\subsection{INTRODUCTION. RELEVANCE OF THERMODYNAMIC STABILITY OF THE ELEMENTS IN SOLUTION TO THEIR OXIDATION POTENTIALS}

The thermodynamic stability of the oxidation state in aqueous solution is one of the important physical-chemical characteristics of an element. An element that is thermodynamically stable in a certain oxidation state does not undergo disproportionation reactions or redox reactions with water. Thus, values of the Gibbs free energy for such hypothetical (but, in practice, impossible) reactions should be positive $(\Delta G>0)$. The latter value is easily calculated using standard oxidation potentials in the solutions $\left(\mathrm{E}^{\circ}\right)$, according to the equation: $\Delta \mathrm{G}^{\circ}=-\mathrm{nF} \Delta \mathrm{E}^{\circ}$, where $\mathrm{n}$ is the number of the electrons involved to the redox process and $\mathrm{F}$ is the Faraday number. The usual way to estimate the direction of a disproportionation reaction is to estimate the sign of $\Delta \mathrm{E}^{\circ}$ using the values of the neighbor couples' oxidation potentials. To determine the direction of redox reactions of the element of interest with water, the oxidation potential of the neighboring oxidation states are compared with the standard potentials of $\mathrm{H}_{2}$ or $\mathrm{O}_{2}$ evolution from water at a given $\mathrm{pH}$ value. Unfortunately, the values of the actinides' standard redox standard potentials in alkaline media are not currently reported. Only the values of formal redox potentials for actinides in different media have been determined. The formal potentials were used in all the papers quoted in the present review. Formal potentials differ from standard potentials by assuming that the unknown activity coefficients of the elements of interest are equal to 1 . In general, this uncertainty of formal potentials' values does not affect the estimation of the redox reactions' directions.

\subsection{OXIDATION POTENTIALS AND STABILITY OF TRANSURANIUM ELEMENTS AND TECHNETIUM IN ALKALINE MEDIA}

The oxidation states $(+2$ to +7$)$ have been reported for $\mathrm{Np}, \mathrm{Pu}, \mathrm{Am}$, and $\mathrm{Tc}$ in aqueous solutions. The oxidation state $(+2)$, reported for $\mathrm{Np}, \mathrm{Pu}$, and $\mathrm{Am}$ in acidic media, is unstable and has not been detected in alkaline solutions. The thermodynamic and experimental stability of each oxidation state can change sharply with an increase of solution $\mathrm{pH}$. The general regularity, characteristic for actinide and technetium ions, means that the highest oxidation states $(+7$ to +5$)$ are more stable in alkaline than in acidic media, while the reverse effect is noticed for lower oxidation states $(+3$ and +4$)$ [excluding Am(IV)].

The data on the oxidation potentials of TRU elements in $1 \mathrm{M} \mathrm{HClO}_{4}$ and alkaline media are summarized in Table 2-1. Clearly, in alkaline solution, more is known about higher actinide oxidation states $(+7,+6,+5)$ than about lower states $(+3,+4)$. This is because actinide hydroxides and salts in oxidation states VII, VI, and V have higher solubilities than analogous compounds in oxidation states IV and III. The low solubility of actinide(IV) and actinide(III) hydroxides in alkaline media makes the majority of conventional experimental 
techniques inapplicable to direct oxidation potential measurements. Figure 2-1 presents the scheme of $\mathrm{Np}, \mathrm{Pu}$, and Am oxidation potentials in $1 \mathrm{M} \mathrm{HClO}_{4}$ and in $1 \mathrm{M} \mathrm{NaOH}$. The data for plotting this scheme have been taken from Table 2-1. The presented graph illustrates the trend of actinide oxidation potentials to shift towards lower values as the solution acidity decreases. When the acidity is decreased from $1 \mathrm{M} \mathrm{HClO}_{4}$ to $1 \mathrm{M} \mathrm{NaOH}$, about $-1.9 \mathrm{~V}$ shift in $\mathrm{Np}, \mathrm{Pu}$, and $\mathrm{Am}$ (IV)/(III) oxidation potentials occurs. In accordance with the values of their oxidation potentials, $\mathrm{Np}$ (III) and $\mathrm{Pu}$ (III) hydroxides are able to reduce water molecules, with hydrogen evolution, in alkaline media. The data on the oxidation potentials of $\mathrm{Np}$ and Am (Table 2-1 and Figure 2-1) do not differ from those reported in Martinot and Fuger (1985) and Katz et al. (1986a). In case of plutonium, however, sharp contradictions between the $\mathrm{Pu}(\mathrm{V}) / \mathrm{Pu}(\mathrm{IV})$ oxidation potential values reported by different authors are found. Therefore the $\mathrm{Pu}(\mathrm{V}) / \mathrm{Pu}(\mathrm{IV})$ redox equilibrium in alkaline media needs more detailed examination.

Table 2-1. Formal Potentials for the Actinide Redox Couples, Measured vs. NHE.

\begin{tabular}{|c|c|c|c|c|c|c|c|c|}
\hline Media & $\mathrm{VII} / \mathrm{VI}$ & $\mathrm{VI} / \mathrm{V}$ & VI/IV & V/IV & IV/III & III/II & III/0 & II/0 \\
\hline \multicolumn{9}{|c|}{ Uranium } \\
\hline $1 \mathrm{M} \mathrm{HClO}_{4}$ & & $\begin{array}{l}0.063 \\
{[1,2]}\end{array}$ & $\begin{array}{c}0.321 \\
{[1]}\end{array}$ & $\begin{array}{c}0.58 \\
{[1]}\end{array}$ & $\begin{array}{c}-0.631 \\
{[1,2]}\end{array}$ & $\begin{array}{c}-4.7 \\
{[3]}\end{array}$ & -1.66 & $\begin{array}{c}-0.1 \\
{[3]}\end{array}$ \\
\hline $\begin{array}{c}0.05 \mathrm{M} \\
\mathrm{Na}_{2} \mathrm{CO}_{3}\end{array}$ & & $\begin{array}{c}-0.671 \\
{[4]}\end{array}$ & & & & & & \\
\hline $1 \mathrm{M} \mathrm{K}_{2} \mathrm{CO}_{3}$ & & $\begin{array}{c}-0.6 \\
{[5]}\end{array}$ & & $\begin{array}{l}0.0 \\
{[5]}\end{array}$ & $\begin{array}{c}-2.03 \\
{[5]}\end{array}$ & & & \\
\hline $1 \mathrm{M} \mathrm{NaOH}$ & & $\begin{array}{c}-0.65 \\
{[6]}\end{array}$ & $\begin{array}{c}-0.3 \\
{[3]}\end{array}$ & & $\begin{array}{c}-2.6 \\
{[3]}\end{array}$ & & $\begin{array}{c}-2.10 \\
{[3]}\end{array}$ & \\
\hline \multicolumn{9}{|c|}{ Neptunium } \\
\hline $1 \mathrm{M} \mathrm{HClO}_{4}$ & $\begin{array}{c}2.04 \\
{[7]}\end{array}$ & $\begin{array}{l}1.137 \\
{[1,2]}\end{array}$ & & $\begin{array}{l}0.739 \\
{[1,2]}\end{array}$ & $\begin{array}{l}0.155 \\
{[1,2]}\end{array}$ & $\begin{array}{c}-4.7 \\
{[2,3]}\end{array}$ & $\begin{array}{l}-1.79 \\
{[2,3]}\end{array}$ & $\begin{array}{r}-0.3 \\
{[2,3]}\end{array}$ \\
\hline $\begin{array}{l}0.05 \mathrm{M} \\
\mathrm{Na}_{2} \mathrm{CO}_{3}\end{array}$ & & $\begin{array}{c}0.445 \\
{[4]}\end{array}$ & & & & & & \\
\hline $1 \mathrm{M} \mathrm{K}_{2} \mathrm{CO}_{3}$ & & $\begin{array}{c}0.44 \\
{[8]}\end{array}$ & & $\begin{array}{l}0.1 \\
{[5]}\end{array}$ & $\begin{array}{c}-1.32 \\
{[5]}\end{array}$ & & & \\
\hline $1 \mathrm{M} \mathrm{NaOH}$ & $\begin{array}{c}0.582 \\
{[9]}\end{array}$ & $\begin{array}{l}0.18 \\
{[11]}\end{array}$ & & & & & & \\
\hline $1 \mathrm{M} \mathrm{NaOH}$ & $\begin{array}{c}0.587 \\
{[10]}\end{array}$ & $\begin{array}{l}0.11 \\
{[12]}\end{array}$ & & $\begin{array}{c}-0.95 \\
{[13]}\end{array}$ & $\begin{array}{l}-1.8 \\
{[13]}\end{array}$ & & $\begin{array}{c}-2.32 \\
{[2]}\end{array}$ & \\
\hline $10 \mathrm{M} \mathrm{NaOH}$ & $\begin{array}{l}0.25 \\
{[13]}\end{array}$ & $\begin{array}{l}0.05 \\
{[13]}\end{array}$ & & $\begin{array}{l}-1.0 \\
{[13]}\end{array}$ & $\begin{array}{l}-2.0 \\
{[13]}\end{array}$ & & & \\
\hline $1 \mathrm{M} \mathrm{LiOH}$ & $\begin{array}{c}0.604 \\
{[14]}\end{array}$ & $\begin{array}{c}0.150 \\
{[14]}\end{array}$ & & & & & & \\
\hline
\end{tabular}


Table 2-1. Formal Potentials for the Actinide Redox Couples, Measured vs. NHE.

\begin{tabular}{|c|c|c|c|c|c|c|c|c|}
\hline Media & VIIVI & $\mathrm{VI} / \mathrm{V}$ & VI/IV & V/IV & IV/III & III/II & III/0 & II/0 \\
\hline \multicolumn{9}{|c|}{ Plutonium } \\
\hline $1 \mathrm{M} \mathrm{HClO}_{4}$ & $\begin{array}{r}\cong 2.3 \\
{[15]}\end{array}$ & $\begin{array}{c}0.916 \\
{[16]}\end{array}$ & $\begin{array}{c}1.043 \\
{[16]}\end{array}$ & $\begin{array}{c}1.170 \\
{[16]}\end{array}$ & $\begin{array}{c}0.982 \\
{[16]}\end{array}$ & $\begin{array}{c}-3.5 \\
{[3]}\end{array}$ & $\begin{array}{l}-2.0 \\
{[3]}\end{array}$ & $\begin{array}{c}-1.2 \\
{[3]}\end{array}$ \\
\hline $\begin{array}{c}0.05 \mathrm{M} \\
\mathrm{Na}_{2} \mathrm{CO}_{3}\end{array}$ & $\begin{array}{c}0.334 \\
{[4]}\end{array}$ & & & & & & & \\
\hline $1 \mathrm{M} \mathrm{K}_{2} \mathrm{CO}_{3}$ & $\begin{array}{c}0.32 \\
{[8]}\end{array}$ & & & $\begin{array}{l}0.6 \\
{[5]}\end{array}$ & $\begin{array}{c}-0.495 \\
{[5]}\end{array}$ & & & \\
\hline $1 \mathrm{M} \mathrm{NaOH}$ & $\begin{array}{c}0.849 \\
{[17]}\end{array}$ & $\begin{array}{l}0.23 \\
{[18]}\end{array}$ & & $\begin{array}{l}0.76 \\
{[20]}\end{array}$ & $\begin{array}{c}-0.95 \\
{[19]}\end{array}$ & & $\begin{array}{c}-2.46 \\
{[3]}\end{array}$ & \\
\hline $1 \mathrm{M} \mathrm{NaOH}$ & & $\begin{array}{l}0.21 \\
{[19]}\end{array}$ & & $\begin{array}{l}0.86 \\
{[21]}\end{array}$ & $\begin{array}{c}-1.4 \\
{[3]}\end{array}$ & & & \\
\hline $1 \mathrm{M} \mathrm{NaOH}$ & - & & & $\begin{array}{c}-0.75 \\
{[19]}\end{array}$ & & & & \\
\hline $1 \mathrm{M} \mathrm{NaOH}$ & & & & $\begin{array}{l}0.9 \\
{[3]}\end{array}$ & & & & \\
\hline $4 \mathrm{M} \mathrm{NaOH}$ & & & & $\begin{array}{l}0.44 \\
{[18]}\end{array}$ & & & & \\
\hline $11 \mathrm{M} \mathrm{NaOH}$ & $\begin{array}{l}0.35 \\
{[19]}\end{array}$ & $\begin{array}{l}0.16 \\
{[19]}\end{array}$ & & $\begin{array}{c}-1.03 \\
{[19]}\end{array}$ & $\begin{array}{c}-1.34 \\
{[19]}\end{array}$ & & & \\
\hline
\end{tabular}


Table 2-1. Formal Potentials for the Actinide Redox Couples, Measured vs. NHE.

\begin{tabular}{|c|c|c|c|c|c|c|c|c|}
\hline Media & $\mathrm{VII} / \mathrm{VI}$ & $\mathrm{V} / \mathrm{V}$ & $\mathrm{V} / \mathrm{TV}$ & $\mathrm{V} / \mathrm{IV}$ & IV/III & $\pi / \pi$ & III/0 & $\pi / 0$ \\
\hline \multicolumn{9}{|c|}{ Americium } \\
\hline $1 \mathrm{M} \mathrm{HClO}_{4}$ & & $\begin{array}{l}1.60 \\
{[1,3]}\end{array}$ & & $\begin{array}{c}0.82 \\
{[3]}\end{array}$ & $\begin{array}{l}2.62 \\
{[3]}\end{array}$ & $\begin{array}{c}-2.3 \\
{[3]}\end{array}$ & $\begin{array}{c}-2.07 \\
{[3]}\end{array}$ & $\begin{array}{c}-1.95 \\
{[3]}\end{array}$ \\
\hline $1 \mathrm{M} \mathrm{Na}_{2} \mathrm{CO}_{3}$ & & $\begin{array}{l}0.9 \\
{[22]}\end{array}$ & & & & & & \\
\hline $\begin{array}{c}2 \mathrm{M} \\
\mathrm{NaHCO}_{3} \\
\mathrm{Na}_{2} \mathrm{CO}_{3} \\
\mathrm{pH}=9.7\end{array}$ & & & & & $\begin{array}{l}0.92 \\
{[23]}\end{array}$ & & & \\
\hline $\begin{array}{c}2 \mathrm{M} \\
\mathrm{NaHCO}_{3} \\
\mathrm{Na}_{2} \mathrm{CO}_{3} \\
\mathrm{pH}=10.0\end{array}$ & & $\begin{array}{l}0.93 \\
{[24]}\end{array}$ & & & $\begin{array}{c}0.89 \\
{[24,25]}\end{array}$ & & & \\
\hline $\begin{array}{c}2 \mathrm{M} \\
\mathrm{NaHCO}_{3} \\
\mathrm{Na}_{2} \mathrm{CO}_{3} \\
\mathrm{pH}=10.0\end{array}$ & & $\begin{array}{c}0.975 \\
{[26]}\end{array}$ & & & & & & \\
\hline $1 \mathrm{M} \mathrm{K}_{2} \mathrm{CO}_{3}$ & & $\begin{array}{l}0.9 \\
{[8]}\end{array}$ & & $\begin{array}{l}0.5 \\
{[5]}\end{array}$ & & & & \\
\hline $1 \mathrm{M} \mathrm{K}_{2} \mathrm{CO}_{3}$ & & $\begin{array}{l}0.86 \\
{[22]}\end{array}$ & & & & & & \\
\hline $\begin{array}{c}2.82 \mathrm{M} \\
\mathrm{KHCO}_{3} \\
\mathrm{~K}_{2} \mathrm{CO}_{3} \\
\mathrm{pH}=8.87\end{array}$ & & & & & $\begin{array}{l}0.93 \\
{[27]}\end{array}$ & & & \\
\hline $\begin{array}{c}2.82 \mathrm{M} \\
\mathrm{KHCO}_{3} \\
\mathrm{~K}_{2} \mathrm{CO}_{3} \\
\mathrm{pH}=11.2\end{array}$ & & & & & $\begin{array}{l}0.81 \\
{[27]}\end{array}$ & & & \\
\hline $1 \mathrm{M} \mathrm{NaOH}$ & $\begin{array}{l}1.05 \\
{[28]}\end{array}$ & $\begin{array}{l}0.65 \\
{[29]}\end{array}$ & & & & & & $\begin{array}{c}-2.53 \\
{[3]}\end{array}$ \\
\hline $1 \mathrm{M} \mathrm{NaOH}$ & & $\begin{array}{l}0.68 \\
{[30]}\end{array}$ & & $\begin{array}{c}0.25 \text { to } \\
0.50 \\
{[30]}\end{array}$ & $\begin{array}{l}<0.25 \\
{[30]}\end{array}$ & & & \\
\hline $10 \mathrm{M} \mathrm{NaOH}$ & & $\begin{array}{l}0.63 \\
{[30]}\end{array}$ & & $\begin{array}{c}0.17 \text { to } \\
0.50 \\
{[30]}\end{array}$ & $\begin{array}{l}<0.18 \\
{[30]}\end{array}$ & & & \\
\hline
\end{tabular}


Table 2-1. Formal Potentials for the Actinide Redox Couples, Measured vs. NHE.

\begin{tabular}{|c|c|c|c|c|c|c|c|c|}
\hline Media & VII/VI & $\mathrm{VU} / \mathrm{V}$ & VI/IV & $\mathrm{V} / \mathrm{IV}$ & IV/III & III/II & III/0 & II/0 \\
\hline \multicolumn{9}{|c|}{ Curium } \\
\hline $1 \mathrm{M} \mathrm{HClO}_{4}$ & $\begin{array}{c}2.7 \\
{[31,32]}\end{array}$ & $\begin{array}{c}1.5 \\
{[31,32]}\end{array}$ & & $\begin{array}{c}1.7 \\
{[31,32]}\end{array}$ & $\begin{array}{l}3.1 \\
{[3]}\end{array}$ & $\begin{array}{c}-3.7 \\
{[3]}\end{array}$ & $\begin{array}{c}-2.06 \\
{[3]}\end{array}$ & $\begin{array}{c}-1.2 \\
{[3]}\end{array}$ \\
\hline $1 \mathrm{M} \mathrm{K}_{2} \mathrm{CO}_{3}$ & & & & $\begin{array}{l}0.5 \\
{[5]}\end{array}$ & $\begin{array}{l}1.6 \\
{[5]}\end{array}$ & & & \\
\hline $1 \mathrm{M} \mathrm{NaOH}$ & & & & & $\begin{array}{l}0.7 \\
{[3]}\end{array}$ & & $\begin{array}{c}-2.53 \\
{[3]}\end{array}$ & \\
\hline
\end{tabular}

References:

[1] Martinot and Fuger 1985

[2] Katz et al. 1986a

[3] Katz et al. $1986 b$

[4] Mulac et al. 1984

[5] Fedoseev et al. 1979

[6] Musicas and Rousset 1971

[7] Musicas et al. 1974

[8] Simakin et al. 1974

[9] Zielen and Cohen 1970

[10] Shilov et al. 1970

[11] Simakin et al. 1973

[12] Peretrukhin and Alekseeva 1974a

[13] Peretrukhin and Spitsyn 1982

[14] Ermakov et al. 1977b

[15] Krot et al. 1977

[16] Rabideau et al. 1958

[17] Peretrukhin et al. 1972

[18] Bourges 1972

[19] Peretrukhin and Alekseeva 1974b

[20] Kraus 1949

[21] Connick 1955

[22] Simakin 1977

[23] Hobart et al. 1982

[24] Frenkel et al. 1985a

[25] Frenkel et al. 1985b

[26] Bourges et al. 1983

[27] Berger et al. 1988

[28] Nikolayevsky et al. 1975a

[29] Nikolayevsky et al. 1974

[30] Peretrukhin et al. 1974

[31] Spitsyn and Ionova 1978a

[32] Spitsyn and Ionova $1978 b$ 
Figure 2-1. Oxidation Potentials Scheme of Actinides in $1 \mathrm{M} \mathrm{HClO}_{4}$ and $1 \mathrm{M} \mathrm{NaOH}$ Media (in Volts vs. Standard Hydrogen Electrode).

$1 \mathrm{M} \mathrm{HClO}_{4}$

$1 \mathrm{M} \mathrm{NaOH}$

$U(V I) \frac{0.06}{-0.65} U(V) \frac{0.58}{-1.1} U(I V) \stackrel{-0.63}{-} U($ III) $\stackrel{-1.80}{-} U(0)$

$1 \mathrm{M} \mathrm{HClO}_{4}$
$1 \mathrm{M} \mathrm{NaOH}$ $\mathrm{Np}(\mathrm{VII}) \frac{2.04}{0.59} \mathrm{~Np}(\mathrm{VI}) \frac{1.14}{0.14} \mathrm{~Np}(\mathrm{~V}) \frac{0.74}{-0.95} \mathrm{~Np}(\mathrm{IV}) \frac{0.15}{-1.8} \mathrm{~Np}(\mathrm{III}) \frac{-1.82}{\mathrm{~Np}(0)}$

$1 \mathrm{M} \mathrm{HClO}_{4}$
$1 \mathrm{M} \mathrm{NaOH}(\mathrm{VII})$$\frac{2.3}{0.85} \mathrm{Pu}(\mathrm{VI}) \frac{0.92}{0.12} \mathrm{Pu}(\mathrm{V}) \frac{1.17}{-0.67} \mathrm{Pu}(\mathrm{IV}) \frac{0.98}{-0.96} \mathrm{Pu}(\mathrm{III}) \frac{-2.02}{\mathrm{Pu}(0)}$

$1 \mathrm{M} \mathrm{HClO}_{4}$
$1 \mathrm{M} \mathrm{NaOH}$ $\mathrm{Am}(\mathrm{VII}) \frac{2.5}{1.05} \mathrm{Am}(\mathrm{VI}) \frac{1.6}{0.68} \mathrm{Am}(\mathrm{V}) \frac{0.82}{0.4} \mathrm{Am}(\mathrm{IV}) \frac{2.62}{0.27} \mathrm{Am}(\mathrm{III}) \frac{-2.3}{\mathrm{Am}(0)}$

$\begin{aligned} & 1 \mathrm{M} \mathrm{HClO}_{4} \\ & 1 \mathrm{M} \mathrm{NaOH}\end{aligned} \mathrm{Cm}(\mathrm{VII})-\mathrm{Cm}(\mathrm{VI}) \frac{1.5}{0.7} \mathrm{Cm}(\mathrm{V}) \frac{1.7}{2} \mathrm{Cm}(\mathrm{IV}) \frac{3.1}{1.2} \mathrm{Cm}$ (III) $\frac{-2.69}{\mathrm{Cm}(0)}$ 


\subsection{Pu(V)/Pu(IV) OXIDATION POTENTIAL AND STABILITY OF Pu(V) AND Pu(IV) IN ALKALINE MEDIA}

The $\mathrm{Pu}(\mathrm{V}) / \mathrm{Pu}(\mathrm{IV})$ oxidation potential in $1 \mathrm{M} \mathrm{NaOH}$, calculated by $\mathrm{Kraus}$ (1949) as $E^{\circ}=0.76 \mathrm{~V}$ vs. the standard hydrogen electrode (SHE) (Simakin 1977) is widely cited (Martinot and Fuger [1985]; and Katz et al. [1986a]). In his calculations, Kraus (1949) has taken into account that the $\mathrm{PuO}_{2}^{+} / \mathrm{Pu}^{4+}$ potential in acidic solutions decreases with an increase of $\mathrm{pH}$ at the rate $236 \mathrm{mV} / \mathrm{pH}$. He made the questionable assumption that the $\mathrm{Pu}(\mathrm{V}) / \mathrm{Pu}(\mathrm{IV})$ oxidation potential is $\mathrm{pH}$-independent in the range $1.4<\mathrm{pH}<10$. He based this assumption on the hydrolysis of the reduced form [Pu(IV)] and assumed that the oxidized form [Pu(V)] does not undergo hydrolytic reactions in these conditions. At $\mathrm{pH}$ values greater than 10, Kraus assumed the further decrease of the oxidation potential value with the rate of 59 $\mathrm{mV} / \mathrm{pH}$. Using this assumption and the value of $\mathrm{Pu}(\mathrm{IV})$ polymerization free energy, Kraus obtained his reported value of $\mathrm{Pu}(\mathrm{V}) / \mathrm{Pu}(\mathrm{IV})$ oxidation potential $\left(\mathrm{E}^{\circ}=0.76 \mathrm{~V}\right)$. Since 1949 , Kraus has published splendid and accurate data on plutonium chemistry, but he never reconsidered his data on the plutonium oxidation potentials in alkaline media. The redox potential value, reported by Kraus, compared with the value of $\mathrm{Pu}(\mathrm{VI}) / \mathrm{Pu}(\mathrm{V})$ potential $\left(\mathrm{E}^{\circ}=0.23 \mathrm{~V}\right.$ vs SHE in $\left.1 \mathrm{M} \mathrm{NaOH}\right)$ shows the possibility of $\mathrm{Pu}(\mathrm{V})$ disproportionation in alkaline solutions, as occurs in acidic media. The instability of $P u(V)$ and its ability to disproportionate in alkaline solutions is emphasized in many modern books dealing with plutonium chemistry (Martinot and Fuger 1985; and Katz et al. 1986a).

In studies of $\mathrm{Pu}(\mathrm{VI})$ electrochemical reduction to $\mathrm{Pu}(\mathrm{V})$ in 1 to $4 \mathrm{M} \mathrm{NaOH}$, Bourges (1972) proved $\mathrm{Pu}(\mathrm{V})$ hydroxide to be stable and soluble. Moreover, he found $\mathrm{Pu}(\mathrm{IV})$ hydroxide fresh precipitate dissolved in these solutions when $\mathrm{Pu}(\mathrm{VI})$ was added. Dissolved species of $\mathrm{Pu}(\mathrm{V})$ were proved to be the product of the latter reaction. These observations mean that the well known disproportionation reaction of $\mathrm{Pu}(\mathrm{V})$, occurring in acidic media, changes its direction in alkaline solutions.

$$
2 \mathrm{Pu}(\mathrm{V}) \underset{\mathrm{HNO}_{3}}{\stackrel{\mathrm{NaOH}}{\leftrightarrows}} \mathrm{Pu}(\mathrm{IV})+\mathrm{Pu}(\mathrm{VI})
$$

Unfortunately, Bourges (1972) did not measure the value of the $\mathrm{Pu}(\mathrm{V}) / \mathrm{Pu}(\mathrm{IV})$ oxidation potential, but estimated it as $\mathrm{E}^{\circ}=0.35 \mathrm{~V}$ vs. SHE for $1 \mathrm{M} \mathrm{NaOH}$. The latter result seems to contradict his own data on the $\mathrm{Pu}(\mathrm{VI})$ - $\mathrm{Pu}(\mathrm{IV})$ reproportionation with formation of $\mathrm{Pu}(\mathrm{V})$.

The $\mathrm{Pu}(\mathrm{V}) / \mathrm{Pu}(\mathrm{IV})$ oxidation potential in $1 \mathrm{M} \mathrm{NaOH}$ was determined for the first time using electrochemical measurements (Peretrukhin and Alekseeva, 1974a). In spite of the low solubility of $\mathrm{Pu}(\mathrm{IV})$ in alkaline media, direct current polarograms of the irreversible $\mathrm{Pu}(\mathrm{V})$ reduction to Pu(IV) were recorded using a dropping mercury electrode. The value of the $\mathrm{Pu}(\mathrm{V}) / \mathrm{Pu}(\mathrm{IV})$ oxidation potential in $1 \mathrm{M} \mathrm{NaOH}$ was determined as:

$$
E^{\circ}=E_{1 / 2}-E_{\text {dif. }}-E_{\text {over }}
$$


where: $\mathrm{E}_{12}$ is the half-wave potential of $\mathrm{Pu}(\mathrm{V}) / \mathrm{Pu}(\mathrm{IV})$ reduction, determined experimentally;

$E_{\text {dif. }}$ is the diffusion potential in the liquid junction of the reference electrode, reliably estimated in the literature as $30 \mathrm{mV}$; and $\mathrm{E}_{\text {over. }}$ is the overvoltage of $\mathrm{Pu}(\mathrm{V})$ reduction arising from the irreversibility of the electrochemical process. The $E_{\text {over. }}$ was estimated as $0.13 \mathrm{mV}$ using the results of the study of Am(IV) electrochemical oxidation in $1 \mathrm{M} \mathrm{NaOH}$. The application of such an approach for estimating the $\mathrm{Pu}(\mathrm{V}) / \mathrm{Pu}(\mathrm{IV})$ oxidation potential resulted in the value $-0.67 \mathrm{~V}$ vs. SHE.

The difference of the value obtained by Peretrukhin et al. (1993) from that of Kraus (1949) $(+0.76 \mathrm{~V}$ vs. SHE) (Figure 2-2) is large and indicates one of them is erroneous. All the data on the chemical behavior of $\mathrm{Pu}(\mathrm{V})$ in alkaline media [(for example, its high stability and formation as a result of reproportionation of $\mathrm{Pu}(\mathrm{VI})$ and $\mathrm{Pu}(\mathrm{IV})]$ appear to contradict the value $0.76 \mathrm{~V}$ vs. SHE and more likely confirm the value reported by Peretrukhin et al. (1993). Moreover, the value $\mathrm{E}^{\circ}=-0.67 \mathrm{~V}$ vs. SHE indicates that the oxidation of $\mathrm{Pu}(\mathrm{IV})$ to $\mathrm{Pu}(\mathrm{V})$ by several oxidizing agents, such as $\mathrm{O}_{2}, \mathrm{CrO}_{4}{ }^{2-}$, and $\mathrm{Fe}$ (III) as $\mathrm{FeO}_{2}^{-}$ions, should be possible in alkaline media.

Noticeable dissolution of $\mathrm{PuO}_{2} \cdot \mathrm{xH}_{2} \mathrm{O}$ in air-equilibrated 1 to $15 \mathrm{M} \mathrm{NaOH}$ solutions was reported by Delegard (1987). Later, the dissolution of $\mathrm{Pu}(\mathrm{IV})$ hydroxide in 2 to $8 \mathrm{M} \mathrm{NaOH}$ solutions, purged by air during a 1-month period, has been reported in a common RussianFrench study (Peretrukhin et al. 1994). They have found that plutonium concentration $\left(4.0 \times 10^{-5} \mathrm{M}\right)$ in air-equilibrated solutions after a 1-month exposure had appeared to be 100 times greater if compared with the same solutions purged with argon and used as a reference. The concentration of soluble plutonium(V) in 2 to $8 \mathrm{M} \mathrm{NaOH}$ in the presence of $\mathrm{Fe}(\mathrm{OH})_{3}, \mathrm{Cr}(\mathrm{OH})_{3}, \mathrm{~K}_{2} \mathrm{CrO}_{4}$, and $\mathrm{Co}(\mathrm{OH})_{3}$ also was found to increase during a 1-month exposure. This chemical observation once more proves that the value of oxidation potential for $\mathrm{Pu}(\mathrm{V}) / \mathrm{Pu}(\mathrm{IV})(-0.67 \mathrm{~V}$ vs. SHE) accords better with reality.

Diagrams of $\mathrm{E}^{\circ}-\mathrm{pH}$ for $\mathrm{Np}, \mathrm{Pu}$, and Am, taken from Maslennikov et al. (1993) and shown in Figure 2-3, may be successfully used for predicting the directions of actinide redox reactions. Note that the value of $\mathrm{Pu}(\mathrm{V}) / \mathrm{Pu}(\mathrm{IV})$ potential in neutral media, shown in Figure 2-2, is lower than that reported in widely used books (Martinot and Fuger 1985; and Katz et al. 1986). The data in Figure 2-2 also indicate that $\mathrm{Pu}(\mathrm{V})$ should be stable toward disproportionation above $\mathrm{pH} 5$. This fact is consistent with the observation of $\mathrm{Pu}(\mathrm{V})$ reported for some natural waters (Bondietti and Trabalka 1980; and Nitsche 1991).

\subsection{OXIDATION POTENTIALS AND STABHLITY OF Np, Pu AND Am IN HIGHER OXIDATION STATES}

The values of oxidation potentials for the $\mathrm{Np}$ (VII)/Np(VI), $\mathrm{Np}(\mathrm{VI}) / \mathrm{Np}(\mathrm{V})$ (Zielen and Cohen 1970; Shilov et al. 1970; Simakin et al. 1973; Peretrukhin and Alekseeva 1974a; Ermakov et al. 1977b; and Peretrukhin et al. 1972) and $\mathrm{Pu}(\mathrm{VII}) / \mathrm{Pu}$ (VI) (Peretrukhin and Alekseeva 1974b) pairs have been determined potentiometrically. Voltammetric 
Figure 2-2. Pu Oxidation Potentials in $1 \mathrm{M} \mathrm{HClO}_{4}$ and in $1 \mathrm{M} \mathrm{NaOH}$.

Data Taken from Table 2-1.

References:

[1] Martinot and Fuger 1985

[2] Kraus 1949

[3] Bourges 1972

[4] Peretrukhin et al. 1993

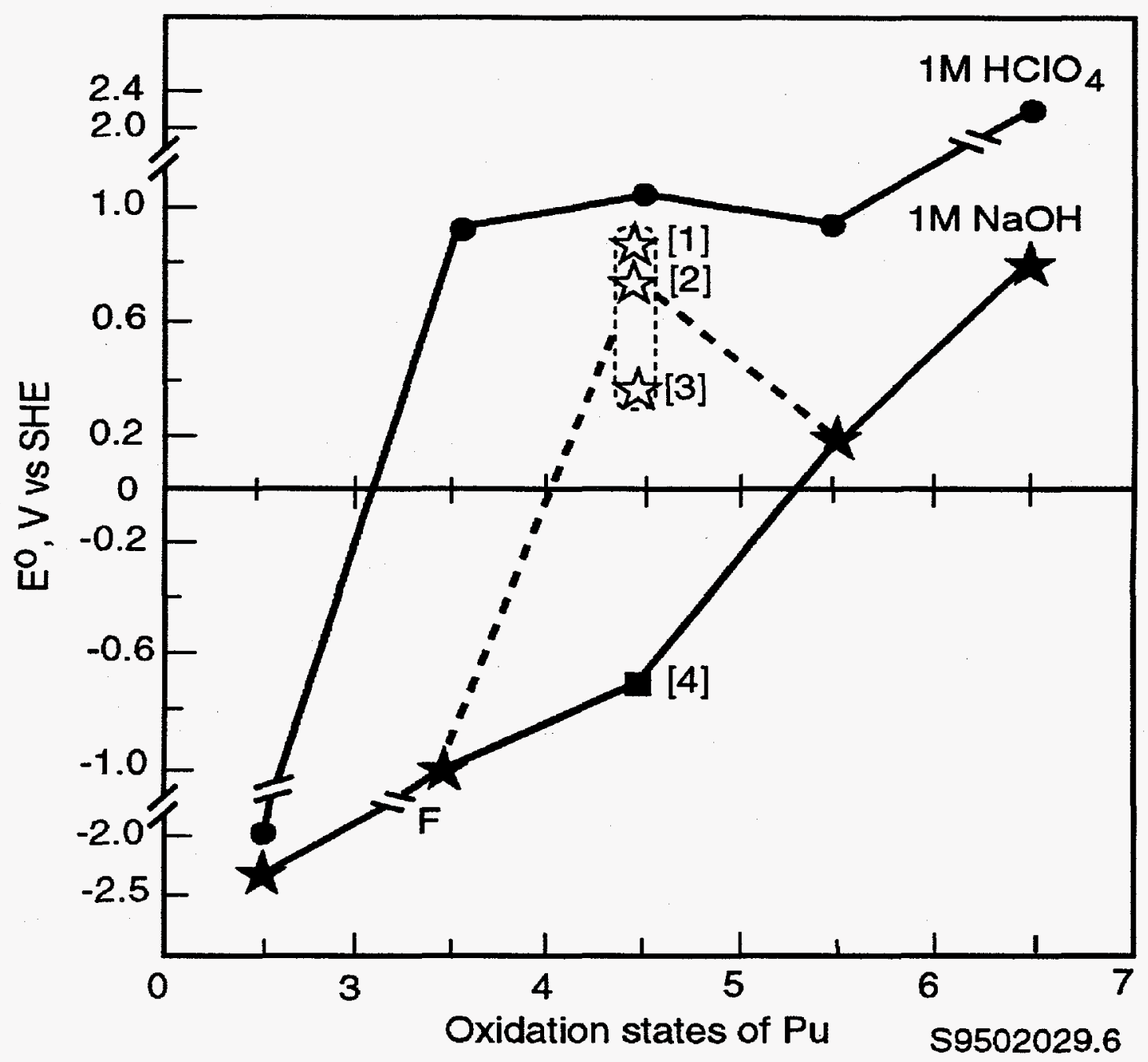


Figure 2-3. Redox Potentials of Actinides in Acidic and Alkaline Solutions. The Dashed Line is the E-pH Curve for Pu(V)-Pu(IV) Oxidation Potentials.

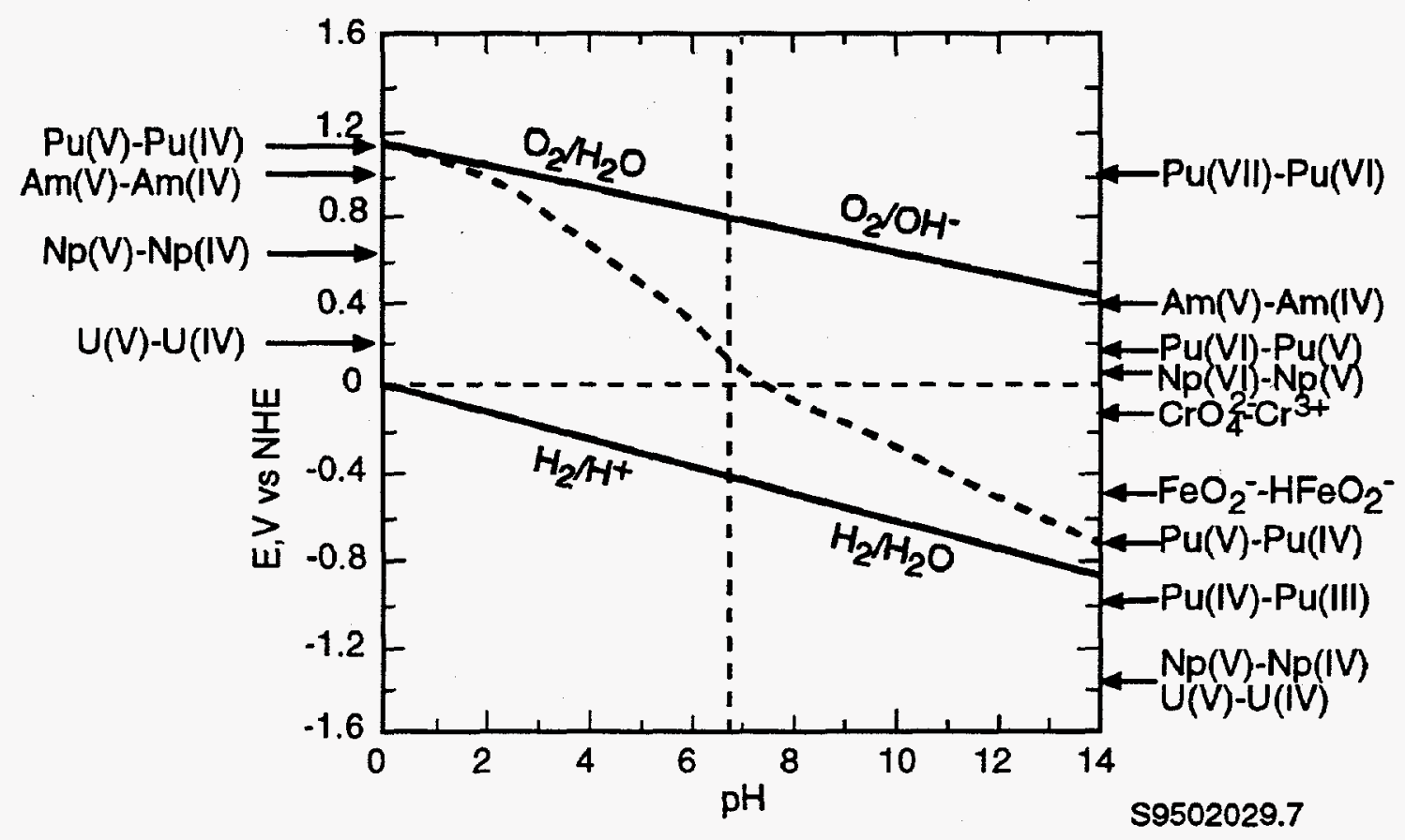


measurements have been carried out to determine potentials for $\mathrm{Pu}(\mathrm{VII}) / \mathrm{Pu}(\mathrm{VI})$, $\mathrm{Pu}(\mathrm{VI}) / \mathrm{Pu}(\mathrm{V}), \mathrm{Pu}(\mathrm{V}) / \mathrm{Pu}(\mathrm{IV})$ and $\mathrm{Pu}(\mathrm{IV}) / \mathrm{Pu}(\mathrm{III})$ redox pairs (Peretrukhin and Alekseeva 1974b). The data on $\mathrm{Np}$ and $\mathrm{Pu}$ oxidation potentials in higher oxidation states are presented in Figure 2-4. Only small differences have been noticed between the potential values determined in $\mathrm{NaOH}$ and $\mathrm{LiOH}$ at the same $\mathrm{OH}^{-}$concentrations (Ermakov et al. 1977a). Alkaline concentrations, expressed in the original studies in molarity, $M$, have been changed to the corresponding values of activities $\mathrm{a}=\mathrm{m} \gamma$, where $\mathrm{m}$, molality, is the alkaline concentration in mol per 1000 grams $\mathrm{H}_{2} \mathrm{O}$ and $\gamma$ is the activity coefficient. The calculations were made using handbook data for the densities of $\mathrm{NaOH}$ solutions and corresponding data on the $\gamma$ of $\mathrm{NaOH}$ and $\mathrm{LiOH}$ (Handbook 1964).

The dependence of neptunium $\mathrm{E}_{\mathrm{f}}^{\mathrm{vI} / \mathrm{VI}}$ oxidation potentials on the logarithm of the $\mathrm{NaOH}$ activity in solution plots as a convex curve. In the range $0.07<\mathrm{a}<0.2$, the tangent, drawn with three experimental points, has a slope of $-1.5 \times 0.059 \mathrm{~V}$ per unit $\log \left(\mathrm{a}_{\mathrm{NnOH}}\right)$. When the $\mathrm{NaOH}$ activity exceeds 0.2 , the absolute value of the slope becomes greater. Oxidation potential values, determined in $0.33 \mathrm{M} \mathrm{LiOH}$, also are located on this curve. Therefore the nature of alkali does not affect the potential value if the activity is used instead of the concentration.

Measurements, carried out at constant ionic strength $(\mu=1)$ in $\mathrm{NaOH} / \mathrm{NaClO}_{4}$ solutions (Zielen and Cohen 1970) and in $\mathrm{NaOH} / \mathrm{NaNO}_{3}$ solutions $(\mu=1.0$ and $\mu=1.5$ ) (Shilov 1970), have shown that Np(VI) oxidation to $N p(V I I)$ takes place with the participation of two $\mathrm{OH}^{-}$ions. Other studies show that $\mathrm{Np}$ (VII) in alkaline media forms mainly $\mathrm{NpO}_{4}(\mathrm{OH})_{2}^{3-}$ species (Krot et al. 1977). The rapid reversibility of the $\mathrm{Np}(\mathrm{VII}) / \mathrm{Np}(\mathrm{VI})$ pair indicates that the ion structures are similar and coordination numbers in both oxidation states are equal to 6 . Therefore $\mathrm{Np}$ (VI) in alkaline solutions most probably exists as $\mathrm{NpO}_{4}\left(\mathrm{H}_{2} \mathrm{O}\right)_{2}^{2-}$ or $\mathrm{NpO}_{2}(\mathrm{OH})_{4}^{2-}$. The redox $\mathrm{Np}(\mathrm{VI}) \rightleftarrows \mathrm{Np}(\mathrm{VII})$ equilibrium may be written as:

$$
\mathrm{NpO}_{2}(\mathrm{OH})_{4}^{2-}\left[\text { or } \mathrm{NpO}_{4}\left(\mathrm{H}_{2} \mathrm{O}\right)_{2}^{2-}\right]+2 \mathrm{OH}^{-} \rightleftarrows \mathrm{NpO}_{4}(\mathrm{OH})_{2}^{3-}+2 \mathrm{H}_{2} \mathrm{O}+\mathrm{e}^{-}
$$

The Nernst equation for this electrochemical process will look like

$$
E_{f}^{V I I / V I}=E^{0, V I / V I}+\frac{R T}{n F} \ln \frac{[N p(V I I)] \gamma_{3-} a_{H_{2} \mathrm{O}}^{2}}{[N p(V I)] \gamma_{2}-a_{\mathrm{OH}^{-}}^{2}}
$$

In concentrated $\mathrm{NaOH}$ solutions, the slope $\mathrm{E}_{\mathrm{f}} \mathrm{vs}$. $\log \left(\mathrm{a}_{\mathrm{NaOH}}\right)$ increases to $-3.36 \times 0.059$. The additional potential drop is accounted for by the decrease of the $\gamma_{3} / \gamma_{2}$. ratio and by the decrease of water activity. The slope of this curve in dilute alkaline solutions, equal to $-1.5 \times 0.059$, proves that the electrochemical process may occur by two parallel pathways (1) and (3):

$$
\mathrm{NpO}_{4}\left(\mathrm{H}_{2} \mathrm{O}\right)_{2}^{2-}+\mathrm{OH}^{-} \rightleftarrows \mathrm{NpO}_{4}(\mathrm{OH})\left(\mathrm{H}_{2} \mathrm{O}\right)^{2-}+\mathrm{H}_{2} \mathrm{O}+\mathrm{e}^{-}
$$


Figure 2-4. Dependence of Actinide Formal Potentials on Alkali Concentration.
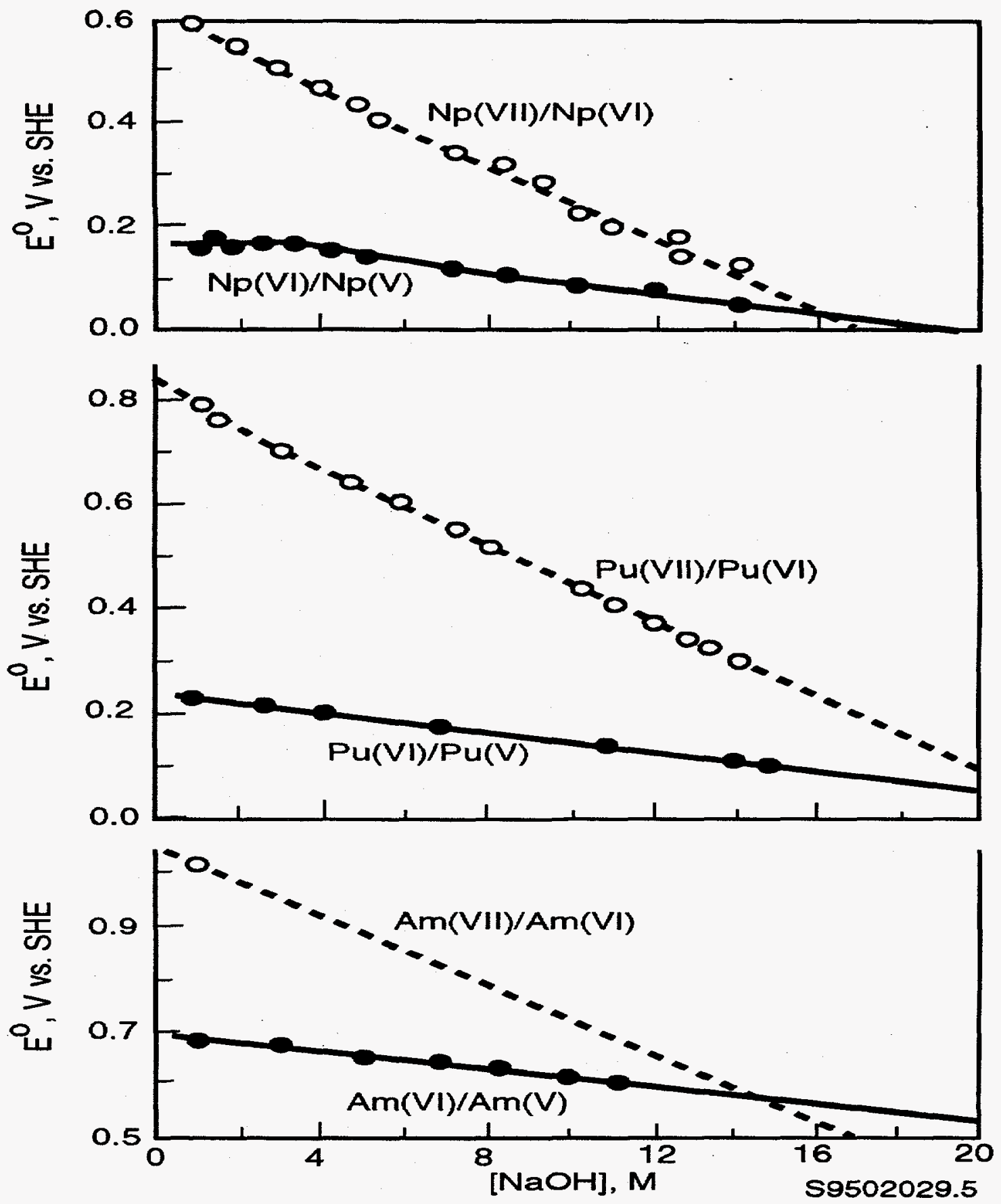
The dependence of $\mathrm{E}^{\text {o.VIV }}$ on $\log \left(\mathrm{a}_{\mathrm{NaOH}}\right)$ looks like a concave curve; the slope at low $\mathrm{NaOH}$ concentration is $-3 \times 0.059$. When the $\mathrm{a}_{\mathrm{NaOH}}$ becomes greater than 0.8 , the absolute value of the slope decreases to $-0.93 \times 0.059$.

Compounds of $\mathrm{Np}(\mathrm{V})$ with alkali metals $(\mathrm{Me})$ were precipitated from alkaline solutions of different concentrations. The ratios $\mathrm{Me} / \mathrm{Np}$ in these compounds are presented in Table 2-2.

Table 2-2. Me/Np Ratios in Solid Np(V) Compounds, Precipitated From Alkaline Solutions of Different Concentrations.

\begin{tabular}{|c|c|c|c|}
\hline $\mathrm{NaOH}$ conc., $\mathrm{M}$ & 0.02 & 2.1 & 15.0 \\
\hline $\mathrm{Me} / \mathrm{Np}$ in precipitate & $\cong 0.01$ & $1.01 \pm 0.03$ & $2.2 \pm 0.03$ \\
\hline
\end{tabular}

Thus in $\mathrm{NaOH}$ solutions, $\mathrm{Np}(\mathrm{V})$ may exist as $\mathrm{NpO}_{2} \mathrm{OH} \cdot \mathrm{xH}_{2} \mathrm{O}, \mathrm{NpO}_{2}(\mathrm{OH})_{2}\left(\mathrm{H}_{2} \mathrm{O}\right)_{2}$, $\mathrm{NpO}_{2}(\mathrm{OH})_{3}\left(\mathrm{H}_{2} \mathrm{O}\right)^{2-}$ and $\mathrm{NpO}_{2}(\mathrm{OH})_{4}{ }^{3-}$. Coordination number 6 was found to be characteristic for $N p(V)$ in alkaline solutions since the $N p(V) / N p(V I)$ redox pair is reversible and redox transformations are rapid. The existence of practically all mentioned ionic states of neptunium(V) was proved spectrophotometrically (Tananaev 1990b). Electrochemical $\mathrm{Np}(\mathrm{V}) / \mathrm{Np}(\mathrm{VI})$ processes in dilute alkaline solutions take place according to the reactions:

$$
\begin{gathered}
\mathrm{NpO}_{2} \mathrm{OH} \cdot \mathrm{xH}_{2} \mathrm{O}+3 \mathrm{OH}^{-} \rightleftarrows \mathrm{NpO}_{2}(\mathrm{OH})_{4}^{2-}+\mathrm{x}_{2} \mathrm{O}+\mathrm{e}^{-} \\
\mathrm{NpO}_{2}(\mathrm{OH})_{2}\left(\mathrm{H}_{2} \mathrm{O}\right)_{2}^{-}+2 \mathrm{OH}^{-} \rightleftarrows \mathrm{NpO}_{2}(\mathrm{OH})_{4}^{2-}+2 \mathrm{H}_{2} \mathrm{O}+\mathrm{e}^{-}
\end{gathered}
$$

In solutions with $\mathrm{a}_{\mathrm{NaOH}}$ greater than 0.8 , the reaction is:

$$
\mathrm{NpO}_{2}(\mathrm{OH})_{3}\left(\mathrm{H}_{2} \mathrm{O}\right)^{2-}+\mathrm{OH}^{-} \rightleftarrows \mathrm{NpO}_{2}(\mathrm{OH})_{4}^{2-}+\mathrm{H}_{2} \mathrm{O}+\mathrm{e}^{-}
$$

The dependence of $E_{f}^{\mathrm{VI} / \mathrm{V}}$ on the solution composition should look like:

$$
E_{f}^{\mathrm{v} / \mathrm{V}}=E^{o, \mathrm{~V} J \mathrm{~V}}+\frac{\mathrm{RT}}{\mathrm{nF}} \ln \frac{[\mathrm{Np}(\mathrm{VI})] \gamma_{2-} \mathrm{a}_{\mathrm{H}_{2} \mathrm{O}}}{[\mathrm{Np}(\mathrm{V})] \gamma_{2-} \mathrm{a}_{\mathrm{OH}}^{-}}
$$

Because the slope of this curve, determined experimentally, was found to be $-0.93 \times 0.059$ instead of $-1.0 \times 0.059$, the reaction:

$$
\mathrm{NpO}_{2}(\mathrm{OH})_{4}^{3-} \rightleftarrows \mathrm{NpO}_{2}(\mathrm{OH})_{4}^{2-}+\mathrm{e}^{-}
$$


seems to play a certain role in the electrochemical process. In the latter case, the value of the $\gamma_{2} / \gamma_{3}$. ratio should be included in the equation for $E_{f}^{v V / v}$ determination. This ratio increases approximately $0.06 \mathrm{~V}$ per unit of $\log \left(\mathrm{a}_{\mathrm{NaOH}}\right)$, opposite the trend noticed for the $\mathrm{Np}(\mathrm{VII}) / \mathrm{Np}(\mathrm{VI})$ redox equilibrium. This increase to some extent depresses the potential drop caused by reaction 8 .

The dependence of $\mathrm{E}_{\mathrm{f}}^{\mathrm{VI} / \mathrm{VI}}$ on $\log \left(\mathrm{a}_{\mathrm{NaOH}}\right)$ for plutonium is expressed by a convex curve. The tangent of the starting part of the curve has a slope $-2 \times 0.059$, indicating the participation of two hydroxide ions in the redox reaction. $\mathrm{Pu}(\mathrm{VII})$ exists in alkaline solutions as $\mathrm{PuO}_{4}(\mathrm{OH})_{2}^{3-}$ (Krot et al. 1977). Because of the demonstrated reversibility of the Pu(VII)/Pu(VI) pair and the high rate of the corresponding redox reactions, $\mathrm{Pu}$ ions in both oxidation states are likely to possess similar structures and the same coordination number 6 . Therefore the most probable forms for plutonium(VI) existence in alkaline media are $\mathrm{PuO}_{2}(\mathrm{OH})_{4}^{2-}$ and $\mathrm{PuO}_{4}\left(\mathrm{H}_{2} \mathrm{O}\right)_{2}^{2-}$. The equation of the redox reaction in alkaline media has the form:

$$
\mathrm{PuO}_{4}\left(\mathrm{H}_{2} \mathrm{O}\right)_{2}^{2-}\left[\text { or } \mathrm{PuO}_{2}(\mathrm{OH})_{4}^{2-}\right]+2 \mathrm{OH}^{-} \rightleftarrows \mathrm{PuO}_{4}(\mathrm{OH})_{2}^{3-}+2 \mathrm{H}_{2} \mathrm{O}+\mathrm{e}^{-}
$$

and the Nernst equation may be written as

$$
E_{f}^{\text {VIIVI }}=E^{o, v I / v I}+\frac{R T}{n F} \ln \frac{[P u(V I I)] \gamma_{3}-a_{\mathrm{H}_{2} \mathrm{O}}^{2}}{[\mathrm{Pu}(\mathrm{VI})] \gamma_{2}-\mathrm{a}_{\mathrm{OH}^{-}}^{2}}
$$

In concentrated $\mathrm{NaOH}$ solutions the downward slope of the curve $\mathrm{E}_{\mathrm{f}}^{\mathrm{vI} / \mathrm{VI}}$ vs. $\log \left(\mathrm{a}_{\mathrm{NaOH}}\right)$ is found to increase, reaching $-3.09 \times 0.059$. The additional potential drop of $0.060 \mathrm{~V}$ per unit $\log \left(\mathrm{a}_{\mathrm{NaOH}}\right)$ is caused by the reduction of the $\gamma_{2} / \gamma_{3}$, ratio and the simultaneous reduction of water activity.

The $E_{f}{ }^{v I / V}$ potential for the $\mathrm{Pu}(\mathrm{VI}) / \mathrm{Pu}(\mathrm{V})$ pair was found to decrease by $20 \mathrm{mV} / \mathrm{unit}$ $\log \left(\mathrm{a}_{\mathrm{NaOH}}\right)$. $\mathrm{Pu}(\mathrm{V})$ compounds, obtained by $\mathrm{Pu}(\mathrm{VI})$ reduction, were isolated from $4 \mathrm{M} \mathrm{NaOH}$ solution. They were found to be of the same structure as the corresponding $\mathrm{Np}(\mathrm{V})$ compounds: $\mathrm{MeNpO}_{2} \cdot \mathrm{xH}_{2} \mathrm{O}$ and $\mathrm{Me}_{2} \mathrm{NpO}_{2}(\mathrm{OH})_{3} \cdot \mathrm{xH}_{2} \mathrm{O}$ (Tananaev 1992). Based on these data it may be assumed that $\mathrm{Pu}(\mathrm{V})$ exists in alkaline solutions as $\mathrm{PuO}_{2}(\mathrm{OH})_{2}\left(\mathrm{H}_{2} \mathrm{O}\right)_{2}$ and $\mathrm{PuO}_{2}(\mathrm{OH})_{3}\left(\mathrm{H}_{2} \mathrm{O}\right)^{2-}$ ions, containing a number of water molecules satisfying the coordination number 6. If $\mathrm{Pu}(\mathrm{V})$ participates in redox reactions as an anion with a double negative charge, the redox equilibrium may be written as:

$$
\mathrm{PuO}_{2}(\mathrm{OH})_{3}\left(\mathrm{H}_{2} \mathrm{O}\right)^{2-}+\mathrm{OH}^{-} \rightleftarrows \mathrm{PuO}_{2}(\mathrm{OH})_{4}^{2-}+\mathrm{H}_{2} \mathrm{O}+\mathrm{e}^{-}
$$


and the dependence of $E_{f}^{V V V}$ on the solution composition should have the form:

$$
E_{f}^{v y / v}=E^{0, v y v}+\frac{R T}{n F} \ln \frac{[P u(V I)] \gamma_{2-} a_{H_{2} \mathrm{O}}}{[\mathrm{Pu}(V)] \gamma_{2}-a_{\mathrm{OH}^{-}}}
$$

It is difficult to imagine a significant difference between the activity coefficients of Pu(VI) and $\mathrm{Pu}(\mathrm{V})$. Therefore the mechanism of the electrochemical process including the two parallel reactions (11) and (13) may be assumed.

$$
\mathrm{PuO}_{2}(\mathrm{OH})_{4}^{3-} \rightleftarrows \mathrm{PuO}_{2}(\mathrm{OH})_{4}^{2-}+\mathrm{e}^{-}
$$

In the latter case, the $\gamma_{2} / \gamma_{3}$ ratio should be included in the Nernst equation. The latter ratio is known to increase $60 \mathrm{mV}$ per unit $\log \left(\mathrm{a}_{\mathrm{N}_{2} \mathrm{OH}}\right)$, opposite to the trend noticed in the $\mathrm{Pu}(\mathrm{VII}) / \mathrm{Pu}$ (VI) pair. This increase impedes to a significant degree the potential drop caused by reaction (11).

The dependence of $\mathrm{E}_{\mathrm{f}}^{\mathrm{V} / \mathrm{IV}}$ on $\log \left(\mathrm{a}_{\mathrm{NaOH}}\right)$ may be satisfactorily explained by a semilogarithmic plot. The slope of the plot is $-2 \times 0.059$ per unit $\log \left(\mathrm{a}_{\mathrm{N} 2 \mathrm{OH}}\right)$. Therefore the equation of the redox reaction $\mathrm{Pu}(\mathrm{IV}) / \mathrm{Pu}(\mathrm{V})$, taking into account the chemical state of the latter in the alkaline solution, is consistent with:

$$
\mathrm{Pu}(\mathrm{OH})_{5}^{-}+2 \mathrm{OH}^{-} \rightleftarrows \mathrm{PuO}_{2}(\mathrm{OH})_{3}\left(\mathrm{H}_{2} \mathrm{O}\right)^{2-}+\mathrm{H}_{2} \mathrm{O}+\mathrm{e}^{-}
$$

The Nernst equation for this equation may be written as:

$$
\mathrm{E}_{\mathrm{f}}^{\mathrm{V} / \mathrm{V}}=\mathrm{E}^{\mathrm{o}, \mathrm{V} / \mathrm{IV}}+\frac{\mathrm{RT}}{\mathrm{nF}} \ln \frac{[\mathrm{Pu}(\mathrm{V})] \gamma_{2-} \mathrm{a}_{\mathrm{H}_{2} \mathrm{O}}}{[\mathrm{Pu}(\mathrm{IV})] \gamma_{-} \mathrm{a}_{\mathrm{OH}^{-}}^{2}}
$$

The possibility of the existence of the $\mathrm{Pu}(\mathrm{OH})_{5}^{-}$form in alkaline media is made after careful comparison of corresponding U(IV) hydroxide behavior. U(IV) is known to undergo hydrolysis according to the complex five-step mechanism.

$$
\mathrm{U}^{4+}+5 \mathrm{H}_{2} \mathrm{O} \rightleftarrows \mathrm{U}(\mathrm{OH})_{5}^{-}+5 \mathrm{H}^{+} ; \log \mathrm{K}_{\mathrm{h}}=-13.0 \text { (Katz et al. 1986a) }
$$

Moreover, the compound $\mathrm{NH}_{4} \mathrm{U}(\mathrm{OH})_{5}$ was prepared under hydrothermal conditions and its structure has been investigated (Mefod'eva and Krot 1987). 
The oxidation potential of the $\mathrm{Pu}(\mathrm{IV}) / \mathrm{Pu}(\mathrm{III})$ pair is linearly dependent on $\log \left(\mathrm{a}_{\mathrm{NaOH}}\right)$; the slope is $-0.15 \mathrm{~V}$ per unit $\log \left(\mathrm{a}_{\mathrm{NaOH}}\right)$. Redox equilibrium in the $\mathrm{Pu}(\mathrm{IV}) / \mathrm{Pu}(\mathrm{III})$ system may be described by the equation:

$$
\mathrm{Pu}(\mathrm{OH})_{3} \cdot \mathrm{xH}_{2} \mathrm{O}+2 \mathrm{OH}^{-} \rightleftarrows \mathrm{Pu}(\mathrm{OH})_{5}^{-}+\mathrm{x} \mathrm{H}_{2} \mathrm{O}+\mathrm{e}^{-}
$$

Such a reaction should give the slope equal to $2 \times 0.059$. The reason for the additional potential drop has not yet been found.

The form of existence of actinide ions in alkaline media deduced from considerations of redox equilibria do not exclude the possibility of the existence of other chemical states proved by different analytical techniques. This is particularly the case for $\mathrm{Pu}(\mathrm{IV})$ species, known to be present in alkaline solutions mainly as $\mathrm{PuO}_{2} \cdot \mathrm{xH}_{2} \mathrm{O}$. Oxidation potentials of the actinides in neutral and alkaline solutions were calculated using the information about the different chemical forms of the actinides (Connick 1955; and Latimer 1954). To estimate the oxidation potential for the $\mathrm{Am}(\mathrm{VI}) / \mathrm{Am}(\mathrm{V})$ pair, the hydrolysis constants of $\mathrm{PuO}_{2}^{2+}$ and $\mathrm{PuO}_{2}^{+}$ in solutions with $\mathrm{pH}$ greater than 7 were used. In the case of $\mathrm{Np}$ and $\mathrm{Pu}$, the theoretical estimates were found to be in good compliance with experimental data (Simakin et al. 1973; Bourges 1972; and Peretrukhin and Alekseeva 1974b). At the same time, the experimentally determined oxidation potential values for Am appear to be approximately $400 \mathrm{mV}$ lower than predicted by theoretical estimations (Nikolayevsky et al. 1974).

In the case of the $\mathrm{Pu}(\mathrm{V}) / \mathrm{Pu}(\mathrm{IV})$ pair, the calculations of oxidation potential have given $0.86 \mathrm{~V}$, while experimental data have shown $-0.75 \mathrm{~V}$ (Peretrukhin and Alekseeva 1974b). As previously discussed, such a significant discrepancy is caused by several effects. In particular, to calculate the concentration of plutonium(IV) in alkaline solutions, the value deduced from the $\mathrm{Pu}(\mathrm{OH})_{4}$ solubility product, determined in weakly acidic solution, has been used. Because the composition of Pu(IV) hydroxide in equilibrium with alkaline solutions should differ sharply from that in weakly acidic media, this value should be used very carefully.

Among another oxidation potential values obtained by theoretical estimations, the potential of $\mathrm{Cm}(\mathrm{IV}) / \mathrm{Cm}$ (III) in $1 \mathrm{M} \mathrm{NaOH}$ seems to be doubtful. If $0.7 \mathrm{~V}$ were the potential for the $\mathrm{Cm}$ (IV)/Cm(III) couple, $\mathrm{Cm}$ (III) should be oxidized by ozone and other strong oxidizers. No experimental proof for this effect has been found (Mefod'eva and Krot 1987). The value reported for the $\mathrm{U}(\mathrm{VI}) / \mathrm{U}(\mathrm{IV})$ oxidation potential in $1 \mathrm{M} \mathrm{NaOH}$ also requires re-examination.

The thermodynamic stability of any actinide ion or compound is determined by several factors:

1. Propensity to disproportionation reactions; i.e., ability to form ions (compounds) containing actinides in oxidation states higher and lower than the starting material. $\mathrm{U}(\mathrm{V}), \mathrm{Np}(\mathrm{V}), \mathrm{Pu}(\mathrm{IV}), \mathrm{Pu}(\mathrm{V}), \mathrm{Am}(\mathrm{IV})$, and $\mathrm{Am}(\mathrm{V})$ are found to be unstable towards disproportionation in acidic media. In alkaline solutions, the mentioned ions lose this 
ability. At the same time, disproportionation reactions in alkaline media were reported for Np(VI) (Krot et al. 1970) and Am(VI) (Nikolayevsky et al. 1975b), and proved experimentally. Theoretically, in highly concentrated alkaline solutions, the disproportionation of $\mathrm{Pu}(\mathrm{VI})$ may be assumed, but until now, no experimental proof exists for this assumption.

2. Reactions between the ions of the same element present in the solution simultaneously in different oxidation states. For example in acidic media, U(III) reacts with $U(V)$ and $\mathrm{U}(\mathrm{VI}) ; \mathrm{Np}(\mathrm{III})$ reacts with $\mathrm{Np}(\mathrm{V}), \mathrm{Np}(\mathrm{VI})$, and $\mathrm{Np}(\mathrm{VII}) ; \mathrm{Np}(\mathrm{V})$ reacts with $\mathrm{Np}(\mathrm{VII})$; and $\mathrm{Pu}(\mathrm{III})$ reacts with $\mathrm{Pu}(\mathrm{V}), \mathrm{Pu}(\mathrm{VI})$, and $\mathrm{Pu}(\mathrm{VII})$. In alkaline media, hydroxides of $\mathrm{U}, \mathrm{Np}$, and $\mathrm{Pu}$ in oxidation states $(+3)$ and $(+4)$ exhibit the ability to reduce the corresponding actinide ions in oxidation states $(+6)$ and $(+7)$. At the same time actinide ions in oxidation state $(+7)$ are able to oxidize corresponding hydroxides in oxidation state $(+5)$.

3. Stability toward reactions with water to evolve with hydrogen or oxygen. In acidic media, only U(III), in being oxidized to U(IV), can reduce water to form molecular hydrogen. In alkaline solutions, U(III), Np(III), Np(IV), and Pu(III) hydroxide exhibit this possibility. $\mathrm{Np}(\mathrm{VII})$ and $\mathrm{Pu}(\mathrm{VII})$ in alkaline solutions oxidize water to form molecular oxygen. They are reduced to $\mathrm{Np}(\mathrm{VI})$ and $\mathrm{Pu}(\mathrm{VI})$, correspondingly.

\subsection{OXIDATION POTENTIALS AND STABILITY OF TECHNETIUM IONS IN ALKALINE MEDIA}

Oxidation potentials for the redox couples of technetium ions are presented in Table 2-3. Precise values are not determined for most of the oxidation potentials because of technetium instability in all oxidation states except $(+7)$. The potential values in acidic media are calculated indirectly using other thermodynamic functions of technetium. The values for $T c$ oxidation potentials in alkaline media, presented in Table 2-3, are the half-wave potentials of technetium obtained by polarographic reduction in alkaline media. Included in the potential values are the unknown values of the overvoltage of the electrochemical reductions (Founta et al. 1987). Nevertheless, the data presented in Table 2-3 are sufficiently reliable to predict instability of lower oxidation states of technetium in alkaline media.

The oxidation potential for the $\mathrm{Tc}(\mathrm{VII}) / \mathrm{Tc}(\mathrm{VI})$ couple $\left(\mathrm{E}^{\circ}=-0.64 \mathrm{~V}\right.$ vs. SHE) seems to be the most reliably determined couple in alkaline solution because the polarographic reduction of $\mathrm{Tc}(\mathrm{VII})$ to $\mathrm{Tc}(\mathrm{VI})$ was found to be reversible in $1 \mathrm{M} \mathrm{NaOH}$. In this case, the value of $E_{1 / 2}$ is known to be close to the value of the corresponding standard oxidation potential. The $\mathrm{Tc}(\mathrm{VI}) / \mathrm{Tc}(\mathrm{V})$ oxidation potential is more positive than that of $\mathrm{Tc}(\mathrm{VII}) / \mathrm{Tc}(\mathrm{VI})$. This means that $\mathrm{Tc}(\mathrm{VI})$ hydroxide compounds should possess low thermodynamic stability due to disproportionation.

$$
2 \mathrm{Tc}(\mathrm{VI}) \rightleftharpoons \mathrm{Tc}(\mathrm{VII})+\mathrm{Tc}(\mathrm{V})
$$


Table 2-3. Formal Oxidation Potential for Technetium Redox Couples in Acidic (Spitsyn and Kuzina 1981) and Alkaline

(Founta et al. 1987; and Deutsch et al. 1978) Media.

\begin{tabular}{|c|c|c|c|c|c|c|}
\hline Medium & VII/VI & VI/V & VI/IV & V/IV & IV/0 & $-1 / 0$ \\
\hline $1 \mathrm{M} \mathrm{HClO}_{4}$ & 0.57 & & 1.39 & 0.71 & 0.28 & -0.5 \\
\hline $1 \mathrm{M} \mathrm{NaOH}^{2}$ & -0.64 & -0.1 & & -0.88 & -1.35 & \\
\hline
\end{tabular}

This disproportionation reaction has been shown to be extremely fast at $\mathrm{pH}$ greater than 13 (Founta et al. 1987). Therefore it is impossible to prepare Tc(VI) solutions in alkaline media. $\mathrm{Tc}(\mathrm{V})$ and $\mathrm{Tc}(\mathrm{IV})$ should be more stable than $\mathrm{Tc}(\mathrm{VI})$ in alkaline solutions, but Tc(IV) hydroxide may be easily oxidized by many oxidizing agents usually present in alkaline radwastes $\left(\mathrm{O}_{2}, \mathrm{CrO}_{4}^{2-}\right.$, and others) possessing oxidation potentials, $\mathrm{E}^{\circ}$, greater than $-0.7 \mathrm{~V}$ in $1 \mathrm{M} \mathrm{NaOH}$.

\subsection{SOLUBILITY OF TRU HYDROXIDES AND SPECIATION IN ALKALINE MEDIA}

Amorphous friable hydroxides of actinides in the oxidation states $(+3)$ and $(+4)$ form when the corresponding acidic actinide solutions are neutralized to higher $\mathrm{pH}$ values. The precipitation follows actinide ions hydrolysis with formation of intermediate oxo-forms. The cations $\mathrm{AnOH}^{\mathrm{n}}$ or $\mathrm{AnO}_{2} \mathrm{OH}^{\mathrm{n}}$ are reported to be the primary products of the actinide hydrolysis in acidic solutions. Continued hydrolysis processes include the attachment of additional $\mathrm{OH}^{-}$groups to these cations. Irreversible hydroxoform polymerization occurs simultaneously with the primary hydrolysis until solid hydroxides form. The affinity for hydrolysis reactions for the actinide ions in different oxidation states decreases in the series:

$$
\mathrm{An}^{4+}>\mathrm{AnO}_{2}^{2+}>\mathrm{An}^{3+}>\mathrm{AnO}_{2}^{+}
$$

Actinide hydroxides in higher oxidation states possess marked amphoteric properties. The trend to formation of anionic species is found to increase in the row (Mefod'eva and Krot 1987):

$$
\mathrm{An}(\mathrm{IV})<\mathrm{An}(\mathrm{V})<\mathrm{An}(\mathrm{VI})<\mathrm{An}(\mathrm{VII})
$$

The precipitation of actinide(III) hydroxides is known to be complete in solutions with $\mathrm{pH}$ greater than 10. Lower actinide(III) hydroxides are unstable toward oxidation at higher $\mathrm{pH}$. Increase of the $\mathrm{pH}$ of $\mathrm{U}(\mathrm{III})$ and $\mathrm{Np}$ (III) solutions results in their oxidation to oxidation state $(+4)$ even in the absence of oxygen (see Section 2.2). The precipitate of Pu(III) hydroxide was shown to be comparatively quickly oxidized by atmospheric oxygen with 
formation of $\mathrm{Pu}(\mathrm{IV})$. $\mathrm{Am}(\mathrm{III})$ and $\mathrm{Cm}$ (III) hydroxide at first are precipitated in amorphous forms. After heating, their crystallization followed by dehydration was noticed. X-ray analyses of Am(III) and Cm(III) hydroxide crystals have shown that they possess a hexagonal cell with space symmetry group $\mathrm{P}_{3} / \mathrm{m}$ (Mefod'eva and Krot 1987). The nuclear gamma resonance spectrum of $\mathrm{Am}(\mathrm{OH})_{3}$ was found to have a chemical shift, d, of $4.6 \mathrm{~cm} / \mathrm{s}$ (vs. $\left.\mathrm{AmO}_{2}\right)\left(\mathrm{Mefod}\right.$ 'eva and Krot 1987). This value shows $\mathrm{Am}(\mathrm{OH})_{3}$ has the highest covalent "properties of all Am compounds studied by this method.: The An(III) hydroxides appear to be practically insoluble in water (see Table 2-4), but in crystal state are found to be easily peptized. The concentration of pseudo-soluble $\mathrm{Am}$ and $\mathrm{Cm}$ hydroxide sols may exceed $100 \mathrm{~g} / \mathrm{L}$ (Haire et al. 1977).

The solubility of Am(III) hydroxide was found to be constant in solution with $\mathrm{pH}$ ranging from 7 to 12 up to 3 to $5 \mathrm{M} \mathrm{NaOH}$ (Pazukhin and Kochergin 1989). Constant $1.6 \times 10^{-6} \mathrm{M}$ Am concentration in solution was attributed to the chemical speciation of americium as the neutral $\mathrm{Am}(\mathrm{OH})_{3}$ molecule.

Hydroxides of actinides in oxidation state $(+4)$, possessing the general composition $\mathrm{AnO}_{2} \cdot \mathrm{xH}_{2} \mathrm{O}$, have been reported for $\mathrm{U}, \mathrm{Np}, \mathrm{Pu}$ and $\mathrm{Am}$. U(IV), $\mathrm{Np}(\mathrm{IV})$, and $\mathrm{Pu}(\mathrm{IV})$ are prepared by neutralization of the corresponding acidic solutions. At the first step, $\mathrm{An}(\mathrm{OH})_{4}$ are formed. Then, polymerization takes place, especially in case of Pu(IV) hydroxide. The exposition of the system results in the aging of the solid phase, accompanied by partial dehydration. Aging of amorphous ${ }^{239} \mathrm{PuO}_{2} \cdot \mathrm{xH}_{2} \mathrm{O}$ does not result in complete crystallization (compared with Th(IV) hydroxide); instead, precipitates with an insignificant degree of crystallinity are formed (Rai and Ryan 1982). This is attributed to the suppressing effect of precipitate auto-radiolysis on the dehydration and crystallization processes. Aging of ${ }^{238} \mathrm{PuO}_{2} \cdot \mathrm{xH}_{2} \mathrm{O}$ in tridistilled water during a 1,300-day period was shown to result in formation of not only amorphous hydroxide, but also a highly disperse polymer phase (Rai and Ryan 1982). Along with $\mathrm{pH}$ reduction due to the radiolytic formation of nitric acid in the system, the presence of this polymer phase accounts for the high plutonium(IV) solubility observed in this study.

Taking into account the values of oxidation potentials reported in Section 2.2 for the $\mathrm{Am}(\mathrm{IV}) / \mathrm{Am}(\mathrm{III})$ and $\mathrm{O}_{2} / \mathrm{H}_{2} \mathrm{O}$ pairs in alkaline media, $\mathrm{Am}(\mathrm{OH})_{3}$ should undergo molecular $\mathrm{O}_{2}$ oxidation with Am(IV) formation. However, the rate of this heterogeneous process was found to be so small that it could hardly be noticed experimentally (Penneman et al. 1961). Hydrated americium oxide (most probably $\mathrm{AmO}_{2} \cdot \mathrm{xH}_{2} \mathrm{O}$ ) was found to be formed during oxidation of $\mathrm{Am}(\mathrm{OH})_{3}$ suspensions with $\mathrm{NaClO}$ in $0.2 \mathrm{M} \mathrm{NaOH}$ (Penneman et al. 1961; and Penneman and Asprey 1956), with $\mathrm{K}_{2} \mathrm{~S}_{2} \mathrm{O}_{8}$ in $7 \mathrm{M} \mathrm{NaOH}$ (Penneman et al. 1961; and Penneman and Asprey 1956), or with $\mathrm{H}_{2} \mathrm{O}_{2}$ in $\mathrm{KOH}$ solutions (Penneman and Asprey 1956; and Buijs and Louwrier 1966)).

An(IV) hydroxides are practically insoluble in water and in alkaline solutions (see Table 2-5). Nevertheless, in presence of $\mathrm{CO}_{3}^{2-}$ ions in alkaline solutions, soluble species of An(IV) may 
be prepared (Mefod'eva and Krot 1987). Moreover the solubility of $\mathrm{Np}(\mathrm{IV})$ in a $0.8 \mathrm{M}$ $\mathrm{Na}_{2} \mathrm{SO}_{4} / 0.8 \mathrm{M} \mathrm{NaOH}$ solution was reported to be $8.5 \times 10^{-6} \mathrm{M}$ (Cunningham and Hindman 1955).

Table 2-4. Selected Properties of An(III) Hydroxides.

\begin{tabular}{|c|c|c|c|c|}
\hline Compound & Color & Medium & $-\log \mathrm{K}_{\text {sP }}$ & References $^{\mathrm{a}}$ \\
\hline $\mathrm{Pu}(\mathrm{OH})_{3}$ & blue & $\mu=0$ & $\begin{array}{c}19.7 \\
26.2\end{array}$ & $\begin{array}{c}{[1]} \\
{[2]}\end{array}$ \\
\hline $\mathrm{Am}(\mathrm{OH})_{3}$ & light-pink & $\begin{array}{c}0.1 \mathrm{M} \\
\mathrm{NaClO}_{4}\end{array}$ & 25.7 & {$[3]$} \\
\hline & & $\begin{array}{c}0.003 \mathrm{M} \\
\mathrm{CaCl}_{2}\end{array}$ & 24.2 & {$[4]$} \\
\hline & & $\begin{array}{c}0.1 \mathrm{M} \\
\mathrm{NaClO}_{4}\end{array}$ & 24.8 & {$[5,6]$} \\
\hline & & $0.1 \mathrm{M}$ & 27.49 & {$[7]$} \\
& & $\mathrm{NaClO}_{4}$ & & {$[8]$} \\
\hline & & Calculated & 24.5 & {$[9]$} \\
\hline & & Calculated & 23.5 & {$[10]$} \\
\hline $\mathrm{Cm}(\mathrm{OH})_{3}$ & white & $\mu=3.0$ & 27.4 & {$[11]$} \\
\hline
\end{tabular}

'References:

[1] Katz and Seaborg 1957

[2] Felmy et al. 1989

[3] Stadler and Kim 1988

[4] Rai et al. 1983

[5] Silva 1982

[6] Silva 1983

[7] Bernkopf and Kim 1984

[8] Phillips 1982

[9] Allard 1982

[10] Pazukhin and Kochergin 1989

[11] Mefod'eva and Krot 1987

An(IV) hydroxides may exist as $\mathrm{An}(\mathrm{OH})_{4}, \mathrm{AnO}_{2} \cdot \mathrm{xH}_{2} \mathrm{O}, \mathrm{AnO}_{2}$ (cryst.), and $\mathrm{An}(\mathrm{OH})_{5}^{-}$ions. The solubility of actinide hydroxides in alkaline media in the presence of such complex forming agents as $\alpha$-oxycarbonic acids and aminocarboxylic acids has been reported (Myasoedov et al. 1980). 
$\mathrm{An}(\mathrm{V})$ hydroxides are known to possess slightly amphoteric properties. Their existence is reported for uranium, neptunium, plutonium, and americium. Soluble U(V) hydroxide has been prepared by electrochemical reduction of $\mathrm{U}(\mathrm{VI})$ in $\mathrm{NaOH}$ solutions. The solubility product of uranium(V) hydroxide is presented in Table 2-6 and is also available in Musicas and Rousset (1971).

$\mathrm{NpO}_{2} \mathrm{OH} \cdot \mathrm{xH}_{2} \mathrm{O}$ may be precipitated as a pale-green amorphous solid phase from acidic $\mathrm{Np}(\mathrm{V})$ solutions after addition of a small excess of ammonia or alkali (Cunningham and Hindman 1955). If the excess of alkali added to the $\mathrm{Np}(\mathrm{V})$ solution is too large, violet compounds of $\mathrm{NaNpO}_{2}(\mathrm{OH})_{2} \cdot \mathrm{xH}_{2} \mathrm{O}$ or $\mathrm{Na}_{2} \mathrm{NpO}_{2}(\mathrm{OH})_{3} \cdot \mathrm{xH}_{2} \mathrm{O}$ composition are formed (Visyascheva et al. 1984). The structures of these compounds are expected to consist of layers of $\mathrm{NpO}_{2}(\mathrm{OH})_{i}$ and $\mathrm{NpO}_{2}(\mathrm{OH})_{3}^{2-}$, correspondingly. $\mathrm{NpO}_{2}^{+}$ions in these layers are situated in the equatorial plane and are coordinated with $6 \mathrm{OH}^{-}$groups.

Reactions of $\mathrm{NpO}_{2}^{+}$ion with hydroxyl ions may be expressed by the equations:

$$
\begin{gathered}
\mathrm{NpO}_{2}^{+}+\mathrm{OH}^{-} \rightleftarrows \mathrm{NpO}_{2} \mathrm{OH} ; \beta_{1} \\
\mathrm{NpO}_{2}^{+}+2 \mathrm{OH}^{-} \rightleftarrows \mathrm{NpO}_{2}(\mathrm{OH})_{2}^{-} ; \beta_{2} \\
\mathrm{NpO}_{2}^{+}+3 \mathrm{OH}^{-} \rightleftarrows \mathrm{NpO}_{2}(\mathrm{OH})_{3}^{2-} ; \beta_{3}
\end{gathered}
$$

Existence of these forms was proved potentiometrically (see Section 2.4) and spectrophotometrically (Tananaev $1990 \mathrm{~b}$ ). The solubility product of $\mathrm{NpO}_{2} \mathrm{OH}$ and equilibrium constants for $\mathrm{Np}(\mathrm{V})$ anion formation in alkaline media are presented in Table 2-7.

Actinide solubility in aqueous alkaline solutions may be calculated according to the equation:

$$
[\mathrm{An}(\mathrm{V})]=\mathrm{K}_{\mathrm{sp}} \times\left[\mathrm{OH}^{-}\right]^{-1} \times\left(1+\beta_{1}\left[\mathrm{OH}^{-}\right]+\beta_{2}\left[\mathrm{OH}^{-}\right]^{2}+\ldots .+\beta_{\mathrm{n}}[\mathrm{OH}]^{-1}\right)
$$

For example, the solubility of $\mathrm{Np}(\mathrm{V})$ in $1 \mathrm{M} \mathrm{NaOH}$ was calculated as $1.3 \times 10^{-5} \mathrm{M}$ (Neck et al. 1992) or $1.2 \times 10^{-4} \mathrm{M}$ (Lierse et al. 1985). The solubilities of $\mathrm{Np}(\mathrm{V})$ hydroxide, determined experimentally, are presented in Table 2-7.

The addition of alkaline solutions to weakly acidic solutions of $\mathrm{Np}(\mathrm{V})$ may result in formation of alkaline $\mathrm{Np}(\mathrm{V})$ solutions with concentration up to (6 to 7) $\times 10^{-4} \mathrm{M}$ in $1 \mathrm{M}$ $\mathrm{NaOH}$ (Simakin et al. 1973). Such systems seem to be metastable. If tetraalkylammonium hydroxide solutions were used in such experiments, $\mathrm{Np}(\mathrm{V})$ concentration in the final solution was found to achieve more than $10^{-3} \mathrm{M}$ (Cohen and Fried 1969). 
The precipitate of $\mathrm{PuO}_{2} \mathrm{OH} \cdot \mathrm{xH}_{2} \mathrm{O}$ has been obtained by the addition of alkali to a freshly prepared weakly acidic solution of Pu(V) (Gel'man and Zaitseva 1964). The solubility product of this compound is presented in Table 2-6. Pale green compounds are formed upon reduction of $\mathrm{Pu}(\mathrm{VI})$ in $4 \mathrm{M} \mathrm{MeOH}(\mathrm{Me}=\mathrm{Li}, \mathrm{K}, \mathrm{Rb})$. The compounds are found to be isostructural with the corresponding $\mathrm{Np}(\mathrm{V})$ hydroxides with composition $\mathrm{MeNpO}_{2}(\mathrm{OH})_{2} \cdot \mathrm{xH}_{2} \mathrm{O}$. At alkali concentration was greater than $4 \mathrm{M}$, white compounds isostructural with $\mathrm{Me}_{2} \mathrm{NpO}_{2}(\mathrm{OH})_{3} \cdot \mathrm{xH}_{2} \mathrm{O}$ were reported to be formed (Tananeav 1992).

Table 2-5. Values of Solubility of Actinide (IV) Hydroxides in Different Media and their Solubility Products.

\begin{tabular}{|c|c|c|c|c|}
\hline Compound & Medium & $\begin{array}{c}\text { Solubility } \\
\text { M }\end{array}$ & $-\log \mathrm{K}_{\mathrm{SP}}$ & References $^{2}$ \\
\hline $\begin{array}{c}\mathrm{U}(\mathrm{OH})_{4} \\
\mathrm{UO}_{2} \cdot \mathrm{xH}_{2} \mathrm{O} \\
\mathrm{UO}_{2}(\mathrm{cr}) \\
\mathrm{UO}_{2} \cdot \mathrm{xH}_{2} \mathrm{O} \\
\mathrm{UO}_{2} \cdot \mathrm{xH}_{2} \mathrm{O}\end{array}$ & $\begin{array}{c}\mu=0.09-0.18 \\
0.045-1.0 \mathrm{LiOH} \\
1 \mathrm{M} \mathrm{NaOH} \\
\text { calculation } \\
\mu=0\end{array}$ & $\begin{array}{l}10^{-8} \\
10^{-14}\end{array}$ & $\begin{array}{c}51.96 \pm 0.22 \\
59.16 \pm 0.2 \\
52.6 \\
52.0 \pm 0.8\end{array}$ & $\begin{array}{l}{[1]} \\
{[2]} \\
{[3]} \\
{[3]} \\
{[4]} \\
{[5]}\end{array}$ \\
\hline $\begin{array}{c}\mathrm{Np}(\mathrm{OH})_{4} \\
\mathrm{~Np}(\mathrm{OH})_{4} \\
\mathrm{~Np}(\mathrm{OH})_{4} \\
\mathrm{~Np}(\mathrm{OH})_{4}(\mathrm{cr}) \\
\mathrm{NpO}_{2} \cdot \mathrm{xH}_{2} \mathrm{O} \\
\mathrm{NpO}_{2} \cdot \mathrm{xH}_{2} \mathrm{O}\end{array}$ & $\begin{array}{c}0.8 \mathrm{M} \mathrm{Na}_{2} \mathrm{SO}_{4} \\
0.8 \mathrm{M} \mathrm{NaOH} \\
\text { Calculation }\end{array}$ & $\begin{array}{l}8.5 \times 10^{-6} \\
5 \times 10^{-9}\end{array}$ & $\begin{array}{c}55.22 \\
53 \pm 2 \\
56 \\
54.5 \pm 0.3\end{array}$ & $\begin{array}{c}{[6]} \\
\\
{[7]} \\
{[8]} \\
{[9]} \\
{[10]} \\
{[4]}\end{array}$ \\
\hline $\begin{array}{c}\mathrm{Pu}(\mathrm{OH})_{4} \cdot \mathrm{xH}_{2} \mathrm{O} \\
\mathrm{Pu}(\mathrm{OH})_{4} \\
\mathrm{Pu}(\mathrm{OH})_{4} \\
\mathrm{Pu}(\mathrm{OH})_{4} \\
\mathrm{Pu}(\mathrm{OH})_{4} \\
\mathrm{Pu}(\mathrm{OH})_{4} \\
\mathrm{PuO}_{2} \cdot \mathrm{xH}_{2} \mathrm{O} \\
\mathrm{Pu}(\mathrm{OH})_{4}(\mathrm{am}) \\
\mathrm{Pu}(\mathrm{OH})_{4}(\mathrm{cr}) \\
\mathrm{Pu}(\mathrm{OH})_{4}\end{array}$ & $\begin{array}{l}\text { Calculation } \\
\begin{array}{c}\mu=0.288 \\
\mu=0.0033 \\
\mu=0.0003\end{array} \\
\mu=3\end{array}$ & & $\begin{array}{c}55.15 \\
52.0 \\
58.19 \\
51.06 \\
47.97 \\
50.2 \\
56.85 \pm 0.36 \\
57.82 \pm 0.17 \\
60.20 \pm 0.17 \\
51.43\end{array}$ & $\begin{array}{l}{[11]} \\
{[12]} \\
{[13]} \\
{[13]} \\
{[13]} \\
{[14]} \\
{[15]} \\
{[16]} \\
{[16]} \\
{[17]}\end{array}$ \\
\hline $\mathrm{AmO}_{2} \cdot \mathrm{xH}_{2} \mathrm{O}$ & Calculation & & 58.0 & [4] \\
\hline $\mathrm{CmO}_{2} \cdot \mathrm{xH}_{2} \mathrm{O}$ & Calculation & & 59.1 & [4] \\
\hline
\end{tabular}


Table 2-5. Values of Solubility of Actinide (IV) Hydroxides in Different Media and their Solubility Products.

\section{"References:}

[1] Stepanov and Galkin 1960

[2] Nikolaeva and Pirozshkov 1978

[3] Ryan and Rai 1983

[4] Rai et al. 1987

[5] Rai et al. 1990

[6] Cunningham and Hindman 1955

[7] Moskvin 1971

[8] Allard et al. 1980

[9] Lieser et al 1985

[10] Rai and Ryan 1985

[11] Connick 1955

[12] Latimer 1954

[13] Perez-Bustamante 1965

[14] Rai et al. 1980

[15] Rai 1984

[16] Kim and Kanellakopulos 1989

[17] Pazukhin and Kudryavtsev 1990 
Table 2-6. Solubility Products and Hydrolysis Constants of An(V).

\begin{tabular}{|c|c|c|c|c|c|}
\hline Actinide & $-\log \mathrm{K}_{\mathrm{sP}}$ & $\log \beta_{1}$ & $\log \beta_{2}$ & $\mu$ & References $^{*}$ \\
\hline $\mathrm{U}(\mathrm{V})$ & 9 & & & & {$[1]$} \\
\hline $\mathrm{Np}(\mathrm{V})$ & 9.0 & 3.92 & & 0.2 & {$[2]$} \\
& 9.73 & 5.1 & & 0.02 & {$[3]$} \\
& & 3.92 & & 1.0 & {$[4]$} \\
& & 4.68 & & 0.1 & {$[5]$} \\
& 9.2 & & & 1.0 & {$[6]$} \\
& 8.81 & 2.33 & 4.89 & 1.0 & {$[8]$} \\
& 9.85 & 3.18 & 5.15 & 3.0 & {$[9]$} \\
& 9.30 & 2.67 & 4.41 & 2.0 & {$[9]$} \\
& 8.56 & 2.44 & 4.10 & 0.1 & {$[9]$} \\
& 10.21 & 2.91 & 5.50 & 0.8 & {$[10]$} \\
& 8.94 & 2.67 & 5.74 & 0.1 & {$[10]$} \\
& 8.04 & & 5.16 & 0.012 & {$[10]$} \\
\hline $\mathrm{Pu}(\mathrm{V})$ & 8.8 & 4.6 & & 0 & {$[6]$} \\
& 9.3 & & & & {$[11]$} \\
\hline $\mathrm{Am}(\mathrm{V})$ & 9.3 & 1.7 & & 3.0 & {$[12]$} \\
\hline
\end{tabular}

"References

[1] Allard et al. 1980

[2] Moskvin 1971

[3] Sevostyanova and Khalturin 1976

[4] Vodovatov et al. 1976

[5] Maya 1983

[6] Kraus 1955

[7] Lierse et al. 1985

[8] Bidoglio et al. 1985

[9] Neck et al. 1992

[10] Itagaki et al. 1992

[11] Gel'man and Zaitseva 1964

[12] Stadler and Kim 1988 
Table 2-7. Solubilities of $\mathrm{Np}(\mathrm{V})$ in Different Basic Solutions

(Cunningham and Hindman 1955).

\begin{tabular}{|c|c|}
\hline Medium & Solubility, M \\
\hline Diluted $\mathrm{NH}_{4} \mathrm{OH}$ & $7.6 \times 10^{-4}$ \\
\hline $1 \mathrm{M} \mathrm{NaOH}$ & $7.2 \times 10^{-5}$ \\
\hline $2.2 \mathrm{M} \mathrm{NaOH}$ & $5.9 \times 10^{-5}$ \\
\hline
\end{tabular}

The equilibrium solubility of $\mathrm{Pu}(\mathrm{V})$ has not yet been determined. Taking into account that the hydrolytic behavior of $\mathrm{Np}(\mathrm{V})$ and $\mathrm{Pu}(\mathrm{V})$ are similar and both of them have similar values of solubility products, the value of about $1.0 \times 10^{-4} \mathrm{M}$ may be expected for $\mathrm{Pu}(\mathrm{V})$ solubility in $1 \mathrm{M} \mathrm{NaOH}$. As in case of $\mathrm{Np}(\mathrm{V})$, the preparation of concentrated $\mathrm{Pu}(\mathrm{V})$ alkaline solutions has been reported. For example, the UV-Vis spectrum of $4 \times 10^{-3} \mathrm{M} \mathrm{Pu}(\mathrm{V})$ solution in $4 \mathrm{M} \mathrm{NaOH}$ is presented (Bourges 1972).

The precipitation of $\mathrm{AmO}_{2} \mathrm{OH} \cdot \mathrm{xH}_{2} \mathrm{O}$ has been achieved by the addition of $\mathrm{NH}_{4} \mathrm{OH}$ or $\mathrm{KOH}$ to weakly acidic solutions of $\mathrm{Am}(\mathrm{V})$ (Zubarev and Krot 1982). The solubility product of this compound is presented in Table 2-6. In $0.86 \mathrm{M} \mathrm{NH}_{4} \mathrm{OH}$ solution, $\mathrm{Am}(\mathrm{V})$ concentration in equilibrium with solid $\mathrm{AmO}_{2} \mathrm{OH} \cdot \mathrm{xH}_{2} \mathrm{O}$ was found to be $0.22 \mathrm{~g} / \mathrm{L}$. Increase of the $\mathrm{NH}_{4} \mathrm{OH}$ concentration to $7 \mathrm{M}$ resulted in the corresponding increase of $\mathrm{Am}(\mathrm{V})$ concentration to $1.41 \mathrm{~g} / \mathrm{L}$ (Zubarev and Krot 1982). In KOH solution the reverse effect of alkali concentration has been observed: in $0.46 \mathrm{M} \mathrm{KOH}, \mathrm{Am}(\mathrm{V})$ concentration was found to be $0.029 \mathrm{~g} / \mathrm{L}$ and in $5.3 \mathrm{M} \mathrm{NaOH}$, less than $0.02 \mathrm{~g} / \mathrm{L}$ (Zubarev and Krot 1982).

The compounds $\mathrm{MeAmO}_{2}(\mathrm{OH})_{2} \cdot \mathrm{xH}_{2} \mathrm{O}(\mathrm{Me}=\mathrm{Li}, \mathrm{Na}, \mathrm{K})$ were found to be formed in 0.1 to $0.5 \mathrm{M}$ alkaline solutions. In $\mathrm{NaOH}$ or $\mathrm{KOH}$ solutions of less than $2 \mathrm{M} \mathrm{OH}^{-}$, $\mathrm{Me}_{2} \mathrm{AmO}_{2}(\mathrm{OH})_{3} \cdot \mathrm{xH}_{2} \mathrm{O}$ formation has been reported (Tananaev 1990a). These data prove the existence of such chemical forms of $\mathrm{Am}(\mathrm{V})$ as $\mathrm{AmO}_{2}(\mathrm{OH})_{2}\left(\mathrm{H}_{2} \mathrm{O}\right)_{2}^{-}$and $\mathrm{AmO}_{2}(\mathrm{OH})_{3}\left(\mathrm{H}_{2} \mathrm{O}\right)^{2-}$ in alkaline media (Tananaev 1992a).

Actinide(VI) hydroxides are reported for uranium, neptunium, plutonium, and americium. Alkaline metals and ammonium mono- and polyuranates are obtained by adding ammonia or the corresponding alkali to the aqueous uranyl solutions. In the reactions of uranates (polyuranates) with $\mathrm{H}_{2} \mathrm{O}_{2}$, peroxouranates are formed. Uranates are characterized by much lower solubility in aqueous solutions than corresponding peroxouranates (see Table 2-8 and [Weigel 1986]). The solubility of uranium(VI) hydroxide in $1 \mathrm{M} \mathrm{NaOH}$ equals $200 \mathrm{ppm}$ or $4 \times 10^{-4}$ M (Zantuti et al. 1991). 
Table 2-8. Solubility Products of An(VI) Hydroxides.

\begin{tabular}{|c|c|c|}
\hline Actinide & $-\log \mathrm{K}_{\mathrm{SP}}$ & References $^{\mathrm{c}}$ \\
\hline $\mathrm{U}(\mathrm{VI})$ & $22.7^{\mathrm{a}}$ & {$[1]$} \\
& $21.74^{\mathrm{b}}$ & {$[2]$} \\
& $22.4 \pm 0.2^{\mathrm{a}}$ & {$[3]$} \\
\hline $\mathrm{Np}(\mathrm{VI})$ & 22.7 & {$[4]$} \\
& $22.7 \pm 1.2$ & {$[3]$} \\
\hline $\mathrm{Pu}(\mathrm{VI})$ & 24.5 & {$[5]$} \\
& 22.75 & {$[6]$} \\
& $22.8 \pm 1$ & {$[3]$} \\
\hline
\end{tabular}

"calculated value

betermined experimentally in solution with $\mu=2$.

'References:

[1] Latimer 1954

[2] Babko and Kodenskaya 1960

[3] Allard et al. 1980

[4] Moskvin 1971

[5] Gel'man et al. 1961

[6] Moskvin and Zaitseva 1962

Plutonium(VI) hydroxides possess noticeable solubility in alkaline media (see Table 2-9).

Table 2-9. The Solubility of Plutonium(VI) Hydroxides in Alkaline Solutions of Different Concentrations (Perez-Bustamante 1965).

\begin{tabular}{|c|c|c|c|c|c|}
\hline$\left[\mathrm{OH}^{-}\right], \mathrm{M}$ & 0.11 & 1.00 & 2.00 & 5.00 & 10.0 \\
\hline $10^{5} \mathrm{x}[\mathrm{Pu}(\mathrm{VI})], \mathrm{M}$ & 1.05 & 3.24 & 4.36 & 6.98 & 10.3 \\
\hline
\end{tabular}

Addition of concentrated alkali to weakly acidic solution of $\mathrm{Np}(\mathrm{VI})$ or $\mathrm{Pu}(\mathrm{VI})$ yields solutions containing up to $0.01 \mathrm{M} \mathrm{Np}$ (VI) in $1 \mathrm{M} \mathrm{LiOH}$ and to $0.0075 \mathrm{M} \mathrm{Pu}(\mathrm{VI})$ in 1 to $3 \mathrm{M} \mathrm{NaOH}$ (Mefod'eva et al. 1977). When $\mathrm{Np}$ (VII) is reduced in alkaline media, metastable solutions of $\mathrm{Np}(\mathrm{VI})$ are formed. Electrochemical reduction of $\mathrm{Np}(\mathrm{VII})$ in $\mathrm{NaOH}$ results in the formation of $\mathrm{Np}$ (VI) solution with metal concentration 20 times higher than can be obtained by direct $\mathrm{Np}(\mathrm{VI})$ dissolution in alkali (Zielen and Cohen 1970).

Potentiometric measurements prove An(VI) to exist in alkaline media as $\mathrm{AnO}_{2}(\mathrm{OH})_{4}^{2-}$ (see Section 2.4). The same form is expected after consideration of results of spectrophotometric investigations $\mathrm{Np}(\mathrm{VI})$ and $\mathrm{Am}(\mathrm{VI})$ in alkaline solutions (Tananaev 1989). 
Hydroxides of actinides in oxidation state $(+7)$ are prepared only in the cases of $\mathrm{Np}, \mathrm{Pu}$, and Am. $\mathrm{AnO}_{4}(\mathrm{OH})_{2}^{3-}$ is known to be the common chemical form of An(VII) existence in alkaline media. Solid actinide(VII) compounds, however, may contain other structures. The preparation of $\mathrm{MeNpO}_{4}$ and $\mathrm{MeNpO}_{4} \cdot \mathrm{xH}_{2} \mathrm{O}\left(\mathrm{Me}=\mathrm{Li}, \mathrm{Na}, \mathrm{NH}_{4}\right)$ from solutions has been reported (Mefod'eva and Krot 1987). An(VII) compounds are soluble in water and aqueous alkaline solutions. It is possible to prepare $0.2 \mathrm{M} \mathrm{Np}$ (VII) solution in 2 to $3 \mathrm{M} \mathrm{LiOH}$ (Mefod'eva and Krot 1987).

The present review shows that actinide hydrous oxides in different oxidation states may exist in alkaline media as ions, neutral molecules, colloid and pseudocolloid particles, as well as solid phases. The solubility products of $A n(O H)_{3}$ and $A n(O H)_{4}$ are found to be so small that the concentration of $\mathrm{An}^{+3}$ and $\mathrm{An}^{+4}$ ions in alkaline solution, equilibrated with the solid hydroxide phase, should be rather small. Nevertheless, in the case of $\mathrm{Am}(\mathrm{III}), \mathrm{Am}(\mathrm{OH})_{3}$ molecules were proved to exist in the supernatant after separation of solid phase and colloid particles.

Potentiometric measurements have proved An(IV) to exist in alkaline solutions not only as $\mathrm{An}(\mathrm{OH})_{4}$ and $\mathrm{AnO}_{2} \cdot \mathrm{xH}_{2} \mathrm{O}$, but also as $\mathrm{An}(\mathrm{OH})_{5}^{-}$ions. An(V) exists as $\mathrm{AnO}_{2} \mathrm{OH}, \mathrm{AnO}_{2}(\mathrm{OH})_{2}$, $\mathrm{AnO}_{2}(\mathrm{OH})_{3}^{2-}$, and $\mathrm{AnO}_{2}(\mathrm{OH})_{4}^{3-} ; \mathrm{An}(\mathrm{VI})$ as $\mathrm{AnO}_{2} \mathrm{OH}^{+}, \mathrm{AnO}_{2}(\mathrm{OH})_{2}, \mathrm{AnO}_{2}(\mathrm{OH})_{3}^{-}, \mathrm{AnO}_{2}(\mathrm{OH})_{4}^{2-}$ or $\mathrm{AnO}_{4}\left(\mathrm{H}_{2} \mathrm{O}\right)_{2}^{2-;}$ and $\mathrm{An}(\mathrm{VII})$ as $\mathrm{AnO}_{4}(\mathrm{OH})_{2}^{3-}$.

\subsection{REFERENCES}

Allard, B., 1982, In Actinides in Perspective, N. M. Edelstein, Ed., Pergamon Press, New York, New York, p. 553.

Allard, B., H. Kipatzi, and J. O. Liljenzin, 1980, J. Inorg. Nucl. Chem., 42, No. 7, pp. 1015-1027.

Babko, A. K., and V. S. Kodenskaya, 1960., Zh. Neorg. Khim., 5, No. 11, pp. 2568-2574.

Berger, P., P. Blank, and J. Bourges, 1988, Radiochimica Acta, 43, No. 4, pp. 217-228.

Bernkopf, M., and J. I. Kim, 1984, Hydrolysis Reactions and Carbonate Complexation of Americium(III) in Natural Aquatic Systems, Report RCM-02884, Institut für Radiochemie, Technische Universität, Munich, Germany. Cited acc. Stadler and Kim 1988.

Bidoglio, G., G. Tanet, and A. Chatt, 1985, Radiochimica Acta, 38, No. 1, pp. 21-26.

Bondietti, E. A., and J. R. Trabalka, 1980, Radiochem. Radioanal. Lett., 42, No. 3, pp. 169-176.

Bourges, J., 1972, Radiochem. Radioanal. Lett., 12, No. 2-3, pp. 111-119. 
Bourges, J. Y., B. Guillaume, G. Koehly, D. E. Hobart, and J. R. Peterson, 1983, Inorg. Chem., 22, pp. 1179-1184.

Buijs, K., and K. R. Louwrier, 1966, J. Inorg, Nucl. Chem., 28, No. 10, pp. 2463-2464.

Cohen, D., and S. Fried, Inorg. Nucl. Chem. Lett., 1969, 5, No. 8, pp. 653-663.

Connick, R., 1955, in The Actinide Elements, G. T. Seaborg and J. J. Katz, Eds., Nauka Publ., Moscow, USSR, pp. 188-252. (Russian version). Published in English, 1954, Natl. Nucl. En. Ser., Div. IV, Vol. 14A, McGraw-Hill, New York, New York, pp. 221-300.

Cunningham, B., and J. Hindman, "Neptunium Chemistry," In The Actinide Elements, G. T. Seaborg, J. J. Katz, Eds., 1955, Moscow Foreign Literature Publ., Moscow, USSR, pp. 375-396 (Russian version). Published in English, 1954, Natl. Nucl. En. Ser., Div. IV, Vol. 14A, McGraw-Hill, New York, New York, chapter 12.

Delegard, C. H., 1987, Radiochimica Acta, 41, No. 1, pp. 11-21.

Deutsch, E., K. W. Heineman, R. Hurst, J. C. Sullivan, W. A. Mulac, and S. Gordon, 1978, Journal of Chem. Soc., Chem. Commun., p. 1038.

Ermakov, V. S., V. F. Peretrukhin, and N. N. Krot, 1977a, Radiokhimiya, 19, No. 2, p. 253.

Ermakov, V. S., V. F. Peretrukhin, and N. N. Krot, 1977b, Radiokhimiya, 19, No. 3, pp. 324-327.

Fedoseev, A. M., V. F. Peretrukhin, and N. N. Krot, 1979, Dokl. Akad. Nauk SSSR, 244, No. 5, pp. 1187-1190.

Felmy, A. R., D. Rai, J. A. Schramke, and J. L. Ryan, 1989, Radiochimica Acta, 48, No. $1 / 2$, pp. 29-35.

Founta, A., D. A. Aikens, and H. M. Clark, 1987, J. Electroanal. Chem., 129, pp. 221-246.

Frenkel, V. Ya., I. A. Lebedev, P. L. Khizshnyak, and B. F. Myasoedov, 1985a, Radiokhimiya, 27, No. 5, pp. 405-407.

Frenkel, V. Ya., I. A. Lebedev, P. L. Khizshnyak, and B. F. Myasoedov, 1985b, Radiokhimiya, 27, No. 5, pp. 576-581.

Gel'man, A. D., and V. P. Zaitseva, 1964, Dokl. Akad. Nauk SSSR, 157, No. 6, pp. 1403-1405. 
Gel'man, A.D., A. I. Moskvin, L. M. Zaitsev, and M. P. Mefod'eva, 1961, Komplekhsaye Soedineniya Transuranovykh Elementov, Academy of Sciences USSR Publ., Moscow, USSR, p. 293 (in Russian). Available in English as Complex Compounds of Transuranium Elements, 1962, Consultants Bureau, New York, New York.

Haire, R. G., M. H. Lloyd, W. O. Milligan, and M. L. Beasley, 1977, J. Inorg. Nucl. Chem., 39, No. 5, pp. 843-849.

Handbook on Chemistry, 1964, Nauka, Moscow, USSR, p. 3.

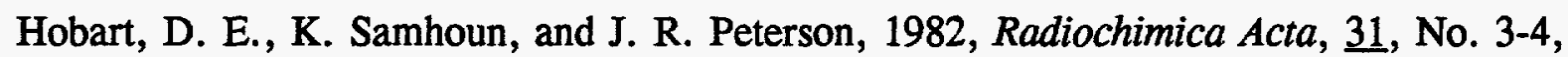
pp. 139-145.

Itagaki, H., Sh. Nakayama, S. Tanaka, and M. Yamawaki, 1992, Radiochimica Acta, $\underline{\mathbf{8 5 9}}$, No. 1, pp. 61-66.

Katz, J. J., and G. T. Seaborg, 1957, The Chemistry of Actinide Elements, Methuen and Co. Ltd. London, UK, J. Wiley and Sons, Inc., New York, New York, p. 229.

Katz, J. J., G. T. Seaborg and L. Morss, Eds., 1986a, The Chemistry of Actinide Elements, 2nd ed., Chapman and Hall Publishing, London, UK and New York, New York, Volume 1.

Katz, J. J., G. T. Seaborg and L. Morss, Eds., 1986b, The Chemistry of Actinide Elements, 2nd ed., Chapman and Hall Publishing, London, UK and New York, New York, Volume 2, p. 1143.

Kim, J. I., and B. Kanellakopulos, 1989, Radiochimica Acta, 48, No. 3/4, pp. 145-150.

Kraus, K. A., 1955, Proc. First Int. Conf. Peaceful Use of Atomic Energy, Geneve, Switzerland, 1956 A/Conf. 8, 73.

Kraus, K. A., 1949, in The Transuranium Elements, G. T. Seaborg, J. J. Katz, and W. M. Manning, Eds., Natl. Nucl. En. Ser., Paper 3.16, Div. IV, Vol.14B, McGraw-Hill Book Co., New York, New York, pp. 241-263.

Krot, N. N., A. D. Gel'man, M. P. Mefod'eva, V. P. Shilov, V. F. Peretrukhin, and V. I. Spitsyn, 1977, Semivalentnoe Sostoyanie Neptuniya, Plutoniya, Ameritsiya, Nauka Publ., Moscow, USSR, (in Russian) 152 p. Available in English as Heptavalent State of Neptunium, Plutonium and Americium UCRL-Trans-11798, Lawrence Livermore National Laboratory, Livermore, California.

Krot, N. N., M. P. Mefod'eva, V. P. Shilov, and A. D. Gel'man, 1970, Radiokhimiya, 12, No. 3, pp. 471-477. 
Latimer, W. M., 1954, Oxidation States of the Elements and Their Potentials in Aqueous Solutions, Foreign Literature Publ., Moscow, USSR, (in Russian). Second edition published in English, 1952, Prentice-Hall, Inc., New York, New York.

Latimer, W. M., 1954, ibid. p. 400 (in Russian).

Lierse, Ch., W. Treiber, and J. I. Kim, 1985, Radiochimica Acta, 38, No. 1, pp. 27-28.

Lieser, K. H., U. Mühlenweg, and I. Sipos-Galiba, 1985, Radiochimica Acta, $\underline{39}$, No. 1, pp. 35-41.

Martinot, L., and J. Fuger, 1985, "The Actinides" in Standard Potentials in Aqueous Solutions, A. J. Bard, R. Passons, and J. Jordan, Eds., Marcel Dekker Inc., New York, New York, Basel, Switzerland, pp. 650.

Maslennikov, A. G., V. F. Peretrukhin, and F. David, 1993, Proc. Finnish Russian Symp. on Radiochemistry, S. Kulmala, Ed., Helsinki, Finland, p. 12.

Maya, L., 1983, Inorg. Chem., 22, No. 14, pp. 2093-2095.

Mefod'eva, M. P., N. N. Krot, and T. V. Afonayeva, 1977, Radiokhimiya, 19, No. 2, pp. 245-249.

Mefod'eva, M. P., and N. N. Krot, 1987, Solid Compounds of Transuranium Elements, Nauka Publ., Moscow, USSR, 302 p. (in Russian).

Moskvin, A. I., 1971, Radiokhimiya, 13, No. 5, pp. 681-688.

Moskvin, A. I., and V. P. Zaitseva, 1962, Radiokhimiya, 4, No. 1, pp. 73-81.

Mulac, W. A., S. Gordon, K. N. Schmidt, D. Wester, and J. C. Sullivan, 1984, Inorg. Chem., 23, pp. 1639-1641.

Musicas, C., F. Couffin, and M. Marteau, 1974, J. Chem. Phys. et Chem. Phys. Biol., 71, No. 5, pp. 641-648.

Musicas, C., and G. Rousset, 1971, Note CEA, No. 1419, pp. 431-436.

Myasoedov, B. F., Z. K. Karalova, V. V. Nekrasova, and L. M. Rodionova, 1980, J. Inorg. Nucl. Chem., 42 , No. 10, pp. 1495-1499.

Neck, V., J. I. Kim, and B. Kanellakopulos, 1992, Radiochimica Acta, $\underline{56}$, No. 1, pp. 25-31. 
Nikolaeva, N. M., and A. V. Pirozshkov, 1978, Iz. Sib. Otd. Akad. Nauk SSSR, Ser. Khim., Iss. 5 , No. 12 , pp. 82-88.

Nikolayevsky, V. B., V. P. Shilov, N. N. Krot, and V. F. Peretrukhin, 1975a, Radiokhimiya, 17, No. 3, pp. 426-430.

Nikolayevsky, V. B., V. P. Shilov, N. N. Krot, and V. F. Peretrukhin, 1975b, Radiokhimiya, 17, No. 3, pp. 431-433.

Nikolayevsky, V. B., V. P. Shilov, and N. N. Krot, 1974, Radiokhimiya, 16, No. 1, pp. 122-123.

Nitsche, H., 1991, Radiochimica Acta, 52/53, Part 1, p. 3.

Pazukhin, E. M., and E. Kudryavtsev, 1990, Radiokhimiya, 32, No. 4, pp. 18-25.

Pazukhin, E. M., and S. M. Kochergin, 1989, Radiokhimiya, 31, No. 4, pp. 72-78.

Penneman, R. A., J. S. Coleman, and T. S. Keenan, 1961, J. Inorg. Nucl. Chem., 17, No. $1 / 2$, pp. $138-145$.

Penneman, R. A., and L. B. Asprey, 1956, "A Review of Americium and Curium Chemistry," in Proc. First Int'l. Conf. Peaceful Uses of Atomic Energy, Geneva, Switzerland, 1955, 7, p. 355.

Peretrukhin, V. F., F. David, and A. G. Maslennikov, 1994, Radiochimica Acta, 65, pp. 161-166.

Peretrukhin, V. F., and A. G. Maslennikov, 1992, in The Transuranium Elements, A Half Century, L. Morss and J. Fuger, Eds., ACS Publishing, New York, New York, p. 515.

Peretrukhin, V. F., and V. I. Spitsyn, 1982, Izv. Akad. Nauk SSSR, Ser. Khim., No. 4, pp. 826-831.

Peretrukhin, V. F., 1980, Electrochemical and Nuclear Chemical Reactions of Actinides in Solutions at High Oxidation and Reduction Potentials, Thesis for Professor Degree, p. 116, Institute of Physical Chemistry, Academy of Sciences USSR, Moscow, USSR (in Russian).

Peretrukhin, V. F., and D. P. Alekseeva, 1974a, Radiokhimiya, 16, No. 6, pp. 836-843.

Peretrukhin, V. F., and D. P. Alekseeva, 1974b, Radiokhimiya, 16, No. 6, pp. 843-849. 
Peretrukhin, V. F., V. B. Nikolayevsky, and V. P. Shilov, 1974, Radiokhimiya, 16, No. 6, pp. 833-836.

Peretrukhin, V. F., N. N. Krot., and A. D. Gel'man, 1972, Radiokhimiya, 14, No. 1, pp. $72-77$.

Perez-Bustamante, J. A., 1965, Radiochimica Acta, 4, No. 1, pp. 67-71.

Phillips, S. L., 1982, Hydrolysis and Formation Constants at $25^{\circ} \mathrm{C}$, Report LBL-14313, Lawrence Berkeley Laboratory, Berkeley, California. Cited acc. Stadler and Kim 1988.

Rabideau, S. V., L. B. Asprey, T. K. Keenan, and T. W. Newton, 1958, "Recent Advances in the Chemistry of Plutonium, Americium and Curium," in Proc. 2nd Int. Conf. Peaceful Uses of Nuclear Energy, Geneva, Switzerland.

Rai, D., Radiochimica Acta, 1984, 35, No. 2, pp. 97-102.

Rai, D., A. R. Felmy, and J. L. Ryan, 1990, Inorg. Chem., 29, No. 2, pp. 260-264.

Rai, D., and J. L. Ryan, 1985, Inorg. Chem., 24, No. 3, pp. 247-251.

Rai, D., and J. L. Ryan, 1982, Radiochimica Acta, 30, No. 4, pp. 213-216.

Rai, D., R. G. Strickert, D. A. Moore, and J. L. Ryan, 1983, Radiochimica Acta, 33, No. 4, pp. 201-206.

Rai, D., J. L. Swanson, and J. L. Ryan, 1987, Radiochimica Acta, 42, No. 1, pp. 35-40.

Rai, D., R. J. Serne, and D. A. Moore, 1980, Soil Sci. Soc. Am. J., 44, No. 4, pp. 490-496.

Ryan, J. L., and D. Rai, 1983, Polyhedron, 2, No. 9, pp. 947-952.

Sevostyanova, E. P., and G. V. Khalturin, 1976, Radiokhimiya, 18, No. 6, pp. 870-876.

Shilov, V. P., N. N. Krot, and A. D. Gel'man, 1970, Radiokhimiya, 12, No. 5 , pp. 697-699.

Silva, R. J., 1982, Thermodynamic Properties of Chemical Species in Nuclear Waste, Report LBL-15055, Lawrence Berkeley Laboratory, Berkeley, California. Cited acc. Stadler and $\operatorname{Kim} 1988$. 
Silva, R. J., 1983, The Behavior of Americium in Aqueous Carbonate Systems, Report LBL-16690, Lawrence Berkeley Laboratory, Berkeley, California. Cited acc. Stadler and $\operatorname{Kim} 1988$.

Simakin, G. A., 1977, Radiokhimiya, 19, No. 4, pp. 518-521.

Simakin, G. A., Yu. F. Volkov, T. I. Visyashcheva, I. I. Kopshokov, P. F. Baklonova, and G. N. Yakovlev, 1974, Radiokhimiya, 16, No. 6, pp. 859-863.

Simakin, G. A., N. V. Matyashchuk, and H. A. Vladimirova, 1973, Radiokhimiya, 15, No. 1 , pp. 98-100.

Spitsyn, V.I., and A. F. Kuzina, 1981, Technetium, Nauka Publ., Moscow, USSR, p. 187 (in Russian).

Spitsyn, V. I., and G. V. Ionova, 1978, Radiokhimiya, 20, No. 3, pp. 328-332.

Spitsyn, V. I., and G. V. Ionova, 1978, Dokl. Akad. Nauk SSSR, 241, No. 3, pp. 590-591.

Stadler, S., and J. I. Kim, 1988, Radiochimica Acta, 44/45, Part 1, pp. 39-41.

Stepanov, A. A., and N. P. Galkin, 1960, Atom. Energ., 9, No. 4, pp. 282-285.

Tananaev, I. G., 1992, Radiokhimiya, 34, No. 2, pp. 1-4.

Tananaev, I. G., 1990a, Radiokhimiya, 32, No. 4, pp. 4-6.

Tananaev, I. G., 1990b, Radiokhimiya, 32, No. 5, pp. 53-57.

Tananaev, I. G., 1989, Radiokhimiya, $\underline{31}$, No. 3, pp. 46-51.

Visyascheva, G. I., Yu. F. Volkov, G. A. Simakin, and I. I. Kapshukov, 1984, Radiokhimiya, 26, No. 2, pp. 171-176.

Vodovatov, V. A., V. B. Kolokoltsov, T. V. Kovaleva, L. G. Mashivrov, D. N. Suglobov, and V. G. Sles, 1976, in Transplutonium Elements, W. Muller and R. Lindner, Eds., North Holland Publ. Co., Amsterdam, Netherlands, p. 247.

Weigel, F., 1986, "Uranium" in The Chemistry of the Actinide Elements, J. J. Katz, G. T. Seaborg, and L. Morss, Eds., 2nd ed., Chapman and Hall Publishing, London, UK, and New York, New York, Volume 1, p. 276.

Zantuti, F., B. Al-Medehem, V. I. Silin, and V. F. Peretrukhin, 1991, Radioanal. Nucl. Chem. Articles, 147, No. 1, pp. 51-58. 
Zielen, A. J., and D. Cohen, 1970, J. Phys. Chem., 74, No. 2, pp. 394-405.

Zubarev, V. G., and N. N. Krot, 1982, Radiokhimiya, 24, No. 3, pp. 319-321. 


\subsection{REDOX REACTIONS OF ACTINIDES AND TECHNETIUM IN ALKALINE MEDIA AND PREPARATION OF ACTINIDES IN SELECTED OXIDATION STATES}

Redox reactions of actinides in alkaline media were studied primarily in the preparation of heptavalent neptunium, plutonium, and americium and for the reduction of heptavalent actinides by different reagents. In addition, the oxidation reactions of $\mathrm{Am}$ (III) and $\mathrm{Pu}$ (IV) in alkaline media were investigated.

\subsection{OXIDATION REACTIONS}

Different oxidizing agents were used in the oxidation reactions of actinides. The principal oxidizing agent studied is ozone. Other oxidizing agents include persulfate, hypobromite, hypochlorite, ferricyanide, xenon compounds, silver oxides, and permanganate.

\subsubsection{Oxidation by Ozone}

Ozone is one of the strongest oxidizing agents in alkaline media, $\mathrm{E}^{\circ}=1.24 \mathrm{~V}$ (NHE). Its potential is higher than the potentials of all the actinide pairs considered in Section 2.0.

3.1.1.1 Preparation of Neptunium(VII). The oxidation of suspensions of sodium or potassium neptunates in 0.5 to $5.0 \mathrm{M}$ alkalies by ozone was the initial method of neptunium(VII) preparation (Krot and Gel'man 1967; Krot et al. 1968). After some improvements this method has become the most effective procedure for the preparation of high purity neptunium(VII) solutions used in research practice.

The interaction of ozone with $\mathrm{Np}(\mathrm{VI})$ in alkaline media is a complex heterogeneous process dependent on many factors. The solution purity plays an important role (Krot et al. 1968). For example, $\mathrm{Np}$ (VI) oxidation can begin only after the complete decomposition of reducing agent impurities by ozone.

The kinetics of the reaction between ozone and $\mathrm{Np}(\mathrm{VI})$ strongly depends on the state of neptunium in alkaline media. When suspensions of neptunates in $\mathrm{NaOH}$ or $\mathrm{KOH}$ solutions are ozonized, the physical-chemical properties of the solid phase (in addition to the regime of $\mathrm{O}_{3}$ bubbling) have a considerable effect on the $\mathrm{Np}$ (VII) formation rate. Under otherwise similar conditions, the rate of $\mathrm{Np}(\mathrm{VI})$ oxidation increases with increasing surface area of the neptunate precipitate. The surface area depends on many diffusion-controlled factors. Because of the variability, data on the ozonation kinetics of neptunate suspensions are not reproducible, and only qualitative conclusions are possible. 
Note that long standing of precipitates leads to a decrease in the rate of $\mathrm{Np}$ (VI) oxidation because of the aging effect. Because of the aging, accumulation of $\mathrm{Np}$ (VII) by use of ozonation decreases with time and the complete dissolution of neptunates usually can not be reached. In this connection, the use of the $\mathrm{NpO}_{2} \mathrm{OH}$ suspension in $\mathrm{NaOH}$ solution instead of neptunates is interesting (Zielen and Cohen 1970). Upon ozonation, $\mathrm{Np}(\mathrm{V})$ is oxidized initially to $\mathrm{Np}(\mathrm{VI})$ and then to $\mathrm{Np}(\mathrm{VII})$.

The oxidation of $\mathrm{Np}(\mathrm{VI})$ in the form of the hydroxide precipitate in $\mathrm{NaOH}$ or $\mathrm{KOH}$ proceeds best in solutions with alkali concentration of 2 to $3 \mathrm{M}$. In solutions with other concentrations, the formation rate of $\mathrm{Np}$ (VII) is lower. This is due to the overlapping of two opposite effects: increase in the solubility of neptunates, and decrease in the solubility of $\mathrm{O}_{3}$ in the solution phase, with increase in alkali concentration.

The maximal concentration of $\mathrm{Np}(\mathrm{VII})$ attainable by the oxidation of neptunate suspensions in $\mathrm{NaOH}$ or $\mathrm{KOH}$ solutions is about 6 to $8 \mathrm{~g} / \mathrm{L}$. More concentrated solutions of $\mathrm{Np}(\mathrm{VII})$ can be prepared when LiOH is used (Blokhin et al. 1970). Solutions with Np(VII) concentration of about $30 \mathrm{~g} / \mathrm{L}$ may be produced by ozonation of neptunates in 2 to $3 \mathrm{M} \mathrm{LiOH}$. The higher concentrations can be explained by the higher solubility of lithium neptunates (Cohen and Fried 1969).

The kinetics of $\mathrm{Np}$ (VII) formation in dilute alkaline solutions free of neptunate precipitates is determined primarily by the rate of ozone supply and the intensity of mixing the phases; (i.e. by diffusion parameters) (Krot et al. 1968, Shashukov and Kozlov 1970, Mefod'eva et al. 1977). The rate of reaction between ozone and $\mathrm{Np}(\mathrm{VI})$ is controlled by kinetic parameters only at low concentrations of reagents $\left[0.1\right.$ to 0.5 vol. $\% \mathrm{O}_{3}$ in the gas mixture, (2 to 4) $\times 10^{-5} \mathrm{M} \mathrm{Np}(\mathrm{VI})$ in $\mathrm{KOH}$ solution] (Shashukov and Kozlov 1970). Under such conditions, the accumulation of $\mathrm{Np}$ (VII) is described by the equation:

$$
\left.\mathrm{dNp}(\mathrm{VII}) / \mathrm{dt}=\mathrm{k}[\mathrm{Np}(\mathrm{VI})]_{\left[\mathrm{O}_{3}^{\mathrm{gas}}\right.}\right]^{1 / 2}
$$

The constant $\mathrm{k}$ is equal to $0.59 \mathrm{~mol}^{-1 / 2} \mathrm{~L}^{3 / 2} \mathrm{~s}^{-1}$ for $1 \mathrm{M} \mathrm{KOH}$ and $20^{\circ} \mathrm{C}$. The $\mathrm{k}$ value increases with the decrease in alkali concentration. However, from these data it is impossible to determine the reaction order for hydroxide ions, because the solubility of $\mathrm{O}_{3}$ in the solution phase changes with the change in alkali concentration. In the same way, the complex temperature dependence of the $N p(V I)$ oxidation rate reflects a combination of the influence of temperature on the reaction of $\mathrm{Np}$ (VI) with the dissolved ozone and the distribution of ozone between the gas phase and the alkali solution.

At $\mathrm{Np}$ (VI) concentrations of about $10^{-2} \mathrm{M}$, the oxidation by ozone usually is in a kinetic regime controlled by diffusion parameters (Mefod'eva et al. 1977). Under these conditions, the rate of $\mathrm{Np}$ (VII) accumulation at constant rates of $\mathrm{O}_{3}$ supply and stirring intensity is typical for reactions of zero order:

$$
\mathrm{d}[\mathrm{Np}(\mathrm{VII})] / \mathrm{dt}=\mathrm{v}=\text { constant }
$$


The rate of $\mathrm{Np}(\mathrm{VI})$ oxidation is constant during the entire period required to complete the reaction.

Under otherwise similar conditions, the rate, $\mathrm{v}$, is proportional to $\left[\mathrm{O}_{3}^{\mathrm{gar}}\right]^{1 / 2}$. The dependence of the oxidation rate on $\mathrm{LiOH}$ concentration is described by a curve with a maximum. The rate of $\mathrm{Np}$ (VII) formation decreases with decrease in the alkali concentration, in spite of the increased solubility of $\mathrm{O}_{3}$ in the liquid phase. On this basis, it is possible to conclude that $\mathrm{Np}(\mathrm{VI})$ is oxidized not only by $\mathrm{O}_{3}$ but also by the products of its decomposition (e.g., by the ozonide ion, $\mathrm{O}_{3}^{-}$). The decomposition of $\mathrm{O}_{3}^{-}$by reducing agents is accelerated by decreasing alkali concentrations.

In spite of the decrease in the reaction rate, $\mathrm{Np}(\mathrm{VI})$ is oxidized by ozone even at pH 9 to 10 (Shilov 1977). Moreover, neptunium is converted partially to the heptavalent state upon ozonation of a $\mathrm{NpO}_{2} \mathrm{OH}$ suspension in water (Chaikhorsky 1974).

The completeness of $\mathrm{Np}(\mathrm{VI})$ oxidation depends upon the $\mathrm{Np}(\mathrm{VI})$ concentration. For instance, (2 to 4) $\times 10^{-5} \mathrm{M} \mathrm{Np}(\mathrm{VI})$ is oxidized to $80 \%$ completion (Shashukov and Kozlov 1970), and $3 \times 10^{-3} \mathrm{M} \mathrm{Np}$ (VI) to 98 to $100 \%$ completion (Mefod'eva et al. 1977).

3.1.1.2 Preparation of Plutonium(VII). Like Np(VII), heptavalent plutonium was originally prepared using ozone (Krot and Gel'man 1967; Komkov et al. 1968). Ozonation remains the principal method for the preparation of pure $\mathrm{Pu}(\mathrm{VII})$ solutions of different concentrations.

The interaction of $\mathrm{Pu}(\mathrm{VI})$ with ozone in alkaline media is similar to the oxidation of Np(VI) (Mefod'eva et al. 1977). The reaction rate in homogeneous solutions is determined by diffusion parameters. At sufficiently low concentrations of $\mathrm{Pu}(\mathrm{VI})$ and $\mathrm{O}_{3}$, it may be possible to find conditions at which the reaction rate will be within the kinetic region. However, no supporting experimental data exist.

The rate of $\mathrm{Pu}$ (VII) formation, when the $\mathrm{O}_{3}$ supply to the solution is constant, is described by an equation of zero order (Mefod'eva et al. 1977):

$$
\mathrm{d}[\mathrm{Pu}(\mathrm{VII})] \mathrm{dt}=\mathrm{v}=\text { constant }
$$

In solutions of alkalies containing hydroxide precipitates, the Pu(VI) oxidation occurs considerably faster than the $\mathrm{Np}$ (VI) oxidation. This effect is explained by the higher solubility of plutonates in $\mathrm{NaOH}$ solutions in comparison with neptunates.

The completeness of $\mathrm{Pu}(\mathrm{VI})$ oxidation in solutions with $\mathrm{OH}^{-}$concentrations less than $1 \mathrm{M}$ depends to some extent on the instability of $\mathrm{Pu}(\mathrm{VII})$; the rate of its reduction by water increases with decreasing $\mathrm{OH}^{-}$concentration (Krot et al. 1977a). 
3.1.1.3 Preparation of Americium(VII). The oxidation of Am(VI) can be carried out successfully in solutions with high concentration of hydroxide (Krot et al. 1974). However, the solubility of $\mathrm{O}_{3}$ decreases strongly at high concentration of $\mathrm{OH}^{-}$. Taking into account these opposite trends, it was determined that the optimal concentration of $\mathrm{OH}^{-}$for Am(VI) oxidation is about 3 to $4 \mathrm{M}$. Temperature also is an important parameter. The rate of Am(VII) reduction by water is decelerated on cooling while $\mathrm{O}_{3}$ solubility increases.

Therefore; lower temperatures favor Am(VII) formation. Finally, it is important to use pure solutions, because even low concentrations of impurities sharply decrease the stability of strong oxidizing agents in alkaline media.

It was established that 30 to 60 minutes of bubbling of a gas mixture with $\mathrm{O}_{3}$ concentrations of 20 to $50 \mathrm{mg} / \mathrm{L}$ through a cooled (to $0{ }^{\circ} \mathrm{C}$ ) solution of $\mathrm{Am}(\mathrm{VI})$ in 3 to $4 \mathrm{M} \mathrm{NaOH}$ leads to a change of the color and optical absorption spectrum of the solution. If a freshly-ozonized alkaline solution of americium is added to a stoichiometric excess of $\mathrm{Pu}(\mathrm{VI})$ in $1 \mathrm{M} \mathrm{NaOH}$ solution, the color characteristic of $\mathrm{Pu}(\mathrm{VII})$ appears almost instantly.

It has been shown that $\mathrm{Am}(\mathrm{VI})$ does not oxidize $\mathrm{Pu}(\mathrm{VI})$ in solutions with less than $3 \mathrm{M} \mathrm{NaOH}$ (Nikolaevsky 1974). The observed formation of $\mathrm{Pu}(\mathrm{VII})$ proves that Am(VI) is converted to Am(VII) by ozonation in alkaline solution:

$$
\mathrm{Pu}(\mathrm{VI})+\mathrm{Am}(\mathrm{VII}) \rightarrow \mathrm{Pu}(\mathrm{VII})+\mathrm{Am}(\mathrm{VI})
$$

The yield of Am(VII), evaluated by measurements of the formed Pu(VII) concentration, was 40 to $60 \%$. Similar results were obtained from study of the stoichiometry of the reaction:

$$
2 \mathrm{~Np}(\mathrm{VI})+\mathrm{Am}(\mathrm{VII}) \rightarrow 2 \mathrm{~Np}(\mathrm{VII})+\mathrm{Am}(\mathrm{V})
$$

3.1.1.4 Preparation of Americium(VI). Ozone oxidizes $\mathrm{Am}(\mathrm{OH})_{3}$ to $\mathrm{Am}(\mathrm{VI})$ at all $\mathrm{pHs}$ from neutral medium to $1 \mathrm{M} \mathrm{NaOH}$ (Penneman et al. 1961). In $1 \mathrm{M} \mathrm{NaOH}$, the oxidation occurs slowly; to increase the $\mathrm{O}_{3}$ solubility, it is necessary to work at $0^{\circ} \mathrm{C}$. At $25^{\circ} \mathrm{C}$, $\mathrm{Am}(\mathrm{OH})_{3}$ in $0.1 \mathrm{M} \mathrm{NaOH}$ is oxidized with moderate rate to $\mathrm{Am}(\mathrm{VI})$, a soluble yellow complex. In water, $\mathrm{Am}(\mathrm{OH})_{3}$ can be oxidized at $90^{\circ} \mathrm{C}$ by 1 to 2 hours bubbling of ozone. The $\mathrm{pH}$ upon ozonation should not be less than 5 .

The spectrum of the yellow complex of $A m(V I)$ is identical to the spectrum of the solution obtained upon the addition of alkali to an acid solution of $\mathrm{AmO}_{2}^{2+}$.

\subsubsection{Disproportionation of Neptunium(VI) and Americium(VI)}

Compared with the extensively-studied disproportionation reactions of tetra- and pentavalent actinides in acid solution, the disproportionations of hexavalent neptunium and americium in alkaline media are not well known. 
By electrochemical arguments, the necessary condition for the occurrence of the disproportionation of an element in the hexavalent state is the proximity of the potentials $E_{f}(V I I / V I)$ and $E_{f}(V I / V)$. In the case of neptunium and americium, the potentials of the mentioned pairs in $1 \mathrm{M} \mathrm{NaOH}$ differ by about $0.4 \mathrm{~V}$. The value of $\mathrm{E}_{\mathrm{f}}$ (VII/VI) decreases strongly with increasing alkali concentration, whereas the value of $\mathrm{E}_{\mathrm{f}}$ (VI/V) changes slightly. Therefore, at greater than $10 \mathrm{M} \mathrm{NaOH}$, penta-, hexa- and heptavalent states of neptunium or americium can coexist.

Experimental tests have shown that rapid 10 to 20 -fold dilution of a colorless $5 \times 10^{-3} \mathrm{M}$ solution of $\mathrm{Np}(\mathrm{VI})$ with $17 \mathrm{M} \mathrm{NaOH}$ leads to the appearance of the green color characteristic of $\mathrm{Np}$ (VII) (Krot et al. 1970). The optical absorption spectrum of the solution in the visible region after the removal of air bubbles is close to the spectrum of $\mathrm{Np}$ (VII). A difference in the absorbance over the wavelength region occurs because of the presence of $\mathrm{Np}(\mathrm{VI})$.

The equilibrium:

$$
2 \mathrm{~Np}(\mathrm{VI}) \rightleftarrows \mathrm{Np}(\mathrm{VII})+\mathrm{Np}(\mathrm{V})
$$

is achieved at room temperature in less than one minute. The equilibrium position strongly depends on the $\mathrm{NaOH}$ concentration. Neptunium(VII) is practically not formed in solutions with less than $9 \mathrm{M} \mathrm{NaOH}$. The yield of $\mathrm{Np}$ (VII) increases sharply with increasing alkali concentration to $17 \mathrm{M}$. The values of the equilibrium constant, $\mathrm{K}_{6}=[\mathrm{Np}(\mathrm{VII})][\mathrm{Np}(\mathrm{V})] /[\mathrm{Np}(\mathrm{VI})]^{2}$, are shown in Table $3-1$.

The disproportionation of $\mathrm{Np}(\mathrm{VI})$ was also studied in the case of hot solutions of $\mathrm{NaOH}$ (in which neptunates are more soluble than at room temperature) (Ermakov et al. 1977). Because the viscosity of the alkali solutions decreases with increasing temperature and, as a consequence, air bubbles are easily removed, well-reproducible values of the equilibrium constant could be obtained.

The $\mathrm{K}_{6}$ values under the studied conditions are not temperature dependent. Hence, the activation energy for the disproportionation of $\mathrm{Np}(\mathrm{VI})$ and the reduction of $\mathrm{Np}$ (VII) by $\mathrm{Np}(\mathrm{V})$ are equal within experimental error.

Disproportionation was studied for $\mathrm{KOH}$ and $\mathrm{CsOH}$ aqueous solutions and also for water-ethanol solutions of $\mathrm{KOH}$ (Tananaev 1991). The nature of alkali plays a low role, whereas the decrease in the water content favors disproportionation. For example, in a solution containing 60 vol. \% $\mathrm{CH}_{3} \mathrm{OH}$, disproportionation occurs to noticeable extent in $4 \mathrm{M} \mathrm{KOH}$. 
Table 3-1. Disproportionation of $\mathrm{Np}(\mathrm{VI})$ in $\mathrm{NaOH}$ Solutions (at 21 to $23{ }^{\circ} \mathrm{C}$ ).

\begin{tabular}{|c|c|c|c|c|}
\hline$[\mathrm{NaOH}], \mathrm{M}$ & {$[\mathrm{Np}(\mathrm{VI})]_{0} \times 10^{4}, \mathrm{M}$} & {$[\mathrm{Np}(\mathrm{V})]_{0} \times 10^{4}, \mathrm{M}$} & {$[\mathrm{Np}(\mathrm{VII})] \times 10^{5}, \mathrm{M}$} & $\mathrm{K}_{6} \times 10^{2}$ \\
\hline 8.7 & 9.52 & - & 1.2 & $1.7 \times 10^{-2}$ \\
\hline 10.7 & 9.52 & - & 3.5 & 0.16 \\
\hline 11.8 & 2.38 & - & 1.4 & 0.44 \\
\hline 12.4 & 5.00 & - & 3.8 & 0.8 \\
\hline 13.6 & 2.38 & - & 2.8 & 2.4 \\
\hline 14.8 & 4.55 & - & 7.8 & 6.8 \\
\hline 15.3 & 2.38 & - & 4.3 & 8.0 \\
\hline 17.2 & 2.38 & - & 5.1 & 13.2 \\
\hline 13.6 & 2.38 & 0.33 & 1.8 & 2.2 \\
\hline 13.6 & 2.38 & 0.84 & 1.5 & 3.4 \\
\hline 13.6 & 2.38 & 2.50 & 0.45 & 2.5 \\
\hline
\end{tabular}

Disproportionation of Am(VI) has been observed (Nikolaevsky 1975). In a quartz cell, 2.5 to $3.0 \mathrm{~mL}$ of cooled (to $0^{\circ} \mathrm{C}$ ) $18 \mathrm{M} \mathrm{NaOH}$ were mixed with $0.2 \mathrm{~mL}$ of cooled slightly-acid $3 \times 10^{-2} \mathrm{M} \mathrm{Am(VI).} \mathrm{The} \mathrm{optical} \mathrm{absorption} \mathrm{spectrum} \mathrm{of} \mathrm{the} \mathrm{resulting} \mathrm{solution}$ had a band with a peak at 740 to $750 \mathrm{~nm}$ characteristic of Am(VII). Because there were no other oxidizing agents in the solution, the formation of Am(VII) was possible only as a result of the disproportionation of $\mathrm{Am}(\mathrm{VI})$ :

$$
2 \mathrm{Am}(\mathrm{VI}) \rightleftarrows \mathrm{Am}(\mathrm{VII})+\mathrm{Am}(\mathrm{V})
$$

The approximate values of $\mathrm{K}_{7}\left(=[\mathrm{Am}(\mathrm{VII})][\mathrm{Am}(\mathrm{V})] /[\mathrm{Am}(\mathrm{VI})]^{2}\right)$ are shown in Table 3-2.

Disproportionation of $A m(V I)$ is slightly more extensive than that of $N p(V I)$ at a given $\mathrm{NaOH}$ concentration. However, in both cases, features of influence of the $\mathrm{NaOH}$ concentration on the equilibrium are the same. 
Table 3-2. Disproportionation of $\mathrm{Am}(\mathrm{VI})$ in $\mathrm{NaOH}$ Solutions (at 0 to $3{ }^{\circ} \mathrm{C}$ ).

\begin{tabular}{|c|c|c|c|}
\hline$[\mathrm{NaOH}], \mathrm{M}$ & {$[\mathrm{Am}(\mathrm{VI})] \times 10^{3}, \mathrm{M}$} & {$[\mathrm{Am}(\mathrm{VII})] \times 10^{4}, \mathrm{M}$} & $\mathrm{K}_{7}$ \\
\hline 8.5 & 1.74 & Not detected & - \\
\hline 12.4 & 1.61 & 2.0 & $2.8 \times 10^{-2}$ \\
\hline 14.2 & 2.04 & 3.4 & $6.3 \times 10^{-2}$ \\
\hline 15.4 & 2.30 & 8.0 & 1.3 \\
\hline 16.6 & 1.37 & 4.5 & 0.9 \\
\hline 17.2 & 1.39 & 6.1 & 13.0 \\
\hline
\end{tabular}

\subsubsection{Oxidation by Persulfate}

Persulfate, $\mathrm{S}_{2} \mathrm{O}_{8}^{2-}$, was used to oxidize transuranium elements to higher valent states.

3.1.3.1 Preparation of Neptunium(VII). The interaction of $\mathrm{Np}(\mathrm{VI})$ with $\mathrm{S}_{2} \mathrm{O}_{8}^{2-}$ in alkaline solutions is a complex process; under certain conditions, Np(VII) may be formed (Spitsyn et al. 1968; Shilov et al. 1971). The mechanism of the process has been studied in $\mathrm{NaOH}$ solutions having low concentrations $\left(2.5 \times 10^{-4} \mathrm{M}\right)$ of $\mathrm{Np}(\mathrm{VI})$ (Shilov et al. 1971).

The experiments have shown that the oxidation of $\mathrm{Np}(\mathrm{VI})$ by persulfate should be carried out in solutions with low concentration of alkali. At 0.1 to $0.7 \mathrm{M} \mathrm{NaOH}$ and $0.1 \mathrm{M} \mathrm{K}_{2} \mathrm{~S}_{2} \mathrm{O}_{8}$, a moderate rate of reaction is ensured by heating the solution to more than $50{ }^{\circ} \mathrm{C}$. Under these conditions, the oxidation proceeds to completion. Kinetic curves are linear almost to completion; i.e., the reaction is zero order with respect to $\mathrm{Np}(\mathrm{VI})$ :

$$
-\mathrm{d}[\mathrm{Np}(\mathrm{VI})] / \mathrm{dt}=\mathrm{d}[\mathrm{Np}(\mathrm{VII})] / \mathrm{dt}=\text { constant }
$$

Toward the end of the reaction, $\mathrm{Np}(\mathrm{VI})$ interacts with the $\mathrm{S}_{2} \mathrm{O}_{8}^{2-}$ decomposition products. The rate of the decomposition products' formation does not depend on the $\mathrm{Np}$ (VI) concentration. Therefore, the rate of formation of the decomposition products is constant during the entire experiment, because during this period the $\mathrm{S}_{2} \mathrm{O}_{8}^{2-}$ concentration changes slightly.

The first step of the process at low concentration of $\mathrm{NaOH}$ (as in neutral solutions) is the decomposition of $\mathrm{S}_{2} \mathrm{O}_{8}^{2-}$ (Kolthoff and Miller 1951):

$$
\mathrm{S}_{2} \mathrm{O}_{8}^{2-} \rightarrow 2 \mathrm{SO}_{4}^{-}
$$

The further fast reactions in alkaline solutions give rise to the formation of $\mathrm{O}_{3}^{-}$radical ions; they convert $\mathrm{Np}$ (VI) to $\mathrm{Np}(\mathrm{VII})$ (Gogolev et al. 1989): 


$$
\begin{gathered}
\mathrm{SO}_{4}^{-}+\mathrm{OH}^{-} \rightarrow \mathrm{SO}_{4}^{2-}+\mathrm{OH}, \\
\mathrm{OH}+\mathrm{OH}^{-} \rightleftarrows \mathrm{O}^{-}+\mathrm{H}_{2} \mathrm{O}, \\
\mathrm{O}_{2}+\mathrm{O}^{-} \rightarrow \mathrm{O}_{3}^{-}, \\
\mathrm{Np}(\mathrm{VI})+\mathrm{O}_{3}^{-} \rightarrow \mathrm{Np}(\mathrm{VII})+\mathrm{O}_{2}+\mathrm{O}^{2-}
\end{gathered}
$$

The $\mathrm{SO}_{4}^{-}$radical ions also may react directly with $\mathrm{Np}(\mathrm{VI})$ :

$$
\mathrm{Np}(\mathrm{VI})+\mathrm{SO}_{4}^{-} \rightarrow \mathrm{Np}(\mathrm{VII})+\mathrm{SO}_{4}^{2-}
$$

However, the reaction described by equation 10 is more probable, because it occurs with a sufficiently high rate $\left(\mathrm{k}_{10}=4.3 \times 10^{7} \mathrm{M}^{-1} \mathrm{~s}^{-1}\right.$ [Hart and Anbar 1970]). It is unlikely that $\mathrm{k}_{14}$ is much higher; at the same time, the $\mathrm{OH}^{-}$concentration exceeds the $\mathrm{Np}$ (VI) concentration by about 3 orders of magnitude.

The kinetics of the $\mathrm{K}_{2} \mathrm{~S}_{2} \mathrm{O}_{8}$ decomposition in dilute alkali solutions is described by an equation for a first-order reaction (Kolthoff and Miller 1951). The same order via persulfate should also apply to the oxidation of $\mathrm{Np}(\mathrm{VI})$; i.e.

$$
\mathrm{v}=\mathrm{d}[\mathrm{Np}(\mathrm{VII})] / \mathrm{dt}=\mathrm{k}\left[\mathrm{S}_{2} \mathrm{O}_{8}^{2-}\right]
$$

The $\mathrm{k}$ values shown in Table 3-3, under otherwise similar conditions, are constant over a wide range of the $\mathrm{K}_{2} \mathrm{~S}_{2} \mathrm{O}_{8}$ concentrations.

The rate constant of the $\mathrm{S}_{2} \mathrm{O}_{8}^{2-}$ decomposition in $0.1 \mathrm{M} \mathrm{NaOH}$ at $60^{\circ} \mathrm{C}$ is $3 \times 10^{-4} \mathrm{~min}^{-1}$ (Kolthoff and Miller 1951). The rate of $\mathrm{Np}$ (VII) accumulation under these conditions is about $2.1 \times 10^{-5} \mathrm{M} \mathrm{min}^{-1}$. Therefore, not all $\mathrm{SO}_{4}^{-}$radical ions formed from the $\mathrm{S}_{2} \mathrm{O}_{8}^{2-}$ decomposition are consumed for the $\mathrm{Np}$ (VII) formation. Probably, as in the case of the oxidation by ozone, it is due to the decomposition of $\mathrm{O}_{3}^{-}$in the dilute alkali solution (Gogolev et al. 1989). 
Table 3-3. Kinetic Parameters of Np(VI) Oxidation at Different Concentrations of $\mathrm{S}_{2} \mathrm{O}_{8}^{2-}\left([\mathrm{Np}(\mathrm{VI})]_{0}=2.3 \times 10^{-4} \mathrm{M}\right.$; $\mu=2.0 \mathrm{M} ;\left[\mathrm{OH}^{-}\right]=0.2 \mathrm{M}, 60^{\circ} \mathrm{C}$ ).

\begin{tabular}{|c|c|c|}
\hline$\left[\mathrm{S}_{2} \mathrm{O}_{8}^{2-}\right] \times 10^{2}, \mathrm{M}$ & $\mathrm{v} \times 10^{6}, \mathrm{M} \min ^{-1}$ & $\mathrm{k} \times 10^{4}, \min ^{-1}$ \\
\hline 2.5 & 5.0 & 2.0 \\
\hline 5 & 10.0 & 2.0 \\
\hline 10 & 21.1 & 2.1 \\
\hline 20 & 42.2 & 2.1 \\
\hline 30 & 59.5 & 2.0 \\
\hline
\end{tabular}

The concentration of alkali considerably influences the rate of accumulation and the yield of $\mathrm{Np}(\mathrm{VII})$. At $60^{\circ} \mathrm{C}$ and $2.0 \mathrm{M}$ ionic strength $(\mu)$, the rates of $\mathrm{Np}(\mathrm{VI})$ oxidation in 0.1 and $0.2 \mathrm{M} \mathrm{NaOH}$ are practically identical. Increase in the alkali concentration to $0.9 \mathrm{M}$ leads to a decrease in the reaction rate. In $1 \mathrm{M} \mathrm{NaOH}$, the rate decreases further; $\mathrm{Np}$ (VII) concentration also decreases later in the reaction, and thus the kinetic curve for the $\mathrm{Np}$ (VII) formation has a maximum. A maximum reaction rate is also observed at higher concentrations of alkali only the maximum appears earlier and its height is less. In $1 \mathrm{M} \mathrm{NaOH}$ at 70 and $80^{\circ} \mathrm{C}$, the yield of $\mathrm{Np}$ (VII) reaches the same value as in solutions with lower concentrations of alkali; however with time, the $\mathrm{Np}(\mathrm{VII})$ concentration begins to decrease.

All the above-mentioned features of the process are caused by the mechanism of $\mathrm{S}_{2} \mathrm{O}_{8}^{2-}$ decomposition. It is quite probable that the decomposition proceeds via two pathways; one of them is non-catalytic and the second is catalytic, with the participation of $\mathrm{OH}^{-}$. The decay of persulfate upon the action of $\mathrm{OH}^{-}$ions proceeds with the formation of reducing agents (for example, $\mathrm{H}_{2} \mathrm{O}_{2}$ ). Such a pathway becomes predominant at 3 to $4 \mathrm{M} \mathrm{NaOH}$.

Increase in the alkali concentration to 5 to $6 \mathrm{M}$ again gives rise to $\mathrm{Np}$ (VII) formation. Apparently, under such conditions there is a further change in the mechanism of $\mathrm{S}_{2} \mathrm{O}_{8}^{2-}$ decomposition.

The rate of $\mathrm{Np}$ (VI) oxidation in $0.2 \mathrm{M} \mathrm{NaOH}$ depends slightly upon ionic strength, $\mu$, within the range of 0.5 to 2.0 molar. In $0.7 \mathrm{M} \mathrm{NaOH}$, the rate constant decreases with increasing $\mu$, and at a $\mu$ of 3.1, the kinetic curve has a maximum; i.e., the process has the same features as in the case of $1 \mathrm{M} \mathrm{NaOH}$ with $\mu=2.0$.

The activation energy of the reaction between $\mathrm{Np}(\mathrm{VI})$ and $\mathrm{S}_{2} \mathrm{O}_{8}^{2-}$ in solutions with $0.7 \mathrm{M} \mathrm{OH}^{-}$ and $1 \mathrm{M}$ ionic strength $(\mu)$ is $140 \mathrm{~kJ} \mathrm{~mol}^{-1}$. This value coincides with the value of the activation energy for the non-catalytic decomposition of $\mathrm{S}_{2} \mathrm{O}_{8}^{2-}$ (Kolthoff and Miller 1951). 
The influence of hydroxides of some transition metals on $\mathrm{Np}$ (VI) oxidation by persulfate was studied. It was found that in $4 \mathrm{M} \mathrm{NaOH}$, the addition of salts of the following metals at the indicated concentrations:

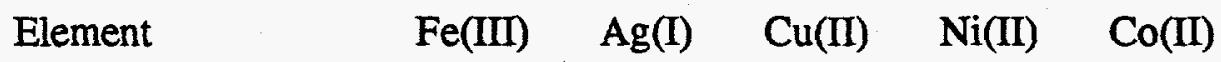

Concentration, $\mathbf{M}$

$$
5 \times 10^{-5} \quad 1 \times 10^{-5} \quad 5 \times 10^{-6} \quad 1 \times 10^{-7} \quad 2 \times 10^{-8}
$$

caused the oxidation of $\mathrm{Np}(\mathrm{VI})$ to $\mathrm{Np}(\mathrm{VII})$ even at room temperature. Products having oxidizing properties are clearly formed on the catalytic decomposition of persulfate.

It is noteworthy that $\mathrm{Np}$ (VII) solutions containing $\mathrm{Ni}$ and Co compounds discolor on standing for 15 to 20 hours. Apparently, during this time, the catalysts coagulate in $4 \mathrm{M} \mathrm{NaOH}$ and are precipitated. As a result, their catalytic action disappears, and $\mathrm{Np}$ (VII) is gradually reduced. The added $\mathrm{Ag}(\mathrm{I})$, however, retains its catalytic properties even through 24 hours.

The catalytic action of salts of transition metals changes somewhat in dilute alkali solutions. In $0.5 \mathrm{M} \mathrm{NaOH}$, iron and copper at concentrations to $5 \times 10^{-5} \mathrm{M}$ have slight influence on the oxidation process. The action of nickel becomes noticeable at concentrations of $5 \times 10^{-6} \mathrm{M}$. Silver and cobalt compounds have the same catalytic activity as nickel.

3.1.3.2 Preparation of Plutonium(VII). The interaction of $\mathrm{Pu}(\mathrm{VI})$ with $\mathrm{S}_{2} \mathrm{O}_{8}^{2-}$ has been studied in $\mathrm{KOH}$ solutions (Komkov et al. 1969). In many aspects, this process is similar to the oxidation of $\mathrm{Np}(\mathrm{VI})$ by persulfate in $\mathrm{NaOH}$ solutions.

The formation of $\mathrm{Pu}$ (VII) in 0.2 to $1.0 \mathrm{M} \mathrm{KOH}$ at 0.02 to $0.15 \mathrm{M} \mathrm{K}_{2} \mathrm{~S}_{2} \mathrm{O}_{8}$ proceeds at an appreciable rate at 70 to $95^{\circ} \mathrm{C}$. The reaction rate initially is independent of the $\mathrm{Pu}(\mathrm{VI})$ concentration, but it is proportional to the concentration of oxidizing agent. The accumulation of $\mathrm{Pu}$ (VII) is described by an equation of zero order with respect to actinide and first order with respect to $\mathrm{S}_{2} \mathrm{O}_{8}^{2-}$, as in the case of $\mathrm{Np}$ (VI) oxidation:

$$
\mathrm{v}=\mathrm{d}[\mathrm{Pu}(\mathrm{VII})] / \mathrm{dt}=-\mathrm{d}[\mathrm{Pu}(\mathrm{VI})] / \mathrm{dt}=\mathrm{k}\left[\mathrm{S}_{2} \mathrm{O}_{8}^{2-}\right]
$$

The reaction rate increases with increasing temperature. The activation energy in $1 \mathrm{M} \mathrm{KOH}$ is $143 \mathrm{~kJ} \mathrm{~mol}^{-1}$; within the limits of experimental error it coincides with the respective value for the thermal decomposition of $\mathrm{S}_{2} \mathrm{O}_{8}^{2-}$ (Kolthoff and Miller 1951). Hence, it is possible to confirm that both the oxidation of $\mathrm{Pu}(\mathrm{VI})$ and the oxidation of $\mathrm{Np}(\mathrm{VI})$ proceed by way of a mechanism with the participation of $\mathrm{O}_{3}^{-}$and/or $\mathrm{SO}_{4}^{-}$which are formed upon $\mathrm{S}_{2} \mathrm{O}_{8}^{2-}$

decomposition. However, the formation of $\mathrm{Pu}$ (VII) is complicated by its instability in 
aqueous solutions, especially at low $\mathrm{OH}^{-}$concentrations and elevated temperatures. The reduction of $\mathrm{Pu}(\mathrm{VII})$, in addition to the oxidation of $\mathrm{Pu}(\mathrm{VI})$, occurs more rapidly in hot solutions of $\mathrm{KOH}$.

Because of the competing reactions, the oxidation of $\mathrm{Pu}(\mathrm{VI})$ cannot be complete. A steady state, in which the rates of the oxidation of $\mathrm{Pu}(\mathrm{VI})$ and the reduction of $\mathrm{Pu}(\mathrm{VII})$ are equal, is achieved after some period of time. The position of this steady state, i.e. the yield of $\mathrm{Pu}(\mathrm{VII})$, depends on the temperature and concentrations of $\mathrm{OH}^{-}$and $\mathrm{S}_{2} \mathrm{O}_{8}^{2-}$.

Increase in temperature leads to an increase in the formation rate and the completeness of the $\mathrm{Pu}(\mathrm{VI})$ oxidation. This is because the activation energy of the reaction between $\mathrm{Pu}(\mathrm{VI})$ and $\mathrm{S}_{2} \mathrm{O}_{8}^{2-}$ is considerably higher than the activation energy of the reduction of $\mathrm{Pu}(\mathrm{VII})$ by water (which is $60.6 \mathrm{~kJ} \mathrm{~mol}^{-1}$ [Komkov and Krot 1970]).

Increase in the $\mathrm{KOH}$ concentration from 0.2 to $0.5 \mathrm{M}$ leads to some increase in the oxidation rate of $\mathrm{Pu}(\mathrm{VI})$; above $0.5 \mathrm{M} \mathrm{KOH}$, the rate decreases. The yield of $\mathrm{Pu}(\mathrm{VII})$ increases linearly up to $1 \mathrm{M} \mathrm{KOH}$ concentration; above $1 \mathrm{M} \mathrm{KOH}$, the yield decreases sharply. Obviously, at low concentration of $\mathrm{KOH}$, the rate of the $\mathrm{Pu}$ (VII) reduction by water is high, and its yield is small. The stability of $\mathrm{Pu}(\mathrm{VII})$ increases with increasing $\mathrm{OH}^{-}$concentration and its yield increases. As in the case of $\mathrm{Np}(\mathrm{VI})$, the cessation of the $\mathrm{Pu}(\mathrm{VI})$ oxidation at greater than $1 \mathrm{M} \mathrm{KOH}$ can be explained by the change in the mechanism of the $\mathrm{S}_{2} \mathrm{O}_{8}^{2-}$ decomposition.

Based on these observations, the optimal conditions for the preparation of $\mathrm{Pu}$ (VII) by means of persulfate are: 0.8 to $0.9 \mathrm{M} \mathrm{OH}^{-}, 0.1$ to $0.2 \mathrm{M} \mathrm{S}_{2} \mathrm{O}_{8}^{2-}$, and 80 to $90{ }^{\circ} \mathrm{C}$ temperature. Under these conditions, the yield of $\mathrm{Pu}$ (VII) with the plutonium concentration of $1 \times 10^{-3} \mathrm{M}$ is close to $100 \%$ after about 20 minutes.

3.1.3.3 Preparation of Americium(IV). It was reported that in alkaline media, pink $\mathrm{Am}(\mathrm{OH})_{3}$ can be oxidized by $\mathrm{S}_{2} \mathrm{O}_{8}^{2-}$ to an insoluble precipitate of black or dark-brown color; [probably Am(IV)] (Penneman and Asprey 1955).

The oxidation of $\mathrm{Am}(\mathrm{OH})_{3}$ by persulfate has been studied in some detail (Penneman et al. 1961). The treatment of $5 \mathrm{mg} \mathrm{Am}(\mathrm{OH})_{3}$ in $0.1 \mathrm{M} \mathrm{NaOH}$ by excess $\mathrm{K}_{2} \mathrm{~S}_{2} \mathrm{O}_{8}$ in a boiling water bath for about 2 hours gave an olive-brown precipitate. Dissolution of the precipitate by acid showed the mean oxidation number of americium was 4.53 ; i.e., in addition to Am(IV), the precipitate contained americium in higher oxidation states.

Americium(IV) has been prepared in a concentrated solution of alkali. For this purpose Am(III) was added to a hot $7 \mathrm{M}$ solution of $\mathrm{KOH}$, saturated with $\mathrm{K}_{2} \mathrm{~S}_{2} \mathrm{O}_{8}$, and the mixture held at $90^{\circ} \mathrm{C}$ for one hour. The precipitate was washed by water to remove the excess oxidizing agent. The mean oxidation number of the hydroxide was $4.0 \pm 0.1$. 


\subsubsection{Oxidation by Hypobromite}

Hypobromite, $\mathrm{BrO}^{-}$, is another oxidizing agent for transuranium elements in alkaline media. It has been used for preparation of $\mathrm{Np}(\mathrm{VII})$ and $\mathrm{Pu}(\mathrm{VII})$.

3.1.4.1 Preparation of Neptunium(VII). Neptunium(VI) in alkaline solutions is oxidized by $0.1 \mathrm{M}$ hypobromite at an appreciable rate only on heating to $70{ }^{\circ} \mathrm{C}$ (Spitsyn et al. 1968). Study of the kinetics of reaction was carried out for 1.74 to $6.5 \mathrm{M} \mathrm{NaOH}$ and $2 \times 10^{-4} \mathrm{M} \mathrm{Np}$ (VI) (Shilov et al. 1970a). In the experiments and calculations, the instability of $\mathrm{BrO}^{-}$, which is gradually decomposed with the formation of $\mathrm{Br}^{-}$and $\mathrm{BrO}_{3}^{-}$, was taken into account. Hexa- and heptavalent neptunium have no effect on the decomposition rate.

The kinetics of the $\mathrm{Np}(\mathrm{VI})$ oxidation are described by an equation for reaction of first order with respect to the metal:

$$
-d[N p(V I)] / d t=d[N p(V I I)] / d t=k[N p(V I)]
$$

The $\mathrm{k}$ value depends upon concentrations of alkali and oxidizing agent and the temperature. The treatment of experimental data gave the following empirical equation:

$$
\mathrm{k}=\mathrm{k}^{\prime}\left[\mathrm{OH}^{-}\right]^{1.6}\left[\mathrm{BrO}^{-}\right]^{0.6}
$$

Where:

$$
\mathrm{k}^{\prime}=(6.65 \pm 0.35) \times 10^{-2} \mathrm{M}^{-2.2} \min ^{-1} \text { at } 70{ }^{\circ} \mathrm{C} .
$$

The activation energy for the reaction in $6.5 \mathrm{M} \mathrm{NaOH}$ with $0.1 \mathrm{M} \mathrm{BrO}^{-}$is $87.8 \mathrm{~kJ} \mathrm{~mol}^{-1}$ (at 50.7 to $70{ }^{\circ} \mathrm{C}$ ).

The complicated dependence of the $\mathrm{Np}(\mathrm{VI})$ oxidation rate by hypobromite on the $\mathrm{NaOH}$ concentration reflects not only the participation of $\mathrm{OH}^{-}$ions in the formation of the activated complex, but also the change in the salt composition and, respectively, the ionic strength of the solution. The fractional order via $\mathrm{BrO}^{-}$can be explained by the fact that the process has several parallel pathways. Probably, in addition to the direct interaction of $\mathrm{Np}(\mathrm{VI})$ with $\mathrm{BrO}^{-}$ (in a reaction of first order relative to the oxidizing agent), the intermediate products of the $\mathrm{BrO}^{-}$decomposition contribute considerably to the kinetics of the $\mathrm{Np}$ (VII) formation in a reaction of zero order.

The oxidation of $\mathrm{Np}(\mathrm{VI})$ by hypobromite is accelerated by salts of transition metals. For example, $\mathrm{Np}$ (VII) is practically not formed in $0.5 \mathrm{M} \mathrm{NaOH}$ at $0.1 \mathrm{M} \mathrm{BrO}^{-}$and $30^{\circ} \mathrm{C}$. However, if $2.5 \times 10^{-5} \mathrm{M}$ of $\mathrm{Cu}$ (II) salt is added to this solution, $\mathrm{Np}$ (VI) is oxidized completely in about 40 minutes. A similar result is observed in the presence of (1 to 5) $\times 10^{-6} \mathrm{M}$ nickel or cobalt compounds. 
The oxidation of $\mathrm{Np}(\mathrm{VI})$ by hypobromite in solutions containing microamounts of cobalt salts occurs in a reaction of first order relative to the metal:

$$
-\mathrm{d}[\mathrm{Np}(\mathrm{VI})] / \mathrm{dt}=\mathrm{k}[\mathrm{Np}(\mathrm{VI})]
$$

The $\mathrm{k}$ value is independent of the $\mathrm{NaOH}$ concentration within the range of 0.5 to $2 \mathrm{M}$ but depends strongly on temperature, concentrations of $\mathrm{BrO}^{-}$, and catalyst (see Table 3-4). The order of reaction via hypobromite is close to 0.6 (as in the absence of catalyst). The activation energy for the reaction in the absence of catalyst decreases to $71 \mathrm{~kJ} \mathrm{~mol}^{-1}$.

Iron and silver salts (at concentrations to $5 \times 10^{-5} \mathrm{M}$ ) have no effect on the oxidation of $\mathrm{Np}(\mathrm{VI})$ by hypobromite in $0.5 \mathrm{M} \mathrm{NaOH}$ at $30^{\circ} \mathrm{C}$.

The above-mentioned data show that the optimal conditions of $\mathrm{Np}(\mathrm{VII})$ preparation by means of hypobromite are the following: 3 to $4 \mathrm{M} \mathrm{OH}^{-}, 0.05$ to $0.1 \mathrm{M} \mathrm{BrO}^{-}$and 60 to $80^{\circ} \mathrm{C}$ temperature. The oxidation can be carried out in $0.5 \mathrm{M} \mathrm{NaOH}$ at $30^{\circ} \mathrm{C}$ when $5 \times 10^{-6} \mathrm{M}$ of $\mathrm{Co}$ (II) salt is added to the solution. The $\mathrm{Np}$ (VII) solutions prepared with hypobromite are stable.

Hexavalent plutonium in $0.5 \mathrm{M}$ alkali solution is not oxidized by hypobromite (Komkov et al. 1969). Hence, under these conditions, it is possible to oxidize $\mathrm{Np}$ (VI) selectively in the presence of $\mathrm{Pu}(\mathrm{VI})$.

Table 3-4. The Influence of Experimental Conditions on the Np(VI) Oxidation Rate by Hypobromite in the Presence of $\mathrm{Co}$ (II) Salt $([\mathrm{NaOH}]=0.5 \mathrm{M})$.

\begin{tabular}{|c|c|c|c|}
\hline Temperature, ${ }^{\circ} \mathrm{C}$ & {$\left[\mathrm{BrO}^{-}\right] \times 10^{2}, \mathrm{M}$} & {$[\mathrm{Co}(\mathrm{II})] \times 10^{6}, \mathrm{M}$} & $\mathrm{k} \times 10^{2}, \min ^{-1}$ \\
\hline 30.0 & 10 & 5 & 40 \\
\hline 30.0 & 19 & 5 & 51 \\
\hline 30.0 & 5 & 5 & 32 \\
\hline 30.0 & 2.5 & 5 & 22 \\
\hline 30.0 & 10 & 1.5 & 6.9 \\
\hline 30.0 & 10 & 0.5 & 2.2 \\
\hline 40.1 & 10 & 5 & 96 \\
\hline 49.2 & 10 & 5 & 211 \\
\hline
\end{tabular}


3.1.4.2 Preparation of Plutonium(VII). Pu(VI) can be oxidized by hypobromite only in concentrated alkaline solutions. Semiquantitative data on the kinetics of this reaction were obtained for solutions $10 \mathrm{M}$ or greater in $\mathrm{KOH}$ concentrations (Komkov et al. 1969). The oxidation of $\mathrm{Pu}(\mathrm{VI})$ occurs completely and rapidly upon heating the solutions to 50 to $90{ }^{\circ} \mathrm{C}$. The decomposition of $\mathrm{BrO}^{-}$with the intense formation of oxygen bubbles proceeds as a side reaction. Because of this, precise kinetic curves of $\mathrm{Pu}$ (VII) formation were impossible to determine using spectrophotometry. The available data on $\mathrm{Pu}(\mathrm{VI})$ oxidation by hypobromite therefore are approximate, and only limited conclusions can be drawn on their basis.

The completeness and rate of the Pu(VI) oxidation increase with increasing concentrations of alkali and hypobromite. The yield of Pu(VII) is close to $100 \%$ in solutions with $0.1 \mathrm{M} \mathrm{KBrO}$ and greater than $12 \mathrm{M} \mathrm{KOH}$. The oxidation rate increases with increasing temperature from 50 to $90^{\circ} \mathrm{C}$.

The additions of $\mathrm{Fe}(\mathrm{III}), \mathrm{Ag}(\mathrm{I}), \mathrm{Cu}(\mathrm{II})$, and $\mathrm{Mn}$ (II) up to $1 \times 10^{-5} \mathrm{M}$ have practically no effect on the interaction of $\mathrm{Pu}(\mathrm{VI})$ with $\mathrm{BrO}^{-}$. Compounds of $\mathrm{Co}(\mathrm{II})$ and $\mathrm{Ni}$ (II) at the same concentrations considerably increase the reaction rate; the increase in the rate of $\mathrm{BrO}^{-}$ decomposition takes place simultaneously. Obviously, both these processes [the $\mathrm{Pu}(\mathrm{VI})$ oxidation and the $\mathrm{BrO}^{-}$decomposition] are related.

Both dilute and concentrated solutions of $\mathrm{Pu}(\mathrm{VII})$ of high stability can be prepared by means of hypobromite. The solutions are stable at room temperature over several days. However, the difficulties of handling concentrated alkaline solutions limit the use of this method for $\mathrm{Pu}$ (VII) preparation.

\subsubsection{Oxidation by Hypochlorite}

Hypochlorite was used for the oxidation of $\mathrm{Am}(\mathrm{OH})_{3}$. It was reported that the action of alkali solution containing $\mathrm{ClO}^{-}$on microgram amounts of Am(III) led to the formation of a dark precipitate (Cunningham 1949). The oxidation of $\mathrm{Am}(\mathrm{OH})_{3}$ has been studied in some detail (Penneman et al. 1961). It was found that the oxidation of Am(III) to Am(IV) proceeds only in an alkaline medium.

\subsubsection{Oxidation by Ferricyanide}

Another oxidizing agent for transuranium elements in alkaline solutions is ferricyanide, $\mathrm{Fe}(\mathrm{CN})_{6}^{3-}$. It was used for the oxidation of $\mathrm{Np}(\mathrm{VI}), \mathrm{Pu}(\mathrm{VI})$, and $\mathrm{Am}(\mathrm{III})$.

3.1.6.1 Reaction of $\mathrm{Np}$ (VI) with Ferricyanide. The oxidation of $\mathrm{Np}$ (VI) by ferricyanide is a reversible reaction; the $\mathrm{OH}^{-}$concentration has a considerable effect on the position of the equilibrium (Krot et al. 1970). Np(VI) is practically not oxidized by an equimolar amount of $\mathrm{K}_{3} \mathrm{Fe}(\mathrm{CN})_{6}$ at $\mathrm{OH}^{-}$concentrations less than $0.5 \mathrm{M}$. On the contrary, under these conditions, $\mathrm{Np}$ (VII) is reduced to $\mathrm{Np}$ (VI) completely and rapidly by $\mathrm{Fe}(\mathrm{CN})_{6}^{4}$ (ferrocyanide). 
In solutions with greater than $6 \mathrm{M} \mathrm{KOH}, \mathrm{Np}(\mathrm{VI})$ is oxidized by $\mathrm{Fe}(\mathrm{CN})_{6}^{3-}$ quantitatively. In the intermediate region, the yield of $\mathrm{Np}(\mathrm{VII})$ depends on the excess of the oxidizing agent and the experimental conditions. The equilibrium of the reaction is achieved rapidly.

$$
\mathrm{Np}(\mathrm{VI})+\mathrm{Fe}(\mathrm{CN})_{6}^{3-} \rightleftarrows \mathrm{Np}(\mathrm{VII})+\mathrm{Fe}(\mathrm{CN})_{6}^{4-}
$$

The equilibrium constant, $\mathrm{K}_{20}\left[=\left([\mathrm{Np}(\mathrm{VII})]\left[\mathrm{Fe}(\mathrm{CN})_{6}^{4}\right]\right) /\left([\mathrm{Np}(\mathrm{VI})]\left[\mathrm{Fe}(\mathrm{CN})_{6}^{3}\right]\right)\right]$, for $3.2 \mathrm{M}$ $\mathrm{KOH}$ at $23{ }^{\circ} \mathrm{C}$ is $2.0 \pm 0.2$. With the ionic strength of the solution maintained constant and equal to 4.0 by means of $\mathrm{KF}$, the logarithmic scale dependence of $\mathrm{K}_{20}$ on the $\mathrm{KOH}$ concentration is a straight line of slope 3 . At a constant concentration of $\mathrm{KOH}$, the $\mathrm{K}_{20}$ value is proportional to ionic strength, $\mu$. The total influence of $\mu$ and $\mathrm{OH}^{-}$concentration causes the $\mathrm{K}_{20}$ value to be proportional to $[\mathrm{KOH}]^{4}$.

The sharp influence of $\mathrm{OH}^{-}$concentration on the equilibrium of the reaction between $\mathrm{Np}(\mathrm{VI})$ and $\mathrm{Fe}(\mathrm{CN})_{6}^{3-}$ is due to the strong dependence of the oxidation potential of the pair $\mathrm{Np}$ (VII)/Np(VI) on the alkali concentration (see previous sections). The variation of the potential of the pair $\mathrm{Fe}(\mathrm{CN})_{6}^{3-} / \mathrm{Fe}(\mathrm{CN})_{6}^{4-}$ in solutions with different concentrations of alkali is insignificant. Under otherwise similar conditions, substituting $\mathrm{NaOH}$ for the $\mathrm{KOH}$ leads to a small decrease in the $\mathrm{K}_{20}$ value. Substituting $\mathrm{LiOH}$ results in a large decrease in the $\mathrm{Np}$ (VII) yield (see Table 3-5) (Krot et al. 1977a).

Table 3-5. The Equilibrium Constants $\mathrm{K}_{20}$ and the Rate Constants $\mathrm{k}$ for $\mathrm{Np}$ (VI) Oxidation by $\mathrm{Fe}(\mathrm{CN})_{6}^{3-}\left([\mathrm{MeOH}]=4 \mathrm{M}, 10^{\circ} \mathrm{C}\right)$.

\begin{tabular}{|c|c|c|}
\hline Alkali & $\mathrm{K}_{20}$ & $\mathrm{k} \times 10^{-2}, \mathrm{M}^{-1} \min ^{-1}$ \\
\hline $\mathrm{KOH}$ & 3.1 & 5.7 \\
\hline $\mathrm{NaOH}$ & 2.7 & 3.8 \\
\hline $\mathrm{LiOH}$ & 0.7 & 2.9 \\
\hline
\end{tabular}

At room temperature, the oxidation of $\mathrm{Np}$ (VI) by ferricyanide occurs rapidly. However, at $10^{\circ} \mathrm{C}$ and with concentrations of reagents of about $10^{-4} \mathrm{M}$, the reaction is decelerated and its rate is measured by simple methods. Study has shown that $\mathrm{Np}(\mathrm{VI})$ oxidation by $\mathrm{Fe}(\mathrm{CN})_{6}^{3-}$ ions is described by an equation for a bimolecular reaction (Krot et al. 1977b):

$$
-\mathrm{d}[\mathrm{Np}(\mathrm{VI})] / \mathrm{dt}=\mathrm{k}_{20}[\mathrm{~Np}(\mathrm{VI})]\left[\mathrm{Fe}(\mathrm{CN})_{6}^{3-}\right]
$$

The rate constant $\mathrm{k}_{20}$ in $\mathrm{KOH}$ solutions changes slightly within the ionic strength range of 1.5 to 3.0 (using $\mathrm{KNO}_{3}$ ) but depends considerably on $\mathrm{OH}^{-}$concentration (see Table 3-6). It is possible to consider, as a first approximation, that the $\mathrm{k}_{20}$ value is proportional to $\mathrm{OH}^{-}$ concentration. From here it follows that the $\mathrm{Np}(\mathrm{VII})$ reduction rate by $\mathrm{Fe}(\mathrm{CN})_{6}^{+}$decreases in 
proportion to $\left[\mathrm{OH}^{-}\right]^{2}$, because $\mathrm{K}_{20}$ is a function of $\left[\mathrm{OH}^{-}\right]^{3}$. At an ionic strength, $\mu$, of $3.0 \mathrm{M}$ and $10{ }^{\circ} \mathrm{C}$, the values of $\mathrm{K}_{20}$ and $\mathrm{k}_{20}$ in $2.5 \mathrm{M} \mathrm{KOH}$ are equal to 0.55 and $3.15 \times 10^{2} \mathrm{M}^{-1} \mathrm{~min}^{-1}$, respectively. Under these conditions, the rate constant of reaction between $\mathrm{Np}(\mathrm{VII})$ and $\mathrm{Fe}(\mathrm{CN})_{6}^{4-}$ is $\mathrm{k}_{-20}=\mathrm{k}_{20} / \mathrm{K}_{20}=5.7 \times 10^{2} \mathrm{M}^{-1} \mathrm{~min}^{-1}$.

Table 3-6. Rate Constants for $\mathrm{Np}(\mathrm{VI})$ Oxidation by $\mathrm{Fe}(\mathrm{CN})_{6}^{3-}$ in $\mathrm{KOH}$ Solutions $\left([\mathrm{Np}(\mathrm{VI})]_{\mathrm{o}}=1.26 \times 10^{-4} \mathrm{M}, 10^{\circ} \mathrm{C}\right)$.

\begin{tabular}{|c|c|c|}
\hline$[\mathrm{KOH}], \mathbf{M}$ & $\mu, \mathbf{M}$ & $\mathbf{k}_{20}, \mathbf{M}^{-1} \mathrm{~min}^{-1}$ \\
\hline 4.0 & 4.0 & 570 \\
\hline 3.5 & 3.5 & 460 \\
\hline 3.0 & 3.0 & 400 \\
\hline 2.5 & 3.0 & 315 \\
\hline 2.0 & 3.0 & 265 \\
\hline 1.5 & 3.0 & 215 \\
\hline 1.5 & 2.8 & 210 \\
\hline 1.5 & 2.8 & 195 \\
\hline 1.5 & 2.0 & 185 \\
\hline
\end{tabular}

The rate of $\mathrm{Np}(\mathrm{VI})$ oxidation by $\mathrm{Fe}(\mathrm{CN})_{6}^{3-}$ ions is somewhat decelerated upon the transition from $\mathrm{KOH}$ to $\mathrm{NaOH}$ and $\mathrm{LiOH}$ (see Table 3-5).

The activation energy of the reaction in $3 \mathrm{M} \mathrm{KOH}$ is $40.1 \mathrm{~kJ} \mathrm{~mol}^{-1}$. The low value of the activation energy of the $\mathrm{Np}(\mathrm{VI})$ reduction is because $\mathrm{K}_{20}$ depends only slightly on temperature change.

3.1.6.2 Preparation of Plutonium(VII). The interaction of $\mathrm{Pu}(\mathrm{VI})$ with $\mathrm{Fe}(\mathrm{CN})_{6}^{3-}$ becomes noticeable in solutions with greater than $8 \mathrm{M} \mathrm{KOH}$ (Krot et al. 1977a). The oxidation of $5 \times 10^{-4} \mathrm{M} \mathrm{Pu}(\mathrm{VI})$ in $12 \mathrm{M} \mathrm{KOH}$ and $2 \times 10^{-3} \mathrm{M} \mathrm{Fe}(\mathrm{CN})_{6}^{3-}$ proceeds virtually to completion. Under these conditions the reaction has a high rate even in the cold. However, prepared solutions of $\mathrm{Pu}(\mathrm{VII})$ are unstable upon standing; their characteristic color disappears in about 2 hours. Most likely, Pu(VII) is reduced gradually by cyanide ions formed from the decomposition of the iron cyanide complex.

3.1.6.3 Oxidation of Americium(III). Am(III) in alkaline solutions is oxidized by ferricyanide to $\mathrm{AmO}_{2}^{+}$. The soluble complex, $\left(\mathrm{AmO}_{2}\right)_{3} \mathrm{Fe}(\mathrm{CN})_{6}$, is formed as a result of the reaction. The complex is decomposed gradually with the release of the precipitate $\mathrm{Na}_{2} \mathrm{AmO}_{2}(\mathrm{OH})_{3} \cdot \mathrm{xH}_{2} \mathrm{O}$. Americium(IV) hydroxide appears if equal amounts of Am(III) and $\mathrm{K}_{3} \mathrm{Fe}(\mathrm{CN})_{6}$ are combined (Kulyako et al. 1993). 


\subsubsection{Oxidation by Xenon Compounds}

Some xenon compounds (for instance, $\mathrm{Na}_{4} \mathrm{XeO}_{6}, \mathrm{XeO}_{3}$, and $\mathrm{XeF}_{2}$ ) are oxidizing agents for transuranium elements. In this section the use of these compounds for actinide oxidation in alkaline media is described.

3.1.7.1 The Use of $\mathrm{Na}_{4} \mathrm{XeO}_{6} . \mathrm{Np}(\mathrm{VI})$ in alkaline solutions is oxidized by $\mathrm{XeO}_{6}^{4}$ (perxenate) upon heating. The half-time for the oxidation of $2 \times 10^{-4} \mathrm{M} \mathrm{Np}(\mathrm{VI})$ in $1 \mathrm{M} \mathrm{KOH}$, using $1 \times 10^{-3} \mathrm{M} \mathrm{Xe}$ (VIII) and at $70^{\circ} \mathrm{C}$, is $15 \mathrm{~min}$ (Spitsyn et al. 1968). The reaction rate increases somewhat with decrease in the $\mathrm{KOH}$ concentration. The addition of perxenate to slightly-acid or neutral solutions of $\mathrm{Np}$ (VI) does not lead to the formation of $\mathrm{Np}$ (VII).

$\mathrm{Pu}(\mathrm{VI})$ in 0 to $12 \mathrm{M} \mathrm{NaOH}$ solution does not react with perxenate (Komkov et al. 1968). To some extent, the low rate is due to the low solubility of $\mathrm{Na}_{4} \mathrm{XeO}_{6}$ in concentrated $\mathrm{NaOH}$ solution. $\mathrm{Pu}(\mathrm{VI})$ is partially oxidized by $\mathrm{Xe}$ (VIII) in hot concentrated solutions of $\mathrm{KOH}$, but the yield of $\mathrm{Pu}(\mathrm{VII})$ is small. Only $25 \%$ of the $\mathrm{Pu}(\mathrm{VI})$ was converted to $\mathrm{Pu}(\mathrm{VII})$ during $15 \mathrm{~min}$ in $11 \mathrm{M} \mathrm{KOH}, 0.02 \mathrm{M} \mathrm{XeO}_{6}^{4}$, and $95^{\circ} \mathrm{C}$. Further heating did not increase the $\mathrm{Pu}$ (VII) yield.

3.1.7.2 The Use of $\mathrm{XeO}_{3}$. Xenon trioxide $\left(\mathrm{XeO}_{3}\right)$ reacts with $\mathrm{Np}(\mathrm{VI})$ in alkaline solutions more rapidly than perxenate ion (Spitsyn et al. 1968). The addition of $5 \times 10^{-3} \mathrm{M} \mathrm{XeO}_{3}$ to $\mathrm{Np}$ (VI) solution in $1 \mathrm{M} \mathrm{KOH}$ gives rise to the gradual appearance of the characteristic green color of $\mathrm{Np}(\mathrm{VII})$ even in cold solutions. The duration of reaction is more than 3 hours. The oxidation rate increases sharply upon heating. At $1 \mathrm{M} \mathrm{NaOH}, 2.5 \times 10^{-3} \mathrm{M} \mathrm{XeO}_{3}$, and $50{ }^{\circ} \mathrm{C}$, the time for the oxidation of $2 \times 10^{-4} \mathrm{M} \mathrm{Np}(\mathrm{VI})$ to $50 \%$ is about $3 \mathrm{~min}$; at $70^{\circ} \mathrm{C}$ it is 4.5 times faster. Decrease in the alkali concentration to $0.25 \mathrm{M}$ leads to some deceleration of the reaction. Increase in the $\mathrm{KOH}$ concentration accelerates the $\mathrm{Np}(\mathrm{VI})$ oxidation. The reaction proceeds to completion in about $35 \mathrm{~min}$ at 10 to $11 \mathrm{M} \mathrm{KOH}, 2.1 \times 10^{-3} \mathrm{M} \mathrm{XeO}_{3}$, $2.1 \times 10^{-4} \mathrm{M} \mathrm{Np}(\mathrm{VI})$, and $20^{\circ} \mathrm{C}$ (Klimov et al. 1971). If the concentrations of the reacting components are the same and equal to $2 \times 10^{-3} \mathrm{M}$ under the above-mentioned conditions, the half-time of the $\mathrm{Np}(\mathrm{VI})$ oxidation is about 30 minutes.

The interaction of $\mathrm{Np}(\mathrm{VI})$ with $\mathrm{XeO}_{3}$ in alkaline solutions is accompanied by an oxidant decomposition side reaction, forming perxenate, which can also participate in the $\mathrm{Np}(\mathrm{VI})$ oxidation.

The Use of $\mathrm{XeF}_{2}$. Xenon $\left(\mathrm{XeF}_{2}\right)$ difluoride is suitable for $\mathrm{Np}(\mathrm{VI})$ oxidation only in solutions with moderate concentrations of alkali (Klimov et al. 1971, Gusev et al. 1972). Aqueous solutions of $\mathrm{XeF}_{2}$ are somewhat more effective. They can be used for $\mathrm{Np}$ (VI) oxidation in alkali concentrations up to $5 \mathrm{M}$ (Zielen and Cohen 1970). The reaction proceeds rapidly.

A 200-fold excess of $\mathrm{XeF}_{2}$ is required for the quantitative oxidation of $\mathrm{Np}$ (VI) in 0.2 to $1.0 \mathrm{M} \mathrm{NaOH}$ or $\mathrm{KOH}$ (Gusev et al. 1972). Addition of 5 to $200 \mathrm{mg} \mathrm{XeF} 2$ to $20 \mathrm{~mL}$ of $2 \mathrm{M} \mathrm{NaOH}$ with $2 \times 10^{-4} \mathrm{M} \mathrm{Np}$ (VII) prepared by ozonation leads to a decrease in $\mathrm{Np}$ (VII) concentration by 3 to $12 \%$; i.e. reduction occurs. 
In the presence of $10^{-5} \mathrm{M} \mathrm{Cu}(\mathrm{II})$ salt, $\mathrm{Np}(\mathrm{VI})$ oxidation by $\mathrm{XeF}_{2}$ in $0.5 \mathrm{M} \mathrm{NaOH}$ is not observed. Under the same conditions, microamounts of cobalt and nickel have no effect on $\mathrm{Np}(\mathrm{VI})$ oxidation.

Only a short-lived coloration characteristic of $\mathrm{Pu}(\mathrm{VII})$ solutions appears upon the action of 200-fold excess of $\mathrm{XeF}_{2}$ on $\mathrm{Pu}(\mathrm{VI})$ in 0.2 to $1.2 \mathrm{M} \mathrm{NaOH}$. The color disappears in about 10 minutes. The yield of $\mathrm{Pu}$ (VII) 3 minutes after the addition of $\mathrm{XeF}_{2}$ is not more than $10 \%$. The Pu(VI) oxidation is not observed at greater than $2 \mathrm{M} \mathrm{OH}^{-}$. The rapid discoloration of $\mathrm{Pu}(\mathrm{VII})$ solutions prepared by ozonation in 0.5 to $3 \mathrm{M} \mathrm{KOH}$ or $\mathrm{NaOH}$ proceeds upon the addition of $\mathrm{XeF}_{2}$; the optical absorption spectrum of the formed solution is identical with the spectrum of Pu(VI) solution.

\subsubsection{Oxidation by Silver Oxides}

Silver oxides, $\mathrm{Ag}_{2} \mathrm{O}$ and $\mathrm{AgO}$, are also suitable for some oxidation reactions of transuranium elements in alkaline solutions.

3.1.8.1 Preparation of $\mathrm{Np}(\mathrm{VII})$. Both $\mathrm{Ag}_{2} \mathrm{O}$ and $\mathrm{AgO}$ are usable for the preparation of $\mathrm{Np}$ (VII) in alkaline solutions (Krot et al. 1970). $\mathrm{Np}$ (VI) oxidation by $\mathrm{Ag}_{2} \mathrm{O}$ occurs to a noticeable extent only in solutions with greater than $8 \mathrm{M} \mathrm{OH}^{-}$. The reaction rate at room temperature is low; it is necessary to perform the process at temperatures more than $50{ }^{\circ} \mathrm{C}$. In solutions heated to $60^{\circ} \mathrm{C}$, the reaction is finished in 15 to 20 minutes.

The fraction of $\mathrm{Np}(\mathrm{VI})$ oxidized depends upon the concentrations of alkali and oxidizing agent. The $\mathrm{Np}$ (VII) yield in $5 \times 10^{-4} \mathrm{M} \mathrm{Np}(\mathrm{VI})$ and $9 \mathrm{M} \mathrm{NaOH}$ at $60^{\circ} \mathrm{C}$ using freshly-prepared $\mathrm{Ag}_{2} \mathrm{O}(10 \mathrm{mg} \mathrm{cm}$ ) is 10 to $15 \%$. If the concentration of alkali is $12 \mathrm{M}$ and the other conditions are the same, the Np(VII) yield reaches 70 to $80 \%$. Decrease in the concentration of oxidizing agent from 10 to $2 \mathrm{mg} \mathrm{cm}^{-3}$ (under otherwise similar conditions) leads to a two-fold decrease in the yield. The $\mathrm{Np}$ (VII) yield increases slightly by increasing temperature to $90^{\circ} \mathrm{C}$.

AgO oxidizes $\mathrm{Np}(\mathrm{VI})$ even in $0.1 \mathrm{M} \mathrm{KOH}$. The reaction rate is high even at room temperature. In solutions heated to $59^{\circ} \mathrm{C}$, equilibrium is achieved in 3 to 5 minutes (with intense stirring). Data from Table 3-7 illustrate the influences of alkali and oxidizing agent concentrations.

From the data, it is seen that in 2 to $3 \mathrm{M} \mathrm{KOH}, \mathrm{AgO}$ in excess can oxidize $\mathrm{Np}(\mathrm{VI})$ to $\mathrm{Np}$ (VII) almost quantitatively.

3.1.8.2 Preparation of Plutonium(VII). Extensive oxidation of Pu(VI) by AgO takes place only with greater than $8 \mathrm{M} \mathrm{OH}^{-}$(Peretrukhin et al. 1971). The Pu(VII) yield in $10 \mathrm{M} \mathrm{NaOH}$ is close to $100 \%$. The reaction rate in cold solutions is small. The rate increases rapidly with increasing temperature. At 80 to $90^{\circ} \mathrm{C}$, the $\mathrm{Pu}(\mathrm{VI})$ oxidation is complete in less than 15 minutes. 
Table 3-7. The Effect of $\mathrm{KOH}$ and AgO Concentrations on the Np(VII) Yield at $[\mathrm{Np}(\mathrm{VI})]_{\mathrm{o}}=1.3 \times 10^{-4} \mathrm{M}$ and $50{ }^{\circ} \mathrm{C}$.

\begin{tabular}{|c|c|c|}
\hline$[\mathrm{KOH}], \mathrm{M}$ & {$\left[\mathrm{AgO}, \mathrm{mg} \mathrm{cm}^{-3}\right.$} & $\mathrm{Np}(\mathrm{VII})$ yield, \% \\
\hline 0.18 & 2.0 & 54.0 \\
\hline 0.32 & 2.0 & 60.8 \\
\hline 0.68 & 2.0 & 72.0 \\
\hline 1.27 & 2.0 & 88.7 \\
\hline 2.48 & 2.0 & 92.6 \\
\hline 3.36 & 2.0 & 98.5 \\
\hline 1.27 & 0.4 & 72.7 \\
\hline 1.27 & 0.8 & 79.0 \\
\hline 1.27 & 2.0 & 88.7 \\
\hline 1.27 & 4.0 & 92.7 \\
\hline
\end{tabular}

\subsubsection{Oxidation by Permanganate}

The interaction of $\mathrm{Np}(\mathrm{VI})$ and $\mathrm{Pu}(\mathrm{VI})$ with $\mathrm{KMnO}_{4}$ alkaline solutions occurs via reversible reactions (Peretrukhin et al. 1971; Shilov et al. 1970b):

$$
\begin{aligned}
& \mathrm{Np}(\mathrm{VI})+\mathrm{MnO}_{4}^{-} \rightleftarrows \mathrm{Np}(\mathrm{VII})+\mathrm{MnO}_{4}^{2-} \\
& \mathrm{Pu}(\mathrm{VI})+\mathrm{MnO}_{4}^{-} \rightleftarrows \mathrm{Pu}(\mathrm{VII})+\mathrm{MnO}_{4}^{2-}
\end{aligned}
$$

The equilibria are established rapidly at 20 to $25^{\circ} \mathrm{C}$ and strongly depend on the alkali concentration. $\mathrm{Np}(\mathrm{VI})$ is oxidized in 3 to $4 \mathrm{M} \mathrm{NaOH}$. However, under these conditions, besides the preparation of $\mathrm{Np}(\mathrm{VII})$, there is the gradual decomposition of the excess $\mathrm{MnO}_{4}^{-}$ and the additional formation of $\mathrm{MnO}_{4}^{2-}$. The rate of the last process depends on the presence of microamounts of catalysts and impurities. It is difficult to exclude this process completely (even using highly-purified reagents) since the potential of the pair $\mathrm{MnO}_{4} / \mathrm{MnO}_{4}^{2-}$ is higher than the potential of $\mathrm{O}_{2}$ production from alkaline aqueous solutions.

The potential of the pair $\mathrm{Np}(\mathrm{VII}) / \mathrm{Np}$ (VI) sharply increases with decreasing alkali concentration, whereas the potential of the pair $\mathrm{Mn}(\mathrm{VII}) / \mathrm{Mn}(\mathrm{VI})$ changes slightly. As a result, in solutions with $\mathrm{pH} 10$ to $11, \mathrm{~Np}$ (VII) rapidly oxidizes $\mathrm{MnO}_{4}^{2-}$ to $\mathrm{MnO}_{4}^{-}$. 
$\mathrm{Pu}(\mathrm{VI})$ is oxidized by $\mathrm{KMnO}_{4}$ only in solutions with 10 to $14 \mathrm{M} \mathrm{NaOH}$ (Peretrukhin et al. 1971). The process is accompanied by the reduction of the excess $\mathrm{MnO}_{4}^{-}$by water to form $\mathrm{MnO}_{4}^{2-}$. This side reaction complicates the observation of reaction between $\mathrm{Pu}(\mathrm{VI})$ and $\mathrm{MnO}_{4}^{-}$. Upon the dilution of the solution to 2 to $4 \mathrm{M} \mathrm{NaOH}$, the fast reverse oxidation of $\mathrm{MnO}_{4}^{2-}$ by $\mathrm{Pu}(\mathrm{VII})$ is observed and the red-violet $\mathrm{MnO}_{4}^{-}$is formed.

It was shown that $\mathrm{MnO}_{4}^{-}$oxidizes $\mathrm{Am}$ (III) to $\mathrm{Am}(\mathrm{IV})$ in alkaline media (Penneman et al. 1961).

\subsubsection{Other Oxidation Processes}

Other oxidizing agents for transuranium elements in alkaline media are the $\mathrm{Cu}(\mathrm{III})$ periodate complex, periodate, bismuthate, other oxidized transuranium elements, hydrogen peroxide, and oxygen.

3.1.10.1 Periodate Complex of $\mathrm{Cu}(\mathrm{III})$. Excess $\mathrm{Cu}(\mathrm{III})$ complexed with periodate rapidly oxidizes $\mathrm{Np}(\mathrm{VI})$ and $\mathrm{Pu}(\mathrm{VI})$ at $\mathrm{NaOH}$ concentrations higher than 1 and $11 \mathrm{M}$, respectively (Shatokhina et al. 1977).

3.1.10.2 Periodate and Bismuthate. $N p(V I)$ is oxidized by periodate only in hot alkaline solutions (Spitsyn et al. 1968). The time of $50 \%$ oxidation of $2 \times 10^{-4} \mathrm{M} \mathrm{Np}(\mathrm{VI})$ at $\mathrm{NaOH}$ and periodate concentrations of 1 and $0.1 \mathrm{M}$, respectively, at $85^{\circ} \mathrm{C}$ is 20 minutes. Increase in the alkali concentration causes an increase in the reaction rate; in $5 \mathrm{M} \mathrm{KOH}$ (under otherwise similar conditions), oxidation is complete in about 10 minutes.

$\mathrm{Pu}(\mathrm{VI})$ is not oxidized by periodate either in dilute or concentrated alkali solutions (Komkov et al. 1968).

$\mathrm{Np}$ (VI) oxidation by sodium bismuthate in dilute alkaline solution is a heterogeneous reaction occurring rapidly only at boiling temperatures (Spitsyn et al. 1968). Green solutions with an optical absorption spectrum characteristic of $\mathrm{Np}(\mathrm{VII})$ are formed at completion and are observed upon removal of the excess oxidant by centrifugation.

3.1.10.3 Plutonium(VII) and Plutonium(VI). Plutonium(VII) is a stronger oxidant than $\mathrm{Np}$ (VII). Hence, the reaction

$$
\mathrm{Np}(\mathrm{VI})+\mathrm{Pu}(\mathrm{VII}) \rightarrow \mathrm{Np}(\mathrm{VII})+\mathrm{Pu}(\mathrm{VI})
$$

is possible. Experiments have shown that this reaction is fast at room temperature (Shilov et al. 1970b). It is irreversible at any alkali concentration because the dependencies of the oxidation potentials of the pairs $\mathrm{Pu}(\mathrm{VII}) / \mathrm{Pu}(\mathrm{VI})$ and $\mathrm{Np}(\mathrm{VII}) / \mathrm{Np}(\mathrm{VI})$ on $\mathrm{OH}^{-}$ concentration are symbate. 
$\mathrm{Np}(\mathrm{VI})$ in alkaline solutions can be oxidized not only by $\mathrm{Pu}(\mathrm{VII})$ but also $\mathrm{Pu}(\mathrm{VI})$ (Shilov 1976). The reaction

$$
\mathrm{Np}(\mathrm{VI})+\mathrm{Pu}(\mathrm{VI}) \rightleftarrows \mathrm{Np}(\mathrm{VII})+\mathrm{Pu}(\mathrm{V})
$$

is reversible and occurs with high rate. Because of the rapid equilibration, it is concluded that the hepta-, hexa- and pentavalent ions in concentrated alkali solution have similar structures; i.e., the charge transfer occurs without appreciable reconstruction. The equilibrium depends upon the concentration of alkali. The equilibrium constant, $\mathrm{K}_{25}$, is $[\mathrm{Np}(\mathrm{VII})][\mathrm{Pu}(\mathrm{V})] /\left([\mathrm{Np}(\mathrm{VI})][\mathrm{Pu}(\mathrm{VI})]\right.$; in $7.8 \mathrm{M} \mathrm{NaOH}$ at $24{ }^{\circ} \mathrm{C}, \mathrm{K}_{25}$ is $1.8 \times 10^{-2}$. The $\mathrm{K}_{25}$ value becomes 0.14 by increasing the $\mathrm{NaOH}$ concentration to $10.1 \mathrm{M}$.

It has been shown (Bourges 1972) that $\mathrm{Pu}(\mathrm{V})$ is formed on the addition of an equimolar amount of $\mathrm{Pu}(\mathrm{VI})$ to $\mathrm{Pu}(\mathrm{IV})$ hydroxide in $4 \mathrm{M} \mathrm{NaOH}$.

3.1.10.4 Americium(VI). The rapid formation of $\mathrm{Np}(\mathrm{VII})$ is observed upon the addition of a bicarbonate or slightly-acid solution of $A m(V I)$ to $\mathrm{Np}(\mathrm{VI})$ solution in $1 \mathrm{M} \mathrm{NaOH}$ (Nikolaevsky et al. 1974):

$$
\mathrm{Np}(\mathrm{VI})+\mathrm{Am}(\mathrm{VI}) \rightleftarrows \mathrm{Np}(\mathrm{VII})+\mathrm{Am}(\mathrm{V})
$$

$A m(V)$ does not react with $\mathrm{Np}(\mathrm{VI})$ in alkaline solutions. The equilibrium of reaction (26) depends upon the $\mathrm{OH}^{-}$concentration. The $\mathrm{Np}(\mathrm{VI})$ oxidation begins at $0.016 \mathrm{M} \mathrm{OH}^{-}$. The yield of $\mathrm{Np}$ (VII) increases with increasing alkali concentration and reaches about $100 \%$ in 3 to $4 \mathrm{M} \mathrm{NaOH}$.

The addition of $\mathrm{Am}(\mathrm{VI})$ to $\mathrm{Pu}(\mathrm{VI})$ solution in $1 \mathrm{M} \mathrm{NaOH}$ does not lead to the formation of $\mathrm{Pu}(\mathrm{VII})$. The equilibrium of the reaction:

$$
\mathrm{Pu}(\mathrm{VI})+\mathrm{Am}(\mathrm{VI}) \rightleftarrows \mathrm{Pu}(\mathrm{VII})+\mathrm{Am}(\mathrm{V})
$$

is shifted to the right only at $\mathrm{OH}^{-}$concentrations greater than $7.5 \mathrm{M}$ (Nikolaevsky et al. 1974). The equilibrium is established instantaneously on mixing the reagents.

3.1.10.5 Hydrogen Peroxide. The oxidation of $\mathrm{Am}(\mathrm{OH})_{3}$ to $\mathrm{Am}(\mathrm{IV})$ by $\mathrm{H}_{2} \mathrm{O}_{2}$ was noted (Penneman and Asprey 1955) and later studied in some detail (Buijs and Louwrier 1966). In the more recent study, an acid Am(III) solution, containing $\mathrm{H}_{2} \mathrm{O}_{2}$, was neutralized by a concentrated ammonia solution. The formed precipitate (probably, Am(III) hydroperoxide) was treated with concentrated solutions of ammonia or $\mathrm{KOH}$. Am(IV) hydroxide product was prepared. Formation of Am(IV) was accelerated by heating to $90^{\circ} \mathrm{C}$. 
3.1.10.6 Oxygen. The behavior of $\mathrm{Pu}(\mathrm{IV})$ and $\mathrm{Pu}(\mathrm{VI})$ in 1 to $15 \mathrm{M} \mathrm{NaOH}$ over extended time periods was studied (Delegard 1987). It was found that $\mathrm{Pu}(\mathrm{V})$ accumulated in the solution over the precipitate. The question of possible oxidants was not considered (Delegard 1987). We believe that such oxidants may be oxygen, products of water $\alpha$-radiolysis, and $\mathrm{NO}_{2}^{-}$formed on radiolytic reduction of $\mathrm{NO}_{3}^{-}$.

\subsection{REDUCTION REACTIONS}

The reduction reactions can be divided conditionally into two groups: the first group includes the fast reactions studied by pulse methods, the second group consists of the reactions occurring with moderate rate, especially in solutions with high alkali concentration. The kinetics of some fast reactions are discussed in Section 5.0.

Reagents which rapidly reduce hepta- and hexavalent actinides are the hydrated electron ( $\mathrm{e}_{\mathrm{aq}}^{-}$), the hydrogen atom, $\mathrm{HO}_{2}, \mathrm{O}_{2}^{-}, \mathrm{H}_{2} \mathrm{O}_{2}$, ascorbic acid, hydrazine, hydroxylamine, $\mathrm{Sn}(\mathrm{II}), \mathrm{Np}(\mathrm{V})$, and $\mathrm{Pu}(\mathrm{V})$. Heptavalent actinides in diluted alkali solutions react rapidly with $\mathrm{Fe}(\mathrm{CN})_{6}^{4}$. $\mathrm{Np}(\mathrm{VI})$ rapidly reduces $\mathrm{Pu}(\mathrm{VII}), \mathrm{Am}(\mathrm{VII})$ and $\mathrm{Am}(\mathrm{VI})$. Pu(VI) interacts rapidly with Am(VII).

The second group includes the reactions of heptavalent and some hexavalent actinides with reducing agents such as formaldehyde, methanol, ethanol, sulfite, iodide, oxalate, thiosulfate, formate, ethylenediaminetetraacetate (EDTA), and citrate as well as many other organic compounds used as extractants (for example, tertiary amines and quaternary ammonium bases). Pu(VII) reacts with moderate rate with iodate and water (Krot et al. 1977a; Shilov and Krot 1969; Komkov et al. 1970).

\subsubsection{Reduction of $\mathrm{Np}(\mathrm{VII})$}

Table 3-8 shows some data on the rate of $\mathrm{Np}$ (VII) reactions with compounds often used as reducing agents (Shilov and Krot 1969). In cold $\mathrm{Np}$ (VII) does not react to a noticeable extent with ethanol, nitrite, oxalate, and acetate both in 0.1 and $2 \mathrm{M}$ alkali solutions. Increase in temperature to $65^{\circ} \mathrm{C}$ leads to a decrease in $\mathrm{Np}$ (VII) stability with respect to ethanol and oxalate, especially at low $\mathrm{OH}^{-}$concentration.

Formaldehyde is a particularly effective reducing agent which reduces $\mathrm{Np}$ (VII) in cold $0.1 \mathrm{M}$ alkali solution. Citrate, formate, thiosulfate, and EDTA are weaker reducing agents than formaldehyde.

\subsubsection{Kinetics of Pu(VI) Reduction by Water}

Plutonium(VII) in alkaline solutions is reduced by water to $\mathrm{Pu}(\mathrm{VI})$, especially in solutions with low $\mathrm{OH}^{-}$concentration. The kinetics of this process depends primarily on the purity of 
the solutions and the alkali concentration (Komkov and Krot 1970). It was shown that the reduction of $\mathrm{Pu}(\mathrm{VII})$ within the range of concentrations of (1.6 to 2.5$) \times 10^{4} \mathrm{M}$ in 0.044 to $0.1 \mathrm{M} \mathrm{KOH}$ solutions is proportional to the metal concentration to the 1.2 to 1.3 power. The time of reduction to $50 \%$ at $25{ }^{\circ} \mathrm{C}$ and $1 \mathrm{M}$ ionic strength $(\mu)$ is $18.3,21,26.2$, and $29.8 \mathrm{~min}$ for $\mathrm{KOH}$ solutions with concentrations of $44,53,60$, and $67.5 \mathrm{mM}$, respectively.

- Hence, the reduction rate decreases with increasing alkali concentration (i.e., the rate constant is inversely proportional to $\mathrm{OH}^{-}$concentration). The activation energy of the reduction reaction at 25 to $45^{\circ} \mathrm{C}$ is $60.5 \mathrm{~kJ} \mathrm{~mol}^{-1}(\mu=1.0$ and $0.1 \mathrm{M} \mathrm{KOH})$. The authors suggest that the step controlling the rate is the abstraction of $\mathrm{OH}$ from the hydrolyzed $\mathrm{Pu}$ (VII) anion (Komkov and Krot 1970). The $\mathrm{OH}$ then is converted to $\mathrm{O}^{-}$. The combination of $\mathrm{O}^{-}$with $\mathrm{OH}$ gives $\mathrm{HO}_{2}^{-}$which rapidly reduces two $\mathrm{Pu}(\mathrm{VII})$ ions.

Table 3-8. Time, in Minutes, for $50 \%$ Reduction of $2.5 \times 10^{-4} \mathrm{M} \mathrm{Np}$ (VII) with Different Compounds.

\begin{tabular}{|c|c|c|c|c|c|}
\hline \multirow{2}{*}{$\begin{array}{c}\text { Reducing } \\
\text { agent }\end{array}$} & \multirow{2}{*}{ Concentration, $\mathrm{M}$} & \multicolumn{2}{|c|}{$0.1 \mathrm{M} \mathrm{NaOH}^{\mathrm{a}}$} & \multicolumn{2}{c|}{$2 \mathrm{M} \mathrm{NaOH}^{\mathrm{b}}$} \\
\cline { 3 - 6 } & $25{ }^{\circ} \mathrm{C}$ & $65^{\circ} \mathrm{C}$ & $25{ }^{\circ} \mathrm{C}$ & $65{ }^{\circ} \mathrm{C}$ \\
\hline $\mathrm{NH}_{3}$ & 0.3 & $>100$ & $>100$ & - & - \\
\hline $\mathrm{NO}_{2}^{-}$ & 0.07 & $>100$ & $>100$ & $>100$ & $>100$ \\
\hline $\mathrm{CH}_{3} \mathrm{COO}^{-}$ & 0.20 & $>100$ & $>100$ & $>100$ & $>100$ \\
\hline $\mathrm{C}_{2} \mathrm{O}_{4}^{2-}$ & 0.07 & $>100$ & 32 & $>100$ & $>100$ \\
\hline $\mathrm{EDTA}$ & 0.01 & 75 & 1.1 & $>100$ & 45 \\
\hline $\mathrm{C}_{6} \mathrm{H}_{5} \mathrm{O}_{7}^{3}$ & 0.09 & 12 & 0.4 & - & 22 \\
\hline $\mathrm{HCOO}^{-}$ & 0.09 & 50 & 2.5 & $>100$ & 20 \\
\hline $\mathrm{S}_{2} \mathrm{O}_{3}^{2-}$ & 0.05 & 65 & - & $>100$ & 65 \\
\hline $\mathrm{C}_{2} \mathrm{H}_{5} \mathrm{OH}$ & 1.50 & $>100$ & 5 & $>100$ & 30 \\
\hline $\mathrm{CH}_{2} \mathrm{O}$ & 0.06 & 1.5 & 0.1 & - & 0.3 \\
\hline
\end{tabular}

${ }^{2}$ At ionic strength 0.5

${ }^{b}$ At ionic strength of about 2

The reduction of (1.0 to 1.7$) \times 10^{-3} \mathrm{M} \mathrm{Pu}$ (VII) in 0.3 to $1.96 \mathrm{M} \mathrm{NaOH}$ was studied (Bhattacharyya et al. 1982). The reduction rate is described by the equation

$$
-\mathrm{d}[\mathrm{Pu}(\mathrm{VII})] / \mathrm{dt}=\mathrm{k}[\mathrm{Pu}(\mathrm{VII})]
$$


up to 75 to $95 \%$ completion of the reaction. The apparent rate constant is proportional to $\left[\mathrm{OH}^{-}\right]^{-\mathrm{n}}$; $\mathrm{n}$ equals 1 at $\mathrm{OH}^{-}$concentrations of greater than $1 \mathrm{M}$ and $\mathrm{n}$ equals 2 when $\mathrm{OH}^{-}$ concentrations lie between 0.3 and $0.62 \mathrm{M}$. In $0.3 \mathrm{M} \mathrm{NaOH}$ solution, the rate constant for reduction of $1 \times 10^{-3} \mathrm{M} \mathrm{Pu}$ (VII) does not depend on ionic strength within the range of 0.5 to $2 \mathrm{M}$; at ionic strength 0.5 , the rate constant decreases by $25 \%$ when the solution contains $2 \times 10^{-3}$ or $5 \times 10^{-2} \mathrm{M} \mathrm{CO}_{3}^{2}$.

Activation energies for $1.7 \times 10^{-3} \mathrm{M} \mathrm{Pu}$ (VII) are $121 \mathrm{~kJ} \mathrm{~mol}^{-1}$ for $1 \mathrm{M} \mathrm{NaOH}$ and $1 \mathrm{M}$ $\mathrm{NaClO}_{4}$ solution at 28.4 to $38.2{ }^{\circ} \mathrm{C}$; and $33.4 \mathrm{~kJ} \mathrm{~mol}^{-1}$ for $0.5 \mathrm{M} \mathrm{NaOH}$ and $1.5 \mathrm{M} \mathrm{NaClO}_{4}$ solution at 26.5 to $35.2{ }^{\circ} \mathrm{C}$.

To detect $\mathrm{OH}$ radicals in the reaction of $\mathrm{Pu}(\mathrm{VII})$ with water, $\mathrm{Pu}(\mathrm{VII})$ was added to 0.5 and $1.0 \mathrm{M}$ solutions of $\mathrm{NaOH}$ saturated with benzene (Bhattacharyya et al. 1982). In both cases, the product of the reaction between $\mathrm{OH}$ and benzene (i.e. phenol) was not found. It was suggested that the hydrolyzed $\mathrm{Pu}(\mathrm{VII})$ ion releases $1 / 2 \mathrm{O}_{2}$ and is converted to $\mathrm{Pu}(\mathrm{V})$. The $\mathrm{Pu}(\mathrm{V})$ then rapidly reacts with $\mathrm{Pu}(\mathrm{VII})$. It was not explained how $1 / 2 \mathrm{O}_{2}$ is abstracted from the $\mathrm{Pu}(\mathrm{VII})$ ion. The mechanism of the $\mathrm{Pu}(\mathrm{VII})$ reduction by water requires more detailed investigation.

The stability of $\mathrm{Pu}(\mathrm{VII})$ in $0.15 \mathrm{M} \mathrm{KOH}$ is unchanged by the addition of $1 \times 10^{-6} \mathrm{M}$ of $\mathrm{Cr}(\mathrm{VI}), \mathrm{Mn}(\mathrm{VII}), \mathrm{Ag}(\mathrm{I}), \mathrm{Cd}(\mathrm{II}), \mathrm{Mn}(\mathrm{II}), \mathrm{Hg}(\mathrm{II})$, or $\mathrm{Pt}(\mathrm{IV})$. Microamounts of $\mathrm{ClO}_{4}^{-}, \mathrm{SO}_{4}^{2-}$, and $\mathrm{Cl}^{-}$also have no effect on Pu(VII) stability (Komkov and Krot 1970).

$\mathrm{Pu}$ (VII) reduction is accelerated by salts of $\mathrm{Fe}(\mathrm{III}), \mathrm{Cu}$ (II), $\mathrm{Ni}(\mathrm{II})$, and $\mathrm{Co}$ (II) (Komkov and Krot 1970). The catalytic influence of Fe(III) becomes noticeable beginning from a concentration of $8 \times 10^{-7} \mathrm{M}$. The rate of Pu(VII) reduction in the presence of $\mathrm{Fe}(\mathrm{III})$ is proportional to the concentration of the latter. Similar results were obtained for compounds of copper and nickel.

The catalytic effect of iron, copper, and nickel is explained by the fact that they are able to be oxidized to higher valent states which then react rapidly with water.

The influence of cobalt on Pu(VII) stability is peculiar (Komkov and Krot 1970). The acceleration of Pu(VII) reduction becomes noticeable in $0.15 \mathrm{M} \mathrm{KOH}$ at cobalt concentrations of about $10^{-9} \mathrm{M}$. The kinetic curves for the reduction have an S-form characteristic of autocatalytic reactions. The sensitivity of $\mathrm{Pu}(\mathrm{VII})$ to the presence of cobalt decreases sharply with increasing $\mathrm{OH}^{-}$concentration. In concentrated alkali solutions, the kinetic curves for $\mathrm{Pu}(\mathrm{VII})$ reduction in the presence of cobalt have the same shape as in the case of the solutions with additions of iron, nickel, and copper. The shapes of these kinetic curves are characteristic of first-order reactions. 


\subsubsection{Reduction of $\mathrm{Np}(\mathrm{VII})$ by Sulfite}

The kinetics of the interaction between $\mathrm{Np}(\mathrm{VII})$ and $\mathrm{SO}_{3}^{2-}$ (sulfite) was studied at $0.7 \mathrm{M}$ ionic strength, 0.1 to $0.5 \mathrm{M} \mathrm{NaOH}$, and 20 to $35^{\circ} \mathrm{C}$ (Shilov and Krot 1969). Under these conditions, $\mathrm{Np}$ (VII) is reduced by excess $\mathrm{SO}_{3}^{2-}$ at a moderate rate. The initial parts of the kinetic curves are described satisfactorily by an equation for a first order reaction; it is confirmed by their linearity in semilogarithmic coordinates. However, the reduction rate at the end of the process increases. Special experiments have shown that this is because the product formed, $N p(V I)$, is converted by sulfite to $N p(V)$. The $N p(V)$ then reacts rapidly with $\mathrm{Np}(\mathrm{VII})$. The rate of the $\mathrm{Np}$ (VI) reduction by $\mathrm{SO}_{3}^{2-}$ ions is relatively low. Because of it, the autocatalytic acceleration of the reaction between $\mathrm{Np}(\mathrm{VII})$ and $\mathrm{SO}_{3}^{2}$ becomes noticeable only after the accumulation of some amount of $\mathrm{Np}(\mathrm{VI})$.

The rate constant of first order $\mathbf{k}^{\prime}$, was determined from the initial slope of the kinetic curves; the bimolecular rate constant, $\mathrm{k}$, was calculated from the ratio $\mathrm{k}^{\prime} /\left[\mathrm{SO}_{3}^{2}\right]$. Values of $\mathrm{k}$ are presented in Table 3-9. It is seen that the $\mathrm{k}$ values are constant within a wide range of sulfite concentrations, i.e. the reaction is first order relative to sulfite. The rate of the $\mathrm{Np}$ (VII) reaction with $\mathrm{SO}_{3}^{2-}$ depends strongly on $\mathrm{OH}^{-}$concentration. The $\mathrm{k}$ value can be expressed by the equation

$$
k=\frac{k_{1}}{\left[\mathrm{OH}^{-}\right]}+\frac{k_{2}}{\left[\mathrm{OH}^{-}\right]^{2}}
$$

The presentation of $\mathrm{k}$ in the form of two terms becomes reasonable if one suggests that not $\mathrm{NpO}_{4}(\mathrm{OH})_{2}^{3-}$, but products of its hydrolysis, react with sulfite:

$$
\begin{aligned}
& \mathrm{NpO}_{4}(\mathrm{OH})_{2}^{3-}+\mathrm{H}_{2} \mathrm{O} \rightleftharpoons \mathrm{NpO}_{4} \mathrm{OH}\left(\mathrm{H}_{2} \mathrm{O}\right)^{2-}+\mathrm{OH}^{-} \\
& \mathrm{NpO}_{4}(\mathrm{OH})_{2}^{3-}+2 \mathrm{H}_{2} \mathrm{O} \rightleftharpoons \mathrm{NpO}_{4}\left(\mathrm{H}_{2} \mathrm{O}\right)_{2}^{-}+2 \mathrm{OH}^{-}
\end{aligned}
$$

Plotting the temperature dependence of the $\mathrm{k}$ values in Arrhenius coordinates permits calculation of the activation energy of the $\mathrm{Np}$ (VII) reaction with $\mathrm{SO}_{3}^{2-}$. The activation energy is $94.1 \mathrm{~kJ} \mathrm{~mol}^{-1}$ (at $0.5 \mathrm{M} \mathrm{OH}$ ).

Impurities of $\mathrm{Cu}(\mathrm{II}), \mathrm{Co}(\mathrm{II})$, and $\mathrm{Mn}$ (VII) compounds have an effect on the $\mathrm{Np}$ (VII) reduction. The catalytic action of $\mathrm{Cu}$ (II) becomes noticeable at $2 \times 10^{-7} \mathrm{M}$. The reaction rate constant depends linearly on $\mathrm{Cu}(\mathrm{II})$ concentration $\left(\mathrm{CuCl}_{2}\right.$ was used):

$$
\mathrm{k}=\mathrm{k}_{\mathrm{o}}+\mathrm{k}^{\prime} /[\mathrm{Cu}(\mathrm{II})]
$$


Table 3-9. Influence of Experimental Conditions on Np(VII) Reduction Rate by Sulfite (Ionic Strength $0.7 \mathrm{M}$ with $\mathrm{NaOH}$ and $\mathrm{NaNO}_{3}$ ).

\begin{tabular}{|c|c|c|c|}
\hline Temperature, ${ }^{\circ} \mathrm{C}$ & {$\left[\mathrm{OH}^{-}\right], \mathrm{M}$} & {$\left[\mathrm{SO}_{3}^{2-}\right] \times 10^{2}, \mathrm{M}$} & $\mathrm{k}, \mathrm{M}^{-1} \mathrm{~min}^{-1}$ \\
\hline 34.9 & 0.50 & 2.20 & 1.22 \\
\hline 34.9 & 0.50 & 5.02 & 1.29 \\
\hline 34.9 & 0.50 & 7.07 & $1.31^{\mathbf{2}}$ \\
\hline 34.9 & 0.50 & 10.35 & $1.22^{\mathrm{b}}$ \\
\hline 34.9 & 0.50 & 13.50 & 0.62 \\
\hline 30.0 & 0.50 & 7.07 & 0.38 \\
\hline 25.0 & 0.50 & 7.11 & 0.60 \\
\hline 25.0 & 0.37 & 7.06 & 0.67 \\
\hline 25.0 & 0.35 & 7.15 & 0.85 \\
\hline 25.0 & 0.29 & 7.15 & 0.94 \\
\hline 25.0 & 0.25 & 7.07 & 1.38 \\
\hline 25.0 & 0.19 & 7.15 & 2.55 \\
\hline 25.0 & 0.14 & 7.15 & 3.24 \\
\hline 25.0 & 0.13 & 7.06 & 4.85 \\
\hline 25.0 & 0.10 & 7.15 & 0.19 \\
\hline 20.1 & 0.50 & 7.07 & \\
\hline 24 & & & \\
\hline
\end{tabular}

At ionic strength 0.8

${ }^{b}$ At ionic strength 0.9

where $k_{o}$ is the rate constant without the catalyst and $\mathrm{k}^{\prime}$ is $1.4 \times 10^{6} \mathrm{M}^{-2} \mathrm{~min}^{-1}$ (at $25{ }^{\circ} \mathrm{C}$ and ionic strength $0.7 \mathrm{M}$ ).

The catalytic activity of cobalt(II) and manganese(VII) is close to that of copper(II).

Besides the mentioned compounds, iron(III) is a catalyst for $\mathrm{Np}$ (VII) reduction by $\mathrm{SO}_{3}^{2-}$. However, the catalytic effect is observed at concentrations of $10^{-5} \mathrm{M}$.

Compounds of $\mathrm{Ag}(\mathrm{I})$ have no effect on the rate of reaction between $\mathrm{Np}(\mathrm{VII})$ and $\mathrm{SO}_{3}^{2-}$. 


\subsubsection{Reduction of Np(VII) by Iodide}

$\mathrm{Np}$ (VII) in solutions with alkali concentration of 1 to $3 \mathrm{M}$ does not react with $\mathrm{I}$, iodide. The oxidation properties of $\mathrm{Np}$ (VII) increases with decreasing $\mathrm{pH}$. As a result, $\mathrm{Np}$ (VII) is reduced by iodide at a moderate rate without heating at $\left(0.5\right.$ to 3) $\times 10^{-2} \mathrm{M} \mathrm{OH}^{-}$(Shilov and Krot 1969).

An induction period is observed in the reduction of $\mathrm{Np}$ (VII) by iodide. The induction period is because direct reduction of $\mathrm{Np}(\mathrm{VII})$ by $\mathrm{I}^{-}$occurs slowly. The acceleration of the reaction is connected with the formation of I oxidation products. Np(VI) does not participate in autocatalysis, since its addition to the initial solution does not change the kinetic curves.

The primary product of $\mathrm{I}^{-}$oxidation is $\mathrm{I}$, which is converted to $\mathrm{I}_{2}, \mathrm{IO}^{-}$and $\mathrm{I}_{3}$. To elucidate which of these forms catalyses the reaction, the interaction of $\mathrm{Np}$ (VII) with $\mathrm{I}_{2}$ in dilute alkaline solution in the absence and in the presence of $\mathrm{KI}$ was studied. It was found that the rate of $\mathrm{Np}(\mathrm{VII})$ reduction by a small excess of $\mathrm{I}_{2}$ without $\mathrm{KI}$ is relatively low. The addition of iodide ions accelerates the reaction sharply. From this it follows that the autocatalysis of the reaction between $\mathrm{Np}(\mathrm{VII})$ and $\mathrm{I}$ is caused by the formation and accumulation of $\mathrm{I}_{3}$. The rate of $\mathrm{Np}$ (VII) reduction by $\mathrm{I}^{-}$increases upon the addition of microamounts of cobalt(II), copper(II), and manganese(II) to the solution. The limiting concentration at which their catalytic effect becomes noticeable is about (1 to 2) $\times 10^{7} \mathrm{M}$.

\subsubsection{Reduction of Pu(VII) by Iodide}

$\mathrm{Pu}$ (VII) in $\mathrm{KOH}$ solutions is reduced by equimolar amounts of $\mathrm{KI}$ with a high rate at room temperature (Komkov et al. 1970). The reaction occurs completely even when the concentration of reducing agent is less than the Pu(VII) concentration by seven to eight-fold. Hence, all the intermediate products of $\mathrm{I}^{-}$oxidation to $\mathrm{IO}_{4}^{-}\left(\right.$or $\left.\mathrm{H}_{3} \mathrm{IO}_{6}^{2-}\right)$ are able to participate in the $\mathrm{Pu}$ (VII) reduction. This behavior is due to the high oxidation potential of the $\mathrm{Pu}(\mathrm{VII}) / \mathrm{Pu}(\mathrm{VI})$ pair. The possibility of $\mathrm{Pu}(\mathrm{VII})$ reduction by $\mathrm{IO}^{-}$and $\mathrm{IO}_{3}^{-}$was confirmed by the respective experiments.

Therefore, the interaction of Pu(VII) with I proceeds according to the stoichiometric equation:

$$
8 \mathrm{Pu}(\mathrm{VII})+\mathrm{I}^{-} \rightarrow 8 \mathrm{Pu}(\mathrm{VI})+\mathrm{I}(\mathrm{VII})
$$

If the solution contains an excess of reducing agent, the kinetics of the reaction depend considerably on the alkali concentration. At less than $2 \mathrm{M} \mathrm{KOH}$, the kinetic curves of $\mathrm{Pu}$ (VII) reduction are described by the equation:

$$
-\mathrm{d}[\mathrm{Pu}(\mathrm{VII})] / \mathrm{dt}=\mathrm{k}[\mathrm{Pu}(\mathrm{VII})]\left[\mathrm{I}^{-}\right]
$$


The $\mathrm{k}$ value for $1 \mathrm{M} \mathrm{KOH}$ at $25.0^{\circ} \mathrm{C}$ is $6.5 \times 10^{3} \mathrm{M}^{-1} \mathrm{~min}^{-1}$. Increase in the alkali concentration from 1 to $3.3 \mathrm{M}$ leads to a 50 -fold decrease in the $\mathrm{k}$ value. The temperature dependence of the $\mathrm{k}$ values corresponds to an apparent activation energy of $25 \mathrm{~kJ} \mathrm{~mol}^{-1}$.

The process of $\mathrm{Pu}$ (VII) reduction involves the reactions:

$$
\begin{gathered}
\mathrm{Pu}(\mathrm{VII})+\mathrm{I}^{-} \rightarrow \mathrm{Pu}(\mathrm{VI})+\mathrm{I} \text { (slow) } \\
\mathrm{I}+\mathrm{I}^{-} \rightarrow \mathrm{I}_{2}^{-} \text {(rapid) } \\
\mathrm{Pu}(\mathrm{VII})+\mathrm{I}_{2}^{-} \rightarrow \mathrm{Pu}(\mathrm{VI})+\mathrm{I}_{2} \text { (rapid) } \\
\mathrm{I}_{2}+2 \mathrm{OH}^{-} \rightarrow \mathrm{IO}^{-}+\mathrm{I}^{-}+\mathrm{H}_{2} \mathrm{O}
\end{gathered}
$$

The kinetic curves of the Pu(VII) reduction by excess $\mathrm{KI}$ in solutions with $\mathrm{KOH}$ concentrations higher than $2 \mathrm{M}$ are distorted and become more distorted at higher alkali concentration. The curves in $4 \mathrm{M}$ solution have an S-shape. The distortion is due to increasing participation of intermediate products of $\mathrm{I}$ oxidation in the reduction of $\mathrm{Pu}$ (VII).

\subsubsection{Reduction of Pu(VII) by Iodate}

The kinetics of $\mathrm{Pu}(\mathrm{VII})$ reduction by $\mathrm{IO}_{3}^{-}$(iodate) was studied in solutions of 0.5 to $3.5 \mathrm{M} \mathrm{KOH}$ at 15 to $35^{\circ} \mathrm{C}$ (Komkov et al. 1970). Under these conditions, the reaction proceeds irreversibly, according to the stoichiometric equation:

$$
2 \mathrm{Pu}(\mathrm{VII})+\mathrm{IO}_{3}^{-} \rightarrow 2 \mathrm{Pu}(\mathrm{VI})+\mathrm{I}(\mathrm{VII})
$$

The reaction rate is expressed by the equation:

$$
-\mathrm{d}[\mathrm{Pu}(\mathrm{VII})] / \mathrm{dt}=\mathrm{k}[\mathrm{Pu}(\mathrm{VII})]\left[\mathrm{IO}_{3}^{-}\right]
$$

The $\mathrm{k}$ value for $1 \mathrm{M} \mathrm{KOH}$ at $25{ }^{\circ} \mathrm{C}$ is $1.1 \times 10^{-3} \mathrm{M}^{-1} \mathrm{~min}^{-1}$. In the range of alkali concentration from about 0.17 to $1.7 \mathrm{M}$, the $\mathrm{k}$ value decreases inversely with $\mathrm{OH}^{-}$ concentration. The $\mathrm{k}$ value then remains constant up to about $3.5 \mathrm{M}$.

The rate of $\mathrm{Pu}(\mathrm{VII})$ reduction by $\mathrm{IO}_{3}^{-}$increases relatively slowly with increasing temperature. The apparent activation energy for the reaction in $2.5 \mathrm{M} \mathrm{KOH}$ is $24 \mathrm{~kJ} \mathrm{~mol}^{-1}$. 
The mechanism of $\mathrm{Pu}(\mathrm{VII})$ reduction may be presented by the reactions:

$$
\begin{aligned}
& \mathrm{Pu}(\mathrm{VII})+\mathrm{IO}_{3}^{-} \rightarrow \mathrm{Pu}(\mathrm{VI})+\mathrm{I}(\mathrm{VI}) \text { (slow) } \\
& \mathrm{Pu}(\mathrm{VII})+\mathrm{I}(\mathrm{VI}) \rightarrow \mathrm{Pu}(\mathrm{VI})+\mathrm{I}(\mathrm{V}) \text { (rapid) }
\end{aligned}
$$

\subsubsection{Reduction of $\mathrm{Np}(\mathrm{VI})$ and $\mathrm{Pu}(\mathrm{VII})$ by Organic Compounds}

The kinetics of the reactions of $\mathrm{Np}$ (VII) with aliphatic alcohols, formaldehyde, and formate in alkaline solutions was studied (Tananaev 1989; Tananaev 1990b; Tananaev 1990c;

Tananaev 1990d; Tananaev 1990e; Tananaev 1990f); the kinetics of the reaction of Pu(VII) with methanol and ethanol also has been investigated (Tananaev 1992). The reaction rates for all studied systems are described by the equation:

$$
-\mathrm{d} \ln [\mathrm{An}(\mathrm{VII})] / \mathrm{dt}=\mathrm{k}
$$

or

$$
-\mathrm{d} \ln [\mathrm{An}(\mathrm{VII})] / \mathrm{dt}=\mathrm{k}_{\mathrm{o}}[\mathrm{Red}]^{\mathrm{n}}\left[\mathrm{OH}^{-}\right]^{\mathrm{m}}
$$

where Red is the reducing agent, $\mathrm{k}_{\mathrm{o}}$ is the rate constant at $1 \mathrm{M}$ Red, and $\mathrm{OH}^{-}$concentration is expressed in $\mathrm{M}\left(\right.$ at $\left.25^{\circ} \mathrm{C}\right)$.

All the reactions are decelerated with increasing alkali concentration and are accelerated by increasing concentrations of reducing agents and temperature. In Tables 3-10 and 3-11, the kinetic parameters of reactions of $\mathrm{Np}$ (VII) and $\mathrm{Pu}(\mathrm{VII})$, respectively, are shown.

From Table 3-10 it is seen that normal alcohols with an odd number of carbon atoms are oxidized faster than alcohols with an even number of these atoms. Secondary alcohols, except isopropanol, and the products of alcohol oxidation are more reactive than normal alcohols.

$\mathrm{Pu}$ (VII), like Np(VII), reacts slower with ethanol than with methanol. The rate constants of the Pu(VII) reduction by the respective alcohols are about 100 times higher than the analogous rate constants for the $\mathrm{Np}$ (VII) reduction. 
Table 3-10. Kinetic Parameters for Np(VII) Reduction by Organic Compounds.

\begin{tabular}{|c|c|c|c|c|c|c|c|c|c|}
\hline $\begin{array}{l}\text { Reducing } \\
\text { agent }\end{array}$ & $\begin{array}{c}\text { [Red], } \\
\mathrm{M}\end{array}$ & $\begin{array}{c}{[\mathrm{KOH}]} \\
\mathbf{M}\end{array}$ & $\mathrm{T},{ }^{\circ} \mathrm{C}$ & $\begin{array}{c}\mathbf{k} \times 10^{2} \\
\min ^{-1}\end{array}$ & $\mathbf{n}$ & $\mathbf{m}$ & $\begin{array}{l}\mathrm{E}, \mathrm{kJ} \\
\mathrm{mol}^{-1}\end{array}$ & $\underset{\min ^{-1}}{\mathbf{k}_{0} \times 10^{4}}$ & Reference $^{b}$ \\
\hline $\mathrm{CH}_{3} \mathrm{OH}$ & 16.4 & 1.0 & 28.2 & 3.84 & 0.74 & -1.5 & 50.7 & 44.0 & [1] \\
\hline $\mathrm{C}_{2} \mathrm{H}_{5} \mathrm{OH}$ & 3.4 & 1.0 & 38.9 & 0.69 & 1.5 & -1.1 & 49.7 & 4.47 & [1] \\
\hline$n-\mathrm{C}_{3} \mathrm{H}_{7} \mathrm{OH}$ & 0.28 & 1.0 & 60.4 & 0.80 & 0.9 & -0.96 & 46.3 & 34.5 & [2] \\
\hline$n-\mathrm{C}_{4} \mathrm{H}_{9} \mathrm{OH}$ & 0.22 & 1.0 & 60.4 & 0.28 & 0.6 & -1.0 & 58.4 & 5.77 & [3] \\
\hline$n-C_{9} H_{11} \mathrm{OH}$ & 0.10 & 1.0 & 60.4 & 0.14 & 0.8 & -1.0 & 81.4 & 2.71 & [3] \\
\hline$i-\mathrm{C}_{3} \mathrm{H}_{7} \mathrm{OH}$ & 0.26 & 1.0 & 55.6 & 0.37 & 0.8 & -1.0 & 52 & 16.4 & [4] \\
\hline$i-\mathrm{C}_{4} \mathrm{H}_{9} \mathrm{OH}$ & 0.22 & 1.0 & 55.6 & 0.23 & 0.8 & -1.0 & 54 & 10.9 & [4] \\
\hline$i-\mathrm{C}_{5} \mathrm{H}_{11} \mathrm{OH}$ & 0.11 & 0.5 & 60.4 & 0.40 & 1.0 & -0.95 & 71 & 9.0 & [2] \\
\hline $\mathrm{CH}_{2} \mathrm{O}$ & 0.0075 & 1.0 & 29.6 & 1.23 & 1.0 & -1.0 & 59 & $1.14 \times 10^{4}$ & [5] \\
\hline$\left(\mathrm{CH}_{3}\right)_{2} \mathrm{CO}$ & 0.27 & $1.0^{2}$ & 30.3 & 0.42 & 0.9 & -1.0 & 49 & 96 & [5] \\
\hline HCOONa & 0.01 & 0.2 & 65.0 & 1.45 & 0.6 & -0.33 & 56 & 93 & [6] \\
\hline
\end{tabular}

${ }^{2} \mathrm{NaOH}$ was used

'References:
[1] Tananaev 1989
[2] Tananaev $1990 \mathrm{e}$
[3] Tananaev $1990 \mathrm{c}$
[4] Tananaev 1990d
[5] Tananaev $1990 \mathrm{f}$
[6] Tananaev 1990b

Table 3-11. Influence of the Nature of the Alcohol on the Kinetics of Pu(VII) Reduction (Tananaev 1992).

\begin{tabular}{|c|c|c|c|c|c|c|c|c|}
\hline Alcohol & {$[\mathrm{ROH}] \times 10^{2}, \mathrm{M}$} & {$[\mathrm{NaOH}], \mathrm{M}$} & $\mathrm{T},{ }^{\circ} \mathrm{C}$ & $\begin{array}{c}\mathrm{k} \times 10^{2}, \\
\mathrm{~min}^{-1}\end{array}$ & $\mathrm{n}$ & $\mathrm{m}$ & $\mathrm{E}, \mathrm{kJ} \mathrm{mol}$ & $\begin{array}{c}\mathrm{k}_{\mathrm{o}} \times 10^{4}, \\
\mathrm{~min}^{-1}\end{array}$ \\
\hline $\mathrm{CH}_{3} \mathrm{OH}$ & 3.4 & 0.95 & 25.2 & 0.26 & 1.5 & -0.3 & 50 & $4 \times 10^{3}$ \\
\hline $\mathrm{C}_{2} \mathrm{H}_{5} \mathrm{OH}$ & 2.4 & 0.94 & 25.2 & 0.23 & 0.94 & -0.8 & 44 & $6.3 \times 10^{2}$ \\
\hline
\end{tabular}




\subsubsection{List of Methods for the Preparation of Actinides in Selected Oxidation States}

Several methods are available to prepare actinides in selected oxidation states in alkaline media:

1. By the addition of alkali solution to slightly-acid solutions of U(IV), U(VI), Np(IV), $\mathrm{Np}(\mathrm{VI}), \mathrm{Pu}(\mathrm{III}), \mathrm{Pu}(\mathrm{IV}), \mathrm{Pu}(\mathrm{VI}), \mathrm{Am}(\mathrm{III}), \mathrm{Am}(\mathrm{V}), \mathrm{Am}(\mathrm{VI})$.

2. By electrochemical oxidation or reduction in alkaline media.

3. By the oxidation of actinide(III), (IV), (V) by ozone, $\mathrm{KBrO}$, or other strong oxidizing agents.

4. By the reduction of $\mathrm{Np}(\mathrm{VII}), \mathrm{Np}(\mathrm{VI}), \mathrm{Pu}(\mathrm{VII}), \mathrm{Pu}(\mathrm{VI}), \mathrm{Am}(\mathrm{VII}), \mathrm{Am}(\mathrm{VI})$ by hydrogen peroxide or the other suitable reagent.

Table 3-12 shows some examples of the preparation of actinide ions in selected oxidation states.

Table 3-12. Methods for the Preparation of Actinides in Selected Oxidation States in Alkaline Media.

\begin{tabular}{|c|c|c|}
\hline Element & Oxidation state & Method of preparation \\
\hline \multirow[t]{2}{*}{ Uranium } & $\overline{\mathrm{U}(\mathrm{IV})}$ & 1. $\mathrm{U}^{4}+\mathrm{OH}^{-}$in inert atmosphere \\
\hline & $\overline{U(V I)}$ & $\begin{array}{l}\text { 1. } \mathrm{UO}_{2}^{2+}+\mathrm{OH}^{-} \\
\text {2. Oxidation of } \mathrm{UO}_{2} \cdot \mathrm{xH}_{2} \mathrm{O} \text { by atmospheric oxygen } \\
\text { or other suitable oxidizing agent }\end{array}$ \\
\hline \multirow[t]{3}{*}{ Neptunium } & $\mathrm{Np}(\mathrm{IV})$ & $\begin{array}{l}\text { 1. } \mathrm{Np}^{4+}+\mathrm{OH}^{-} \text {in inert atmosphere } \\
\text { 2. } \mathrm{Np}(\mathrm{V})+\mathrm{e}^{-} \text {(Pt cathode) }\end{array}$ \\
\hline & $\mathrm{Np}(\mathrm{V})$ & $\begin{array}{ll}\text { 1. } & \mathrm{NpO}_{2}^{+}+\mathrm{OH}^{-} \\
\text {2. } & \mathrm{Np}(\mathrm{VI})+\mathrm{e}^{-}(\mathrm{Pt} \text { cathode }) \\
\text { 3. } & \mathrm{Np}(\mathrm{VI})+\mathrm{H}_{2} \mathrm{O}_{2} \\
\text { 4. } & \mathrm{Np}(\mathrm{VI})+\mathrm{SO}_{3}^{2-} \\
\text { 5. } & \left.\mathrm{Np}(\mathrm{IV})+\mathrm{Np}^{2} \mathrm{VI}\right)\end{array}$ \\
\hline & $\mathrm{Np}(\mathrm{VI})$ & $\begin{array}{ll}\text { 1. } & \mathrm{NpO}_{2}^{2+}+\mathrm{OH}^{-} \\
\text {2. } & \mathrm{Np}(\mathrm{V})+\mathrm{O}_{3}, \mathrm{CO}_{3}^{-}, \text {or } \mathrm{O}^{-} \\
\text {3. } & \mathrm{Np}(\mathrm{V})+\mathrm{BrO}^{-} \\
\text {4. } & \mathrm{Np}(\mathrm{V})+\mathrm{S}_{2} \mathrm{O}_{8}^{2} \text { and so on } \\
\text { 5. } & \mathrm{Np}(\mathrm{VII})+\mathrm{H}_{2} \mathrm{O}_{2} \\
\text { 6. } & \mathrm{Np}(\mathrm{VII})+\mathrm{N}_{2} \mathrm{H}_{4}, \mathrm{NH}_{2} \mathrm{OH}, \mathrm{SO}_{3}^{2-} \text { and so on } \\
\text { 7. } & \mathrm{Radiolysis} \text { of aerated } \mathrm{Np}(\mathrm{VII}) \text { solutions } \\
\text { 8. } & \mathrm{Np}(\mathrm{V})+\mathrm{Np}(\mathrm{VII})\end{array}$ \\
\hline
\end{tabular}


Table 3-12. Methods for the Preparation of Actinides in Selected Oxidation States in Alkaline Media.

\begin{tabular}{|c|c|c|}
\hline Element & Oxidation state & Method of preparation \\
\hline $\begin{array}{l}\text { Neptunium } \\
\text { (cont'd) }\end{array}$ & $\mathrm{Np}(\mathrm{VII})$ & $\begin{array}{ll}\text { 1. } & \text { Dissolution of } \mathrm{Li}_{5} \mathrm{NpO}_{6} \text { in alkaline solutions } \\
\text { 2. } & \text { Anodic oxidation of } \mathrm{Np}(\mathrm{VI}) \text { in alkaline } \\
\text { 3. } & \mathrm{Np}(\mathrm{VI})+\mathrm{O}_{3} \\
\text { 4. } & \mathrm{Np}(\mathrm{VI})+\mathrm{S}_{2} \mathrm{O}_{8}^{2-} \\
\text { 5. } & \mathrm{Np}(\mathrm{VI})+\mathrm{BrO}^{-} \\
\text {6. } & \mathrm{Np}(\mathrm{VI})+\mathrm{O}^{-} \\
\text {7. } & \mathrm{Np}(\mathrm{VI})+\mathrm{Pu}(\mathrm{VII}) \\
\text { 8. } & \mathrm{Np}(\mathrm{VI})+\mathrm{Pu}(\mathrm{VI}) \\
\text { 9. } & \mathrm{Np}(\mathrm{VI})+\mathrm{Am}(\mathrm{VII}) \\
\text { 10. } & \mathrm{Np}(\mathrm{VI})+\mathrm{Am}(\mathrm{VI}) \\
\text { 11. } & \mathrm{Np}(\mathrm{VI})+\mathrm{MnO}- \\
\text { 12. } & \mathrm{Np}(\mathrm{VI})+\mathrm{Fe}(\mathrm{CN})_{6}^{3-} \\
\text { 13. } & \mathrm{Np}(\mathrm{VI})+\mathrm{AgO}^{-} \\
\text {14. } & \mathrm{Np}(\mathrm{VI})+\mathrm{Ag}_{2} \mathrm{O} \text { and so on } \\
\text { 15. } & 2 \mathrm{~Np}(\mathrm{VI}) \rightleftarrows \mathrm{Np}(\mathrm{VII})+\mathrm{Np}(\mathrm{V})\end{array}$ \\
\hline \multirow[t]{4}{*}{ Plutonium } & $\mathrm{Pu}(\mathrm{III})$ & $\begin{array}{l}\text { 1. } \mathrm{Pu}^{3+}+\mathrm{OH}^{-} \text {in inert atmosphere } \\
\text { 2. } \mathrm{Pu}(\mathrm{IV})+\mathrm{e}^{-} \text {(Pt cathode) }\end{array}$ \\
\hline & $\mathrm{Pu}(\mathrm{IV})$ & $\begin{array}{ll}\text { 1. } & \mathrm{Pu}^{4+}+\mathrm{OH}^{-} \\
\text {2. } & \mathrm{Pu}(\mathrm{III})+\text { oxidizing agent }\left(\mathrm{O}_{2} \text { and so on }\right) \\
\text { 3. } & \left.\mathrm{Pu}(\mathrm{V})+\mathrm{e}^{-} \text {(Pt cathode }\right)\end{array}$ \\
\hline & $\mathrm{Pu}(\mathrm{V})$ & $\begin{array}{ll}\text { 1. } & \mathrm{PuO}_{2}^{+}+\mathrm{OH}^{-} \\
\text {2. } & \mathrm{Pu}(\mathrm{IV})+\mathrm{Pu}(\mathrm{VI}) \\
\text { 3. } & \mathrm{Pu}(\mathrm{VI})+\mathrm{H}_{2} \mathrm{O}_{2} \\
\text { 4. } & \text { Radiolysis of aerated } \mathrm{Pu}(\mathrm{VI}) \text { solutions }\end{array}$ \\
\hline & $\mathrm{Pu}(\mathrm{VI})$ & $\begin{array}{ll}\text { 1. } & \mathrm{PuO}_{2}^{2+}+\mathrm{OH}^{-} \\
\text {2. } & \mathrm{Pu}(\mathrm{V})+\mathrm{O}_{3} \\
\text { 3. } & \mathrm{Pu}(\mathrm{V})+\mathrm{O}^{-} \\
\text {4. } & \mathrm{Pu}(\mathrm{V})+\mathrm{S}_{2} \mathrm{O}_{8}^{2-}, \mathrm{BrO}^{-} \text {and so on } \\
\text { 5. } & \mathrm{Pu}(\mathrm{VII})+\mathrm{H}_{2} \mathrm{O}_{2} \\
\text { 6. } & \text { Radiolysis of aerated } \mathrm{Pu}(\mathrm{VII}) \text { solutions } \\
\text { 7. } & \text { Anodic oxidation of } \mathrm{Pu}(\mathrm{V}) \\
\text { 8. } & \mathrm{Pu}(\mathrm{VII})+\mathrm{e}^{-}(\mathrm{Pt} \text { cathode) } \\
\text { 9. } & \mathrm{Pu}(\mathrm{V})+\mathrm{Pu}(\mathrm{VII})\end{array}$ \\
\hline
\end{tabular}


Table 3-12. Methods for the Preparation of Actinides in Selected Oxidation States in Alkaline Media.

\begin{tabular}{|c|c|c|}
\hline Element & Oxidation state & Method of preparation \\
\hline $\begin{array}{c}\text { Plutonium } \\
\text { (cont'd) }\end{array}$ & $\mathrm{Pu}(\mathrm{VII})$ & $\begin{array}{ll}\text { 1. } & \text { Dissolution of } \mathrm{Cs}_{3} \mathrm{PuO}_{5} \text { in alkaline solutions } \\
\text { 2. } & \text { Anodic oxidation of } \mathrm{Pu}(\mathrm{VI}) \text { in alkaline } \\
\text { 3. } & \mathrm{Pu}(\mathrm{VI})+\mathrm{O}_{3} \\
\text { 4. } & \mathrm{Pu}(\mathrm{VI})+\mathrm{O}^{-} \\
\text {5. } & \mathrm{Pu}(\mathrm{VI})+\mathrm{S}_{2} \mathrm{O}_{8}^{2-} \\
\text { 6. } & \mathrm{Pu}(\mathrm{VI})+\mathrm{BrO}^{-} \\
\text {7. } & \mathrm{Pu}(\mathrm{VI})+\mathrm{AgO} \\
\text { 8. } & \left.\mathrm{Pu}(\mathrm{VI})+\mathrm{Am}^{\mathrm{V}} \mathrm{VI}\right) \\
\text { 9. } & \mathrm{Pu}(\mathrm{VI})+\mathrm{MnO}_{4}^{-} \text {and so on }\end{array}$ \\
\hline \multirow[t]{5}{*}{ Americium } & Am(III) & 1. $\mathrm{Am}^{3+}+\mathrm{OH}^{-}$ \\
\hline & $\overline{A m(I V)}$ & $\begin{array}{ll}\text { 1. } & \mathrm{Am}(\mathrm{III})+\mathrm{Fe}(\mathrm{CN})_{6}^{3-} \text { (in equimolar amounts) } \\
\text { 2. } & \mathrm{Am}(\mathrm{III})+\mathrm{ClO}^{-} \\
\text {3. } & \mathrm{Am}(\mathrm{III})+\mathrm{H}_{2} \mathrm{O}_{2} \\
\text { 4. } & \mathrm{Am}(\mathrm{III})+\mathrm{MnO}_{4}^{-}\end{array}$ \\
\hline & $\mathrm{Am}(\mathrm{V})$ & $\begin{array}{ll}\text { 1. } & \mathrm{AmO}_{2}^{+}+\mathrm{OH}^{-} \\
\text {2. } & \mathrm{Am}(\mathrm{VI})+\mathrm{H}_{2} \mathrm{O}_{2} \\
\text { 3. } & \mathrm{Am}(\mathrm{VI})+\mathrm{H}_{2} \mathrm{O} \\
\text { 4. } & \text { Radiolysis of aerated } \mathrm{Am}(\mathrm{VI}) \text { solutions } \\
\text { 5. } & \mathrm{Am}(\mathrm{VI})+\mathrm{e}^{-}(\mathrm{Pt} \text { cathode) } \\
\text { 6. } & \mathrm{Am}(\mathrm{III})+\mathrm{Fe}(\mathrm{CN})_{6}^{3} \text { (in excess) }\end{array}$ \\
\hline & $\overline{A m}(\mathrm{VI})$ & $\begin{array}{ll}\text { 1. } & \mathrm{AmO}_{2}^{2+}+\mathrm{OH}^{-} \\
\text {2. } & \mathrm{Am}(\mathrm{III})+\mathrm{O}_{3} \\
\text { 3. } & \text { Anodic oxidation of } \mathrm{Am}(\mathrm{III}) \\
\text { 4. } & \mathrm{Am}(\mathrm{V})+\mathrm{O}^{-} \\
\text {5. } & \mathrm{Am}(\mathrm{VII})+\mathrm{H}_{2} \mathrm{O} \\
\text { 6. } & \mathrm{Am}(\mathrm{V})+\mathrm{O}_{3}\end{array}$ \\
\hline & $\mathrm{Am}$ (VII) & $\begin{array}{ll}\text { 1. } & \mathrm{Am}(\mathrm{VI})+\mathrm{O}_{3} \\
\text { 2. } & \mathrm{Am}(\mathrm{VI})+\mathrm{O}^{-} \\
\text {3. } & 2 \mathrm{Am}(\mathrm{VI}) \rightleftharpoons \mathrm{Am}(\mathrm{VII})+\mathrm{Am}(\mathrm{V})\end{array}$ \\
\hline
\end{tabular}




\subsection{REFERENCES}

Bhattacharyya, P. K., R. Veeraghavan, and R. D. Saini, 1982, Radiochimica Acta, 30, 217.

Blokhin, V. I., N. N. Krot, and A. D. Gel'man, 1970, Radiochimiya, 12, 792.

Bourges, J., 1972, Radiochem. Radioanal. Lett., 12, 111.

Buijs, K., and K. Louwrier, 1966, J. Inorg. Nucl. Chem., 28, 2463.

Chaikhorsky, A. A., M. Yu. Matuzenko, and Yu. I. Belyaev, 1974, Radiochimiya, 16, 850.

Cohen, D., and S. Fried, 1969, Inorg. Nucl. Chem. Lett., 5, 653.

Cunningham B. B., 1949, The Transuranium Elements, Ed. G. T. Seaborg, J. J. Katz, and W. M. Manning, Nat'l. Nucl. En. Ser., Div IV, Vol. 14B, p. 1363, McGraw-Hill Book Co., Inc., New York, New York.

Delegard, C. H., 1987, Radiochimica Acta, 41, 11.

Ermakov, V. S., T. N. Bukhtiyarova, and N. N. Krot, 1977, Radiokhimiya, 19, 250.

Gogolev, A. V., V. P. Shilov, and A. K. Pikaev, 1989, Radiokhimiya, 31, No. 1, 124.

Gusev, Yu. K., V. F. Peretrukhin, V. P. Shilov, and I. S. Kirin, 1972, Radiokhimiya, 14, 888.

Hart, E. J., and M. Anbar, 1970, The Hydrated Electron, Wiley, New York, New York.

Klimov, V. D., V. N. Prusakov, and V. B. Sokolov, 1971, Radiokhimiya, 13, 725.

Kolthoff, I. M., and I. K. Miller, 1951, J. Am. Chem. Soc., 73, 3055.

Komkov, Yu. A., and N. N. Krot, 1970, Radiokhimiya, 12, 227.

Komkov, Yu. A., N. N. Krot, and A. D. Gel'man, 1970, Radiokhimiya, 12, 692.

Komkov, Yu. A., A. N. Krot, and A. D. Gel'man, 1968, Radiokhimiya, 10, 625.

Komkov, Yu. A., V. F. Peretrukhin, N. N. Krot, and A. D. Gel'man, 1969, Radiokhimiya, $\underline{11}, 407$.

Krot, N. N., and A. D. Gel'man, 1967, Dokl. Akad. Nauk SSSR, 177, 124. 
Krot, N. N., A. D. Gel'man, M. P. Mefod'eva, V. P. Shilov, V. F. Peretrukhin, and V. I. Spitsyn, 1977a, Semivalentnoe Sostayanie Neptuniya, Plutoniya, Ameritsiya, Nauka, Moscow, USSR, (in Russian). Available in English as Heptavalent State of Neptunium, Plutonium, and Americium, UCRL-Trans-11798, Lawrence Livermore National Laboratory, Livermore, California.

Krot, N. N., M. P. Mefod'eva, and T. V. Afanas'eva, 1977b, Radiokhimiya, 19, 230.

Krot, N. N., M. P. Mefod'eva, V. P. Shilov, and A. D. Gel'man, 1970, Radiokhimiya, 12, 471.

Krot, N. N., M. P. Mefod'eva, T. V. Smirnova, and A. D. Gel'man, 1968, Radiokhimiya, 10,412 .

Krot, N. N., V. P. Shilov, V. B. Nikolaevsky, A. D. Gel'man, A. K. Pikaev, and V. I. Spitsyn, 1974, Dokl. Akad. Nauk SSSR, 217, 589.

Kulyako, Yu. M., T. I. Trofimov, D. A. Malikov, I. A. Lebedev, and B. F. Myasoedov, 1993, Radiokhimiya, 35, No. 5, 68.

Mefod'eva, M. P., N. N. Krot, and T. V. Afanas'eva, 1977, Radiokhimiya, 19, 245.

Nikolaevsky, V. B., V. P. Shilov, N. N. Krot, and V. F. Peretrukhin, 1975, Radiokhimiya, $17,431$.

Nikolaevsky, V. B., V. P. Shilov, and N. N. Krot, 1974, Radiokhimiya, 16, 122.

Penneman, R. A., J. S. Coleman, and T. K. Keenan, 1961, J. Inorg. Nucl. Chem., 17, 138.

Penneman, R. A., and L. B. Asprey, 1955, Proc. First Intern. Conf. Peaceful Uses of Atomic Energy, IAEA, Geneve, Switzerland, paper P/838.

Peretrukhin, V. F., N. N. Krot, and A. D. Gel'man, 1971, Radiokhimiya, 13, 772.

Shashukov, E. A., and A. A. Kozlov, 1970, Radiokhimiya, 12, 237.

Shatokhina, O. B., D. P. Alekseeva, V. F. Peretrukhin, and N. N. Krot, 1977, Radiokhimiya, 19, 824.

Shilov, V. P., E. S. Stepanova, and N. N. Krot, 1977, Radiokhimiya, $19,80$.

Shilov, V. P., 1976, Radiokhimiya, 18, 688.

Shilov, V. P., N. N. Krot, and A. D. Gel'man, 1971, Radiokhimiya, 13, 9. 
Shilov, V. P., N. N. Krot, and A. D. Gel'man, 1970a, Radiokhimiya, 12, 896.

Shilov, V. P., N. N. Krot, and A. D. Gel'man, 1970b, Radiokhimiya, 12, 911.

Shilov, V. P., and N. N. Krot, 1969, Radiokhimiya, 11, 399.

Spitsyn, V. I., N. N. Krot, M. P. Mefod'eva, and A. D. Gel'man, 1968, Dokl. Akad. Nauk SSSR, 181, 128.

Tananaev, I. G., 1992, Radiokhimiya, 4, No. 1, 108.

Tananaev, I. G., 1990a, Radiokhimiya, 32, No.1, 20.

Tananaev, I. G., 1990c, Radiokhimiya, 32, No. 2, 7.

Tananaev, I. G., 1990b, Radiokhimiya, 2, No. 1, 23.

Tananaev, I. G., 1990d, Radiokhimiya, 32, No. 5, 43.

Tananaev, I. G., 1990e, Radiokhimiya, 32, No. 5, 46.

Tananaev, I. G., 1990f, Radiokhimiya, 32, No. 5, 50.

Tananaev, I. G., 1989, Radiokhimiya, 31, No. 4, 62.

Zielen, A. J., and D. Cohen, 1970, J. Phys. Chem., 74, 394. 


\subsection{ELECTROCHEMICAL REACTIONS OF ACTINIDES AND TECHNETIUM IN ALKALINE MEDIA}

A large body of data exists in the literature on actinide electrochemistry in alkaline media. Different redox actinide reactions are investigated, using electrochemical techniques. The electrochemical preparation methods for solid actinide compounds and for actinide stabilization in selected oxidation states are developed. Electrochemical methods, developed for alkaline solutions, are reported to be widely used in radioanalytical chemistry (actinide hydroxides electrodeposition for alpha-spectrometric source preparation) and in non-nuclear analytical chemistry of actinides (voltametric techniques for quantitative determination). At the same time, literature data on technetium behavior in alkaline media are much more restricted.

\subsection{MECHANISM OF ELECTROCHEMICAL REACTIONS OF ACTINIDES IN ALKALINE MEDIA}

Voltammetry at platinum and dropping mercury electrodes has been used to investigate actinide electrochemical reactions in alkaline media. Using voltametric techniques and $\mathrm{Pt}$ microelectrodes, $\mathrm{Np}(\mathrm{VII}), \mathrm{Pu}(\mathrm{VII})$, and $\mathrm{Am}(\mathrm{VI})$ were found to be reduced in alkaline media according to a step-by-step mechanism with transfer of one electrode at each step of the reaction:

$$
\mathrm{Np}(\mathrm{VII})+\mathrm{e}^{-} \rightarrow \mathrm{Np}(\mathrm{VI})+\mathrm{e}^{-} \rightarrow \mathrm{Np}(\mathrm{V})+\mathrm{e}^{-} \rightarrow \mathrm{Np}(\mathrm{IV})
$$

(Simakin and Matyashchuk 1969; Zielen and Cohen 1970; and Peretrukhin and Alekseeva 1974a)

$$
\mathrm{Pu}(\mathrm{VII})+\mathrm{e}^{-} \rightarrow \mathrm{Pu}(\mathrm{VI})+\mathrm{e}^{-} \rightarrow \mathrm{Pu}(\mathrm{V})+\mathrm{e}^{-} \rightarrow \mathrm{Pu}(\mathrm{IV})+\mathrm{e}^{-} \rightarrow \mathrm{Pu}(\mathrm{III})
$$

(Cook et al. 1958; and Peretrukhin and Alekseeva 1974b)

$$
\mathrm{Am}(\mathrm{VI})+\mathrm{e}^{-} \rightarrow \mathrm{Am}(\mathrm{V})+\mathrm{e}^{-} \rightarrow \mathrm{Am}(\mathrm{IV})+\mathrm{e}^{-} \rightarrow \mathrm{Am}(\mathrm{III})
$$

(Peretrukhin et al. 1974)

Processes of $A n(V I I) / A n(V I)$ reduction in alkaline solutions are found to be either irreversible or quasi-reversible. $\mathrm{An}(\mathrm{VI}) / \mathrm{An}(\mathrm{V})$ reduction is characterized by reversibility, but the further reduction of $\mathrm{Pu}(\mathrm{V})$ and $\mathrm{Am}(\mathrm{V})$ is completely irreversible. The reduction mechanism of $\mathrm{Np}(\mathrm{V})$ in 1 to $10 \mathrm{M} \mathrm{NaOH}$ has not been determined yet, since this process was proved to occur at negative electrode potentials (less than $-1.0 \mathrm{~V} \mathrm{SHE}$ ); impossible to study due to the intense hydrogen evolution. 
Formation and adhesion of poorly soluble $\mathrm{An}(\mathrm{V})$ hydroxides on the electrode surface in 0.1 to $2.5 \mathrm{M} \mathrm{NaOH}$ and 0.1 to $1.0 \mathrm{M} \mathrm{LiOH}$ are observed in An(VI) electrochemical reduction in alkaline media. This effect diminishes the values of limiting currents for the processes under study. The adhesion was found to be strong. Nevertheless, the An(V) hydroxide layers may be removed from the electrode after polarization at a potential sufficiently positive to oxidize An(V) to An(VI).

The mechanism of technetium(VII) electrochemical reduction in weakly alkaline media $(8<\mathrm{pH}<11)$ also was found to be a chain of one electron transfers.

$$
\mathrm{TcO}_{4}^{-}+\mathrm{e}^{-} \rightarrow \mathrm{TcO}_{4}^{2-}+\mathrm{e}^{-} \rightarrow \mathrm{TcO}_{3}^{-}+\mathrm{e}^{-} \rightarrow \mathrm{TcO}_{2} \cdot \mathrm{xH}_{2} \mathrm{O}
$$

This sequential reduction is found to be complicated by disproportionation. As described in Section $2.0, \mathrm{Tc}(\mathrm{VI})$ is thermodynamically unstable in alkaline media and tends to disproportionate according to the reaction

$$
2 \mathrm{Tc}(\mathrm{VI}) \rightarrow \mathrm{Tc}(\mathrm{V})+\mathrm{Tc}(\mathrm{VII})
$$

In solutions with $\mathrm{pH}$ greater than 12 , the rate of $\mathrm{Tc}(\mathrm{VI})$ disproportionation becomes so high that the limiting current of the polarographic wave, corresponding to $\mathrm{Tc}(\mathrm{VII}) / \mathrm{Tc}(\mathrm{VI})$, is found to be 2 times greater than that for the further reduction step $\mathrm{Tc}(\mathrm{VI})+\mathrm{e}^{-} \rightarrow \mathrm{Tc}(\mathrm{V})$. In these electrolytes, voltametric techniques may indicate only two steps of the reduction process (Zhdanov et al. 1970; Founta et al. 1987):

$$
\mathrm{TcO}_{4}^{-}+2 \mathrm{e}^{-} \rightarrow \mathrm{Tc}(\mathrm{V})+\mathrm{e}^{-} \rightarrow \mathrm{Tc}(\mathrm{IV})
$$

If the $\mathrm{pH}$ of the supporting electrolyte is increased from 12 to 14 , the half-wave potential of $\mathrm{Tc}(\mathrm{VII}) / \mathrm{Tc}(\mathrm{V})$ reduction shifts from $-0.56 \mathrm{~V}$ vs. SHE at the rate of $80 \mathrm{mV} / \mathrm{pH}$. This shift indicates the participation of $\mathrm{OH}^{-}$ions in the electrochemical reduction of $\mathrm{TcO}_{4}^{-}$to $\mathrm{TcO}_{2} \cdot \mathrm{xH}_{2} \mathrm{O}$. The latter compound in 0.1 to $1.0 \mathrm{M} \mathrm{NaOH}$ solutions, containing up to $10^{-3} \mathrm{M}$ Tc(VII), was found not to form an insoluble film on the dropping mercury electrode surface, when the drop rate was changed from 0.5 to $1 \mathrm{~s}^{-1}$. This in turn indicates a significant solubility of precipitated Tc(IV) hydroxide deposited at the electrode as a product of Tc(V) electrolysis (Founta et al. 1987).

\subsection{ELECTROCHEMICAL PREPARATION OF An(VII), An(VI) AND An(V) (An=Np, Pu, Am) ALKALINE SOLUTIONS}

Alkaline sludge, containing $\mathrm{NpO}_{2}$ (or $\mathrm{PuO}_{2}$ ) calcined powders or freshly prepared actinide(IV) hydroxides, were used as starting materials. Electrochemical cells with compartments separated by porous glass or anion exchange membranes and a $\mathrm{Pt}$ gauze anode, 
were specially designed for An(III) and An(IV) oxidation in alkaline media. The Pt anode occupied approximately $25 \%$ of the anode compartment volume and the surface to volume (S/V) ratios ranged from 0.5 to $0.6 \mathrm{~cm}^{2} / \mathrm{mL}$.

When calcined actinide dioxide powders were used (Shvedov and Seregin 1972; and Peretrukhin 1980), the oxidation process was slow, requiring 6 to 40 hours. The rate of dissolution was unaffected by anodic current density in the range 1 to $10 \mathrm{~mA} / \mathrm{cm}^{2}$ for $\mathrm{Np}$ and in the range 5 to $20 \mathrm{~mA} / \mathrm{cm}^{2}$ for $\mathrm{Pu}$. The accumulation of $\mathrm{An}(\mathrm{V})$ and $\mathrm{An}(\mathrm{VI})$ soluble species in the solution was noticed in the first hours of the process. About (1 to 2) $\times 10^{3} \mathrm{M} \mathrm{Np}$ (VII) or $\mathrm{Pu}(\mathrm{VII})$ with (3 to 6$) \times 10^{-5} \mathrm{M} \mathrm{Np}(\mathrm{VI})$ or $\mathrm{Pu}(\mathrm{VI})$ in 1 to $4 \mathrm{M} \mathrm{NaOH}$ were found to be the final products of this electrochemical process. About 2 to $3 \%$ of the original dioxide was found unreacted and adhering to the walls of the cell.

When freshly prepared hydroxide precipitates in 1 to $5 \mathrm{M} \mathrm{OH}^{-}$were used as starting material, the dissolution - oxidation electrolysis appeared to be accomplished in 2 to 4 hours; i.e., much more rapidly than in case of the calcined oxides. For instance, $6 \times 10^{-4} \mathrm{M} \mathrm{Am(VI)} \mathrm{solution} \mathrm{in} 5 \mathrm{M} \mathrm{NaOH}$ has been obtained, using Am(III) hydroxide precipitate, by 2.3 hours' electrolysis at a Pt anode with current density $7 \mathrm{~mA} / \mathrm{cm}^{2}$ and S/V ratio $0.5 \mathrm{~cm}^{2} / \mathrm{mL}$ (Peretrukhin et al. 1974).

A $1.5 \times 10^{-3} \mathrm{M} \mathrm{Pu}(\mathrm{VII})$ solution has been prepared using $\mathrm{PuO}_{2} \cdot \mathrm{xH}_{2} \mathrm{O}$ precipitate, with 2.5 hours' electrolysis at the current density $15 \mathrm{~mA} / \mathrm{cm}^{2}$, at $15{ }^{\circ} \mathrm{C}$ and a $\mathrm{S} / \mathrm{V}$ ratio of $0.5 \mathrm{~cm}^{2} / \mathrm{mL}$ (Peretrukhin 1980). The current efficiency of the developed process was found to be about $1 \%$. Temperature increase to $60{ }^{\circ} \mathrm{C}$ was found to increase the rate insignificantly. The mechanism of anodic precipitate dissolution apparently includes the interaction of solid hydroxide particles with $\mathrm{OH}$ radicals and other oxidizing reagents generated at the anode. The reaction of solid hydroxide particles with An(VI) and An(VII) accumulated in the solution during electrolysis also seems to be possible.

When actinide(V),(VI) alkaline solutions or precipitates are used as starting material for electrochemical oxidation, the accumulation of An(VII) in the solution is further accelerated compared to oxidation of the An hydroxide precipitates in the $(+3)$ and $(+4)$ oxidation states. Methods of $\mathrm{Np}(\mathrm{VII})$ and $\mathrm{Pu}(\mathrm{VII})$ solution preparation with anodes fabricated of $\mathrm{Pt}$, $\mathrm{PbO}_{2}$, and other materials have been developed (See Table 4-1).

The values of current efficiency obtained for $\mathrm{Np}$ (VI) electrochemical oxidation appear to be much higher than those of $\mathrm{Pu}(\mathrm{VI})$. Completeness of the reaction in both cases was found to be the same ( 97 to $99 \%$ ). These values are comparable with chemical methods commonly used for actinide(VII) alkaline solutions preparation. Complete (100\%) oxidation of Np and especially $\mathrm{Pu}$ in alkaline solutions seems to be impossible because of their thermodynamic instability and ability to reduce water. 
Table 4-1. Current Density (i) and Current Efficiency (k) for Np(VII) and Pu(VII) Alkaline Solution Preparation Using Different Anodes at $25^{\circ} \mathrm{C}$.

\begin{tabular}{|c|c|c|c|c|c|c|c|c|c|c|}
\hline \multicolumn{11}{|c|}{$\mathbf{N p}(\mathrm{VI})-\mathrm{Np}(\mathrm{VII})$ oxidation } \\
\hline Anode & \multicolumn{2}{|c|}{$\mathrm{Pt}$} & \multicolumn{2}{|c|}{$\mathrm{PbO}_{2}$} & \multicolumn{2}{|c|}{$\mathrm{C}$ (gr.) } & \multicolumn{2}{|c|}{$\mathrm{Ni}$} & \multicolumn{2}{|c|}{ St. steel } \\
\hline $\mathrm{KOH}, \mathrm{M}$ & 1 & 4 & 1 & 4 & 1 & 4 & 1 & 4 & 1 & 4 \\
\hline $\mathrm{i}, \mathrm{mA} / \mathrm{cm}^{2}$ & 6.0 & 5.5 & 7.0 & 6.8 & 9.5 & 9.0 & 7.1 & 6.5 & 13.6 & 43 \\
\hline $\mathrm{K}, \%$ & 94 & 95 & 92 & 90 & 65 & 68 & 85 & 82 & 11.7 & 36 \\
\hline \multicolumn{9}{|c|}{$\mathrm{Pu}(\mathrm{VI})$ - Pu(VII) oxidation } & & \\
\hline Anode & \multicolumn{4}{|c|}{$\mathrm{Pt}$} & \multicolumn{4}{|c|}{$\mathrm{PbO}_{2}$} & & \\
\hline $\mathrm{KOH}, \mathrm{M}$ & 1 & 4 & 6.1 & 12.1 & 1 & 4 & 6.1 & 12.2 & & \\
\hline $\mathrm{i}, \mathrm{mA} / \mathrm{cm}^{2}$ & 150 & 100 & 60 & 20 & 2000 & 320 & 120 & 50 & & \\
\hline $\mathrm{K}, \%$ & 3.5 & 5.3 & 8.8 & 24.1 & 0.2 & 1.6 & 4.4 & 10.6 & & \\
\hline
\end{tabular}

The stability of Np(VII) (Shatokhina and Peretrukhin 1977), Pu(VII) (Komkov et al. 1969), and Am(VI) prepared electrochemically in alkaline solutions as a function of time has been studied. Time of spontaneous half reduction is 10 to $30 \%$ shorter for the electrochemically prepared solution samples as compared to those prepared by ozonolysis. Accelerated self-reduction of $\mathrm{Np}$ (VII) and Pu(VII) in electrochemically prepared alkaline solutions is explained by their contamination with anode corrosion products, since these products catalyze the actinide reduction with water (Krot et al. 1977).

The stabilities of $\mathrm{Np}$ (VII) and $\mathrm{Pu}$ (VII) in alkaline media are significantly reduced in the presence of anode materials ( $\mathrm{Pt}, \mathrm{PbO}_{2}$, graphite) without application of polarization current. The rate of $\mathrm{Pu}$ (VII) and $\mathrm{Am}(\mathrm{VI})$ spontaneous reduction was found to be proportional to the square of area of the electrode material sample introduced to the alkaline solution (Ananiev 1978). The observed electrode material catalytic effect seems to be of electrochemical nature. $\mathrm{Pu}$ (VII) and $\mathrm{Am}$ (VI) create sufficiently high oxidation potentials in the solutions such that oxygen evolution on the surface of the electrode material takes place in the same manner as at the electrode polarized with same potential from an external power source.

Electrochemical preparation of $\mathrm{Np}(\mathrm{V})$ (Simakin and Matyashchuk 1969; and Zielen and Cohen 1970), Pu(V) (Bourges 1972), and Am(V) (Peretrukhin et al. 1974) from An(VII)/An(VI) alkaline solutions may be easily carried out by potentiostatic electrolysis at potentials $200 \mathrm{mV}$ more negative than the value of the corresponding formal potential. Conversely, the back oxidation of $\mathrm{An}(\mathrm{V})$ in alkaline media can occur when applying a polarization potential $200 \mathrm{mV}$ more positive than the corresponding formal potential values (see Section 2.0). 


\subsection{ELECTROCHEMICAL METHODS OF DETERMINATION OF ACTINIDES AND TECHNETIUM IN ALKALINE MEDIA}

A traditional electrodeposition technique with Pt or stainless steel cathodes, followed by $\alpha$-spectrometry, is commonly applied for trace TRU determination. Pu(VI) electrodeposition from 1.6 to $2 \mathrm{M} \mathrm{NaOH}$ solutions was found to occur with $100 \%$ yield at current densities more than $40 \mathrm{~mA} / \mathrm{cm}^{2}$. Complete electrodeposition is achieved in 2 hours (Muller and Brouns 1952). At a current density of $25 \mathrm{~mA} / \mathrm{cm}^{2}$, the layers of electrodeposited $\mathrm{Pu}$ (IV) hydroxide appear to be more uniform, but $90 \% \mathrm{Pu}$ deposition is achieved only in 4 hours (Milyukova et al. 1969). At high $\left(0.4\right.$ to $\left.0.5 \mathrm{~A} / \mathrm{cm}^{2}\right)$ current densities, 98 to $99 \%$ electrodeposition of uranium, trace amounts of thorium-234, plutonium, and cerium-144 may be reached in 40 minutes (Zantuti et al. 1991). Thus, pure $\mathrm{NaOH}$ solutions appear to be convenient electrolytes for actinide electrodeposition.

However, in presence of weighable amounts of other metals susceptible to electrodeposition in these conditions (for instance $\mathrm{CrO}_{4}{ }^{2-}$ ), further $\alpha$-spectrometric actinide determination becomes impossible due to the self-absorption of $\alpha$-particles in the layer.

Weighable amounts of $\mathrm{U}, \mathrm{Np}, \mathrm{Pu}$, and $\mathrm{Am}$ (in oxidation states $+7,+6$ and +5 ) may be determined by a direct voltametric method, because their solubilities in alkaline solutions are sufficiently high. Spectrophotometric methods, widely used for actinide determination in acidic solutions, finds its application in alkaline media only for determination of actinides in the heptavalent $(+7)$ oxidation state. Actinides in lower oxidation states $(+6$ and +5$)$ possess very low molar extinction coefficients and cannot be determined directly.

Therefore, voltammetry remains the primary method for non-destructive measurement of $\mathrm{U}(\mathrm{VI}), \mathrm{Np}(\mathrm{VI}, \mathrm{V}), \mathrm{Pu}(\mathrm{VI}, \mathrm{V})$, and $\mathrm{Am}(\mathrm{VI}, \mathrm{V})$ concentrations in alkaline solutions.

Determination of these elements with a $\mathrm{Pt}$ rotating disc electrode in $\mathrm{NaOH}$ and $\mathrm{LiOH}$ solutions have been described. U(VI) and Pu(VI,V) were shown to be determined in 1 to 4 $\mathrm{M} \mathrm{NaOH}$ solutions with a dropping mercury electrode, using direct current or differential pulse polarography. Np(VII,VI,V) (Peretrukhin and Alekseeva 1975), U(VI), Pu(VI,V) (Bourges 1972; and Abuzwida et al. 1991), Pu(VII) (Peretrukhin 1980), and Am(VI,V) (Peretrukhin et al. 1974) voltametric determination in alkaline solutions is described.

Neptunium determination, using the values of limiting currents of the wave $N p(V I I) / N p(V I)$, appears to be possible in a wide range $(0.2$ to $10 \mathrm{M})$ of $\mathrm{NaOH}$ concentrations. $\mathrm{Np}(\mathrm{VI})$ and $\mathrm{Np}(\mathrm{V})$ determination in 0.1 to $3.5 \mathrm{M} \mathrm{NaOH}$ is complicated due to changes in the $\mathrm{Np}$ ions' chemical states accompanying the electron transfer reaction. Formation of poorly soluble $\mathrm{Np}(\mathrm{V})$ hydroxide and its adsorption on the electrode surface disturbs the results of quantitative determination. In this range of alkali concentrations in supporting electrolyte and in 0.1 to $1.9 \mathrm{M} \mathrm{LiOH}$, the limiting current of the wave $\mathrm{Np}(\mathrm{VI}) / \mathrm{Np}(\mathrm{V})$ is determined not only by the concentration of $\mathrm{Np}$ in the sample but also is affected by alkali concentration (Peretrukhin and Alekseeva 1975). In more concentrated alkaline solutions (with greater than $4 \mathrm{M} \mathrm{NaOH}$ or $2 \mathrm{M} \mathrm{LiOH})$, all the chemical species of $\mathrm{Np}(\mathrm{V})$ present in the solution appear 
to be electroactive. The limiting currents of $\mathrm{An}(\mathrm{VI}) / \mathrm{An}(\mathrm{V})(\mathrm{An}=\mathrm{U}, \mathrm{Np}, \mathrm{Pu}, \mathrm{Am})$ reactions in solution are not affected by moderate changes in alkali concentration (e.g., $4.0 \pm 0.25 \mathrm{M} \mathrm{NaOH}$ ).

Direct current voltametry may be applied not only to solutions containing the element of interest in a given oxidation state [(Np(VII), $\mathrm{Np}(\mathrm{VI})$ or $\mathrm{Np}(\mathrm{V}))$ ], but also allows determination of concentration ratios between several oxidation states. For neptunium in the concentration range of $5 \times 10^{-5}$ to $4 \times 10^{-3} \mathrm{M}$, the method results in 3 to $5 \%$ experimental error regardless of the neptunium oxidation state in solution. Nitrate, sulfate, and uranyl do not interfere. In the presence of $\mathrm{Pu}(\mathrm{VI})$ and $\mathrm{Pu}(\mathrm{V})$, the determination of $\mathrm{Np}$ in alkaline media becomes more complicated (Peretrukhin and Alekseeva 1975).

Simultaneous determination of $\mathrm{U}(\mathrm{VI}), \mathrm{Pu}(\mathrm{VI})$, and $\mathrm{Pu}(\mathrm{V})$ in alkaline media has been elaborated by means of direct current and differential pulse polarography (Abuzwida et al. 1991). In 1 to $4 \mathrm{M} \mathrm{NaOH}, \mathrm{U}(\mathrm{VI})$ is reduced at a dropping mercury electrode to $\mathrm{U}(\mathrm{V})$ at a half-wave potential $\left(\mathrm{E}_{1 / 2}\right)$ of $-0.89 \mathrm{~V}$ vs. $\mathrm{Ag} / \mathrm{AgCl}$ (See Figure 4-1). The limiting current of this wave was found to be proportional to U(VI) concentration in $4 \mathrm{M}$ $\mathrm{NaOH}$ in the range $1.3 \times 10^{-7}$ to $3 \times 10^{-4} \mathrm{M}$. At higher uranium concentrations, deviations from linearity are observed due to polymerization of uranates. $\mathrm{Pu}(\mathrm{VI})$ and $\mathrm{Pu}(\mathrm{V})$ may be determined with a $\mathrm{Pt}$ microelectrode at an $\mathrm{E}_{/ 2}$ of $+0.02 \mathrm{~V}$ vs. $\mathrm{Ag} / \mathrm{AgCl}$ and with a dropping mercury electrode at $-1.1 \mathrm{~V}$ vs. $\mathrm{Ag} / \mathrm{AgCl}$. The limiting currents of both plutonium reduction waves are found to be proportional to $\mathrm{Pu}$ concentration in the range $4 \times 10^{-6}$ to $1.2 \times 10^{-3} \mathrm{M}$. The determination of $\mathrm{U}(\mathrm{VI}), \mathrm{Pu}(\mathrm{VI})$, and $\mathrm{Pu}(\mathrm{V})$ are not affected by the presence of $2 \mathrm{M} \mathrm{NaNO}_{3}, 2 \mathrm{M} \mathrm{NaNO}_{2}, 1.5 \mathrm{M} \mathrm{NaAlO}_{2}, 0.5 \mathrm{M} \mathrm{NaF}$, and ions such as $\mathrm{Mo}(\mathrm{VI}), \mathrm{W}(\mathrm{VI}), \mathrm{V}(\mathrm{V})$, and $\mathrm{Cu}(\mathrm{II})$. The presence of $\mathrm{CrO}_{4}{ }^{2-}$ and $\mathrm{FeO}_{2}$ disturbs the determination of $\mathrm{U}(\mathrm{VI})$ and $\mathrm{Pu}(\mathrm{V})$. The contribution of the reaction $\mathrm{Fe}(\mathrm{III}) / \mathrm{Fe}(\mathrm{II})$ to the limiting current of uranium reduction may, however, be calculated from the height of the second iron reduction wave, $\mathrm{Fe}(\mathrm{II}) / \mathrm{Fe}^{\circ}$.

Voltammetric methods have also been elaborated for determining the ratio of actinide $[\mathrm{Np}(\mathrm{VI})+\mathrm{Np}(\mathrm{V}) ; \mathrm{Np}(\mathrm{VII})+\mathrm{Np}(\mathrm{VI}) ; \mathrm{Pu}(\mathrm{V})+\mathrm{Pu}(\mathrm{VI}) ; \mathrm{Pu}(\mathrm{VII})+\mathrm{Pu}(\mathrm{VI})]$ concentrations present in alkaline solutions in different oxidation states (Peretrukhin 1980). 
Figure 4-1. Voltametry of $\mathrm{U}(\mathrm{VI}), \mathrm{Pu}(\mathrm{VI})$ and $\mathrm{Pu}(\mathrm{V})$ in $1 \mathrm{M} \mathrm{NaOH}$.

Curves: 1a $-1 \times 10^{-4} \mathrm{M} \mathrm{U}(\mathrm{VI}), \mathrm{DC}$ polarogram at DME, process $\mathrm{U}(\mathrm{VI})+\mathrm{e}^{-} \rightarrow \mathrm{U}(\mathrm{V})$, $1 b$ - difference pulse polarography at DME,

$2 \mathrm{a}-1.2 \times 10^{-4} \mathrm{M} \mathrm{Pu}(\mathrm{VI}), \mathrm{DC}$ voltametry at Pt electrode, process $\mathrm{Pu}(\mathrm{VI})+\mathrm{e}^{-} \rightarrow \mathrm{Pu}(\mathrm{V})$, $2 \mathrm{~b}$ - DC polarogram at DME,

$\mathrm{i}_{1}$ corresponds to process $\mathrm{Pu}(\mathrm{VI})+\mathrm{e}^{-} \rightarrow \mathrm{Pu}(\mathrm{V})$,

$\mathrm{i}_{2}-\mathrm{Pu}(\mathrm{V})+\mathrm{e}^{-} \rightarrow \mathrm{Pu}(\mathrm{IV})$,

$\mathrm{i}_{3}-\mathrm{Pu}(\mathrm{IV})+\mathrm{e}^{-} \rightarrow \mathrm{Pu}(\mathrm{III})$,

$3 \mathrm{a}-1.2 \times 10^{-4} \mathrm{M} \mathrm{Pu}(\mathrm{V}), \mathrm{DC}$ voltametry at $\mathrm{Pt}$ electrode, process $\mathrm{Pu}(\mathrm{V})+\mathrm{e}^{-} \rightarrow \mathrm{Pu}(\mathrm{VI})$, $3 \mathrm{~b}-\mathrm{DC}$ polarogram at DME, process $\mathrm{Pu}(\mathrm{V})+2 \mathrm{e}^{-} \rightarrow \mathrm{Pu}(\mathrm{III})$.

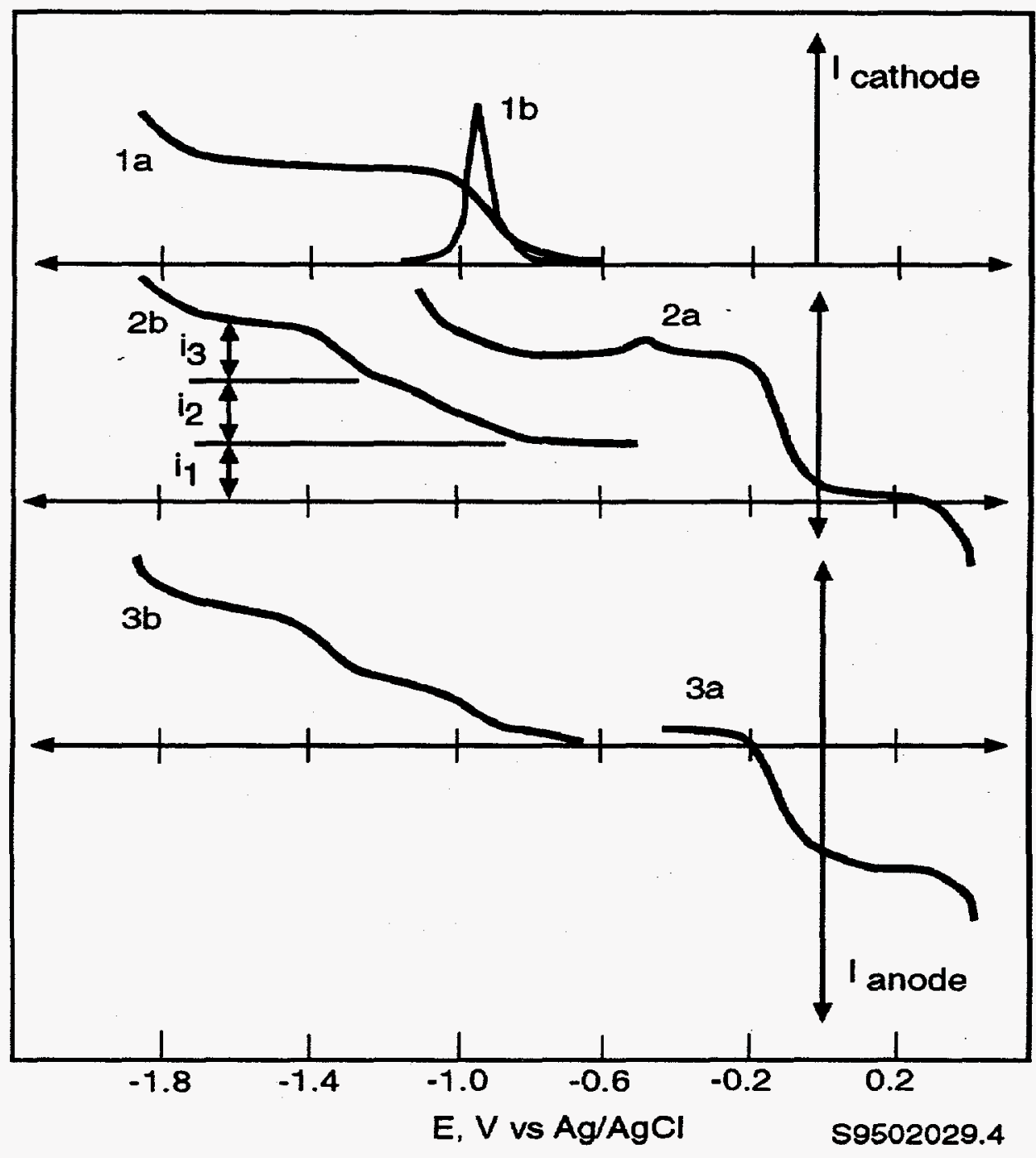




\subsection{REFERENCES}

Abuzwida, M. A., A. G. Maslennikov, and V. F. Peretrukhin, 1991, Radioanal. Nucl. Chem. Articles, 147, No. 1, p. 141.

Ananiev, A. V., E. A. Soldatov, and V. F. Peretrukhin, 1978, Dokl. Akad. Nauk SSSR, 241 , No. 3, p. 602 .

Bourges, J., 1972, Radiochem. Radioanal. Lett., 12, No. 2-3, p. 111.

Cook, G. P., J. K. Foreman, and E. F. Kemp, 1958, Anal. Chim. Acta, 19, No. 2, p. 174.

Founta, A., D. A. Aikens, and H. M. Clark, 1987, J. Electroanal. Chem., $\underline{219}$, p. 221.

Komkov, Yu. A., V. F. Peretrukhin, N. N. Krot, and A. D. Gel'man, 1969, Radiokhimiya, 11 , No. 4, p. 407.

Krot, N. N., A. D. Gel'man, M. P. Mefod'eva, V. P. Shilov, V. F. Peretrukhin, and V. I. Spitsyn, 1977, Semivalentnoe Sostayanie Neptuniya, Plutoniya, Ameritsiya, Nauka Publ., Moscow, USSR (in Russian). Available in English as Heptavalent State of Neptunium, Plutonium and Americium, UCRL-Trans-11798, Lawrence Livermore National Laboratory, Livermore, California.

Milyukova, M. S., N. I. Gusev, I. G. Sentyurin, and I. S. Sklyarenko, 1969, "Electrodeposition of Pu from Solutions," in: Analytical Chemistry of Plutonium, Ann Arbor - Humphrey Sci. Publ., London, UK, p. 120.

Muller, H. W., and R. J. Brouns, 1952, Anal.Chem., 24, p. 536.

Peretrukhin, V. F., 1980, Electrochemical and Nuclear Chemical Reactions of Actinides in Solutions at High Oxidation and Reduction Potentials, Thesis for Professor Degree, Institute of Physical Chemistry, Academy of Sciences USSR, Moscow, USSR (in Russian).

Peretrukhin, V. F., and D. P. Alekseeva, 1975, Radiokhimiya, 30, No. 6, p. 1127.

Peretrukhin, V. F., and D. P. Alekseeva, 1974a, Radiokhimiya, 16, No. 6, p. 836.

Peretrukhin, V. F., and D. P. Alekseeva, 1974b, Radiokhimiya, 16, No. 6, p. 843.

Peretrukhin, V. F., V. B. Nikolayevsky, and V. P. Shilov, 1974, Radiokhimiya, 16, No. 6, p. 833.

Shatokhina, O. B., and V. F. Peretrukhin, 1977, Radiokhimiya, 19, No. 6, p. 819. 
Shvedov, V. P., and V. I. Seregin, 1972, Radiokhimiya, 14, No. 4, p. 626.

Simakin, G. A., and I. V. Matyashchuk, 1969, Radiokhimiya, 11, No. 4, p. 481.

Zantuti, F., B. Al-Medehem, V. I. Silin, and V. F. Peretrukhin, 1991, Radioanal. Nucl. Chem. Articles, 147, No. 1, p. 51.

Zielen, A. J., and D. Cohen, 1970, J. Phys. Chem., 74, No. 2, pp. 394-405.

Zhdanov, S. I., A. F. Kuzina, and V. I. Spitsyn, 1970, Zh. Neorg. Khim., 15, p. 803. 
This page intentionally left blank. 


\subsection{RADIATION CHEMISTRY OF ACTINIDES AND TECHNETIUM IN CARBONATE AND ALKALINE SOLUTIONS}

Highly radioactive aqueous solutions, including carbonate and alkaline solutions, are produced upon reprocessing of spent nuclear fuel and upon the separation of practically important radionuclides. The products of water radiolysis appear in the solutions as a result of the action of $\alpha$-, $\beta$ - and $\gamma$-radiations of actinides, cesium, strontium, rare earths, and other elements. Radiolysis products include short lived (hydrated electron, $\mathrm{H}$ atom, $\mathrm{OH}$, and $\mathrm{HO}_{2}$ radicals) and long lived species $\left(\mathrm{H}_{2}\right.$ and $\left.\mathrm{H}_{2} \mathrm{O}_{2}\right)$. Table 5-1 shows the yields (G values) of primary products of water radiolysis measured as a number of ions, molecules, or atoms per $100 \mathrm{eV}$ of absorbed energy of ionizing radiation.

Table 5-1. The Yields of Primary Products of Water Radiolysis in Bulk Solution for ${ }^{60} \mathrm{Co}$ $\gamma$-Rays and Fast Electrons with Energies of $1 \mathrm{MeV}$ and Higher (Pikaev 1986).

\begin{tabular}{|c|c|c|c|c|c|c|c|c|}
\hline $\mathrm{pH}$ & $\mathrm{G}_{\mathrm{e}_{\mathrm{s}}^{-}}$ & $\mathrm{G}_{\mathrm{H}}$ & $\mathrm{G}_{\mathrm{OH}}$ & $\mathrm{G}_{\mathrm{O}}$ & $\mathrm{G}_{\mathrm{H}_{2}}$ & $\mathrm{G}_{\mathrm{H}_{2} \mathrm{O}_{2}}$ & $\mathrm{G}_{\mathrm{H}_{\mathrm{m}}^{*}}$ & $\mathrm{G}_{\mathrm{OH}_{\mathrm{s}}^{-}}$ \\
\hline $0-2$ & 3.05 & 0.6 & 2.95 & 0.0067 & 0.45 & 0.8 & - & - \\
\hline $4-9$ & $2.8-2.9$ & 0.6 & $2.8-2.9$ & 0.0067 & 0.45 & 0.75 & $3.3-3.4$ & $0.5-0.6$ \\
\hline $12-13$ & $2.8-2.9$ & 0.55 & 2.9 & 0.012 & 0.4 & 0.75 & - & - \\
\hline
\end{tabular}

$\alpha$-Particles emitted by actinides have an energy of 5 to $6 \mathrm{MeV}$. The yields of water radiolysis products for such $\alpha$-particles were not determined. However, the yields in $0.4 \mathrm{M}$ $\mathrm{H}_{2} \mathrm{SO}_{4}$ were measured in the case of ${ }^{210} \mathrm{Po} \alpha$-particles (see Table 5-2) (Vladimirova 1968).

Table 5-2. The Yields of Primary Products of Water Radiolysis for $\alpha$-Particles.

\begin{tabular}{|c|c|c|c|c|c|c|c|}
\hline $\begin{array}{c}\text { Energy, } \\
\mathrm{MeV}\end{array}$ & Medium & $\mathrm{G}_{\mathrm{c}_{\text {i }}}+\mathrm{G}_{\mathrm{H}}$ & $\mathrm{G}_{\mathrm{OH}}$ & $\mathrm{G}_{\mathrm{H}_{2}}$ & $\mathrm{G}_{\mathrm{H}_{2} \mathrm{O}_{2}}$ & $\mathrm{G}_{\mathrm{HO}_{2}}$ & References \\
\hline 5.3 & $\begin{array}{c}0.4 \mathrm{M} \\
\mathrm{H}_{2} \mathrm{SO}_{4}\end{array}$ & 0.55 & 0.35 & 1.4 & 1.3 & 0.2 & {$[1]$} \\
\hline 6.4 & $\mathrm{pH} 7$ & - & 0.4 & - & 0.95 & 0.085 & {$[2]$} \\
\hline
\end{tabular}

${ }^{2}$ References:

[1] Vladimirova 1968

[2] Burns and Sims 1981 
Because their energy is $5.3 \mathrm{MeV}$, the results of these measurements can be used for the interpretation of experimental data on radiolytic conversions in aqueous solutions upon the action of $\alpha$-radiation. Table 5-2 contains also the yields for $\alpha$-particles (helions) with energy 6.4 MeV in neutral solution (Burns and Sims 1981).

The hydrated electron is a powerful reducing agent. The standard redox potential $\left(\mathrm{E}^{\circ}\right)$ for reaction

$$
\begin{gathered}
\mathrm{e}_{\mathrm{aq}}^{-} \rightleftarrows \mathrm{e}^{-}+\mathrm{H}_{2} \mathrm{O} \\
\mathrm{H}_{\mathrm{aq}}^{+}+\mathrm{e}^{-} \rightleftarrows \frac{1}{2} \mathrm{H}_{2} \text { (gas) }
\end{gathered}
$$

or

$$
\mathrm{e}_{\mathrm{aq}}^{-}+\mathrm{H}^{+} \rightleftarrows \frac{1}{2} \mathrm{H}_{2} \text { (gas) }
$$

is $-2.87 \mathrm{~V}$ (Pikaev 1986). In the electromotive series, it is located between Na and La. The reactions of $\mathrm{e}_{\mathrm{aq}}^{-}$are divided into three groups: (1) addition to ions (reduction), (2) addition to neutral molecules, and (3) dissociative addition.

Reduced ions in lower and often unusual oxidation states are formed in reactions of the first group. The process

$$
\mathrm{e}_{\mathrm{aq}}^{-}+\mathrm{O}_{2} \rightarrow \mathrm{O}_{2}^{-}
$$

is an example of reactions of the second group. The product radical ion is the alkaline form of the $\mathrm{HO}_{2}$ radical. The third group involves reactions leading to the formation of radicals:

$$
\begin{gathered}
\mathrm{e}_{\mathrm{aq}}^{-}+\mathrm{S}_{2} \mathrm{O}_{8}^{2-} \rightarrow \mathrm{SO}_{4}^{-}+\mathrm{SO}_{4}^{2-} \\
\mathrm{e}_{\mathrm{aq}}^{-}+\mathrm{N}_{2} \mathrm{O} \rightarrow \mathrm{N}_{2}+\mathrm{O}^{-}
\end{gathered}
$$

In the radiation chemistry of aqueous systems, reaction (6) may be used to produce the radical ion $\mathrm{O}^{-}$(in alkaline medium) or the radical $\mathrm{OH}$ (in neutral and acid media) from $\mathrm{e}_{\mathrm{aq}}^{-}$. 
Other reactions in which $\mathrm{e}_{\mathrm{aq}}^{-}$can be converted to the hydroxyl radical are:

$$
\begin{aligned}
& \mathrm{H}_{2} \mathrm{O}_{2}+\mathrm{e}_{\mathrm{aq}}^{-} \rightarrow \mathrm{OH}+\mathrm{OH}^{-} \\
& \mathrm{ClO}^{-}+\mathrm{e}_{\mathrm{aq}}^{-} \rightarrow \mathrm{O}^{-}+\mathrm{Cl}^{-} \\
& \mathrm{BrO}^{-}+\mathrm{e}_{\mathrm{aq}}^{-} \rightarrow \mathrm{O}^{-}+\mathrm{Br}^{-}
\end{aligned}
$$

The $\mathrm{H}$ atom is a weaker reducing agent than $\mathrm{e}_{\mathrm{aq}}^{-}$. The $\mathrm{E}^{\circ}$ value for $\mathrm{H}$ is $-2.3 \mathrm{~V}$ (Pikaev 1986). This species plays an important role in an acid medium. In alkaline media, it is converted to $\mathrm{e}_{\mathrm{aq}}^{-}$:

$$
\mathrm{H}+\mathrm{OH}^{-} \rightleftarrows \mathrm{e}_{\mathrm{aq}}^{-}+\mathrm{H}_{2} \mathrm{O}
$$

Reaction (10) is reversible: $\mathrm{pK}_{10}$ equals 9.6 (Pikaev 1986).

As a rule, the $\mathrm{H}$ atom reacts with inorganic compounds more slowly than does $\mathrm{e}_{\mathrm{aq}}^{-}$Molecular oxygen and the $\mathrm{OH}$ radical are the exceptions; the rates of their reactions with $\mathrm{e}_{\mathrm{aq}}^{-}$ and $\mathrm{H}$ are approximately the same.

The radical $\mathrm{OH}$ is a strong oxidizing agent. The $\mathrm{E}^{\circ}$ value is $1.9 \mathrm{~V}$ (Pikaev 1986). Its reactions with inorganic compounds can be divided into two main groups: (1) simple oxidation and (2) abstraction of $\mathrm{H}$ from hydrogen-containing compounds.

In alkaline media, the $\mathrm{OH}$ radical dissociates:

$$
\mathrm{OH}+\mathrm{OH}^{-} \rightleftarrows \mathrm{O}^{-}+\mathrm{H}_{2} \mathrm{O}
$$

The $\mathrm{pK}_{11}$ value is 11.9 (Pikaev 1986).

The radical ion $\mathrm{O}^{-}$reacts with inorganic compounds generally more slowly than does $\mathrm{OH}$. However, in contrast to $\mathrm{OH}$, this radical ion reacts rapidly with oxygen:

$$
\mathrm{O}^{-}+\mathrm{O}_{2} \rightarrow \mathrm{O}_{3}^{-}
$$

The product ozonide ion $\mathrm{O}_{3}^{-}$is an oxidizing agent. 
The radical $\mathrm{HO}_{2}$ and its alkaline form $\mathrm{O}_{2}^{-}$play important roles upon radiolysis of aqueous solutions containing oxygen. The potentials of the pairs $\mathrm{O}_{2} / \mathrm{HO}_{2}$ and $\mathrm{O}_{2} / \mathrm{O}_{2}^{-}$are -0.3 and $-0.56 \mathrm{~V}$, respectively (Pikaev 1986).

Hydrogen peroxide, $\mathrm{H}_{2} \mathrm{O}_{2}$, depending on the nature of the solute and the $\mathrm{pH}$ value of the solution, can act as both an oxidizing and a reducing agent. In alkaline media, hydrogen peroxide exists in an ionic form:

$$
\mathrm{H}_{2} \mathrm{O}_{2}+\mathrm{OH}^{-} \rightleftarrows \mathrm{HO}_{2}^{-}+\mathrm{H}_{2} \mathrm{O}
$$

The $\mathrm{pK}_{13}$ value is 11.9 (Pikaev 1986).

As a rule, molecular hydrogen does not take part in reactions with solutes.

\subsection{REACTIVITY OF ACTINIDE IONS TOWARDS WATER RADIOLYSIS PRODUCTS AND OTHER FREE RADICALS}

Much is known on the reactivity of actinide ions towards water radiolysis products and other free radicals in aqueous solutions. The respective data for carbonate and alkaline media are considered in this section.

\subsubsection{Carbonate Medium}

The main radical products of the radiolysis of carbonate solutions are $\mathrm{e}_{\mathrm{aq}}^{-}$and the radical ion, $\mathrm{CO}_{3}^{-}$(Zhestkova and Pikaev 1976). The reactions of these species with ions of actinides in higher oxidation states were studied thoroughly (Pikaev et al. 1974; Mulac et al. 1984; Gogolev 1990). The rate constants of $\mathrm{e}_{\mathrm{aq}}^{-}$reactions with ions of uranium, neptunium, and plutonium, measured by the pulse radiolysis methods, are listed in Table 5-3.

From the table it follows that the rate constants for $\mathrm{Np}(\mathrm{VI})$ depend slightly on $\mathrm{CO}_{3}^{2-}$ concentration. A conclusion was made that the limiting step of the reactions is the diffusion of reacting species (Pikaev et al. 1974). It was also suggested that the structure of $\mathrm{NpO}_{2}\left(\mathrm{CO}_{3}\right)_{3}^{4}$ is not changed within the range of $\mathrm{CO}_{3}^{2-}$ concentrations studied; because of it, the change in $\mathrm{K}_{2} \mathrm{CO}_{3}$ or $\mathrm{Na}_{2} \mathrm{CO}_{3}$ concentration has an effect owing to the change in the viscosity of the medium. 
Table 5-3. Rate Constants (k) of $\mathrm{e}_{\mathrm{aq}}^{-}$Reactions with Actinide Ions in Carbonate Solutions.

\begin{tabular}{|c|c|c|c|c|c|}
\hline Ion & $\begin{array}{c}\text { [Ion] } \times 10^{5}, \\
\mathrm{M}\end{array}$ & $\begin{array}{c}{\left[\mathrm{K}_{2} \mathrm{CO}_{3}\right]} \\
\mathrm{M}\end{array}$ & $\begin{array}{c}\mathrm{E}_{f}, \mathrm{~V} \\
(\mathrm{NHE})^{\mathrm{c}}\end{array}$ & $\begin{array}{l}\mathrm{k} \times 10^{-9}, \\
\mathrm{M}^{-1} \mathrm{~s}^{-1}\end{array}$ & Reference $^{\mathrm{d}}$ \\
\hline $\mathrm{U}(\mathrm{VI})$ & - & $0.05^{a}$ & -0.671 & 11.8 & [1] \\
\hline \multirow[t]{7}{*}{$\mathrm{Np}(\mathrm{VI})$} & - & $0.05^{a}$ & 0.445 & 23.4 & [1] \\
\hline & 2.7 & $\bar{b}$ & - & 19 & [2] \\
\hline & 5.4 & & - & 17 & [2] \\
\hline & 5.4 & 0.1 & - & 19 & [2] \\
\hline & 2.7 & 1.0 & - & 13 & [2] \\
\hline & 5.4 & 1.0 & - & 11 & [2] \\
\hline & 5.4 & 5.0 & - & 6.2 & [2] \\
\hline \multirow[t]{3}{*}{$\mathrm{Np}(\mathrm{V})$} & 20 & 0.1 & - & 2.5 & [2] \\
\hline & 20 & 1.0 & - & 2.0 & [2] \\
\hline & 20 & 5.0 & - & 1.9 & [2] \\
\hline \multirow[t]{6}{*}{$\mathrm{Np}(\mathrm{IV})$} & 5.0 & 0.1 & - & 5.0 & [2] \\
\hline & 5.0 & 1.0 & - & 4.0 & [2] \\
\hline & 6.7 & 1.0 & - & 4.0 & [2] \\
\hline & 6.7 & 4.3 & - & 4.0 & [2] \\
\hline & 5.0 & 4.5 & - & 3.7 & [2] \\
\hline & - & 6.0 & - & 3.0 & [3] \\
\hline \multirow[t]{4}{*}{$\mathrm{Pu}(\mathrm{VI})$} & - & $0.05^{\mathrm{a}}$ & 0.334 & 22.8 & [1] \\
\hline & - & 0.1 & - & 23 & [2] \\
\hline & - & 1.0 & - & 14 & [2] \\
\hline & - & 5.0 & - & 6 & [2] \\
\hline
\end{tabular}

${ }^{2} \mathrm{Na}_{2} \mathrm{CO}_{3}$

${ }^{b} 0.5 \mathrm{M} \mathrm{NaHCO} 3+0.5 \mathrm{M} \mathrm{Na}_{2} \mathrm{CO}_{3}$

'NHE; normal hydrogen electrode

'References:

[1] Mulac et al. 1984

[2] Pikaev et al. 1974

[3] Gogolev et al. 1990 
The reaction rate constant decreases by approximately one order of magnitude upon the transition from $\mathrm{Np}(\mathrm{VI})$ to $\mathrm{Np}(\mathrm{V})$. In the opinion of the authors of paper

(Pikaev et al. 1974), this feature is connected with the fact that the transition from $\mathrm{Np}(\mathrm{V})$ to $\mathrm{Np}(\mathrm{IV})$ is accompanied by a considerable change in the structure. The influence of $\mathrm{CO}_{3}^{2-}$ concentration on the reaction rate in the case of $\mathrm{Np}(\mathrm{V})$ is also not strong. The limiting factor again is diffusion (Pikaev et al. 1974). The form of the $\mathrm{Np}(\mathrm{V})$ [it seems to be $\mathrm{NpO}_{2}\left(\mathrm{CO}_{3}\right)_{2}^{3-}$ ] is unchanged within the studied range of $\mathrm{CO}_{3}^{2-}$ concentration.

Reaction

$$
\mathrm{Np}(\mathrm{IV})+\mathrm{e}_{\mathrm{aq}}^{-} \rightarrow \mathrm{Np}(\mathrm{III})
$$

occurs faster than the reaction between $\mathrm{Np}(\mathrm{V})$ and $\mathrm{e}_{\mathrm{aq}}^{-}$but slightly slower than the reaction of $\mathrm{e}_{\mathrm{aq}}^{-}$with $\mathrm{Np}$ (VI). It is explained by the fact that the transition of $\mathrm{Np}$ (IV) to $\mathrm{Np}$ (III) has a monoelectron mechanism without the change in the structure of ions as in the case of Np(VI) (Pikaev et al. 1974).

The calculation of $\mathrm{k}_{\mathrm{dif}}$ for reactions of $\mathrm{e}_{\mathrm{aq}}^{-}$with $\mathrm{Np}(\mathrm{VI}), \mathrm{Np}(\mathrm{V})$, and $\mathrm{Np}(\mathrm{IV})$ in carbonate media was described (Pikaev et al. 1975). Although the radii of carbonate complexes are unknown, the authors of the paper evaluated them on the basis of the known crystallographic radii of $\mathrm{Np}^{4+}$ and $\mathrm{NpO}_{2}^{2+}$ and the bond lengths in similar complexes. The respective values of radii $\left(\mathrm{r}_{\mathrm{x}}\right)$ are shown in Table 5-4.

Table 5-4. The Evaluation of $\mathrm{k}_{\mathrm{o}}$ and $\mathrm{k}_{\mathrm{dif}}$ for Reactions of Carbonate Complexes of Neptunium with $\mathrm{e}_{\mathrm{aq}}^{-}$(Pikaev et al. 1975).

\begin{tabular}{|c|c|c|c|c|}
\hline Ion & $\mathrm{k}_{\mathrm{o}}, \mathrm{M}^{-1} \mathrm{~s}^{-1}$ & $\mathrm{r}_{\mathrm{X}}, \AA$ & $\begin{array}{c}\mathrm{D}_{\mathrm{x}} \times 10^{5}, \\
\mathrm{~cm}^{2} \mathrm{~s}^{-1}\end{array}$ & $\mathrm{k}_{\mathrm{dif}}, \mathrm{M}^{-1} \mathrm{~s}^{-1}$ \\
\hline $\mathrm{NpO}_{2}\left(\mathrm{CO}_{3}\right)_{3}^{4}$ & $2.1 \times 10^{9}$ & 3.5 & 0.8 & $1.1 \times 10^{9}$ \\
\hline $\mathrm{NpO}_{2}\left(\mathrm{CO}_{3}\right)_{2}^{3-}$ & $4.5 \times 10^{8}$ & 3.5 & 0.9 & $2.7 \times 10^{9}$ \\
\hline $\mathrm{Np}\left(\mathrm{CO}_{3}\right)_{5}^{6-}$ & $1.3 \times 10^{8}$ & 3.0 & 0.9 & $8.3 \times 10^{7}$ \\
\hline
\end{tabular}

Because the rate constants were measured at comparatively high carbonate concentrations, the values of the constants should be specified because of the salt effect. It was taken into account by the Brönsted-Bjerrum equation:

$$
\log \left(\mathrm{k} / \mathrm{k}_{\mathrm{o}}\right)=-1.02 \mathrm{Z}_{\mathrm{X}} \mu^{1 / 2} /\left(1+\mathrm{a} \mu^{1 / 2}\right)
$$


where $\mathrm{k}$ is the rate constant at the selected ionic strength $\mu, \mathrm{k}_{\mathrm{o}}$ is the rate constant at $\mu=0$, $Z_{X}$ is the charge of ion $X$ reacting with $e_{a q}^{-}$, and $a=r / 3$ ( $r$ is the sum of the $e_{\mathrm{aq}}^{-}$and $X$ radii, in $\AA$ ).

The constants for bimolecular reactions with a diffusion-controlled rate, $\mathrm{k}_{\mathrm{dif}}$, were calculated by means of the Debye equation:

$$
k_{\text {dif }}=4 \pi N\left(r_{e}+r_{X}\right)\left(D_{e}+D_{X}\right) Q /\left[1000\left(e^{Q_{-}}-1\right)\right]
$$

where $\mathrm{N}$ is the Avogadro constant, $r_{e}(2.5 \AA)$ and $r_{X}$ are the $e_{a q}^{-}$and ion $X$ radii, $D_{e}$ and $D_{X}$ are the diffusion coefficients of $e_{\mathrm{aq}}^{-}\left(4.96 \times 10^{-5} \mathrm{~cm}^{2} \mathrm{~s}^{-1}\right)$ and $X, Q=-Z_{X} e^{2} /\left[\epsilon \mathrm{KT}\left(r_{e}+r_{X}\right)\right]$, $Z_{X}$ and $e$ are the charges of $X$ and the electron, $k$ is the Boltzmann constant, $\epsilon$ is the dielectric constant of the medium, and $\mathrm{T}$ is temperature, in $\mathrm{K}$.

The constants $k_{o}$ and $k_{\text {dif }}$ are shown in Table 5-4. On the basis of the data of Table 5-4, it is possible to conclude that the rate of reaction between $\mathrm{e}_{\mathrm{aq}}^{-}$and $\mathrm{NpO}_{2}\left(\mathrm{CO}_{3}\right)_{3}^{4}$ is limited by diffusion. The value of $\mathrm{k}_{\mathrm{o}}$ for $\mathrm{NpO}_{2}\left(\mathrm{CO}_{3}\right)_{2}^{3-}$ is less than $\mathrm{k}_{\text {dif }}$ because of the change in the structure as a result of the reaction.

Note that the ions under consideration can form ionic pairs with counterions. Because of this, the ions' charges can be less negative than shown in Table 5-4. However, this effect does not influence the conclusions made. For example, if the charge of the Np(VI) ion is -3 or -2 , the $\mathrm{k}_{\mathrm{o}}$ and $\mathrm{k}_{\mathrm{dif}}$ values are $3.6 \times 10^{9}$ or $6.6 \times 10^{9} \mathrm{M}^{-1} \mathrm{~s}^{-1}$ and $2.6 \times 10^{9}$ or $6.2 \times 10^{9} \mathrm{M}^{-1} \mathrm{~s}^{-1}$, respectively.

The evaluation of rate constants for reactions of $e_{\mathrm{aq}}^{-}$with $\mathrm{Pu}(\mathrm{III})$ and $\mathrm{Am}$ (III) was carried out (Gogolev et al. 1990). Their possible values are less than $10^{6} \mathrm{M}^{-1} \mathrm{~s}^{-1}$.

The rate constants of reactions of $\mathrm{CO}_{3}^{-}$with uranium, neptunium, and plutonium ions are listed in Table 5-5. The rate constants of reactions of $\mathrm{Ce}$ (III) with $\mathrm{CO}_{3}^{-}$are shown for comparison.

The rate constants depend strongly on the free energy of the reaction (difference of redox potentials) of the reacting species. The linear dependence between $\log k$ and $E_{f}(V I / V)$ was established for uranium, neptunium, and plutonium. The values of constants are discussed on the basis of the Marcus theory for electron transfer. The linear dependence proposes that the inner sphere interaction, i.e. the oxidation of $\mathrm{M}(\mathrm{V})$ by $\mathrm{CO}_{3}^{-}$, occurs via electron transfer.

The dependence of $\log \mathrm{k}$ on $\mathrm{E}_{\mathrm{f}}$ is approximately linear for complex ions of $\mathrm{Am}$ (III), $\mathrm{Pu}$ (III), and $\mathrm{Ce}$ (III) (Gogolev et al. 1990). However, in the case of $\mathrm{Np}(\mathrm{III})$, the $\mathrm{k}$ value does not have this dependence. Obviously, the rate of the reaction of $\mathrm{Np}$ (III) with $\mathrm{CO}_{3}^{-}$is controlled by diffusion. The literature data allow evaluation of the diffusion limit (using the Debye equation) for the rate of the reaction of $\mathrm{Np}(\mathrm{III})$ with $\mathrm{CO}_{3}^{-}$. The calculation gives $\mathrm{k}_{\mathrm{dif}}=4.5 \times 10^{9} \mathrm{M}^{-1} \mathrm{~s}^{-1}$ at $\mu=0$. 
In $1 \mathrm{M}$ solution, the constant can decrease owing to increasing viscosity; however, this decrease is offset by the ionic strength effect.

Table 5-5. The Rate Constants of Reactions of $\mathrm{CO}_{3}^{-}$with Actinide Ions

\begin{tabular}{|c|c|c|c|c|c|c|}
\hline Ion & Medium & {$\left[\mathrm{CO}_{3}^{2-}\right], \mathrm{M}$} & Pair & $E_{f}, V(N C E)$ & $\begin{array}{c}\mathrm{k} \times 10^{-7} \\
\mathrm{M}^{-1} \mathrm{~s}^{-1}\end{array}$ & Reference $^{\mathrm{a}}$ \\
\hline $\mathrm{U}(\mathrm{V})$ & $\mathrm{Na}_{2} \mathrm{CO}_{3}$ & 0.05 & $\mathrm{VI} / \mathrm{V}$ & $-0.671[1]$ & 48.8 & [1] \\
\hline $\mathrm{U}(\mathrm{IV})$ & $\mathrm{KHCO}_{3}$ & -3 & V/IV & $0.0 \quad[2]$ & 1.4 & [3] \\
\hline $\mathbf{N p}(\mathbf{V})$ & $\mathrm{Na}_{2} \mathrm{CO}_{3}$ & 0.05 & $\mathrm{VI} / \mathrm{V}$ & $0.445[1]$ & 1.52 & [1] \\
\hline $\mathrm{Np}$ (III) & $\mathrm{K}_{2} \mathrm{CO}_{3}$ & 1.0 & IV/III & $-1.32[2]$ & 330 & [3] \\
\hline $\mathrm{Np}(\mathrm{III})$ & $\mathrm{K}_{2} \mathrm{CO}_{3}$ & 3.0 & IV/III & - & 140 & [3] \\
\hline $\mathrm{Pu}(\mathrm{V})$ & $\mathrm{Na}_{2} \mathrm{CO}_{3}$ & 0.05 & $\mathrm{VI} / \mathrm{V}$ & $0.334[1]$ & 2.73 & [1] \\
\hline $\mathrm{Pu}(\mathrm{III})$ & $\mathrm{K}_{2} \mathrm{CO}_{3}$ & 1.0 & IV/III & $-0.495[2]$ & 70 & [3] \\
\hline $\mathrm{Pu}(\mathrm{III})$ & $\mathrm{K}_{2} \mathrm{CO}_{3}$ & 1.1 & IV/III & - & 56 & [3] \\
\hline $\mathrm{Pu}(\mathrm{III})$ & $\mathrm{K}_{2} \mathrm{CO}_{3}$ & 4.3 & IV/III & - & 67 & [3] \\
\hline $\mathrm{Am}(\mathrm{III})$ & $\mathrm{K}_{2} \mathrm{CO}_{3}$ & 3.0 & IV/III & $0.86[2]$ & 2.5 & [3] \\
\hline $\operatorname{Am}(\mathrm{III})$ & $\mathrm{K}_{2} \mathrm{CO}_{3}$ & 4.6 & IV/III & - & 2.7 & [3] \\
\hline $\operatorname{Am}(\mathrm{III})$ & $\mathrm{K}_{2} \mathrm{CO}_{3}$ & 6.0 & IV/III & - & 1.5 & [3] \\
\hline $\mathrm{Ce}(\mathrm{III})$ & $\mathrm{K}_{2} \mathrm{CO}_{3}$ & 0.75 & IV/III & - & 4.3 & [3] \\
\hline $\mathrm{Ce}(\mathrm{III})$ & $\mathrm{K}_{2} \mathrm{CO}_{3}$ & 1.5 & IV/III & - & 6.7 & [3] \\
\hline $\mathrm{Ce}(\mathrm{III})$ & $\mathrm{K}_{2} \mathrm{CO}_{3}$ & 3.0 & IV/III & - & 9.0 & [3] \\
\hline
\end{tabular}

${ }^{\text {a}}$ References:

[1] Mulac et al. 1984

[2] Fedoseev et al. 1979

[3] Gogolev 1990

\subsubsection{Alkaline Medium}

If one compares the potentials of the pairs of neptunium, plutonium, and americium in alkaline solutions with the water radiolysis product potentials, it is possible to conclude that $\mathrm{e}_{\mathrm{aq}}^{-}$is able to reduce the compounds of these elements in any high oxidation state, and the radical ion $\mathrm{O}^{-}$is able to oxidize the compounds of these elements in any low valent state. 
The radical ion $\mathrm{O}_{2}^{-}$is a reducing agent for $\mathrm{Np}(\mathrm{VII}), \mathrm{Np}(\mathrm{VI}), \mathrm{Pu}(\mathrm{VII}), \mathrm{Pu}(\mathrm{VI}), \mathrm{Am}(\mathrm{VII})$, and $\mathrm{Am}(\mathrm{VI})$; however, it is an oxidizing agent for $\mathrm{Np}$ (III), $\mathrm{Np}$ (IV), $\mathrm{Pu}(\mathrm{III})$, and $\mathrm{Pu}$ (IV). Hydrogen peroxide should reduce Np(VII), Np(VI), Pu(VII), Pu(VI), Am(VII), and Am(VI) and oxidize $\mathrm{Np}$ (III), $\mathrm{Np}$ (IV), $\mathrm{Pu}$ (III), $\mathrm{Pu}(\mathrm{IV})$, and $\mathrm{Am}(\mathrm{III})$. The radical ions $\mathrm{O}_{3}^{-}$and $\mathrm{CO}_{3}^{-}$ should oxidize the compounds of low valency. Experimental results confirm these conclusions.

Thermodynamic values allow evaluation of the possible reaction pathways but do not allow calculation of the rate of one or another reaction. Kinetic restrictions connected with the changes in the structure [e. g. on the transition from $\mathrm{Np}(\mathrm{IV})$ to $\mathrm{Np}(\mathrm{V})$ and vice versa] can vary the reaction rate.

Pulse radiolysis with spectrophotometric registration of short-lived species was used for the determination of rate constants for the reactions of $\mathrm{Np}(\mathrm{VII}), \mathrm{Np}(\mathrm{VI}), \mathrm{Np}(\mathrm{V}), \mathrm{Pu}$ (VII), and $\mathrm{Pu}(\mathrm{VI})$ with $\mathrm{e}_{\mathrm{aq}}^{-}, \mathrm{Np}(\mathrm{VI})$ with $\mathrm{O}^{-}, \mathrm{Np}(\mathrm{VI})$ and $\mathrm{Np}(\mathrm{V})$ with $\mathrm{O}_{3}^{-}$and $\mathrm{CO}_{3}^{-}$, and $\mathrm{Np}(\mathrm{VII})$ with $\mathrm{Np}(\mathrm{V})$. The solutions of neptunium or plutonium ions saturated with argon or $\mathrm{N}_{2} \mathrm{O}$ were irradiated with electron pulses. The initial solutions of $\mathrm{Np}(\mathrm{VI})$ and $\mathrm{Pu}(\mathrm{VI})$ were prepared from specially purified samples by evaporation with perchloric acid to the appearance of white vapors. Neptunium(V) was prepared by the reduction of $\mathrm{Np}(\mathrm{VI})$ and the precipitation of $\mathrm{NpO}_{2} \mathrm{OH}$ by ammonia; then $\mathrm{NpO}_{2} \mathrm{OH}$ was dissolved in $\mathrm{HClO}_{4}$. Valence determination was performed spectrophotometrically. The solutions of $\mathrm{Np}$ (VII) and $\mathrm{Pu}(\mathrm{VII})$ were prepared by the oxidation of $\mathrm{Np}(\mathrm{VI})$ and $\mathrm{Pu}(\mathrm{VI})$ in alkaline solutions with ozone.

\subsubsection{Rate constants of $\mathrm{e}_{\mathrm{aq}}^{-}$reactions with neptunium and plutonium ions.}

The reactions

$$
\begin{gathered}
\mathrm{H}_{2} \mathrm{O}-\mathrm{e}_{\mathrm{aq}}^{-}, \mathrm{H}, \mathrm{OH}, \mathrm{H}_{2} \mathrm{O}_{2}, \mathrm{H}_{2}, \mathrm{H}_{\mathrm{aq}}^{+} \\
\mathrm{H}+\mathrm{OH}^{-} \rightleftarrows \mathrm{e}_{\mathrm{aq}}^{-}+\mathrm{H}_{2} \mathrm{O} \\
\mathrm{OH}+\mathrm{OH}^{-} \rightleftarrows \mathrm{O}^{-}+\mathrm{H}_{2} \mathrm{O} \\
\mathrm{H}_{2} \mathrm{O}_{2}+\mathrm{OH}^{-} \rightleftarrows \mathrm{HO}_{2}^{-}+\mathrm{H}_{2} \mathrm{O}
\end{gathered}
$$

occur in deaerated alkaline solutions as a result of the action of the electron pulse. In this system, in the absence of solutes, $\mathrm{e}_{\mathrm{aq}}^{-}$disappears predominantly by the following reactions:

$$
\mathrm{e}_{\mathrm{aq}}^{-}+\mathrm{O}^{-}+\mathrm{H}_{2} \mathrm{O} \rightarrow 2 \mathrm{OH}^{-}
$$




$$
\begin{gathered}
\mathrm{e}_{\mathrm{aq}}^{-}+\mathrm{e}_{\mathrm{aq}}^{-}+2 \mathrm{H}_{2} \mathrm{O} \rightarrow \mathrm{H}_{2}+2 \mathrm{OH}^{-} \\
\mathrm{e}_{\mathrm{aq}}^{-}+\mathrm{H}_{2} \mathrm{O}_{2} \rightarrow \mathrm{OH}+\mathrm{OH}^{-} \\
\mathrm{e}_{\mathrm{aq}}^{-}+\mathrm{X} \rightarrow \text { Products }
\end{gathered}
$$

Here $\mathrm{X}$ are unidentified impurities.

Obviously, reactions (21 to 24) should be taken into account upon the determination of rate constants of reactions between $\mathrm{e}_{\mathrm{aq}}^{-}$and neptunium and plutonium ions. The less these reactions contribute to the total decay of $\mathrm{e}_{\mathrm{aq}}^{-}$, the more accurate the measurement of the rate constant of the respective reaction becomes. The lifetime of $e_{\mathrm{aq}}^{-}$increases with increasing alkali concentration. At greater than $5 \mathrm{M} \mathrm{OH}^{-}$, the $\mathrm{e}_{\mathrm{aq}}^{-}$lifetime is sufficiently long for the accurate determination of the constants (Pikaev et al. 1973). To provide the increase in the $\mathrm{e}_{\mathrm{sq}}^{-}$lifetime at less than $5 \mathrm{M} \mathrm{OH}^{-}, 5 \times 10^{-3} \mathrm{M} \mathrm{CH}_{3} \mathrm{OH}$ were added to the solution. Methanol scavenging of $\mathrm{O}^{-}$radical ions suppresses reaction (21) and, as a consequence, decreases the $\mathrm{e}_{\mathrm{aq}}^{-}$decay rate.

The rate constants of $\mathrm{e}_{\mathrm{aq}}^{-}$reactions with neptunium and plutonium ions were determined from curves of $\mathrm{e}_{\mathrm{aq}}^{-}$optical absorption decay at $650 \mathrm{~nm}$ (at greater than $7.5 \mathrm{M} \mathrm{OH}$ ) or $700 \mathrm{~nm}$ (at less than $7.5 \mathrm{M} \mathrm{OH}^{-}$) in the presence of different concentrations of actinide ions. The correction taking into account the participation of $\mathrm{e}_{\mathrm{aq}}^{-}$in reactions $(21$ to 24$)$ or $(22,24)$ (in the presence or in the absence of $\mathrm{CH}_{3} \mathrm{OH}$, respectively) was introduced to the calculation of the constants. The measured rate constants of reactions:

$$
\begin{aligned}
& \mathrm{e}_{\mathrm{aq}}^{-}+\mathrm{Np}(\mathrm{VII}) \rightarrow \mathrm{Np}(\mathrm{VI}) \\
& \mathrm{e}_{\mathrm{aq}}^{-}+\mathrm{Np}(\mathrm{VI}) \rightarrow \mathrm{Np}(\mathrm{V}) \\
& \mathrm{e}_{\mathrm{aq}}^{-}+\mathrm{Np}(\mathrm{V}) \rightarrow \mathrm{Np}(\mathrm{IV}) \\
& \mathrm{e}_{\mathrm{aq}}^{-}+\mathrm{Pu}(\mathrm{VII}) \rightarrow \mathrm{Pu}(\mathrm{VI}) \\
& \mathrm{e}_{\mathrm{aq}}^{-}+\mathrm{Pu}(\mathrm{VI}) \rightarrow \mathrm{Pu}(\mathrm{V})
\end{aligned}
$$


are shown in Tables 5-6 and 5-7.

Table 5-6. Rate Constants of Reactions of $\mathrm{e}_{\mathrm{aq}}^{-}$with Neptunium Ions (Pikaev et al. 1973; Pikaev et al. 1976).

\begin{tabular}{|c|c|c|c|}
\hline Ion & [Ion] x $10^{5}, \mathrm{M}$ & {$\left[\mathrm{OH}^{-}\right], \mathrm{M}$} & $\mathrm{k} \times 10^{-10}, \mathrm{M}^{-1} \mathrm{~s}^{-1}$ \\
\hline \multirow[t]{9}{*}{$\mathrm{Np}$ (VII) } & 2 & 0.1 & $2.9 \pm 0.3$ \\
\hline & 2 & 0.5 & $3.2 \pm 0.6$ \\
\hline & 4 & 1.0 & $2.0 \pm 0.4$ \\
\hline & 3 & 2.0 & $2.1 \pm 0.4$ \\
\hline & 4 & 5.0 & $1.7 \pm 0.2$ \\
\hline & 4 & 7.5 & $1.3 \pm 0.2$ \\
\hline & 4 & 10.0 & $0.88 \pm 0.06$ \\
\hline & 4 & 12.5 & $0.6 \pm 0.1$ \\
\hline & 8 & 12.5 & $0.8 \pm 0.1$ \\
\hline \multirow[t]{8}{*}{$\mathrm{Np}(\mathrm{VI})$} & 1.5 & 0.5 & $2.3 \pm 0.6$ \\
\hline & 5.3 & 1.0 & $1.3 \pm 0.6$ \\
\hline & 2.0 & 2.0 & $1.3 \pm 0.2$ \\
\hline & 5.3 & 2.0 & $1.1 \pm 0.2$ \\
\hline & 5.3 & 5.0 & $2.0 \pm 0.6$ \\
\hline & 5.3 & 7.5 & $1.1 \pm 0.2$ \\
\hline & 5.3 & 10.0 & $0.83 \pm 0.08$ \\
\hline & 5.3 & 12.5 & $0.68 \pm 0.07$ \\
\hline \multirow[t]{6}{*}{$\mathrm{Np}(\mathrm{V})$} & 4.4 & 1.0 & $0.50 \pm 0.06$ \\
\hline & 4.4 & 2.0 & $0.61 \pm 0.08$ \\
\hline & 4.4 & 5.0 & $0.66 \pm 0.07$ \\
\hline & 5.3 & 5.0 & $0.52 \pm 0.07$ \\
\hline & 4.4 & 7.5 & $0.32 \pm 0.04$ \\
\hline & 7.5 & 7.5 & $0.30 \pm 0.03$ \\
\hline
\end{tabular}


The reaction rates for all the studied ions decrease noticeably at $\mathrm{OH}^{-}$concentrations greater than 7.5 M. Several reasons for the decreasing rate of $\mathrm{e}_{\mathrm{aq}}^{-}$reactions in high-concentrated solutions of alkalies were postulated (Pikaev 1973). They are the viscosity of such solutions, the capture of electrons into deeper traps (the $\lambda_{\max }$ of the $\mathrm{e}_{\mathrm{aq}}^{-}$optical absorption band is shifted to shorter wavelengths [Pikaev 1976]), the formation of ionic pairs $\mathbf{M}^{+} \ldots \cdot \mathrm{e}_{\mathrm{aq}}^{-}$(Gopithathan et al. 1970; Kabakchi 1971, Kabakchi and Shubin 1972) which can be less reactive, the change in the activity coefficients at high ionic strengths and so on.

It was suggested that the rate of reactions between $N p(V I)$ and $e_{\mathrm{aq}}^{-}$is controlled by diffusion; the tunnel electron transfer plays an important role in the reaction of $\mathrm{Np}$ (VII) (Pikaev et al. 1973). The calculation of diffusion rate constants, $k_{\mathrm{dif}}$, for reactions of $\mathrm{e}_{\mathrm{aq}}^{-}$with actinide ions is considered (Pikaev et al. 1975). In alkaline solutions, $\mathrm{Np}$ (VII) and $\mathrm{Pu}$ (VII) exist as complex ions $\mathrm{MO}_{4}(\mathrm{OH})_{2}^{3-}$ (Krot et al. 1977). Because of it, the correction due to the salt effect by means of the Brönsted-Bjerrum equation was introduced into the rate constant of reaction between $\mathrm{e}_{\mathrm{aq}}^{-}$and $\mathrm{Np}$ (VII) in $0.1 \mathrm{M} \mathrm{KOH}$ solution. At a $=1.8 \AA$ [see equation (15)], $\mathrm{k}_{\mathrm{o}}=7.2 \times 10^{9} \mathrm{M}^{-1} \mathrm{~s}^{-1}\left(\mathrm{Z}_{\mathrm{X}}=-3\right)$ or $\mathrm{k}_{\mathrm{o}}=1.1 \times 10^{10} \mathrm{M}^{-1} \mathrm{~s}^{-1}\left(\mathrm{Z}_{\mathrm{X}}=-2\right.$, if an ionic pair with $\mathrm{K}^{+}$is formed in $0.1 \mathrm{M} \mathrm{KOH}$ solution).

The constant of the diffusion-controlled reaction rate for charged species is calculated by the Debye equation [equation (16)]. The $\mathrm{r}_{\mathrm{X}}$ and $\mathrm{D}_{\mathrm{x}}$ values for $\mathrm{NpO}_{4}(\mathrm{OH})_{2}^{3-}$ are unknown. However, for other ions of similar structure, it was proposed that $r_{X}$ lies in the range 2.5 to $3.5 \AA$ and $D_{\mathrm{x}}$ is approximately $10^{-5} \mathrm{~cm}^{2} \mathrm{~s}^{-1}$. Then for $\mathrm{Np}(\mathrm{VII}), \mathrm{k}_{\mathrm{dif}}$ lies in the range $1.4 \times 10^{9}$ to $2.4 \times 10^{9} \mathrm{M}^{-1} \mathrm{~s}^{-1}\left(\mathrm{Z}_{\mathrm{X}}=-3\right)$ or $3.8 \times 10^{9}$ to $6.5 \times 10^{9} \mathrm{M}^{-1} \mathrm{~s}^{-1}\left(\mathrm{Z}_{\mathrm{x}}=-2\right)$. As seen, $\mathrm{k}_{\mathrm{dif}}$ is considerably less than $\mathrm{k}_{\mathrm{o}}$. Thus, it is possible to believe that the tunnel electron transfer plays an important role in the reactions of $\mathrm{e}_{\mathrm{aq}}^{-}$with $\mathrm{Np}(\mathrm{VII})$.

In Section 2.0 it was shown, based on analyses of electrochemical and chemical data, that $\mathrm{Np}(\mathrm{VI})$ and $\mathrm{Np}(\mathrm{V})$ in alkaline solutions exist as $\mathrm{NpO}_{4}\left(\mathrm{H}_{2} \mathrm{O}\right)_{2}^{2-}$ or $\mathrm{NpO}_{2}(\mathrm{OH})_{4}^{2-}$ and $\mathrm{NpO}_{2}(\mathrm{OH})_{3} \mathrm{H}_{2} \mathrm{O}^{2-}$, respectively. These ions have the coordination number 6 and similar structures. The diffusion limits of the rate constants of $e_{\mathrm{aq}}^{-}$reactions with $\mathrm{Np}(\mathrm{VI})$ and $\mathrm{Np}(\mathrm{V})$ may be evaluated by means of the Debye equation. The radius of $\mathrm{NpO}_{4}\left(\mathrm{H}_{2} \mathrm{O}\right)_{2}^{2-}$ is equal to the sum of the covalent radius of $\mathrm{Np}(\mathrm{VI})(0.141 \mathrm{~nm}$ [Zachariasen 1954]) and the two covalent radii of oxygen $(0.066 \mathrm{~nm}$ [Handbook of Chemist 1971]). The radius of $\mathrm{NpO}_{2}(\mathrm{OH})_{3} \mathrm{H}_{2} \mathrm{O}^{2}$ is also equal to the sum of the covalent radius of $\mathrm{Np}(\mathrm{V})(0.149 \mathrm{~nm}$ [Zachariasen 1954]) and two covalent radii of oxygen. The diffusion coefficients evaluated via the Stokes-Einstein equation [D $=\mathrm{kT} /(6 \pi \eta \mathrm{r})$, where $\eta$ is the viscosity of the solution] are $0.8 \times 10^{-5} \mathrm{~cm}^{2} \mathrm{~s}^{-1}$. The $\mathrm{k}_{\mathrm{dif}}$ values calculated are about $3.9 \times 10^{9} \mathrm{M}^{-1} \mathrm{~s}^{-1}$ for both ions. The correction due to the salt effect was difficult to perform reliably, because the Brönsted-Bjerrum equation can be used only at concentrations less than $0.1 \mathrm{M}$. The rate constants of $e_{\mathrm{aq}}^{-}$reactions with $\mathrm{Np}(\mathrm{VI})$ and $\mathrm{Np}(\mathrm{V})$ were measured in the case of 0.5 and $1.0 \mathrm{M} \mathrm{OH}^{-}$solutions. Despite the uncertainties, it is possible to conclude that $\mathrm{e}_{\mathrm{aq}}^{-}$reacts with $\mathrm{Np}(\mathrm{VI})$ with a rate close to the diffusion limit. In the case of $\mathrm{Np}(\mathrm{V})$, the rate constant is somewhat lower, probably because of the shift of the potential for $\mathrm{Np}(\mathrm{V}) /(\mathrm{IV})$ pair to the negative range (approximately by $1 \mathrm{~V}$ in comparison with the potential for $\mathrm{Np}(\mathrm{VI}) /(\mathrm{V})$ pair). 
Table 5-7. Influence of the Medium on the Rate Constants of Reactions Between $\mathrm{e}_{\mathrm{aq}}^{-}$and Plutonium Ions

(Pikaev et al. 1973).

\begin{tabular}{|c|c|c|}
\hline Ion & {$\left[\mathrm{OH}^{-}\right], \mathrm{M}$} & $\mathrm{k} \times 10^{-10}, \mathrm{M}^{-1} \mathrm{~s}^{-1}$ \\
\hline \multirow[t]{4}{*}{$\mathrm{Pu}(\mathrm{VII})$} & 1.0 & $3.5 \pm 0.6$ \\
\hline & 2.0 & $4.2 \pm 0.8$ \\
\hline & 5.0 & $2.3 \pm 0.4$ \\
\hline & 7.5 & $2.0 \pm 0.4$ \\
\hline \multirow[t]{3}{*}{$\mathrm{Pu}(\mathrm{VI})$} & 2.0 & $1.9 \pm 0.3$ \\
\hline & 5.0 & $2.0 \pm 0.3$ \\
\hline & 7.5 & $0.66 \pm 0.08$ \\
\hline
\end{tabular}

From Table 5-7, it is seen that ions of Pu(VI) and especially Pu(VII) in alkaline media are characterized by a high reactivity toward $\mathrm{e}_{\mathrm{aq}}^{-}$. The rate constants for Pu(VII) are somewhat higher than for the analogous valent state of neptunium. The rate of the $\mathrm{Pu}(\mathrm{VI})$ reaction is believed to be controlled by diffusion (Pikaev et al. 1975; Pikaev et al. 1973). The tunnel mechanism was proposed for the reactions of $e_{\mathrm{aq}}^{-}$with both Pu(VII) and $\mathrm{Np}$ (VII) (Pikaev et al. 1975; Pikaev et al. 1973).

The fact that the values of the rate constants for $\mathrm{Np}(\mathrm{VI})$ and $\mathrm{Pu}(\mathrm{VI})$ are similar testifies that the form of the existence of these ions in alkaline media is the same. The ionic forms of $\mathrm{Np}$ (VII) and $\mathrm{Pu}(\mathrm{VII})$ are also the same, and the difference in the rate constants $\left(\mathrm{k}\left[\mathrm{e}_{\mathrm{aq}}^{-}+\mathrm{Pu}(\mathrm{VII})\right]\right.$ is greater than $\left.\mathrm{k}\left[\mathrm{e}_{\mathrm{aq}}^{-}+\mathrm{Np}(\mathrm{VII})\right]\right)$ may be caused by the difference in the oxidizing properties of these ions [the oxidation potential of Pu(VII) is higher than the respective potential of $\mathrm{Np}(\mathrm{VII})$ by $0.26 \mathrm{~V}]$.

5.1.2.2 Rate Constants of $\mathrm{O}^{-}$with $\mathrm{Np}(\mathrm{VI})$ and $\mathrm{Np}(\mathrm{V})$. It has been shown that the $\mathrm{Np}(\mathrm{VI})$ ion in alkaline solution saturated with $\mathrm{N}_{2} \mathrm{O}$ is oxidized to the heptavalent state by a radiation-chemical mechanism (Pikaev et al. 1969; Pikaev et al. 1970). Nitrous oxide converts $\mathrm{e}_{\mathrm{aq}}^{-}$to the radical ion $\mathrm{O}^{-}$

$$
\mathrm{e}_{\mathrm{aq}}^{-}+\mathrm{N}_{2} \mathrm{O} \rightarrow \mathrm{N}_{2}+\mathrm{O}^{-}
$$

which oxidizes the $\mathrm{Np}(\mathrm{VI})$ ion

$$
\mathrm{O}^{-}+\mathrm{Np}(\mathrm{VI}) \rightarrow \mathrm{O}^{2-}+\mathrm{Np}(\mathrm{VII})
$$


The value of $k_{31}$ was measured by pulse radiolysis with spectrophotometric registration of $\mathrm{Np}$ (VII) ions (Pikaev and Shilov 1978). The optical absorption spectrum of Np(VII) ions in alkaline media has bands with peaks at 412 and $620 \mathrm{~nm}$. The radical ions $\mathrm{O}_{3}^{-}$and $\mathrm{CO}_{3}^{-}$can be formed upon radiolysis of alkaline water as a result of the reactions of $\mathrm{O}$ and $\mathrm{OH}$ with oxygen and carbonate impurities $\left(\mathrm{O}_{3}^{-}\right.$can also be a product of radiolysis). Both $\mathrm{O}_{3}^{-}$and $\mathrm{CO}_{3}^{-}$ have optical absorption in the region useful in the identification of Np(VII). Because of the overlapping absorption, initial studies used solutions not containing $\mathrm{Np}$ (VII) ions (Pikaev and Shilov 1978).

$$
\begin{gathered}
\mathrm{O}^{-}+\mathrm{O}_{2} \rightarrow \mathrm{O}_{3}^{-} \\
\mathrm{OH}+\mathrm{CO}_{3}^{2-} \rightarrow \mathrm{OH}^{-}+\mathrm{CO}_{3}^{-}
\end{gathered}
$$

As a result of irradiation, a short-lived optical absorption at $412 \mathrm{~nm}$ appears in $1 \mathrm{M} \mathrm{LiOH}$ solution saturated with $\mathrm{N}_{2} \mathrm{O}$. After one pulse (dose 100-150 Gy), the absorption is negligibly small but becomes noticeable after 2 to 3 pulses. This absorption is due to the formation of ozonide [reaction (32)]. Molecular oxygen is accumulated because of the oxidation of hydrogen peroxide formed in spurs and in the bulk of the solution:

$$
\mathrm{O}^{-}+\mathrm{O}^{-}+\mathrm{H}_{2} \mathrm{O} \rightarrow \mathrm{HO}_{2}^{-}+\mathrm{OH}^{-}
$$

The absorption at $620 \mathrm{~nm}$ was small after both one and 20 pulses.

Intense absorption at $620 \mathrm{~nm}$ appears after one pulse (dose $100-150 \mathrm{~Gy}$ ) in $0.03 \mathrm{M} \mathrm{LiOH}$ solution saturated with $\mathrm{N}_{2} \mathrm{O}$ due to the radical ion $\mathrm{CO}_{3}^{-}$. The peak of the respective band is at $600 \mathrm{~nm}$ (Weeks and Rabani 1966). After second and third pulses, the absorption at $620 \mathrm{~nm}$ decreases but the absorption at $412 \mathrm{~nm}$ increases. This is because the oxygen reaction, (32), begins to compete with reaction (33). The $\mathrm{CO}_{3}^{-}$absorption does not appear in more concentrated $\mathrm{LiOH}$ solutions; the reason is the low rate constant of the reaction

$$
\mathrm{O}^{-}+\mathrm{CO}_{3}^{2-} \rightarrow \mathrm{O}^{2-}+\mathrm{CO}_{3}^{-}
$$

Analogous results were obtained for $\mathrm{NaOH}$ solutions.

Increase in optical absorption in the region of 412 and $620 \mathrm{~nm}$, i.e. the occurrence of reaction (31), was observed upon irradiation of solutions saturated with $\mathrm{N}_{2} \mathrm{O}$ containing 0.03 to $2 \mathrm{M} \mathrm{LiOH}$ and (4 to 9) $\times 10^{-3} \mathrm{M} \mathrm{Np}$ (VI). The maximal value of optical absorption was observed 10 to $35 \mu \mathrm{s}$ after the pulse, depending on the $\mathrm{Np}(\mathrm{VI})$ concentration. 
The $\mathrm{Np}$ (VII) yield was 3.2 to $4.0 \mathrm{ion} / 100 \mathrm{eV}$. It is necessary to take into account the reactions (17), (18), (26), (30), (31), and (36)

$$
\mathrm{H}+\mathrm{Np}(\mathrm{VI}) \rightarrow \mathrm{H}^{+}+\mathrm{Np}(\mathrm{V})
$$

for the theoretical calculation of the yield. Because of it

$$
\mathrm{G}[\mathrm{Np}(\mathrm{VII})]=\mathrm{G}_{\mathrm{OH}}+\mathrm{B}\left(\mathrm{G}_{c_{-\bar{m}}}+\mathrm{AG}_{\mathrm{H}}\right)
$$

where

$$
\begin{aligned}
& \mathrm{A}=\mathrm{k}_{18}[\mathrm{OH}] /\left(\mathrm{k}_{18}\left[\mathrm{OH}^{-}\right]+\mathrm{k}_{36}[\mathrm{~Np}(\mathrm{VI})]\right) \\
& \mathrm{B}=\mathrm{k}_{30}\left[\mathrm{~N}_{2} \mathrm{O}\right] /\left(\mathrm{k}_{30}\left[\mathrm{~N}_{2} \mathrm{O}\right]+\mathrm{k}_{26}[\mathrm{~Np}(\mathrm{VI})] .\right.
\end{aligned}
$$

Because $\mathrm{k}_{36}=4.0 \times 10^{8} \mathrm{M}^{-1} \mathrm{~s}^{-1}$ for acid solution (Shilov and Pikaev 1982) (but it should be lower for alkaline solutions), $\mathrm{k}_{18}=2.1 \times 10^{7} \mathrm{M}^{-1} \mathrm{~s}^{-1}$ (Pikaev and Kabakchi 1982), and $[\mathrm{Np}(\mathrm{VI})]<<\left[\mathrm{OH}^{-}\right]$, then $\mathrm{A} \approx 1$.

If the $\mathrm{G}$ values of water radiolysis products in alkaline media (Table 5-1) are inserted into equation (37), the $\mathrm{N}_{2} \mathrm{O}$ concentration is $0.02 \mathrm{M}$, and $\mathrm{k}_{30}=8.7 \times 10^{9} \mathrm{M}^{-1} \mathrm{~s}^{-1}$, then for $9 \times 10^{-3} \mathrm{M} \mathrm{Np}$ (VI) in $1 \mathrm{M} \mathrm{LiOH}$, B is about 6 and the yield should be 5.0 ion/100 eV. The comparison of experimental and calculated yields shows that not all the radical ions $\mathrm{O}^{-}$are consumed in reaction (31); partial combination of the $\mathrm{O}^{-}$is probable.

However, the main part of radical ions $\mathrm{O}^{-}$oxidize $\mathrm{Np}(\mathrm{VI})$, and it is possible to believe that the accumulation of $\mathrm{Np}$ (VII) follows first-order reaction kinetics via $\mathrm{Np}(\mathrm{VI})$ and $\mathrm{O}^{-}$:

$$
\mathrm{d}[\mathrm{Np}(\mathrm{VII})] / \mathrm{dt}=\mathrm{k}_{31}[\mathrm{~Np}(\mathrm{VI})]\left[\mathrm{O}^{-}\right]
$$

Assuming that $\left[\mathrm{O}^{-}\right]=[\mathrm{Np}(\mathrm{VII})]_{\max }-[\mathrm{Np}(\mathrm{VII})]$,

$$
\ln \left\{[\mathrm{Np}(\mathrm{VII})]_{\max }-[\mathrm{Np}(\mathrm{VII})]\right\}=-\mathrm{k}^{\prime} \mathrm{t}+\text { const, }
$$

where $k^{\prime}=k_{31}[N p(V I)]$. Substituting the $N p(V I I)$ concentration by the optical density, $D$, which is proportional to $\mathrm{Np}$ (VII) concentration, we have

$$
2.3 \log \left(\mathrm{D}_{\max }-\mathrm{D}\right)=-\mathrm{k}^{\prime} \mathrm{t}+\text { const }
$$

The mean obtained values of $\mathrm{k}^{\prime}$ and $\mathrm{k}_{31}$ for solutions with various concentrations of $\mathrm{LiOH}$ are shown in Table 5-8. 
As seen from Table 5-8, the rate constants within the range of LiOH concentrations from 0.72 to $2.0 \mathrm{M}$ are virtually the same. The increase in $0.033 \mathrm{M}$ solution can be explained by the fact that under these conditions, part of the $\mathrm{OH}$ radicals exists in the undissociated (OH) form. The reaction rate for $\mathrm{OH}$ should be higher than for $\mathrm{O}^{-}$.

Increase in optical absorption both at 620 and $412 \mathrm{~nm}$ was observed after the electron pulse in $\mathrm{NaOH}$ solutions saturated in $\mathrm{N}_{2} \mathrm{O}$ containing $\mathrm{Np}$ (VI). These observations give evidence for the appearance of $\mathrm{Np}$ (VII) in the solution. The $\mathrm{Np}$ (VII) yield was 3.2 to $4.1 \mathrm{ion} / 100 \mathrm{eV}$. The rate constants of reactions between $\mathrm{Np}(\mathrm{VI})$ and $\mathrm{O}^{-}$in 0.5 to $1.7 \mathrm{M} \mathrm{NaOH}$ solutions are given in Table 5-9. Comparison of the data from Tables 5-8 and 5-9 shows that the constants for $\mathrm{LiOH}$ and $\mathrm{NaOH}$ solutions are close.

Table 5-8. Rate Constants of Reactions Between $\mathrm{Np}(\mathrm{VI})$ and $\mathrm{O}^{-}$at Different Concentrations of LiOH (Pikaev and Shilov 1978).

\begin{tabular}{|c|c|c|c|}
\hline$[\mathrm{LiOH}], \mathrm{M}$ & {$[\mathrm{Np}(\mathrm{VII})] \times 10^{3}, \mathrm{M}$} & $\mathrm{k}^{\prime} \times 10^{-5}, \mathrm{~s}^{-1}$ & $\mathrm{k}_{31} \times 10^{-7}, \mathrm{M}^{-1} \mathrm{~s}^{-1}$ \\
\hline 2 & 9.4 & 4.8 & 5.1 \\
\hline 1.72 & 10.0 & 4.2 & 4.2 \\
\hline 1.03 & 9.4 & 4.0 & 4.2 \\
\hline 0.51 & 8.1 & 3.4 & 4.2 \\
\hline 0.072 & 5.4 & 2.9 & 5.4 \\
\hline 0.033 & 4.1 & 3.3 & 8.0 \\
\hline
\end{tabular}

Table 5-9. Rate Constants of Reaction Between $\mathrm{Np}(\mathrm{VI})$ and $\mathrm{O}^{-}$at Different $\mathrm{NaOH}$ Concentrations (Pikaev and Shilov 1978).

\begin{tabular}{|c|c|c|c|}
\hline$[\mathrm{NaOH}], \mathrm{M}$ & {$[\mathrm{Np}(\mathrm{VI})], \times 10^{3}, \mathrm{M}$} & $\mathrm{k}^{\prime} \times 10^{-5}, \mathrm{~s}^{-1}$ & $\mathrm{k}_{31} \times 10^{-7}, \mathrm{M}^{-1} \mathrm{~s}^{-1}$ \\
\hline 1.7 & 2.7 & 1.7 & 6.3 \\
\hline 1.0 & 2.7 & 1.4 & 5.2 \\
\hline 1.0 & 2.7 & 1.9 & 7.0 \\
\hline 0.8 & 4.1 & 1.8 & 4.4 \\
\hline 0.5 & 2.2 & 1.8 & 8.2 \\
\hline
\end{tabular}


To elucidate the mechanism of charge transfer in reaction (31), the value of $k_{31}$ was compared to the diffusion limit of $\mathrm{k}_{31}$ calculated by means of the Debye equation. The radius of $\mathrm{NpO}_{4}\left(\mathrm{H}_{2} \mathrm{O}\right)_{2}^{2-}$ is $0.273 \mathrm{~nm}$ (see above consideration); the radius of $\mathrm{O}^{-}$is the arithmetic mean between the covalent radius of oxygen and the radius of $\mathrm{O}^{2-}(0.136 \mathrm{~nm}$ [Handbook of Chemist 1971]). The diffusion coefficient of $\mathrm{O}^{-}$was evaluated via the Stokes-Einstein equation (see above consideration). The calculated value of $k_{\text {dif }}$ is approximately $6 \times 10^{8} \mathrm{M}^{-1} \mathrm{~s}^{-1}$. Therefore, the interaction of $\mathrm{Np}(\mathrm{VI})$ with $\mathrm{O}$ is not controlled by diffusion. It is possible to suggest that the rate of reaction (31) is determined by the abstraction of a $\mathrm{H}$ atom from a water molecule in the $\mathrm{NpO}_{4}\left(\mathrm{H}_{2} \mathrm{O}\right)_{2}^{2-}$ ion by the radical ion $\mathrm{O}$. Such a reaction occurs, for example, in the case of $\mathrm{Am}(\mathrm{III})$ oxidation by the $\mathrm{OH}$ radical in acid media (Pikaev et al. 1977a). The value of $k\left[N p(V I)+\mathrm{O}^{-}\right]$is less than $\mathrm{k}\left[\mathrm{Am}(\mathrm{III})+\mathrm{OH}^{-}\right.$. The difference is explained by the lower reactivity of $\mathrm{O}^{-}$in comparison with $\mathrm{OH}$ in reactions of $\mathrm{H}$ atom abstraction (Neta and Schuler 1975).

As mentioned in the discussion of the calculation of the $\mathrm{Np}(\mathrm{VII})$ yield immediately after the pulse, part of the $e_{\mathrm{aq}}^{-}$is consumed for the reduction of $\mathrm{Np}$ (VI) according to reaction (26). At given concentrations of $\mathrm{Np}(\mathrm{VI})$ and $\mathrm{N}_{2} \mathrm{O}$, the $\mathrm{Np}(\mathrm{V})$ yield is $1.44 \mathrm{ion} / 100 \mathrm{eV}$. If we take into account the absorbed dose, the initial concentration of $\mathrm{Np}(\mathrm{V})$ is $(1.5$ to 2.2$) \times 10^{-5} \mathrm{M}$. The formed $\mathrm{Np}(\mathrm{V})$ reacts, initially, with $\mathrm{O}$ :

$$
\mathrm{Np}(\mathrm{V})+\mathrm{O}^{-} \rightarrow \mathrm{Np}(\mathrm{VI})+\mathrm{O}^{2-}
$$

The kinetics of reaction (40) was studied using solution containing $1 \mathrm{M} \mathrm{LiOH}$, (1 to 2) $\times 10^{-4} \mathrm{M} \mathrm{Np}(\mathrm{V})$, and saturated with $\mathrm{N}_{2} \mathrm{O}$, by the increase in optical density at $300 \mathrm{~nm}$ where $\mathrm{Np}(\mathrm{VI})$ absorbs (Gogolev et al. 1989a). The calculation was carried out by means of equation (39). It was found that $k_{40}$ is $4.7 \times 10^{8} \mathrm{M}^{-1} \mathrm{~s}^{-1}$.

With this data, the contribution of reactions (31) and (34) to the consumption of $O^{-}$radical ions can be evaluated. The fraction due to reaction $(40)$ is

$$
\mathrm{k}_{40}[\mathrm{~Np}(\mathrm{~V})] /\left(\mathrm{k}_{40}[\mathrm{~Np}(\mathrm{VI})]+2 \mathrm{k}_{34}\left[\mathrm{O}^{-}\right]_{0}\right) \approx 0.01
$$

The fraction due to reaction (31) is about 0.6 .

5.1.2.3 Rate Constants of $\mathrm{O}_{3}^{-}$Reaction with $\mathrm{Np}(\mathrm{VI})$ and $\mathrm{Np}(\mathrm{V})$. The kinetics of reaction of $\mathrm{O}_{3}^{-}$with $\mathrm{Np}(\mathrm{VI})$ and $\mathrm{Np}(\mathrm{V})$ was studied by pulse radiolysis with spectrophotometric registration of short-lived species (Gogolev et al. 1989b) To exclude the formation of colloid forms of $\mathrm{Np}(\mathrm{VI})$ or $\mathrm{Np}(\mathrm{V})$ in 0.2 to $0.5 \mathrm{M}$ solution of $\mathrm{LiOH}, 1$ to $2 \mathrm{~mL}$ of $3 \mathrm{M} \mathrm{LiOH}$ were initially added to slightly-acid 0.02 to $0.03 \mathrm{M}$ solutions of $\mathrm{Np}(\mathrm{VI})$ or to $10^{-3} \mathrm{M}$ solutions of $\mathrm{Np}(\mathrm{V})$. To the $\mathrm{LiOH}$ and $\mathrm{Np}$ solutions, $\mathrm{K}_{2} \mathrm{~S}_{2} \mathrm{O}_{8}$ solution was added. Because $\mathrm{S}_{2} \mathrm{O}_{8}^{2-}$ in alkaline solutions forms products which reduce Np(VII) (Shilov et al. 1971), only freshly prepared solutions were used. 
In aerated solutions of $\mathrm{LiOH}$ containing $0.02 \mathrm{M} \mathrm{K}_{2} \mathrm{~S}_{2} \mathrm{O}_{8}$, an optical absorption band with maximum at $430 \mathrm{~nm}$ belonging to $\mathrm{O}_{3}^{-}$appears as a result of irradiation with the electron pulse (Pikaev 1986). The absorption after the first and second pulses decays following a rate law that is the mean between first and second orders. Further irradiation leads to the decay of optical absorption according to a first-order law.

The appearance of the short-lived absorption at $430 \mathrm{~nm}$ in alkaline solution of $\mathrm{K}_{2} \mathrm{~S}_{2} \mathrm{O}_{8}$ is caused by reactions (17) to (19), (41) to (43), and (32):

$$
\begin{gathered}
\mathrm{e}_{\mathrm{aq}}^{-}+\mathrm{O}_{2} \rightarrow \mathrm{O}_{2}^{-} \\
\mathrm{e}_{\mathrm{aq}}^{-}+\mathrm{S}_{2} \mathrm{O}_{8}^{2-} \rightarrow \mathrm{SO}_{4}^{-}+\mathrm{SO}_{4}^{2-} \\
\mathrm{SO}_{4}^{-}+\mathrm{OH}^{-} \rightarrow \mathrm{SO}_{4}^{2-}+\mathrm{OH}
\end{gathered}
$$

The decay of $\mathrm{O}_{3}^{-}$is due to the shift of reaction (32) to the left and to reactions:

$$
\begin{gathered}
\mathrm{O}_{3}^{-}+\mathrm{H}_{2} \mathrm{O} \rightarrow \mathrm{OH}+\mathrm{O}_{2}+\mathrm{OH}^{-} \\
\mathrm{O}_{3}^{-}+\mathrm{O}^{-} \rightarrow 2 \mathrm{O}_{2}^{-} \\
\mathrm{O}_{3}^{-}+\mathrm{O}_{2}^{-}+\mathrm{H}_{2} \mathrm{O} \rightarrow 2 \mathrm{O}_{2}+2 \mathrm{OH}^{-} \\
\mathrm{O}_{3}^{-}+\mathrm{HO}_{2}^{-}+\mathrm{H}_{2} \mathrm{O} \rightarrow \mathrm{HO}_{2}+\mathrm{O}_{2}+2 \mathrm{OH}^{-} \\
\mathrm{HO}_{2}+\mathrm{OH}^{-} \rightleftarrows \mathrm{O}_{2}^{-}+\mathrm{H}_{2} \mathrm{O}
\end{gathered}
$$

In solutions containing $\mathrm{Np}(\mathrm{VI})$, the optical absorption at $430 \mathrm{~nm}$ decays faster but not to 0 . The residual absorption, which belongs to $\mathrm{Np}$ (VII), is observed for several seconds. The appearance of $\mathrm{Np}(\mathrm{VII})$ is caused by reaction (31) competing with reaction (32) and by the following reaction

$$
\mathrm{Np}(\mathrm{VI})+\mathrm{O}_{3}^{-} \rightarrow \mathrm{Np}(\mathrm{VII})+\mathrm{O}_{2}+\mathrm{O}^{2-}
$$


In the presence of $\mathrm{Np}(\mathrm{VI})$, the optical absorption of $\mathrm{O}_{3}^{-}$decays by a first-order rate law. Because of it

$$
\mathrm{d}\left[\mathrm{O}_{3}^{-}\right] / \mathrm{dt}=\mathrm{k}_{49}[\mathrm{~Np}(\mathrm{VI})]\left[\mathrm{O}_{3}^{-}\right]+\mathrm{k}^{\prime}{ }_{0}\left[\mathrm{O}_{3}^{-}\right]
$$

where $\mathrm{k}_{\mathrm{o}}^{\prime}$ is the apparent rate constant of the first-order decay of $\mathrm{O}_{3}^{-}$in the absence of $\mathrm{Np}(\mathrm{VI})$. Since $[\mathrm{Np}(\mathrm{VI})]>>\left[\mathrm{O}_{3}\right]$, then $d \ln \left[\mathrm{O}_{3}\right]=-\mathrm{kdt}$, where $\mathrm{k}=\mathrm{k}_{49}[\mathrm{~Np}(\mathrm{VI})]+\mathrm{k}^{\prime}{ }_{0}$. If we substitute $\left[\mathrm{O}_{3}^{-}\right]$with the optical density difference $\mathrm{D}-\mathrm{D}_{\infty}$ which is proportional to $\left[\mathrm{O}_{3}^{-}\right.$, (and where $\mathrm{D}$ and $\mathrm{D}_{\infty}$ are the optical densities at a given time and after finishing the decay of $\mathrm{O}_{3}^{-}$respectively) then

$$
2.3 \log \left(\mathrm{D}-\mathrm{D}_{\infty}\right)=-\mathrm{kt}+\text { const }
$$

In addition, the reactions (26), (40) and (52) occur in the system:

$$
\mathrm{Np}(\mathrm{V})+\mathrm{O}_{3}^{-} \rightarrow \mathrm{Np}(\mathrm{VI})+\mathrm{O}_{2}+\mathrm{O}^{2-}
$$

The rate constants of reactions (31) and (40) are $4.6 \times 10^{7}$ (Pikaev and Shilov 1978) and 4.7 x $10^{8} \mathrm{M}^{-1} \mathrm{~s}^{-1}$ (Gogolev et al. 1989a).

The precision of $\mathrm{k}_{49}$ evaluation depends on $\mathrm{Np}(\mathrm{VI})$ concentration and on the fraction $\mathrm{A}$ for the reaction (32) in the total balance of the $\mathrm{O}^{-}$consumption where

$$
\mathrm{A}=\mathrm{k}_{32}\left[\mathrm{O}_{2}\right] /\left(\mathrm{k}_{32}\left[\mathrm{O}_{2}\right]+\mathrm{k}_{31}[\mathrm{~Np}(\mathrm{VI})]+\mathrm{k}_{40}[\mathrm{~Np}(\mathrm{~V})]\right)
$$

Preliminary experiments showed that these contradictory claims may be satisfied in aerated solutions with about $2 \times 10^{-3} \mathrm{M} \mathrm{Np}(\mathrm{VI})$ and greater than $0.02 \mathrm{M} \mathrm{S}_{2} \mathrm{O}_{8}^{2-}$. The applied dose forms $\mathrm{Np}(\mathrm{V})$ concentration that is equal to $\mathrm{BG}_{\mathrm{e}_{\mathrm{in}}} \mathrm{E} \times 10^{3} /(100 \mathrm{~N})$ where $\mathrm{E}$ is the dose in $\mathrm{eV} \mathrm{g}^{-1}, \mathrm{~N}$ is the Avogadro number, and

$$
\mathrm{B}=\mathrm{k}_{26}[\mathrm{~Np}(\mathrm{VI})] /\left(\mathrm{k}_{26}[\mathrm{~Np}(\mathrm{VI})]+\mathrm{k}_{41}\left[\mathrm{O}_{2}\right]+\mathrm{k}_{42}\left[\mathrm{~S}_{2} \mathrm{O}_{8}^{2-}\right]\right) \text {. }
$$

Taking into account that $\mathrm{k}_{26}=2 \times 10^{10}, \mathrm{k}_{41}=2 \times 10^{10}$, and $\mathrm{k}_{42}=1 \times 10^{10} \mathrm{M}^{-1} \mathrm{~s}^{-1}$ (Pikaev and Kabakchi 1982) and $\left[\mathrm{O}_{2}\right]=2 \times 10^{-4} \mathrm{M} ; \mathrm{B}=0.164,[\mathrm{~Np}(\mathrm{~V})]=2.5 \times 10^{-6} \mathrm{M}$ for the experimental conditions, and $A=0.88$. The derived mean values of $k$ and $k_{49}$ for solutions with different concentrations of $\mathrm{LiOH}$ are shown in Table 5-10.

As seen from Table 5-10, the $\mathrm{k}_{49}$ value is constant [about $(2.1 \pm 0.2) \times 10^{5} \mathrm{M}^{-1} \mathrm{~s}^{-1}$ ] when the LiOH concentration decreases from 2.1 to $0.21 \mathrm{M}$. 
The kinetics of reaction (52) was investigated by measuring light absorption at $430 \mathrm{~nm}$ in $1 \mathrm{M} \mathrm{LiOH}$, (1 to 2) $\times 10^{4} \mathrm{M} \mathrm{Np}(\mathrm{V})$, and $0.02 \mathrm{M} \mathrm{K}_{2} \mathrm{~S}_{2} \mathrm{O}_{8}$ solution. Treatment of the experimental data according to equation (51) gives $\mathrm{k}_{52}=(2.1 \pm 0.3) \times 10^{6} \mathrm{M}^{-1} \mathrm{~s}^{-1}$.

Table 5-10. Rate Constants of The Reaction Between $\mathrm{Np}(\mathrm{VI})$ and $\mathrm{O}_{3}^{-}$.

\begin{tabular}{|c|c|c|c|c|}
\hline$[\mathrm{Np}(\mathrm{VI})] \times 10^{5}, \mathrm{M}$ & {$[\mathrm{LiOH}], \mathrm{M}$} & {$\left[\mathrm{K}_{2} \mathrm{~S}_{2} \mathrm{O}_{8}\right] \times 10^{2}, \mathrm{M}$} & $\mathrm{k} \times 10^{-2}, \mathrm{~s}^{-1}$ & $\mathrm{k}_{49} \times 10^{-5}, \mathrm{M}^{-1} \mathrm{~s}^{-1}$ \\
\hline 0 & 2 & 2 & 4 & - \\
\hline 0 & 1 & 2 & 3.3 & - \\
\hline 0 & 0.5 & 2 & 3.0 & - \\
\hline 0 & 0.2 & 2 & 2.3 & - \\
\hline 2.25 & 2.15 & 10 & 8.7 & 2.1 \\
\hline 2.06 & 1.66 & 2 & 8.5 & 2.2 \\
\hline 2.0 & 1.06 & 2 & 7.5 & 2.1 \\
\hline 2.25 & 1.0 & 8.7 & 7.3 & 1.8 \\
\hline 2.0 & 1.0 & 2 & 6.5 & 1.6 \\
\hline 2.0 & 0.53 & 2 & 6.2 & 1.6 \\
\hline 2.0 & 0.42 & 10 & 8.3 & 2.6 \\
\hline 2.8 & 0.31 & 10 & 9.0 & 2.4 \\
\hline 2.0 & 0.22 & 10 & 6.8 & 2.2 \\
\hline 1.0 & 0.21 & 10 & 4.6 & 2.3 \\
\hline
\end{tabular}

5.1.2.4 Rate Constants of $\mathrm{CO}_{3}^{-}$Reaction with $\mathrm{Np}(\mathrm{VI})$ and $\mathrm{Np}(\mathrm{V})$. It is known that the addition of $\mathrm{Na}_{2} \mathrm{CO}_{3}$ up to $1.5 \mathrm{M}$ into a $0.2 \mathrm{M}$ solution of $\mathrm{NaOH}$ has no effect on the value of the potential for the $N p(V I I) /(V I)$ pair (Simakin and Matyashchuk 1969). The redox potential of the $\mathrm{CO}_{3}^{-} / \mathrm{CO}_{3}^{2-}$ pair is $1.5 \mathrm{~V}$ (Henglein 1980). Because of it, there is a possibility for reaction (53) to occur:

$$
\mathrm{CO}_{3}^{-}+\mathrm{Np}(\mathrm{VI}) \rightarrow \mathrm{CO}_{3}^{2-}+\mathrm{Np}(\mathrm{VII})
$$

Reaction (53) was studied by pulse radiolysis (Gogolev et al. 1989a). 
The kinetics of reaction (53) was investigated from the decrease in optical density at $600 \mathrm{~nm}$ (the peak of the optical absorption band of $\mathrm{CO}_{3}^{-}$). It was suggested that the value of $\mathrm{k}_{53}$ is comparable to or lower than the value of $k_{31}$. Thus, the concentration of $\mathrm{Np}(\mathrm{VI})$ should be sufficiently high for the observation of reaction (53), and at the same time it should also ensure the condition $k_{33}\left[\mathrm{CO}_{3}^{2-}\right]>>\mathrm{k}_{31}[\mathrm{~Np}(\mathrm{VI})]$. For instance, in $0.1 \mathrm{M} \mathrm{NaOH}$, $\mathrm{k}_{33}=5 \times 10^{7} \mathrm{M}^{-1} \mathrm{~s}^{-1}$ (see above consideration) and $\mathrm{k}_{31}=3 \times 10^{7} \mathrm{M}^{-1} \mathrm{~s}^{-1}$ (Weeks and Rabani 1966). At $0.05 \mathrm{M} \mathrm{Na}_{2} \mathrm{CO}_{3}$ and $2 \times 10^{-3} \mathrm{M} \mathrm{Np}(\mathrm{VI})$, it is possible to neglect reaction (31).

The species $e_{\mathrm{aq}}^{-}$was scavenged by $0.1 \mathrm{M} \mathrm{K}_{2} \mathrm{~S}_{2} \mathrm{O}_{8}$. Saturation of a solution with $\mathrm{N}_{2} \mathrm{O}$ was used to suppress reaction (31).

Studies showed that the presence of $2.5 \times 10^{-3} \mathrm{M} \mathrm{Np}(\mathrm{VI})$ in a solution containing $0.5 \mathrm{M} \mathrm{Na}_{2} \mathrm{CO}_{3}, 0.5$ to $1.0 \mathrm{M} \mathrm{NaOH}$, and $0.1 \mathrm{M} \mathrm{K}_{2} \mathrm{~S}_{2} \mathrm{O}_{8}$ and saturated with $\mathrm{N}_{2} \mathrm{O}$ accelerates the decay of $\mathrm{CO}_{3}^{-}$. The reactions (17) to (20), (30), (35), (42), (43), (54), and (55) occur in the solution immediately after the pulse:

$$
\begin{gathered}
\mathrm{SO}_{4}^{-}+\mathrm{CO}_{3}^{2-} \rightarrow \mathrm{SO}_{4}^{2-}+\mathrm{CO}_{3}^{-} \\
\mathrm{Np}(\mathrm{VI})+\mathrm{SO}_{4}^{-} \rightarrow \mathrm{Np}(\mathrm{VII})+\mathrm{SO}_{4}^{2-}
\end{gathered}
$$

The rate constant of reaction (43) is $7.3 \times 10^{7} \mathrm{M}^{-1} \mathrm{~s}^{-1}$ (Chalwa and Fessenden 1975); the value of $\mathrm{k}_{55}$ is unknown. Even if $\mathrm{k}_{55}$ were as high as $10^{7}$ to $10^{8} \mathrm{M}^{-1} \mathrm{~s}^{-1}$, it is possible to neglect reaction (55) because the $\mathrm{OH}^{-}$concentration is three orders of magnitude higher than the $\mathrm{Np}(\mathrm{VI})$ concentration. Therefore, $\mathrm{OH}, \mathrm{e}_{\mathrm{aq}}^{-}$, and $\mathrm{H}$ are converted to the $\mathrm{CO}_{3}^{-}$radical ion.

In the presence of $\mathrm{Np}(\mathrm{VI})$, the rate of decreasing $\mathrm{CO}_{3}^{-}$optical absorption follows the first-order law; in the absence of $\mathrm{Np}(\mathrm{VI})$, the $\mathrm{CO}_{3}^{-}$radical ions decay according to a second-order reaction

$$
\mathrm{CO}_{3}^{-}+\mathrm{CO}_{3}^{-} \rightarrow \text { Products }
$$

Treatment of the experimental data using an equation similar to equation (51) gives the value $k_{53}$ of $(9.0 \pm 1.5) \times 10^{5} \mathrm{M}^{-1} \mathrm{~s}^{-1}$. In carbonate solutions with lower alkali concentration, where the solubility of $\mathrm{Np}(\mathrm{VI})$ is lower, the same values of $\mathrm{k}_{53}$ were obtained.

In carbonate solutions containing $\mathrm{K}_{2} \mathrm{~S}_{2} \mathrm{O}_{8}$ and $\mathrm{N}_{2} \mathrm{O}$, the presence of $\mathrm{Np}(\mathrm{VI})$ has no effect on the kinetics of the $\mathrm{CO}_{3}^{-}$decay, i.e., reaction (53) does not occur. The absence of $\mathrm{Np}(\mathrm{VI})$ oxidation in carbonate solution is explained by the high potential of the $\mathrm{Np}$ (VII)/(VI) pair and also by the fact that $\mathrm{Np}(\mathrm{VI})$ under these conditions exists in the relatively stable $\mathrm{NpO}_{2}\left(\mathrm{CO}_{3}\right)_{3}^{4-}$ 
form. The ion $\mathrm{NpO}_{4}\left(\mathrm{H}_{2} \mathrm{O}\right)_{2}^{2-}$ appears upon the addition of alkali, and the radical ion $\mathrm{CO}_{3}^{-}$ reacts with this form. Probably, the oxidation process consists in the electron transfer from $\mathrm{Np}(\mathrm{VI})$ to $\mathrm{CO}_{3}^{-}$.

The reaction

$$
\mathrm{Np}(\mathrm{V})+\mathrm{CO}_{3}^{-} \rightarrow \mathrm{Np}(\mathrm{VI})+\mathrm{CO}_{3}^{2-}
$$

was also studied in carbonate-alkaline solutions via the decrease in optical density at $600 \mathrm{~nm}$. The measured values of $\mathrm{k}_{57}$ are presented in Table 5-11. The moderate increase in the rate constant with increasing alkali concentration is connected with the decrease in the potential of the $\mathrm{Np}(\mathrm{VI}) /(\mathrm{V})$ pair upon the transition from 0.2 to $1.0 \mathrm{M}$ solution of $\mathrm{NaOH}$ (Simakin and Matyashchuk 1973).

Table 5-11. The Rate Constants of Reaction Between $\mathrm{Np}(\mathrm{V})$ and $\mathrm{CO}_{3}^{-}$.

\begin{tabular}{|c|c|c|}
\hline$[\mathrm{NaOH}], \mathrm{M}$ & {$\left[\mathrm{Na}_{2} \mathrm{CO}_{3}\right], \mathrm{M}$} & $\mathrm{k}_{57} \times 10^{-7}, \mathrm{M}^{-1} \mathrm{~s}^{-1}$ \\
\hline 0.2 & 0.5 & 1.8 \\
\hline 0.5 & 0.5 & 2.4 \\
\hline 1.0 & 0.5 & 4.4 \\
\hline
\end{tabular}

5.1.2.5 Kinetics of Reaction of $\mathrm{Np}(\mathrm{VII})$ with $\mathrm{Np}(\mathrm{V})$. The optical absorption of $\mathrm{Np}$ (VII) decreases within 50 microseconds after the pulse (Pikaev and Shilov 1978). The decrease probably is because of the reaction

$$
\mathrm{Np}(\mathrm{VII})+\mathrm{Np}(\mathrm{V}) \rightarrow 2 \mathrm{~Np}(\mathrm{VI})
$$

Neptunium(V) is formed in reactions (26) and (36) and also in reactions (20), (59), and (60):

$$
\begin{gathered}
\mathrm{Np}(\mathrm{VI})+\mathrm{HO}_{2}^{-} \rightarrow \mathrm{Np}(\mathrm{V})+\mathrm{O}_{2}^{-}+\mathrm{H}^{+} \\
\mathrm{Np}(\mathrm{VI})+\mathrm{O}_{2}^{-} \rightarrow \mathrm{Np}(\mathrm{V})+\mathrm{O}_{2}
\end{gathered}
$$

Hydrogen peroxide can react with $\mathrm{Np}(\mathrm{VII})$. However, initially the $\mathrm{Np}(\mathrm{VI})$ concentration greatly exceeds $\mathrm{Np}$ (VII) concentration; when a sufficient amount of $\mathrm{Np}(\mathrm{VII})$ is accumulated, $\mathrm{H}_{2} \mathrm{O}_{2}$ is already consumed in reactions (59) and (60). 
The total yield of $\mathrm{Np}(\mathrm{V})$ is comparable with the yield of $\mathrm{Np}(\mathrm{VII})$; because of it the coordinates $1 / \mathrm{D}$ vs. time were used for the determination of reduction rate law. It was found that the experimental points lie satisfactorily on a straight line in these coordinates. Hence, the reaction rate is second order; first order each in $\mathrm{Np}(\mathrm{VII})$ and $\mathrm{Np}(\mathrm{V})$. The $\mathrm{k}_{58}$ values were calculated by the known equation

$$
\mathrm{k}_{58}=\varepsilon \mathrm{b} \tan (\varphi)
$$

where $\epsilon$ is the molar extinction coefficient of $N p(V I I), b$ is the length of the light path, and $\tan (\varphi)$ is the tangent of the slope of the straight line in coordinates $1 / \mathrm{D}$ vs. time. The resulting values are shown in Table 5-12.

Unlike the situation in solutions of $\mathrm{LiOH}$, the optical absorption connected with $\mathrm{Np}$ (VII) in solutions of $\mathrm{NaOH}$ does not decay in the period 2 to $3 \mathrm{~ms}$ after the pulse. However, the solution after the experiment was colorless. Hence, in solutions of $\mathrm{NaOH}, \mathrm{Np}$ (VII) reacts with $\mathrm{Np}(\mathrm{V})$ slower than in the solutions of LiOH. This feature seems to be caused by the different forms of $\mathrm{Np}(\mathrm{VII})$ and $\mathrm{Np}(\mathrm{V})$ which exist in the solutions of $\mathrm{NaOH}$ and $\mathrm{LiOH}$.

\section{$5.2 \gamma$-RADIOLYSIS OF ALKALINE SOLUTIONS OF NEPTUNIUM AND PLUTONIUM IONS}

Studies performed on radiolysis of solutions of actinide ions showed that the pathways of radiolytic conversions considerably depend on the irradiation conditions. By choosing the radiolytic source, it is possible to conduct oxidation or reduction of actinide ions in different valent states. This selectivity is illustrated by the development of the radiation-chemical method of preparation of $\mathrm{Np}(\mathrm{VII})$ and $\mathrm{Pu}(\mathrm{VII})$.

\subsubsection{Radiation-Induced Oxidation of $\mathrm{Np}$ (VI) Ions in Alkaline Solutions}

The radiation-chemical method of the preparation of $\mathrm{Np}$ (VII) was described shortly after the discovery of $\mathrm{Np}$ (VII) (Pikaev et al. 1969). To conduct the preparation, a $2 \times 10^{-4} \mathrm{M}$ solution of $\mathrm{Np}$ (VI) perchlorate in $1 \mathrm{M} \mathrm{NaOH}$ was saturated with $\mathrm{N}_{2} \mathrm{O}$ and irradiated with ${ }^{60} \mathrm{Co} \gamma$-rays. The formation of $\mathrm{Np}$ (VII) taking place as a result of irradiation was monitored spectrophotometrically. Later the process was studied in more detail (Pikaev et al. 1970; Pikaev et al. 1980).

Studies showed that the oxidation of $\mathrm{Np}(\mathrm{VI})$ occurs only in alkaline solutions saturated with $\mathrm{N}_{2} \mathrm{O}$. In alkaline solutions containing air or saturated with argon, $\mathrm{Np}$ (VII) is not formed. The addition of $0.1 \mathrm{M} \mathrm{NO}_{3}^{-}$ions completely suppresses $\mathrm{Np}(\mathrm{VI})$ oxidation. Similar attempts to prepare $\mathrm{Np}$ (VII) in neutral and slightly-acid (around $\mathrm{pH} 4$ ) media were unsuccessful. 
From the dependence of the concentration of $\mathrm{Np}$ (VII) product on absorbed dose for a $2.1 \times 10^{-4} \mathrm{M}$ solution of $\mathrm{Np}(\mathrm{VI})$ in $1 \mathrm{M} \mathrm{NaOH}$ saturated with $\mathrm{N}_{2} \mathrm{O}$, it was found that practically complete conversion of $\mathrm{Np}$ (VI) to $\mathrm{Np}$ (VII) occurs at doses of (5 to 6.5) x $10^{2} \mathrm{~Gy}$ (dose rate $2.8 \mathrm{~Gy} \mathrm{~s}^{-1}$ ).

One feature of the process is the presence of a short induction period. The most probable reason for the induction period is the presence of impurities in the solutions used. The impurities can compete with $\mathrm{Np}(\mathrm{VI})$ for $\mathrm{O}^{-}$radical ions formed upon water decomposition.

Table 5-12. The Rate Constants of Reaction Between

$\mathrm{Np}$ (VII) and $\mathrm{Np}(\mathrm{V})$.

\begin{tabular}{|c|c|c|}
\hline $\begin{array}{c}{[\mathrm{LiOH}],} \\
\mathrm{M}\end{array}$ & {$[\mathrm{Np}(\mathrm{VI})] \times 10^{3}, \mathrm{M}$} & $\mathrm{k}_{58} \times 10^{-7} \mathrm{M}^{-1} \mathrm{~s}^{-1}$ \\
\hline 2.0 & 9.4 & 2.0 \\
\hline 1.03 & 9.4 & 1.6 \\
\hline 0.24 & 8.1 & 1.4 \\
\hline 0.072 & 5.4 & 2.7 \\
\hline 0.033 & 4.1 & 2.5 \\
\hline
\end{tabular}

Taking into account the induction period, the initial yield of $\mathrm{Np}$ (VII) is 5.1 ions $/ 100 \mathrm{eV}$. The yield does not depend upon the Np(VI) concentration within the range of ( 2 to 5) $\times 10^{-4} \mathrm{M}$. In more dilute solutions, the yield decreases somewhat. The concentration of $\mathrm{NaOH}$ within the range of 1 to $3 \mathrm{M}$ affects the radiation-induced formation of $\mathrm{Np}$ (VII) slightly. At lower and higher concentrations of alkali, G[Np(VII)] decreases noticeably. An eight-fold decrease in dose rate does not change G[Np(VII)].

At low absorbed doses, reactions (17) to (20), (48), (31), (26), (40), (58) to (60), (62) and (63)

$$
\begin{gathered}
\mathrm{Np}(\mathrm{VII})+\mathrm{HO}_{2}^{-} \rightarrow \mathrm{Np}(\mathrm{VI})+\mathrm{H}^{+}+\mathrm{O}_{2}^{-} \\
\mathrm{Np}(\mathrm{VII})+\mathrm{O}_{2}^{-} \rightarrow \mathrm{Np}(\mathrm{VI})+\mathrm{O}_{2}
\end{gathered}
$$

occur in the system, i.e., the $\mathrm{O}^{-}$radical ion oxidizes $\mathrm{Np}(\mathrm{VI})$. Reaction (32) begins to compete with reaction (31) upon the accumulation of $\mathrm{Np}$ (VII) and the appearance of $\mathrm{O}_{2}$ in the solutions as a result of reactions (60) and (63). It is useful to compare the contributions of reactions (31) and (32). The contributions are proportional to $\mathrm{k}_{31}[\mathrm{~Np}(\mathrm{VI})]$ and $\mathrm{k}_{32}\left[\mathrm{O}_{2}\right]$, respectively. Taking into account the yields of $\mathrm{Np}$ (VII) and $\mathrm{O}_{2}(5.1$ and 0.75 molecule $/ 100 \mathrm{eV}$, respectively), then the concentration of $\mathrm{O}_{2}$ to the time required for the formation of about $5 \times 10^{-5} \mathrm{M} \mathrm{Np}(\mathrm{VII})$ is about $7 \times 10^{-6} \mathrm{M}$. Using values of $\mathrm{k}_{31}$ and $\mathrm{k}_{32}$ 
equal to $5 \times 10^{7}$ (Pikaev and Shilov 1978) and $4 \times 10^{9} \mathrm{M}^{-1} \mathrm{~s}^{-1}$ (Pikaev and Kabakchi 1982), respectively, it is found that more than $70 \%$ of the $\mathrm{O}^{-}$radical ions are consumed in reaction (32). The coincidence of experimental and calculated

$$
\left(\mathrm{G}[\mathrm{Np}(\mathrm{VII})]=\mathrm{G}_{\mathrm{OH}}+\mathrm{G}_{\mathrm{e}_{\mathrm{in}}}+\mathrm{G}_{\mathrm{H}}-2 \mathrm{G}_{\mathrm{H}_{2} \mathrm{O}_{2}}=5.0 \mathrm{ion} / 100 \mathrm{eV}\right)
$$

yields of $\mathrm{Np}$ (VII) leads to the conclusion that at $2 \times 10^{-4} \mathrm{M} \mathrm{Np}$ (VI) and at about $22{ }^{\circ} \mathrm{C}$, all the $\mathrm{O}^{-}$and $\mathrm{O}_{3}^{-}$radical ions take part in reaction (49).

The dependence of the Np(VII) yield on dose is linear up to the accumulation of $1 \times 10^{-4} \mathrm{M} \mathrm{Np}$ (VII). From that point, a deviation from linearity is observed. For the segment where $(1.2$ to 0.4$) \times 10^{-4} \mathrm{M} \mathrm{Np}(\mathrm{VI})$ remains, $\mathrm{G}[\mathrm{Np}(\mathrm{VII})]=4.0 \mathrm{ion} / 100 \mathrm{eV}$. The decrease in $\mathrm{Np}$ (VII) yield is due to side-reactions of $\mathrm{O}_{3}^{-}$.

The decrease in G[Np(VII)] at less than $1 \mathrm{M} \mathrm{NaOH}$ is explained by the acceleration of $\mathrm{O}_{3}^{-}$ decay (Gogolev et al. 1989b). The diminution of G[Np(VII)] in solutions with 3 to $5 \mathrm{M}$ $\mathrm{NaOH}$ is attributed to the same cause as the induction period noted for the $\mathrm{Np}$ (VI) oxidation, i.e., impurities. It is possible also that the decrease in the solubility of $\mathrm{N}_{2} \mathrm{O}$ [it can cause the incomplete participation of $\mathrm{e}_{\mathrm{aq}}^{-}$in reaction (30)] contributes to the diminution of the yield. Besides, it is also possible that in strongly-alkaline solutions, the life-time of $\mathrm{N}_{2} \mathrm{O}^{-}$(it is an intermediate product of reaction between $\mathrm{e}_{\mathrm{aq}}^{-}$and $\mathrm{N}_{2} \mathrm{O}$ ) increases, so that it can take part to some extent in the reaction with $\mathrm{Np}(\mathrm{VI})$ :

$$
\mathrm{Np}(\mathrm{VI})+\mathrm{N}_{2} \mathrm{O}^{-} \rightarrow \mathrm{Np}(\mathrm{V})+\mathrm{N}_{2} \mathrm{O}
$$

This reaction leads to a decrease in the G[Np(VII)].

\subsubsection{Radiation-Induced Reduction of $\mathrm{Np}$ (VII) Ions in Alkaline Solutions}

Neptunium(VI) is formed upon irradiation of aerated alkaline solutions of $\mathrm{Np}$ (VII). The respective data for a $4.3 \times 10^{-4} \mathrm{M}$ solution of $\mathrm{Np}(\mathrm{VII})$ in $2 \mathrm{M} \mathrm{NaOH}$ show that a linear dependence of $\mathrm{Np}$ (VII) reduction on the concentration of $\mathrm{Np}$ (VII) is observed at doses higher than about 300 Gy (Pikaev et al. 1970). For this part of the dependence, G[-Np(VII)] is $2.4 \mathrm{ion} / 100 \mathrm{eV}$.

The most likely mechanism of Np(VII) reduction at doses higher than 320 Gy includes reactions (17) to (20), (25), (26), (31), (41), (48), (49), (58) to (60), (62), (63), and (65)

$$
\mathrm{H}+\mathrm{O}_{2} \rightarrow \mathrm{HO}_{2}
$$


On the basis of the proposed mechanism it is possible to obtain the following equation:

$$
\mathrm{G}[-\mathrm{Np}(\mathrm{VII})]=\mathrm{G}_{\mathrm{e}_{\overline{\mathrm{n}}}}+\mathrm{G}_{\mathrm{H}}+2 \mathrm{G}_{\mathrm{H}_{2} \mathrm{O}_{2}}-\mathrm{G}_{\mathrm{OH}}
$$

The use of known values for the yields of primary products of water radiolysis indicates that G[-Np(VII)] should be $2.2 \mathrm{ion} / 100 \mathrm{eV}$, i.e. the experimental and calculated values coincide.

At low doses, when the $\mathrm{Np}(\mathrm{VI})$ concentration is small, the side reactions of $\mathrm{O}_{3}^{-}$giving rise to the formation of $\mathrm{HO}_{2}^{-}$and $\mathrm{O}_{2}^{-}$compete with reaction (49). The by-products, $\mathrm{HO}_{2}^{-}$and $\mathrm{O}_{2}^{-}$, reduce an additional amount of $\mathrm{Np}$ (VII) leading to a higher value of G[-Np(VII)].

Additional experiments on radiation-induced reduction of $\mathrm{Np}(\mathrm{VII})$ in aerated alkaline solutions showed that the yield of this process depends on the alkali concentration (Pikaev et al. 1983):

$$
\begin{array}{ccccc}
{[\mathrm{NaOH}], \mathrm{M}} & 0.22 & 0.50 & 1.0 & 2.0 \\
\mathrm{G}[-\mathrm{Np}(\mathrm{VII})], \text { ion/100 eV } & 3.1 & 2.4 & 2.2 & 2.1
\end{array}
$$

The possible reason for the increase in the value of $\mathrm{G}[-\mathrm{Np}(\mathrm{VII})]$ is the acceleration of the $\mathrm{O}_{3}^{-}$ decay with the formation of the $\mathrm{O}_{2}^{-}$radical ion in diluted alkaline solutions.

\subsubsection{Radiation-Induced Oxidation of $\mathrm{Np}$ (VI) in Alkaline \\ Solutions Containing Persulfate, Periodate, Hypobromite, or Perbromate}

In addition to $\mathrm{N}_{2} \mathrm{O}$, scavengers of $\mathrm{e}_{\mathrm{aq}}^{-}$include $\mathrm{S}_{2} \mathrm{O}_{8}^{2-}, \mathrm{H}_{3} \mathrm{IO}_{6}^{2-}, \mathrm{BrO}^{-}$and $\mathrm{BrO}_{4}^{-}$. Although $\mathrm{Np}(\mathrm{VI})$ is oxidized by the first three of these ions even without irradiation, the process proceeds effectively only at temperatures higher than $50^{\circ} \mathrm{C}$ and in solutions with high concentrations of oxidizing agent (Krot et al. 1977).

Experiments showed that irradiation (dose rate $3.2 \mathrm{~Gy} \mathrm{~s}^{-1}$ ) of aerated alkaline $2.1 \times 10^{-4} \mathrm{M}$ solutions of $\mathrm{Np}(\mathrm{VI})$ containing $0.02 \mathrm{M} \mathrm{K}_{2} \mathrm{~S}_{2} \mathrm{O}_{8}$ leads to the formation of $\mathrm{Np}$ (VII) (Shilov et al. 1979). The initial yield of $\mathrm{Np}$ (VII) was determined from the dependence of its concentration on dose. As in the case of irradiation of the solutions saturated with $\mathrm{N}_{2} \mathrm{O}$, a short induction period was observed. It is caused by the impurities present in the alkali solution. The results obtained at different alkali concentrations are shown in Table 5-13. The yield increases with increasing alkali concentration and reaches $4.5 \mathrm{ion} / 100 \mathrm{eV}$ for $2 \mathrm{M} \mathrm{NaOH}$. 
The values of the yield may be calculated on the basis of the mechanism involving reactions (17) to $(20),(26),(31),(32),(41),(42),(48),(49),(58)$ to $(60),(62),(63)$, and (65). For this mechanism

$$
\begin{gathered}
\mathrm{G}[\mathrm{Np}(\mathrm{VII})]=\mathrm{G}_{\mathrm{OH}}+\mathrm{B}\left(\mathrm{G}_{\mathrm{e}_{\mathrm{s}}^{-}}+\mathrm{AG_{ \textrm {H } }}\right)- \\
(1-\mathrm{B})\left(\mathrm{G}_{\mathrm{e}_{\mathrm{m}}^{-}}+A \mathrm{G}_{\mathrm{H}}\right)-(1-\mathrm{A}) \mathrm{G}_{\mathrm{H}}-2 \mathrm{G}_{\mathrm{H}_{2} \mathrm{O}_{2}}
\end{gathered}
$$

where

$$
\begin{aligned}
& \mathrm{A}=\mathrm{k}_{18}\left[\mathrm{OH}^{-}\right] /\left(\mathrm{k}_{18}\left[\mathrm{OH}^{-}\right]+\mathrm{k}_{65}\left[\mathrm{O}_{2}\right]\right) \text { and } \\
& \mathrm{B}=\mathrm{k}_{42}\left[\mathrm{~S}_{2} \mathrm{O}_{8}^{2-}\right] /\left(\mathrm{k}_{42}\left[\mathrm{~S}_{2} \mathrm{O}_{8}^{2-}\right]+\mathrm{k}_{26}[\mathrm{~Np}(\mathrm{VII})]+\mathrm{k}_{41}\left[\mathrm{O}_{2}\right]\right)
\end{aligned}
$$

Table 5-13. The Dependence of G[Np(VII)] on Concentration of Alkali $\left(\left[\mathrm{K}_{2} \mathrm{~S}_{2} \mathrm{O}_{8}\right]_{0}=0.02 \mathrm{M},[\mathrm{Np}(\mathrm{VI})]_{\mathrm{o}}=2.1 \times 10^{-4} \mathrm{M}\right)$.

\begin{tabular}{|c|c|c|c|c|c|}
\hline$[\mathrm{NaOH}], \mathrm{M}$ & $\begin{array}{c}\mathrm{G}[\mathrm{Np}(\mathrm{VII})], \\
\mathrm{ion} / 100 \mathrm{eV}\end{array}$ & {$\left[\mathrm{O}_{2}\right] \times 10^{4}, \mathrm{M}$} & $\mathrm{A}$ & $\mathrm{B}$ & $\begin{array}{c}\mathrm{G}[\mathrm{Np}(\mathrm{VII})]_{\text {calc, }} \\
\text { ion/100 eV }\end{array}$ \\
\hline 0.05 & 1.70 & 1.70 & 0.17 & 0.94 & 3.75 \\
\hline 0.20 & 2.10 & 2.3 & 0.48 & 0.94 & 4.06 \\
\hline 0.45 & 2.70 & 2.0 & 0.70 & 0.95 & 4.35 \\
\hline 0.50 & 2.80 & 2.0 & 0.72 & 0.95 & 4.36 \\
\hline 0.95 & 3.75 & 1.7 & 0.86 & 0.96 & 4.58 \\
\hline 1.0 & 3.85 & 1.7 & 0.86 & 0.96 & 4.58 \\
\hline 2.0 & 4.50 & 1.0 & 0.95 & 0.98 & 4.76 \\
\hline
\end{tabular}

Taking into account that $\mathrm{k}_{18}$ and $\mathrm{k}_{65}$ are equal to $2.1 \times 10^{7}$ and $2 \times 10^{10} \mathrm{M}^{-1} \mathrm{~s}^{-1} ; \mathrm{k}_{42}, \mathrm{k}_{41}$, and $\mathrm{k}_{26}$ are equal to $8 \times 10^{9}, 2 \times 10^{10}$, and $1 \times 10^{10} \mathrm{M}^{-1} \mathrm{~s}^{-1}$ (Pikaev and Kabakchi 1982); and that aerated $2 \mathrm{M} \mathrm{NaOH}$ contains $1 \times 10^{-4} \mathrm{M} \mathrm{O}_{2} ; \mathrm{A}=0.95$ and $\mathrm{B}=0.98$. Using the value of $\mathrm{G}_{\mathrm{H}_{2} \mathrm{O}_{2}}=0.75$ molecule $/ 100 \mathrm{eV}$ and the above values for yields of $\mathrm{G}_{\mathrm{OH}}, \mathrm{G}_{\mathrm{e}_{\mathrm{m}}^{-}}$, and $\mathrm{G}_{\mathrm{H}}$, $\mathrm{G}[\mathrm{Np}(\mathrm{VII})]=4.76 \mathrm{ion} / 100 \mathrm{eV}$. This yield coincides with the experimental yield (within the limits of the experimental error) for $2 \mathrm{M} \mathrm{NaOH}$. The experimental values of $\mathrm{Np}$ (VII) yield in solutions with lower concentration of alkali are less than the calculated values. The possible reason is the occurrence of $\mathrm{O}_{3}^{-}$side-reactions that are accelerated in dilute solutions of alkali.

Neptunium(VII) is also formed upon $\gamma$-irradiation of aerated alkaline solutions of Np(VI) containing $0.02 \mathrm{M}$ periodate, hypobromite, or perbromate. The initial yields of $\mathrm{Np}$ (VII) at different alkali concentrations are presented in Table 5-14. 
Table 5-14. The Influence of the Solution Composition on G[Np(VII)]

(Shilov et al. 1979 and Gusev et al. 1974).

\begin{tabular}{|c|c|c|c|c|c|c|}
\hline $\begin{array}{l}\text { Scavenger } \\
\text { (S) }\end{array}$ & $\begin{array}{c}{[\mathrm{S}] \times 10^{2},} \\
\mathrm{M}\end{array}$ & $\begin{array}{c}{[\mathrm{Np}(\mathrm{VI})]_{\mathrm{O}} \times 10^{4},} \\
\mathrm{M}\end{array}$ & $\begin{array}{c}{[\mathrm{NaOH}],} \\
\mathbf{M}\end{array}$ & $\begin{array}{c}{[\mathrm{KOH}],} \\
\mathbf{M}\end{array}$ & $\begin{array}{l}\text { G[Np(VII)], } \\
\text { ion/100 eV }\end{array}$ & $\begin{array}{c}{[\mathrm{Np}(\mathrm{VII})]_{\infty},} \\
\text { as a \% of } \\
{[\mathrm{Np}(\mathrm{VI})]_{0}}\end{array}$ \\
\hline \multirow[t]{7}{*}{$\mathrm{H}_{3} \mathrm{IO}_{6}^{2-}$} & 2 & 2.1 & 0.08 & - & 3.0 & 64 \\
\hline & 2 & 2.1 & 0.50 & - & 4.0 & 83 \\
\hline & 2 & 2.1 & 1.07 & - & 2.1 & 85 \\
\hline & 2 & 2.1 & - & 0.20 & 1.4 & 75 \\
\hline & 2 & 2.1 & - & 0.50 & 2.5 & 77 \\
\hline & 2 & 2.1 & - & 1.00 & 1.4 & 75 \\
\hline & 2 & 2.1 & - & 2.00 & 1.4 & 30 \\
\hline \multirow[t]{3}{*}{$\mathrm{BrO}^{-}$} & 2 & 3.3 & 1.0 & - & 5.3 & $\sim 100$ \\
\hline & 2 & 3.3 & 2.0 & - & 6.8 & -100 \\
\hline & 2 & 3.3 & 3.0 & - & 7.0 & -100 \\
\hline \multirow[t]{8}{*}{$\mathrm{BrO}_{4}^{-}$} & 2 & 2.2 & 0.2 & - & 2.0 & $\sim 100$ \\
\hline & 2 & 2.2 & 0.5 & - & 2.5 & $\sim 100$ \\
\hline & 2 & 2.2 & 1.1 & - & 2.9 & $\sim 100$ \\
\hline & 2 & 2.2 & 2.0 & - & 3.2 & $\sim 100$ \\
\hline & 2 & 2.2 & 3.8 & - & 3.5 & $\sim 100$ \\
\hline & 1 & 2.2 & 1.1 & - & 2.5 & $\sim 100$ \\
\hline & 4 & 2.2 & 1.1 & - & 2.7 & $\sim 100$ \\
\hline & 8 & 2.2 & 1.1 & - & 2.9 & $\sim 100$ \\
\hline
\end{tabular}

In the case of periodate, the yield value goes through a maximum in $0.5 \mathrm{M} \mathrm{NaOH}$ or $\mathrm{KOH}$. Neptunium(VI) is not oxidized completely. The observed features may be explained as follows. Reactions (16) to (20), (25), (26), (31), (41), (49), (65), and (68)

$$
\mathrm{e}_{\mathrm{aq}}^{-}+\mathrm{H}_{3} \mathrm{IO}_{6}^{2-} \rightarrow \mathrm{I}(\mathrm{VI}) \rightarrow \mathrm{IO}_{3}^{-}+\mathrm{O}^{-}+\mathrm{H}_{2} \mathrm{O}+\mathrm{OH}^{-}
$$


occur upon $\gamma$-irradiation of the solution containing periodate. Radical ion $\mathrm{O}^{-}$reacts with $\mathrm{O}_{2}$ [reaction (32)] and with I(VII):

$$
\mathrm{O}^{-}+\mathrm{H}_{3} \mathrm{IO}_{6}^{2-} \rightarrow \mathrm{IO}_{4}+3 \mathrm{OH}^{-}
$$

The species $\mathrm{IO}_{4}$ forms a complex with $\mathrm{I}(\mathrm{VII})$; the complex decays to $\mathrm{I}(\mathrm{V}), \mathrm{I}(\mathrm{VII})$, and $\mathrm{O}_{2}$ (Kläning and Sehested 1978). It is not excluded that reducing agents are present among the products of the $\mathrm{IO}_{4}$ decay. Probably, $\mathrm{I}(\mathrm{VI})$ and $\mathrm{IO}_{4}$ are able to oxidize $\mathrm{Np}(\mathrm{VI})$, for example, via reaction:

$$
\mathrm{Np}(\mathrm{VI})+\mathrm{I}(\mathrm{VI}) \rightarrow \mathrm{Np}(\mathrm{VII})+\mathrm{I}(\mathrm{V})
$$

The nature of the alkali and its concentration have an effect on the form of I(VII) existence and, as a consequence, on reaction (69), and on the conversion of $\mathrm{IO}_{4}$.

In the presence of $\mathrm{BrO}^{-}$, the oxidation of $\mathrm{Np}(\mathrm{VI})$ also occurs at less than $1 \mathrm{M} \mathrm{NaOH}$. In such solutions, part of $\mathrm{Np}(\mathrm{VI})$ coagulates after irradiation, but $\mathrm{Np}(\mathrm{VII})$ is not precipitated.

From Table 5-14 it follows that in solutions containing $\mathrm{BrO}^{-}$, the yields of $\mathrm{Np}$ (VII) are considerably higher than in solutions containing other $\mathrm{e}_{\mathrm{aq}}^{-}$scavengers. It is possible to explain this observation by the occurrence of reactions:

$$
\begin{gathered}
\mathrm{e}_{\mathrm{aq}}^{-}+\mathrm{BrO}^{-} \rightarrow \mathrm{BrO}^{2-} \rightarrow \mathrm{Br}^{-}+\mathrm{O}^{-} \\
\mathrm{HO}_{2}^{-}+\mathrm{BrO}^{-} \rightarrow \mathrm{Br}^{-}+\mathrm{O}_{2}+\mathrm{OH}^{-} \\
\mathrm{O}_{2}^{-}+\mathrm{BrO}^{-} \rightarrow \mathrm{Br}^{-}+\mathrm{O}_{2}+\mathrm{O}^{-} \\
\mathrm{H}+\mathrm{BrO}^{-} \rightarrow \mathrm{Br}^{-}+\mathrm{OH}
\end{gathered}
$$

and also reactions of $\mathrm{O}^{-}$with $\mathrm{O}_{2}$ and $\mathrm{BrO}^{-}$:

$$
\mathrm{O}^{-}+\mathrm{BrO}^{-} \rightarrow \text { Products }(\mathrm{P})
$$


The rate constant of reaction (75) at pH 12 to 13 is $3.2 \times 10^{9} \mathrm{M}^{-1} \mathrm{~s}^{-1}$ (Pikaev and Kabakchi 1982); because of it, the oxidizing agent for $\mathrm{Np}(\mathrm{VI})$ is not $\mathrm{O}_{3}^{-}$but $\mathrm{P}$, since the $\mathrm{BrO}^{-}$ concentration greatly exceeds the concentration of $\mathrm{O}_{2}$ :

$$
P+N p(V I) \rightarrow P_{1}+N p(V I I)
$$

Neptunium(V) formed in reaction (26) is oxidized by hypobromite. Thus, the yield of Np(VII) should be:

$$
\mathrm{G}[\mathrm{Np}(\mathrm{VII})]=\mathrm{G}_{\mathrm{e}_{\mathrm{e}}^{-}}+\mathrm{G}_{\mathrm{OH}}+\mathrm{G}_{\mathrm{H}}
$$

i.e., $6.5 \mathrm{ion} / 100 \mathrm{eV}$. The decrease in the G[Np(VII)] yield in $1 \mathrm{M} \mathrm{NaOH}$ is due to side reactions or to the deceleration of reaction (72).

Perbromate reacts with $\mathrm{e}_{\mathrm{aq}}^{-}$with a high rate $\left(\mathrm{k}=7 \times 10^{9} \mathrm{M}^{-1} \mathrm{~s}^{-1}\right.$ at $\left.\mathrm{pH} 7\right)$. The radical ion $\mathrm{O}^{-}$ and $\mathrm{BrO}_{3}^{-}$are formed in this reaction:

$$
\mathrm{e}_{\mathrm{aq}}^{-}+\mathrm{BrO}_{4}^{-} \rightarrow \mathrm{BrO}_{4}^{2-} \rightarrow \mathrm{BrO}_{3}^{-}+\mathrm{O}^{-}
$$

If hydrated electrons in the presence of either $\mathrm{BrO}_{4}^{-}$and $\mathrm{S}_{2} \mathrm{O}_{8}^{2-}$ are converted predominantly to $\mathrm{O}^{-}$radical ions, then the yields of $\mathrm{Np}$ (VII) in these systems should be close. This result is observed in $0.2 \mathrm{M} \mathrm{NaOH}$. The yield of $\mathrm{Np}$ (VII) in the presence of $\mathrm{BrO}_{4}^{-}$increases with increasing alkali concentration at a slower rate than in the presence of $\mathrm{S}_{2} \mathrm{O}_{8}^{2-}$. The reason is not clear. It is only possible to suggest that $\mathrm{BrO}_{4}^{-}$is decomposed partially with the formation of some reducing agents, and the decomposition depends on the $\mathrm{NaOH}$ concentration. It is not excluded that the decrease in the yield is connected with the reaction of the intermediate species $\mathrm{BrO}_{4}^{2-}$ with $\mathrm{Np}(\mathrm{VI})$ and $\mathrm{Np}(\mathrm{VII})$.

\subsubsection{Radiolysis of Carbonate-Alkaline Solutions of $\mathrm{Np}$ (VI)}

$\gamma$-Irradiation of bicarbonate and carbonate solutions of $2.4 \times 10^{-4} \mathrm{M} \mathrm{Np}(\mathrm{VI})$ saturated with $\mathrm{N}_{2} \mathrm{O}$ and also solutions containing $0.1 \mathrm{M} \mathrm{K}_{2} \mathrm{~S}_{2} \mathrm{O}_{8}$ does not lead to the formation of $\mathrm{Np}$ (VII). A small amount of $\mathrm{Np}$ (VII) appears in $\gamma$-irradiation of $\mathrm{Np}$ (VI) solutions containing $0.5 \mathrm{M} \mathrm{Na}_{2} \mathrm{CO}_{3}$ and $0.01 \mathrm{M} \mathrm{NaOH}$. Increase in the concentration of $\mathrm{NaOH}$ to $0.02 \mathrm{M}$ leads to the formation of $3 \times 10^{-5} \mathrm{M} \mathrm{Np}$ (VII); in solutions with $0.03 \mathrm{M} \mathrm{NaOH}$, neptunium (VI) is converted to $\mathrm{Np}$ (VII) completely (Gogolev et al. 1989a).

The formation of $\mathrm{Np}$ (VII) in solutions saturated with $\mathrm{N}_{2} \mathrm{O}$ occurs without an induction period. Complete conversion of $\mathrm{Np}$ (VI) to $\mathrm{Np}$ (VII) is observed at about $600 \mathrm{~Gy}$ dose. The initial yield of $\mathrm{Np}$ (VII) increases as $\mathrm{NaOH}$ concentration increases from 0.02 to $0.1 \mathrm{M}$; the $\mathrm{Np}$ (VII) yield then decreases somewhat (see Table 5-15). 
The value of the yield can be calculated if we take into account the reactions (17) to (20), (25), (26), (30), (33), (48), (49), (53), (56), (58) to (60), (62), (63), and (79):

$$
\mathrm{O}^{-}+\mathrm{CO}_{3}^{2-} \rightarrow \mathrm{CO}_{3}^{-}+\mathrm{O}^{2-}
$$

Hence,

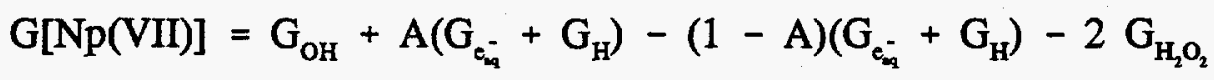

where

$$
A=k_{30}\left[\mathrm{~N}_{2} \mathrm{O}\right] /\left(\mathrm{k}_{30}\left[\mathrm{~N}_{2} \mathrm{O}\right]+\mathrm{k}_{26}[\mathrm{~Np}(\mathrm{VI})]\right)
$$

Table 5-15. The Influence of Solution Composition on $\mathrm{Np}$ (VII) Yield $\left([\mathrm{Np}(\mathrm{VI})]_{\mathrm{o}}=2.4 \times 10^{-4} \mathrm{M}\right.$, Dose Rate $\left.=9.17 \times 10^{-2} \mathrm{~Gy} \mathrm{~s}^{-1}\right)$.

\begin{tabular}{|c|c|c|}
\hline$\left[\mathrm{Na}_{2} \mathrm{CO}_{3}\right], \mathrm{M}$ & {$[\mathrm{NaOH}], \mathrm{M}$} & $\begin{array}{c}\mathrm{G}[\mathrm{Np}(\mathrm{VII})], \\
\text { ion/100 eV }\end{array}$ \\
\hline 0.50 & 0.02 & 0.7 \\
\hline 0.50 & 0.03 & 4.1 \\
\hline 0.50 & 0.10 & 4.75 \\
\hline 0.05 & 0.10 & 4.8 \\
\hline 0.50 & 0.50 & 4.35 \\
\hline 0.05 & 0.50 & 4.30 \\
\hline 0.50 & 1.0 & 4.1 \\
\hline 0.05 & 1.0 & 4.2 \\
\hline
\end{tabular}

The solubility of $\mathrm{N}_{2} \mathrm{O}$ in $1 \mathrm{M} \mathrm{KOH}$ at about $25^{\circ} \mathrm{C}$ is approximately $0.02 \mathrm{M}$ (Handbook of Chemist 1971). The solubility in a solution of $0.5 \mathrm{M} \mathrm{Na}_{2} \mathrm{CO}_{3}$ and $0.1 \mathrm{M} \mathrm{NaOH}$ is about the same level. The rate constant $k_{30}$ is $8.7 \times 10^{9} \mathrm{M}^{-1} \mathrm{~s}^{-1}$ (Pikaev and Kabakchi 1982) and $k_{27}$ is $2 \times 10^{10} \mathrm{M}^{-1} \mathrm{~s}^{-1}$ (Pikaev et al. 1974; Pikaev et al. 1973). With these data, the yield for a $2.4 \times 10^{-4} \mathrm{M}$ solution of $\mathrm{Np}(\mathrm{VI})$ is $4.8 \mathrm{ion} / 100 \mathrm{eV}$.

The coincidence of experimental and calculated yields in solutions containing 0.05 to $0.5 \mathrm{M} \mathrm{Na}_{2} \mathrm{CO}_{3}$ and $0.1 \mathrm{M} \mathrm{NaOH}$ is indicative of the small role of reaction (56). Taking into account that for $0.1 \mathrm{M} \mathrm{NaOH}, \mathrm{k}_{31}$ is $5 \times 10^{7} \mathrm{M}^{-1} \mathrm{~s}^{-1}$ (Pikaev and Shilov 1978) and 
$\mathrm{k}_{79}$ is $3 \times 10^{7} \mathrm{M}^{-1} \mathrm{~s}^{-1}$ (Weeks and Rabani 1966), we can neglect reaction (31) already at $0.05 \mathrm{M} \mathrm{Na}_{2} \mathrm{CO}_{3}$. Although $\mathrm{k}_{32}$ is $4 \times 10^{9} \mathrm{M}^{-1} \mathrm{~s}^{-1}$ (Pikaev and Kabakchi 1982), it is also possible to neglect reaction (32), since the concentration of $\mathrm{O}_{2}$ at the initial stage of the oxidation is about $10^{-5} \mathrm{M}$; because of it, $\mathrm{k}_{79}\left[\mathrm{CO}_{3}^{2-}\right]$ is much greater than $\mathrm{k}_{32}\left[\mathrm{O}_{2}\right]$. Therefore, the oxidation of $\mathrm{Np}(\mathrm{VI})$ occurs by way of reaction (53).

\subsection{5 $\gamma$-Radiolysis of Alkaline Solutions of Plutonium Ions}

Ions of $\mathrm{Pu}(\mathrm{VII})$ are formed upon $\gamma$-radiolysis of alkaline aqueous solutions of $\mathrm{Pu}(\mathrm{VI})$. The oxidation was initially observed in irradiation of alkaline solutions of $\mathrm{Pu}(\mathrm{VI})$ saturated with $\mathrm{N}_{2} \mathrm{O}$ (Pikaev et al. 1969). Later the process was studied in detail (Zakharova et al. 1971).

The source of radiation in later studies was the linear electron accelerator U-12 (Zakharova et al. 1971). The bremsstrahlung X-radiation generated by a tungsten target was utilized. The mean dose rate was about $3 \mathrm{~Gy} \mathrm{~s}^{-1}$. Since the accelerator generated the pulses with 400 $\mathrm{Hz}$ frequency (the pulse duration was $2.3 \mu \mathrm{s}$ ), the instantaneous dose rate was $3 \mathrm{kGy} \mathrm{s}^{-1}$. The maximal dose rate of the self-generated $\alpha$-radiation of ${ }^{239} \mathrm{Pu}$ (about $1.1 \times 10^{-3} \mathrm{~Gy} \mathrm{~s}^{-1}$ ) was negligible in comparison with the mean dose rate of $\mathrm{X}$-radiation.

A solution of $\mathrm{Pu}(\mathrm{VII})$ in $1 \mathrm{M} \mathrm{NaOH}$ saturated with $\mathrm{N}_{2} \mathrm{O}$ was irradiated. Preliminary determinations of the rate of auto-reduction of $\mathrm{Pu}$ (VII) (i.e. of its reaction with water) were conducted for the solutions to be used in the studies. The half-time of the auto-reduction for the $1.4 \times 10^{-3} \mathrm{M}$ solution of Pu(VII) in $1 \mathrm{M} \mathrm{NaOH}$ was 8 hours. Because of the autoreduction, experiments on radiation-induced oxidation of $\mathrm{Pu}(\mathrm{VI})$ were performed such that the interval between the beginning of irradiation and the determination of the formed Pu(VII) concentration was not longer than 10 to $12 \mathrm{~min}$. During this time, the concentration of $\mathrm{Pu}(\mathrm{VII})$ decreases by not more than 3 to $4 \%$ due to reaction with water.

It was found that $\mathrm{Pu}(\mathrm{VII})$ is formed only upon irradiation of alkaline solutions saturated with $\mathrm{N}_{2} \mathrm{O}$. For a $4.4 \times 10^{-4} \mathrm{M}$ solution of $\mathrm{Pu}(\mathrm{VI})$ in $1 \mathrm{M} \mathrm{NaOH}$, the virtually complete conversion of $\mathrm{Pu}(\mathrm{VI})$ to $\mathrm{Pu}(\mathrm{VII})$ takes place at doses of 1.2 to $1.3 \mathrm{kGy}$. As in the case of $\mathrm{Np}$ (VI) oxidation in alkaline solutions (see above consideration), a short induction period is observed. Apparently, it is due to the presence of impurities which can compete with $\mathrm{Pu}(\mathrm{VI})$ for $\mathrm{O}^{-}$radical ions formed upon water radiolysis. Taking this effect into account, the initial yield of $\mathrm{Pu}$ (VII) formation is $5.4 \mathrm{ion} / 100 \mathrm{eV}$. The yield of $\mathrm{Pu}$ (VII) does not depend on the $\mathrm{Pu}(\mathrm{VI})$ concentration within the range of $2 \times 10^{-4}$ to $1.7 \times 10^{-3} \mathrm{M}$. 
The mechanism of radiation-induced oxidation of $\mathrm{Pu}(\mathrm{VI})$ in alkaline solutions is similar to the mechanism for $\mathrm{Np}(\mathrm{VI})$. It involves reactions (17) to (20), (28) to (30), (32), (48), and (81) to (87):

$$
\begin{gathered}
\mathrm{O}^{-}+\mathrm{Pu}(\mathrm{VI}) \rightarrow \mathrm{Pu}(\mathrm{VII})+\mathrm{O}^{2-} \\
\mathrm{HO}_{2}^{-}+\mathrm{Pu}(\mathrm{VII}) \rightarrow \mathrm{Pu}(\mathrm{VI})+\mathrm{H}^{+}+\mathrm{O}_{2}^{-} \\
\mathrm{O}_{2}^{-}+\mathrm{Pu}(\mathrm{VII}) \rightarrow \mathrm{Pu}(\mathrm{VI})+\mathrm{O}_{2} \\
\mathrm{HO}_{2}^{-}+\mathrm{Pu}(\mathrm{VI}) \rightarrow \mathrm{Pu}(\mathrm{V})+\mathrm{H}^{+}+\mathrm{O}_{2}^{-} \\
\mathrm{O}_{2}^{-}+\mathrm{Pu}(\mathrm{VI}) \rightarrow \mathrm{Pu}(\mathrm{V})+\mathrm{O}_{2} \\
\mathrm{Pu}(\mathrm{VII})+\mathrm{Pu}(\mathrm{V}) \rightarrow 2 \mathrm{Pu}(\mathrm{VI}) \\
\mathrm{O}_{3}^{-}+\mathrm{Pu}(\mathrm{VI}) \rightarrow \mathrm{Pu}(\mathrm{VII})+\mathrm{O}_{2}+\mathrm{O}^{2-}
\end{gathered}
$$

For the initial part of the oxidation, it is possible to neglect reaction (28); then

$$
\begin{gathered}
\mathrm{G}[\mathrm{Pu}(\mathrm{VII})]=\mathrm{G}_{\mathrm{OH}}+\mathrm{A}\left(\mathrm{G}_{\mathrm{e}_{\mathrm{eq}}^{-}}+\mathrm{G}_{\mathrm{H}}\right)- \\
(1-\mathrm{A})\left(\mathrm{G}_{\mathrm{e}_{\mathrm{ug}}}+\mathrm{G}_{\mathrm{H}}\right)-2 \mathrm{G}_{\mathrm{H}_{2} \mathrm{O}_{2}}
\end{gathered}
$$

where

$$
\mathrm{A}=\mathrm{k}_{30}\left[\mathrm{~N}_{2} \mathrm{O}\right] /\left(\mathrm{k}_{30}\left[\mathrm{~N}_{2} \mathrm{O}\right]+\mathrm{k}_{29}[\mathrm{Pu}(\mathrm{VI})]\right) \text {. }
$$

If the concentrations of $\mathrm{N}_{2} \mathrm{O}$ and $\mathrm{Pu}(\mathrm{VI})$; the values of $\mathrm{k}_{29}$ and $\mathrm{k}_{30}$; and the values of $\mathrm{OH}, \mathrm{e}_{\mathrm{aq}}^{-}$, $\mathrm{H}$, and $\mathrm{H}_{2} \mathrm{O}_{2}$ yields (Table 5-1) are inserted into equation (88), $\mathrm{G}[\mathrm{Pu}(\mathrm{VII})]$ is found to be $4.7 \mathrm{ion} / 100 \mathrm{eV}$. The somewhat higher experimental value may be caused by using the pulse radiation as described in the original study (Zakharova et al. 1971).

The formation of $\mathrm{Pu}(\mathrm{VII})$ takes place also upon $\gamma$-radiolysis of Pu(VI) solutions in $1 \mathrm{M} \mathrm{NaOH}$ in the presence of $\mathrm{S}_{2} \mathrm{O}_{8}^{2-}$ ions (Bhattacharyya et al. 1981; Saini and Bhattacharyya 1984). It was found that G[Pu(VII)] is $4.0 \mathrm{ion} / 100 \mathrm{eV}$ at $5.1 \times 10^{-4} \mathrm{M} \mathrm{Pu}(\mathrm{VI})$ and $0.07 \mathrm{M} \mathrm{S}_{2} \mathrm{O}_{8}^{2-}$. It coincides with the $\mathrm{Np}$ (VII) yield in $1 \mathrm{M} \mathrm{NaOH}$ containing $\mathrm{S}_{2} \mathrm{O}_{8}^{2-}$ (see 
Table 5-13). As in the case of neptunium, the experimental value of Pu(VII) is lower than the calculated value; the lower value is caused by the side reactions of the $\mathrm{O}_{3}^{-}$radical ion. At a constant concentration of $\mathrm{S}_{2} \mathrm{O}_{8}^{2-}(0.025 \mathrm{M})$, the yield initially increases with increasing concentration of Pu(VI), then decreases [by as much as $2 \mathrm{ion} / 100 \mathrm{eV}$ at $5 \times 10^{-3} \mathrm{M} \mathrm{Pu}(\mathrm{VI})$ ]. The initial increase in the yield is predominantly due to the increase in the role of reaction (87), and the decrease is mainly caused by the occurrence of reaction (29) [i.e. of $e_{a q}^{-}$with $\mathrm{Pu}(\mathrm{VI})]$.

\section{3 $\alpha$-RADIOLYSIS OF AMERICIUM IONS IN CARBONATE MEDIA}

Americium(VI) in $\mathrm{NaHCO}_{3}$ or $\mathrm{Na}_{2} \mathrm{CO}_{3}$ solutions is reduced to $\mathrm{Am}(\mathrm{V})$ upon $\alpha$-irradiation. The yield for ${ }^{241} \mathrm{Am} \alpha$-particles is $4 \mathrm{ions} / 100 \mathrm{eV}$ (Coleman et al. 1963). This yield is close to the yield observed in perchloric acid solutions (Pikaev et al. 1983). The dose rate was approximately 0.05 to $0.15 \mathrm{~Gy} \mathrm{~s}^{-1}$.

However, Am(III) in carbonate solutions is oxidized to Am(IV) upon intense $\alpha$-irradiation (Osipov et al. 1977). A mixture of the radionuclides ${ }^{242} \mathrm{Cm}$ and ${ }^{244} \mathrm{Cm}$ was used as the source of $\alpha$-radiation. The experiments were carried out by the following procedure.

Hydroxides, oxalates, and nitrates of $\mathrm{Am}(\mathrm{III})$ and $\mathrm{Cm}(\mathrm{III})$ were dissolved in a concentrated solution of $\mathrm{K}_{2} \mathrm{CO}_{3}$ and stored at room temperature. The concentration of $\mathrm{K}_{2} \mathrm{CO}_{3}$ in the experimental solutions was 3 to $5.5 \mathrm{M}$, that of americium 0.02 to $0.10 \mathrm{M}$, and curium 0.04 to $0.12 \mathrm{M}$. The dose rate, mainly caused by the decay of curium, was within the range of (1 to 3$) \times 10^{2} \mathrm{~Gy} \mathrm{~s}^{-1}$.

Within a short time after the beginning of experiment (usually within one hour), the color of the solution changed from yellow-pink to brown-red. Turbidity of the solution then was observed and the formation of a precipitate took place. Over the following 20 to 30 hours, the precipitation was completed, and the brown-red color of the mother solution disappeared. The precipitate was separated and dissolved in nitric acid. Spectrophotometric measurements showed that the americium was in the pentavalent state, i.e., the precipitate was a binary carbonate of americium(V) and potassium. This conclusion was confirmed by X-ray crystal structure analysis.

High concentrations of $\mathrm{CO}_{3}^{2-}$ and Am(III) lead to the capture of $\mathrm{OH}$ radicals from spurs. As a result, $\mathrm{H}_{2} \mathrm{O}_{2}$ yield decreases. The Am(IV) was formed via reactions (33), (79), (89), and (90):

$$
\begin{gathered}
\mathrm{Am}(\mathrm{III})+\mathrm{OH} \rightarrow \mathrm{Am}(\mathrm{IV})+\mathrm{OH}^{-} \\
\mathrm{Am}(\mathrm{III})+\mathrm{CO}_{3}^{-} \rightarrow \mathrm{Am}(\mathrm{IV})+\mathrm{CO}_{3}^{2-}
\end{gathered}
$$


Americium (IV) in carbonate solutions disproportionates (Shilov and Yusov 1993):

$$
2 \mathrm{Am}(\mathrm{IV}) \rightarrow \mathrm{Am}(\mathrm{III})+\mathrm{Am}(\mathrm{V})
$$

The rate constant of the process decreases from 450 to $0.15 \mathrm{M}^{-1} \mathrm{~s}^{-1}$ by increasing the $\mathrm{K}_{2} \mathrm{CO}_{3}$ concentration from 1.5 to $5.8 \mathrm{M}$.

\section{$5.4 \alpha$-RADIOLYSIS OF PLUTONIUM HYDROXIDES IN ALKALINE MEDIA}

The behavior of $\mathrm{Pu}(\mathrm{IV})$ and $\mathrm{Pu}(\mathrm{VI})$ in 1 to $15 \mathrm{M}$ solutions of $\mathrm{NaOH}$ in experiments lasting 2 years was studied (Delegard 1987). It was found that $\mathrm{Pu}(\mathrm{V})$ accumulated over a precipitate of $\mathrm{Pu}(\mathrm{IV})$ hydroxide. With time, the concentration of $\mathrm{Pu}$ in solution decreased. The $\mathrm{Pu}(\mathrm{V})$ concentration in $1 \mathrm{M} \mathrm{NaOH}$ began to decrease in 1 to 2 days, in 2 to $9 \mathrm{M} \mathrm{NaOH}$ within 7 days, in $10 \mathrm{M} \mathrm{NaOH}$ within 20 days, and in $15 \mathrm{M} \mathrm{NaOH}$ within 56 days. The role of possible oxidizing agents was not considered (Delegard 1987); the decrease was attributed to the change in the crystallinity of $\mathrm{Pu}(\mathrm{IV})$ hydroxide.

In our opinion, two processes occurred; the oxidation of $\mathrm{Pu}(\mathrm{IV})$ on the precipitate surface and the reduction of $\mathrm{Pu}(\mathrm{V})$ in the bulk of the solution. The oxidizing agents are $\mathrm{O}_{2}$, water radiolysis products $\left(\mathrm{O}^{-}\right.$and $\left.\mathrm{HO}_{2}^{-}\right)$, and also $\mathrm{NO}_{3}^{-}$and $\mathrm{NO}_{2}^{-}$present in the solution. To consider possible $\mathrm{Pu}(\mathrm{V})$ reducing agents, the yield of $\mathrm{Pu}(\mathrm{V})$ decrease may be evaluated with the formula:

$$
\mathrm{G}[-\mathrm{Pu}(\mathrm{V})]=\mathrm{k} \frac{100}{0.693 \mathrm{~A}}
$$

where $\mathrm{k}=-2.3 \mathrm{dlog}[\mathrm{Pu}(\mathrm{V})] / \mathrm{dt}\left(\right.$ in days $\left.{ }^{-1}\right)$ and $\mathrm{A}=\Sigma \mathrm{g}_{\mathrm{i}} \mathrm{E}_{\alpha} /\left(100 \mathrm{~T}_{1 / 2}\right)$ and where $\mathrm{g}_{\mathrm{i}}$ is the percentage of the given nuclide in a mixture, $\mathrm{E}_{\alpha}$ is the energy of $\alpha$-particles, in $\mathrm{eV}$, and $\mathrm{T}_{1 / 2}$ is the half-life period in days. The A value was calculated using the values shown in Table 5-16 and was found to be 0.765 .

The initial values of $\mathrm{Pu}(\mathrm{V})_{\max }$ and $\mathrm{Pu}(\mathrm{V})$ through $\Delta t$ time (days) and the yields of $\mathrm{Pu}(\mathrm{V})$ reduction for the same solutions of $\mathrm{NaOH}(\mathrm{G}[-\mathrm{Pu}(\mathrm{V})])$ are shown in Table 5-17. It is noted that the true reduction yields will differ from the yields presented in the table, because, besides reduction, oxidation occurred. 
Table 5-16. Nuclide Composition for Plutonium Used (Delegard 1987) and Nuclide Characteristics (Gorbachev et al. 1975).

\begin{tabular}{|c|c|c|c|}
\hline $\begin{array}{c}\text { Nuclide } \\
\text { atomic mass }\end{array}$ & Percentage & $\begin{array}{c}\mathrm{T}_{1 / 2}, \\
\text { years }\end{array}$ & $\mathrm{E}_{\alpha}, \mathrm{MeV}$ \\
\hline 238 & 0.034 & 86.41 & $5.499(71.5 \%), 5.456(28.4 \%)$ \\
\hline 239 & 90.9 & $24.38 \times 10^{3}$ & $5.156(72 \%), 5.143(10.8 \%), 5.105(11.2 \%)$ \\
\hline 240 & 8.40 & $6.62 \times 10^{3}$ & $5.168(75.5 \%), 5.123(24.4 \%)$ \\
\hline 241 & 0.54 & 14 & - \\
\hline 242 & 0.11 & $3.869 \times 10^{5}$ & $4.904(75 \%), 4.859(25 \%)$ \\
\hline
\end{tabular}

The reducing agents for $\mathrm{Pu}(\mathrm{V})$ can be $\mathrm{e}_{\mathrm{aq}}^{-}, \mathrm{H}$, and $\mathrm{NO}_{3}^{2-}$. The latter species is formed in the reaction:

$$
\mathrm{e}_{\mathrm{aq}}^{-}+\mathrm{NO}_{3}^{-} \rightarrow \mathrm{NO}_{3}^{2-}
$$

In the solutions studied, $\mathrm{NO}_{3}^{-}$concentration was much greater than $0.02 \mathrm{M}$; nitrate partially captures the precursors of $\mathrm{H}_{2}$ from spurs. The high reduction yield may be caused by the fact that not only $\mathrm{Pu}(\mathrm{V})$ ions but also colloid particles of $\mathrm{Pu}(\mathrm{IV})$ and $\mathrm{Pu}(\mathrm{V})$ contribute to radiolysis.

Plutonium(VI) added to the alkaline solutions exists in ionic form and is gradually reduced. The reduction occurs as a result of radiation-induced processes. The initial yield of the $\mathrm{Pu}(\mathrm{VI})$ reduction can be evaluated from the change in the $\mathrm{Pu}(\mathrm{VI})$ concentration with time (Delegard 1987). In figure 3 of the cited report (Delegard 1987), Pu(VI) concentrations are given for solutions of different compositions through 7,35, and more days. It is interesting to note that, in the solution with $\mathrm{a}_{\mathrm{NaOH}}$ of 25 to 26 (about $9 \mathrm{M} \mathrm{NaOH}$ ), the concentration of $\mathrm{Pu}(\mathrm{VI})$ did not change in the initial 7 days. The stability in solution concentration is due to either the low degree of the $\mathrm{Pu}(\mathrm{VI})$ reduction or to the high solubility of $\mathrm{Pu}(\mathrm{V})$ (for instance, owing to the formation of a peroxide complex [Musicas 1971]).

The calculation of G[-Pu(VI)] was conducted on the formula for G[-Pu(VI)]. The initial values, taken from the cited report (Delegard 1987), are shown in Table 5-18. In performing the calculation it was supposed that the initial concentration of $\mathrm{Pu}(\mathrm{VI})$ was the same in all the solutions and was about $4.4 \times 10^{-3} \mathrm{M}$. It was also assumed that $\mathrm{Pu}(\mathrm{VI})$ was the predominant oxidation state present in the solutions through 7 days. 
Table 5-17. The Influence of the $\mathrm{NaOH}$ Concentration on the Yield of the $\mathrm{Pu}(\mathrm{V})$ Reduction.

\begin{tabular}{|c|c|c|c|c|c|}
\hline $\begin{array}{c}{[\mathrm{NaOH}],} \\
\mathbf{M}\end{array}$ & $\begin{array}{c}{[\mathrm{Pu}(\mathrm{V})]_{\max },} \\
\mathbf{M}\end{array}$ & $\begin{array}{c}\Delta \mathrm{t}, \\
\text { day }\end{array}$ & $\begin{array}{c}{[\mathrm{Pu}(\mathrm{V})],} \\
\mathrm{M}\end{array}$ & $\begin{array}{c}\mathrm{k} \mathrm{x} 10^{2}, \\
\mathrm{day}^{-1}\end{array}$ & $\begin{array}{c}\mathrm{G}[-\mathrm{Pu}(\mathrm{V})], \\
\text { ion } / 100 \mathrm{eV}\end{array}$ \\
\hline 1 & $9.25 \times 10^{-8}$ & 5 & $6.12 \times 10^{-8}$ & 8.24 & 15.5 \\
\hline 2 & $3.42 \times 10^{-7}$ & 13 & $1.60 \times 10^{-7}$ & 5.84 & 11.0 \\
\hline 4 & $1.84 \times 10^{-6}$ & 13 & $0.98 \times 10^{-6}$ & 4.70 & 8.8 \\
\hline 6 & $1.0 \times 10^{-5}$ & 13 & $5.4 \times 10^{-6}$ & 4.66 & 8.8 \\
\hline 8 & $3.6 \times 10^{-5}$ & 13 & $2.38 \times 10^{-5}$ & 3.06 & 5.8 \\
\hline 10 & $1.35 \times 10^{-4}$ & 36 & $7.75 \times 10^{-5}$ & 1.54 & 2.9 \\
\hline 15 & $5.33 \times 10^{-3}$ & 96 & $1.42 \times 10^{-3}$ & 1.38 & 2.6 \\
\hline
\end{tabular}

The decrease in $\mathrm{Pu}(\mathrm{VI})$ concentration occurs as a result of reactions (29) and (81) to (87). If the yields of primary products of water $\alpha$-radiolysis in alkaline media are the same as in perchloric acid or sulphuric acid solutions, then the yield of the $\mathrm{Pu}(\mathrm{VI})$ reduction to $\mathrm{Pu}(\mathrm{V})$ should be about 3 ion $/ 100 \mathrm{eV}$ (Pikaev et al. 1983). The higher yields testify to the participation of impurities in the process. One of them is $\mathrm{NO}_{3}^{-}$. Organic compounds, introduced into the solution with distilled water, alkali, and also from the walls of polyethylene vessels in which the long-time experiments were performed, also could act as reducing agents. One more possible reason is the co-precipitation of $\mathrm{Pu}(\mathrm{VI})$ with $\mathrm{Pu}(\mathrm{V})$.

Table 5-18. Initial Yields of the Pu(VI) Reduction $\left([\mathrm{Pu}(\mathrm{VI})]_{\mathrm{o}}=4.4 \times 10^{-3} \mathrm{M}\right)$ (Delegard 1987).

\begin{tabular}{|c|c|c|c|}
\hline$a_{\mathrm{NaOH}}$ & $\begin{array}{c}{[\mathrm{Pu}(\mathrm{VI})] \times 10^{3}} \\
\text { through } 7 \text { days, } \mathrm{M}\end{array}$ & $\begin{array}{l}\mathbf{k} \times 10^{2} \\
\text { day }^{-1}\end{array}$ & $\begin{array}{l}\mathrm{G}[-\mathrm{Pu}(\mathrm{VI})] \\
\text { ion } / 100 \mathrm{eV}\end{array}$ \\
\hline 0.6 & 1.72 & 13.4 & 25.2 \\
\hline 1.3 & 2.57 & 7.7 & 14.4 \\
\hline 2.2 & 2.88 & 6.1 & 11.5 \\
\hline 3.4 & 4.00 & 1.38 & 2.6 \\
\hline
\end{tabular}


Plutonium(V) in the precipitate captures $\mathrm{e}_{\mathrm{aq}}^{-}$from spurs

$$
\mathrm{NaPuO}_{2}(\mathrm{OH})_{2} \cdot \mathrm{xH}_{2} \mathrm{O}+\mathrm{e}_{\mathrm{aq}}^{-} \rightarrow \mathrm{PuO}_{2} \cdot \mathrm{xH}_{2} \mathrm{O}+\mathrm{Na}^{+}+2 \mathrm{OH}^{-}
$$

After some period, part of the $\mathrm{Pu}(\mathrm{V})$ is converted to $\mathrm{Pu}(\mathrm{IV})$ and leads to the observed change in the color of the precipitate (Delegard 1987).

\subsection{RADIOLYSIS OF ALKALINE SOLUTIONS OF TECHNETIUM IONS}

The radiolysis of alkaline solutions of technetium ions was studied on only a fragmentary basis. There are data on the preparation of $\mathrm{Tc}(\mathrm{VI})$ ions from $\mathrm{TcO}_{4}^{-}$and the investigation of some properties of $\mathrm{Tc}(\mathrm{VI})$ ions within a wide range of $\mathrm{pH}$ values by pulse radiolysis (Pikaev et al. 1977b; Deutsch et al. 1978; Kryuchkov et al. 1979).

It was found that $\mathrm{TcO}_{4}^{2-}$ is formed in reactions (Pikaev et al. 1977b):

$$
\begin{gathered}
\mathrm{e}_{\mathrm{aq}}^{-}+\mathrm{Tc}(\mathrm{VII}) \rightarrow \mathrm{Tc}(\mathrm{VI}) \\
\mathrm{H}+\mathrm{Tc}(\mathrm{VII}) \rightarrow \mathrm{H}^{+}+\mathrm{Tc}(\mathrm{VI})
\end{gathered}
$$

The optical absorption parameters of $\mathrm{Tc}(\mathrm{VI})$ were found to depend on the $\mathrm{pH}$ value of the solution (Pikaev et al. 1977b; Kryuchkov et al. 1979) (see Table 5-19). It was proposed that this feature is due to the existence of $\mathrm{Tc}(\mathrm{VI})$ in different forms:

$$
\begin{aligned}
& \mathrm{K}_{1} \quad \mathrm{~K}_{2} \\
& \mathrm{H}_{2} \mathrm{TcO}_{4} \rightleftarrows \mathrm{HTcO}_{4}^{-}+\mathrm{H}^{+} \rightleftarrows \mathrm{TcO}_{4}^{2-}+2 \mathrm{H}^{+}
\end{aligned}
$$

The values of $\mathrm{pK}_{1}$ and $\mathrm{pK}_{2}$ were found to be $\geq-0.5$ and 8.7 , respectively (Kryuchkov et al. 1979). The pulse radiolysis method allowed measurement of several reaction rate constants occurring in the system under consideration. The respective data are shown in Table 5-20. 
Table 5-19. Molar Extinction Coefficients $(\epsilon)$ of $\mathrm{Tc}(\mathrm{VI})$ Ions in Aqueous Solutions (Pikaev et al. $1977 \mathrm{~b}$ and

Kryuchkov et al. 1979).

\begin{tabular}{|c|c|c|}
\hline Ion & Wavelength, $\mathrm{nm}$ & $\epsilon, \mathrm{M}^{-1} \mathrm{~cm}^{-1}$ \\
\hline $\mathrm{HTcO}_{4}^{-}$ & 295 & $2.6 \times 10^{3}$ \\
\hline & 360 & $6.0 \times 10^{2}$ \\
\hline & 500 & $\sim 75$ \\
\hline $\mathrm{TcO}_{4}^{2-}$ & 360 & $3.8 \times 10^{2}$ \\
\hline & 500 & $2.8 \times 10^{2}$ \\
\hline & $500-600$ & $\sim 2.5 \times 10^{2} \mathrm{a}$ \\
\hline
\end{tabular}

${ }^{\text {a } F r o m ~(D e u t s c h ~ e t ~ a l . ~ 1978) ~}$

In deaerated solutions, $\mathrm{Tc}(\mathrm{VI})$ decays by two second-order reactions and forms from disproportionation of $\mathrm{Tc}(\mathrm{V})$ :

$$
\begin{gathered}
\mathrm{OH}+\mathrm{Tc}(\mathrm{VI}) \rightarrow \mathrm{Tc}(\mathrm{VII})+\mathrm{OH}^{-} \\
\mathrm{Tc}(\mathrm{VI})+\mathrm{Tc}(\mathrm{VI}) \rightarrow \mathrm{Tc}(\mathrm{VII})+\mathrm{Tc}(\mathrm{V}) \\
\mathrm{Tc}(\mathrm{V})+\mathrm{Tc}(\mathrm{V}) \rightarrow \mathrm{Tc}(\mathrm{VI})+\mathrm{Tc}(\mathrm{IV})
\end{gathered}
$$

In solutions containing tertiary butyl alcohol (it is an effective scavenger of hydroxyl radicals), reaction (98) is suppressed, and only disproportionation of $\mathrm{Tc}(\mathrm{VI})$ occurs; the respective rate constants are given in Table 5-20. As seen from the table, the rate of $\mathrm{TcO}_{4}^{2-}$ disproportionation is less than that for the other $\mathrm{Tc}(\mathrm{VI})$ forms. The highest rate is for the reaction:

$$
\mathrm{HTcO}_{4}^{-}+\mathrm{TcO}_{4}^{2-} \rightarrow \mathrm{TcO}_{4}^{-}+\mathrm{H}^{+}+\mathrm{TcO}_{4}^{3-}
$$

which seems to be a process of simple electron transfer from $\mathrm{HTcO}_{4}^{-}$to $\mathrm{TcO}_{4}^{2-}$. Note that $\mathrm{Tc}$ (VI) in alkaline medium has a lifetime on the order of milliseconds (Deutsch et al. 1978). This observation coincides with other measurements (Kryuchkov et al. 1979). 
Table 5-20. Rate Constants of Reactions in Irradiated Solutions of $\mathrm{TcO}_{4}$.

\begin{tabular}{|c|c|c|c|}
\hline Reaction & Medium & $\mathrm{k}^{-1} \mathrm{M}^{-1}$ & Reference $^{\mathrm{a}}$ \\
\hline $\mathrm{e}_{\mathrm{aq}}^{-}+\mathrm{TcO}_{4}^{-}$ & $\begin{array}{c}\text { Neutral or } \\
\text { slightly acid }\end{array}$ & $1.3 \times 10^{10}$ & {$[1]$} \\
\hline $\mathrm{OH}+\mathrm{TcO}_{4}^{2-}$ & $\begin{array}{c}\text { Neutral or } \\
\text { slightly acid }\end{array}$ & $2.5 \times 10^{10}$ & {$[2]$} \\
\hline $\begin{array}{c}\text { Disproportionation } \\
\text { of Tc(VI) }\end{array}$ & $\mathrm{pH}<2$ & $\sim 3 \times 10^{9}$ & {$[1]$} \\
\hline & $\mathrm{pH} \sim 8$ & $3.8 \times 10^{7}$ & {$[3]$} \\
\hline & $\mathrm{pH}>9$ & $\sim 2 \times 10^{6}$ & {$[3]$} \\
\hline
\end{tabular}

${ }^{a}$ References:

[1] Pikaev et al. 1977b

[2] Deutsch et al. 1978

[3] Kryuchkov et al. 1979 


\subsection{REFERENCES}

Anbar, M. and E. J. Hart, 1965, J. Phys. Chem., 69, p. 1244.

Bhattacharyya, P. K., and R. D. Saini, 1981, Radiat. Eff. Lett., 57, p. 165.

- Burns, W. G., and H. E. Sims, 1981, J. Chem. Soc. Faraday Trans: Part I, 77, p. 2803.

Chalwa, O. P., and R. W. Fessenden, 1975, J. Phys. Chem., 79, p. 2693.

Coleman, J. S., T. K. Keenan, L. H. Jones, W. Carnall, and R. A. Penneman, 1963, Inorg. Chem. 2 , p. 58.

Delegard, C. H., 1987, Radiochimica Acta, 41, p. 11.

Deutsch, E., W. R. Heineman, R. Hurst, J. C. Sullivan, W. A. Mulac, and S. Gordon, 1978, J. Chem. Soc., Chem. Commun., p. 1038.

Fedoseev, A. M., V. F. Peretrukhin, and N. N. Krot, 1979, Dokl. Akad. Nauk SSSR, 244, p. 1187.

Gogolev, A. V., V. P. Shilov, and A. K. Pikaev, 1989a, Izv. Akad. Nauk SSSR., Ser. Khim., p. 20.

Gogolev, A. V., V. P. Shilov, A. M. Fedoseev, and A. K. Pikaev, 1990, Izv. Akad. Nauk SSSR., Ser. Khim., p. 28.

Gogolev, A. V., V. P. Shilov, and A. K. Pikaev, 1989b, Radiokhimiya, 31, p. 124.

Gopihathan, C., E. J. Hart, and K. H. Schmidt, 1970, J. Phys. Chem., 74, p. 4169.

Gorbachev, V. M., Yu. S. Zamyatin, and A. A. Lbov, 1975, Main Regularities for Isotopes of Heavy Elements, Atomizdat, Moscow, USSR, pp. 49-62 (in Russian).

Gusev, Yu. K., V. P. Shilov, and N. N. Krot, 1979, Radiokhimiya, 21, p. 923.

Handbook of Chemist, 1971, Khimiya, Moscow-Leningrad, USSR, Vol. 1, p. 623 (in Russian).

Henglein, A., 1980, Radiat. Phys. and Chem., 15, p. 151.

Kabakchi, S. A., and V. N. Shubin, 1972, Intern. J. Rad. Phys. and Chem., 4, p. 1.

Kabakchi, S. A., 1971, Khim. Vys. Energ., 5, p. 180. 
Kläning, U. K., and K. Sehested, 1978, J. Chem. Soc. Faraday Trans., Part I, 74, p. 2818.

Krot, N. N., A. D. Gel'man, M. P. Mefod'eva, V. P. Shilov, V. F. Peretrukhin, and V. I. Spitsyn, 1977, Semivalentnoe Sostoyanie Neptuniya, Plutoniya, Ameritsiya, Nauka, Moscow, USSR, (in Russian). Available in English as Heptavalent States of Neptunium, Plutonium, and Americium, UCRL-Trans-11798, Lawrence Livermore National Laboratory, Livermore, California.

Kryuchkov, S. V., A. K. Pikaev, A. F. Kuzina, and V. I. Spitsyn, 1979, Dokl. Akad. Nauk SSSR, 247, p. 1187.

Mulac, W. A., S. Gordon, K. H. Schmidt, D. W. Webster, and J. C. Sullivan, 1984, Inorg. Chem., 23, p. 1639 .

Musicas, C., 1971, Radiochem. Radioanal. Lett., 7, p. 375.

Neta, P., and R. H. Schuler, 1975, J. Phys. Chem., 79, p. 1.

Osipov, S. V., N. N. Andreichuk, V. Ya. Vasil'ev, and A. G. Rykov, 1977, Radiokhimiya, $\underline{19}$, p. 522.

Pikaev, A. K., 1986, Modern Radiation Chemistry Radiolysis of Gases and Liquids, Nauka, Moscow, USSR, (in Russian).

Pikaev, A. K., B. G. Ershov, and I. E. Makarov, 1975, J. Phys. Chem., 79, p. 3025.

Pikaev, A. K., and S. A. Kabakchi, 1982, Reactivity of Primary Products of Water Radiolysis Handbook, Energoizdat, Moscow, USSR (in Russian).

Pikaev, A. K., S. V. Kryuchkov, A. F. Kuzina, and V. I. Spitsyn, 1977b, Dokl. Akad. Nauk SSSR, 236, p. 1155 .

Pikaev, A. K., M. P. Mefod'eva, N. N. Krot, and V. I. Spitsyn, 1974, Izv. Akad. Nauk SSSR., Ser. Khim., p. 2847.

Pikaev, A. K., M. P. Mefod'eva, N. N. Krot, and V. I. Spitsyn, 1973, Khim Vys. Energ., 7, p. 505.

Pikaev, A. K., M. P. Mefod'eva, F. A. Zakharova, V. P. Shilov, N. N. Krot, A. D. Gel'man, and V. I Spitsyn, 1976, in Proceedings of the Moscow Symposium on the Chemistry of the Transuranium Elements, V. I. Spitsyn and J. J. Katz, eds., Supplement to the J. Inorganic and Nuclear Chemistry, Pergamon Press, Oxford, UK (1976), pp. 95-98.

Pikaev, A. K., and V. P. Shilov, 1978, Izv. Akad. Nauk SSSR., Ser. Khim., p. 2136. 
Pikaev, A. K., V. P. Shilov, N. N. Krot, A. D. Gel'man, and V. I. Spitsyn, 1969, Izv. Akad. Nauk SSSR., Ser. Khim., 1199.

Pikaev, A. K., V. P. Shilov, N. N. Krot, A. D., A. D. Gel'man, and V. I. Spitsyn, 1970, Dokl. Akad. Nauk SSSR, 190 , p. 387.

Pikaev, A. K., V. P. Shilov, N. N. Krot, and V. I. Spitsyn, 1980, Radiat. Phys. Chem., 15, p. 139.

Pikaev, A. K., V. P. Shilov, and V. I. Spitsyn, 1977a, Dokl. Akad. Nauk SSSR, 232, p. 387 .

Pikaev, A. K., V. P. Shilov, and V. I. Spitsyn, 1983, Radioliz Vodnyh Rastvorov Lantanidov i Aktinidov, Nauka, Moscow, USSR, (in Russian). Available in English as Radiolysis of Aqueous Solutions of Lanthanides and Actinides, 1985, AERE LBG-8501002, Atomic Energy Research Establishment, Harwell, UK.

Saini, R. D., and P. K. Bhattacharyya, 1984, Radiat. Phys. and Chem., 23, p. 509.

Shilov, V. P., N. N. Krot, and A. D. Gel'man, 1971, Radiokhimiya, 13, p. 9.

Shilov, V. P., and A. K. Pikaev, 1982, Khim. Vys. Energ., 16, p. 468.

Shilov, V. P., A. K. Pikaev, N. N. Krot, and E. S. Stepanova, 1979, Radiokhimiya, 21, p. 608.

Shilov, V. P., and A. B. Yusov, 1993, Radiokhimiya, 35, p. 61.

Simakin, G. A., and I. V. Matyashchuk, 1969, Radiokhimiya, 11, p. 481.

Simakin, G. A., and I. V. Matyashchuk, 1973, Radiokhimiya, 15, p. 98.

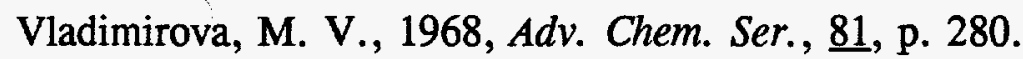

Weeks, J. L., and J. Rabani, 1966, J. Phys. Chem., 70, p. 2100.

Zachariasen, W. H., 1954, in: The Actinide Elements, G. T. Seaborg, and J. J. Katz, Eds., Nat. Nucl. En. Ser. Div IV, Vol. 14A, p. 769, McGraw-Hill, New York, New York.

Zakharova, F. A., A. K. Pikaev, M. M. Orlova, A. D. Gel'man, and V. I. Spitsyn, 1971, Dokl. Akad. Nauk SSSR, 201, p. 636.

Zhestkova, T. P., and A. K. Pikaev, 1976, Khim. Vys. Energ., 10, p. 413. 
This page intentionally left blank. 


\subsection{METHODS OF ISOLATION OF ACTINIDES AND TECHNETIUM FROM ALKALINE MEDIA WITHOUT ACIDIFICATION}

Actinides in alkaline media form solid phases and can also form colloids, pseudocolloids, molecular neutral species, and anions. Solid phases are separated by filtration and centrifugation and colloids are separated by ultrafiltration through membranes and filters with small-sized pores. Coprecipitation, sorption, extraction, and electroprecipitation are used for the separation of molecular and ionic forms.

\subsection{COPRECIPITATION}

The coprecipitation of microamounts of radionuclides, including actinides, has been applied from the first days of existence of radiochemistry and plays a comparatively important role at the present time. Hydroxides, sulfates, phosphates, carbonates, and organic compounds were used as carriers. However, the reported developments concerned acid, neutral, and sometimes carbonate media (Seaborg and Katz 1954; Katz and Seaborg 1957; Milyukova et al. 1965; Metz and Waterbury 1962; and Myasoedov et al. 1972). No published material on the coprecipitation of actinides from alkaline media was found. Nevertheless, concentrating and separating actinides from alkaline media by the coprecipitation method with use of hydroxides of d-elements has been applied in the past 20 years in the laboratory of transuranium elements of the Institute of Physical Chemistry of the Russian Academy of Sciences (the head of laboratory is Professor N. N. Krot). Although the method allows one to separate the bulk of the actinide activity, and the radioactivity level in effluent water is within the approved level for processing at a purification plant, many of the parameters of the method have not been studied. The coprecipitation of $\mathrm{Np}(\mathrm{VI}), \mathrm{Pu}(\mathrm{V})$, and $\mathrm{Am}(\mathrm{VI})$ as a function of the alkali concentration, the influence of chemical constituents such as $\mathrm{NO}_{3}^{-}, \mathrm{SO}_{4}^{2-}$, $\mathrm{CO}_{3}^{2-}$, EDTA, and $\mathrm{C}_{2} \mathrm{O}_{4}^{2-}$ on coprecipitation, and the behavior of colloids and pseudocolloids upon coprecipitation have not been studied and are unknown.

\subsection{SORPTION}

The sorption of actinides in alkaline solutions on various sorbents has been studied since the time of the discovery of heptavalent states of neptunium and plutonium. The behavior of $\mathrm{Np}$ (VII) in contact with anion exchange resins AB-17, Amberlite ${ }^{1}$ IRA-400, and Dowex- ${ }^{2}$ was studied (Novikov et al. 1972a). Equilibrium upon sorption is achieved during 25, 50 and 75 hours in the cases of IRA-400, Dowex-1x10 and Dowex-1x8, respectively. The distribution coefficient, $K_{d}$, is defined:

\footnotetext{
${ }^{1}$ Amberlite is a trademark of Rohm \& Haas, Philadelphia, Pennsylvania.

${ }^{2}$ Dowex is a trademark of Dow Chemical USA, Midland, Michigan.
} 


$$
K_{d}=\frac{\left(C_{i n}-C_{e q}\right) V}{C_{e q} m}
$$

where $\mathrm{C}_{\mathrm{in}}$ is the initial concentration of the radioactive species in solution, $\mathrm{C}_{\mathrm{eq}}$ is the equilibrium concentration, $\mathrm{V}$ is the total volume of the solution (in $\mathrm{mL}$ ), and $\mathrm{m}$ is the weight of sorbent (in $\mathrm{g}$ ). For $\mathrm{Np}(\mathrm{VII})$ at equilibrium the $\mathrm{K}_{\mathrm{d}} \mathrm{s}$ are $>2400$, about 2300, almost 1800 , about 500 and $>400$ for Dowex-1x4, AB-17, Dowex-1x8, Dowex-1x10, and IRA-400, respectively.

The highest $\mathrm{K}_{d}$ values are found in $0.1 \mathrm{M} \mathrm{NaOH}$. The $\mathrm{K}_{\mathrm{d}}$ value decreases with increasing $\mathrm{NaOH}$ concentration. The completeness of the Np sorption on the solid phase depends on the ratio of the volume of alkaline solution to the weight of the sorbent and on the nature of the sorbent. The maximum capacity with respect to neptunium is about $5.9 \times 10^{-2}$ and about $3.8 \times 10^{-2} \mathrm{~mol} \mathrm{~g}^{-1}$ for Dowex-1x4 and AB-17, respectively. Desorption of neptunium from anion exchangers by solutions of $\mathrm{NaOH}, \mathrm{NaClO}_{4}$, or their mixtures does not occur. $\mathrm{Np}$ (VII) in the desorbates was not found. The results are consistent with the hypothesis that the transition of $\mathrm{Np}(\mathrm{VII})$ into the solid phase upon long contact with organic sorbents is accompanied by the simultaneous reduction to $\mathrm{Np}(\mathrm{VI})$.

In addition to anion exchangers, cation exchanger $\mathrm{KU}-2$, active carbon, and titanium oxide were used as sorbents for $\mathrm{Np}$ (VII). All these sorbents separate $\mathrm{Np}$ (VII) from $0.1 \mathrm{M} \mathrm{NaOH}$. The $K_{d}$ value for active carbon is about $10^{3}$ (the equilibrium is established in 5 hours [Novikov et al. 1972a]). Absorption of $\mathrm{Np}(\mathrm{VII})$ on $\mathrm{TiO}_{2}$ occurs without change in $\mathrm{Np}$ valency.

Inorganic sorbents are promising for the separation of $\mathrm{Np}(\mathrm{VII})$ from alkaline solutions (Zakharova et al. 1974). Hydroxides of $\mathrm{La}, \mathrm{Th}, \mathrm{Zr}, \mathrm{Ti}$, and $\mathrm{Mg}$, and sodium uranate, which were frozen to prepare a grainy precipitate, were used as sorbents. The sorption of $\mathrm{Np}$ (VII) was studied in static and dynamic regimes.

Under static conditions, $\mathrm{Np}(\mathrm{VII})$ is adsorbed from 0.2 to $1 \mathrm{M} \mathrm{NaOH}$ on $\mathrm{La}, \mathrm{Th}$, and U(VI) hydroxides. The sorption of $\mathrm{Np}(\mathrm{VII})$ on $\mathrm{Mg}, \mathrm{Zr}, \mathrm{Ti}$, and $\mathrm{Bi}$ hydroxides is small. The sorption of $\mathrm{Np}(\mathrm{VII})$ decreases with increasing $\mathrm{NaOH}$ concentration. The $\mathrm{K}_{\mathrm{d}}$ value is the highest for $\mathrm{La}(\mathrm{OH})_{3}$ (about $10^{3}$ for $1 \mathrm{M} \mathrm{NaOH}$ and about $5 \times 10^{2}$ for $3.5 \mathrm{M} \mathrm{NaOH}$ ). The experimental data for $\mathrm{La}(\mathrm{OH})_{3}$ and $\mathrm{Th}(\mathrm{OH})_{4}$ are reproducible. In the case of uranates, the results are not reproducible. The inconsistency seems to be connected with the variable composition of the solid phase.

The sorption of $\mathrm{Np}$ (VII) by hydroxide precipitates is reversible. It is caused by the formation of poorly-soluble compounds: 


$$
\begin{gathered}
\left.\mathrm{xM}(\mathrm{OH})_{\mathrm{n}}+\mathrm{y} \mathrm{NpO} \mathrm{NOH}_{2}\right)_{2}^{3-} \rightleftarrows \\
{\left[\mathrm{M}(\mathrm{OH})_{\mathrm{n}-3 \mathrm{y}}\right]_{\mathrm{x}}\left[\mathrm{NpO}_{4}(\mathrm{OH})_{2}\right]_{\mathrm{y}}+3 \mathrm{y} \mathrm{OH}^{-}}
\end{gathered}
$$

The chemical nature of the sorbent has a large influence on the sorption of $\mathrm{Np}$ (VII). It is due to the differences in the bond strengths for $\mathrm{OH}^{-}$ions with metals in hydroxide precipitates, and in the solubilities of the formed compounds of $\mathrm{Np}$ (VII). Only negligible exclusion of $\mathrm{OH}^{-}$ions from $\mathrm{Zr}, \mathrm{Ti}$, and Bi occurs, and the sorption of $\mathrm{Np}$ (VII) is small. In the case of $\mathrm{Mg}(\mathrm{OH})_{2}$, the $\mathrm{OH}^{-}$exclusion proceeds easily, but $\mathrm{Np}(\mathrm{VII})$ does not form poorly-soluble compounds with $\mathrm{Mg}^{2+}$. Therefore $\mathrm{Np}$ (VII) sorption on $\mathrm{Mg}(\mathrm{OH})_{2}$ is also small. The most favorable relation between the ease of $\mathrm{OH}^{-}$exclusion and the solubility of the $\mathrm{Np}$ (VII) compound with sorbent takes place in the case of $\mathrm{La}(\mathrm{OH})_{3}$.

A dark-green layer with a clear interface is formed in a column upon the sorption of $\mathrm{Np}$ (VII) from 0.5 to $1 \mathrm{M} \mathrm{NaOH}$ on $\mathrm{La}(\mathrm{OH})_{3}$ or $\mathrm{Th}(\mathrm{OH})_{4}$ under dynamic conditions. The interface moves down as the sorbent becomes saturated. After complete saturation of the column, the molar ratio of $\mathrm{La}$ or $\mathrm{Th}$ to $\mathrm{Np}(\mathrm{VII})$ in the sorbent phase is close to $10: 1$.

The desorption of $\mathrm{Np}$ (VII) from the column can be conducted by $5 \mathrm{M} \mathrm{NaOH}$. Neptunium in the desorbate is only in the heptavalent state. $\mathrm{Np}$ (VII) is desorbed virtually completely after passing a sufficient amount of concentrated alkali solution through the column (for example, the $\mathrm{Th}(\mathrm{OH})_{4}$ layer contains 5 to $7 \%$ neptunium after 30 column volumes).

For the separation of $\mathrm{Np}(\mathrm{VII})$ from $\mathrm{Np}(\mathrm{VI})$ and $\mathrm{Np}(\mathrm{V})$, the solution containing neptunium and 0.5 to $1.7 \mathrm{M} \mathrm{NaOH}$ was passed through a column of aluminum oxide (the size of grains was 70-230 mesh) (Shiokawa et al. 1982). The column diameter was $0.6 \mathrm{~cm}$ and the length was $10 \mathrm{~cm}$. Upon passing the alkaline solution, greater than $98 \% \mathrm{~Np}(\mathrm{~V})$ sorption was observed with considerable sorption of $\mathrm{Np}(\mathrm{VI})$, but little $\mathrm{Np}$ (VII) sorption. The sorbed $\mathrm{Np}$ (VII) is the first that is washed from the column upon passing more alkaline solution through the column.

If the initial solution contains only $\mathrm{Np}(\mathrm{VII})$ and $\mathrm{Np}(\mathrm{VI})$, then the chromatography on aluminum oxide allows one to prepare separated samples of $\mathrm{Np}(\mathrm{VII})$ and $\mathrm{Np}(\mathrm{VI})$.

The sorption of trace amounts of plutonium and americium on sodium titanate was used for the purification of spent alkaline solutions (Schulz 1979). The solution $\alpha$-activity concentration decreases to less than 6 to $7 \mathrm{nCi} \mathrm{g}^{-1}\left(220\right.$ to $\left.260 \mathrm{~Bq} \mathrm{~g}^{-1}\right)$ as a result of slow passage of the solution through the layer of sodium titanate.

In a recent review, it was noted that inorganic sorbents are used for the separation of actinides from alkaline media and that studies in this direction are being continued (March 1993). 
Technetium in alkaline solutions exists in the form of $\mathrm{TcO}_{4}^{-}$(see Section 2.0 of this survey). In contrast with many anions, $\mathrm{TcO}_{4}^{-}$is highly sorbed on the strong base anion exchangers (Lavrukhina et al. 1966; and Spitsyn et al. 1981). The $\mathrm{K}_{\mathrm{d}}$ value for technetium sorption on the anion exchange resin Dowex-1 from $0.25 \mathrm{M} \mathrm{NaOH}$ decreases with increasing $\mathrm{NO}_{3}^{-}$ concentration (see Table 6-1).

Table 6-1. The Distribution Coefficients $\left(\mathrm{K}_{\mathrm{d}}\right)$ of $\mathrm{TcO}_{4}^{-}$Upon Sorption on the Anion Exchange Resin Dowex-1 from 0.25 M $\mathrm{NaOH}$

(Rimshaw and Malling 1961).

\begin{tabular}{|c|c|c|c|}
\hline$\left[\mathrm{NaNO}_{3}\right], \mathrm{M}$ & $\mathrm{K}_{\mathbf{d}}$ & {$\left[\mathrm{NaNO}_{3}\right], \mathrm{M}$} & $\mathrm{K}_{\mathbf{d}}$ \\
\hline 0 & 4500 & 2.0 & 190 \\
\hline 0.5 & 575 & 3.0 & 142 \\
\hline 1.0 & 340 & 5.0 & 122 \\
\hline
\end{tabular}

The sorption of $\mathrm{Np}(\mathrm{V}), \mathrm{Np}(\mathrm{VI}), \mathrm{Pu}(\mathrm{VI})$, and $\mathrm{Tc}(\mathrm{VII})$ from 1 to $4 \mathrm{M} \mathrm{NaOH}$ on the macroporous strong-basic anion exchange resin VP-1AP (a vinylpyridine) was studied in the laboratory of electrochemistry of actinides and technetium of the Institute of Physical Chemistry of Russian Academy of Sciences (the head of laboratory is Professor V. F. Peretrukhin). The data are shown in Table 6-2. It is seen that all the studied elements are anionic in alkaline solutions and have high affinity for the anion exchange resin.

Table 6-2. Distribution Coefficients $\left(\mathrm{K}_{\mathrm{d}}\right)$ of Actinides(V), Actinides(VI), and Technetium(VII) for $\mathrm{NaOH}$ Solutions and the Anion Exchange Resin VP-1AP.

\begin{tabular}{|c|c|c|c|c|}
\hline \multirow{2}{*}{ Element } & \multicolumn{4}{|c|}{ Concentration of NaOH, M } \\
\cline { 2 - 5 } & 1 & 2 & 3 & 4 \\
\hline $\mathrm{Np}(\mathrm{V})$ & 32 & 94 & 132 & 177 \\
\hline $\mathrm{Np}(\mathrm{VI})$ & 325 & 152 & 61 & 30 \\
\hline $\mathrm{Pu}(\mathrm{VI})$ & 368 & 143 & 76 & 32 \\
\hline $\mathrm{Tc}(\mathrm{VII})$ & 6233 & 6155 & 5683 & 5193 \\
\hline
\end{tabular}

\subsection{EXTRACTION}

The discovery of $\mathrm{Np}(\mathrm{VII})$ and $\mathrm{Pu}$ (VII) stimulated the study of extraction from alkaline solutions. In the first work on this topic, it was found that $\mathrm{Np}$ (VII) is not extracted from 
0.1 to $4 \mathrm{M} \mathrm{NaOH}$ by solutions of the salts of organic cations (of butyl rhodamine and tetraphenyl arsonium) in $\mathrm{CHCl}_{3}$ and $\mathrm{C}_{2} \mathrm{H}_{4} \mathrm{Cl}_{2}$ (Novikov et al. 1972b). Butyl and isopropyl alcohols, diethyl ketone, and amyl and butyl acetates were also ineffective extractants.

A considerable transfer of neptunium into the organic phase is observed upon contacting alkaline solutions of $\mathrm{Np}$ (VII) with solutions of dibenzoylmethane (DBM) in butyl acetate, diethyl ether, and diethyl ketone. The best diluent for DBM is butyl acetate. Under otherwise similar conditions, the maximum isolation of neptunium takes place from $0.6 \mathrm{M} \mathrm{NaOH}$. The completeness of extraction increases with increasing extractant concentration. With $0.1 \mathrm{M} \mathrm{DBM}$, neptunium is transferred into the organic phase virtually completely. The distribution coefficient, $\mathrm{D}$, does not depend on the neptunium concentration within the range of $9 \times 10^{-5}$ to $3.6 \times 10^{-4} \mathrm{M}$.

The neptunium in the organic phase is hexavalent. The back-extraction of neptunium proceeds with $4 \mathrm{M} \mathrm{NaOH}$. No $\mathrm{Np}$ (VII) was detected in the back-extract. Hence, $\mathrm{Np}(\mathrm{VII})$ is transferred into the DBM organic phase where it is reduced to $\mathrm{Np}(\mathrm{VI})$ to form a complex. The composition of the extracting complex (metal:ligand) is 1:2.

The behavior of Pu(VII) upon extraction from alkaline media by DBM solutions in butyl acetate is analogous to that of $\mathrm{Np}(\mathrm{VII})$ (Vaidyanathan et al. 1972). The distribution coefficient of $\mathrm{Pu}(\mathrm{VII})$ between the organic phase and $0.6 \mathrm{M} \mathrm{NaOH}$ is not dependent on $\mathrm{Pu}$ (VII) concentration within the range of $(1$ to 3$) \times 10^{4} \mathrm{M}$. The distribution coefficient increases with increasing extractant concentration within the range of $2 \times 10^{-3}$ to $5 \times 10^{-2} \mathrm{M}$, reaching the value of 475 for $0.05 \mathrm{M}$ DBM. The dependence of $D$ on extractant concentration corresponds to the formation of a compound with the ratio Pu:DBM of 1:2 in the organic phase. Taking into account the potentials of the pairs $\mathrm{Pu}(\mathrm{VII}) / \mathrm{Pu}(\mathrm{VI})$ and $\mathrm{Np}$ (VII)/Np(VI), and the behavior of $\mathrm{Np}$ (VII) upon the contact with the DBM solution, it is possible to suggest that $\mathrm{Pu}(\mathrm{VII})$ is reduced to $\mathrm{Pu}(\mathrm{VI})$ upon extraction.

The $\mathrm{D}$ value for $\mathrm{Pu}(\mathrm{VI})$ extraction under the same conditions is about 16 (Vaidyanathan et al. 1972). It follows that initially the Pu(VII) is transferred into the organic phase where the $\mathrm{Pu}$ (VII) then is reduced.

The extraction of $\mathrm{Pu}$ (VII) from alkaline solutions by various compounds was studied (Rozen et al. 1990; Karalova et al. 1990a; Karalova et al. 1992a; and Karalova et al. 1992b). The neutral extractants (tributyl phosphate (TBP), and trioctyl phosphine oxide, TOPO) do not extract Np(VII) (Rozen et al. 1990). Dicyclohexyl-18-crown-6 (1 M) in 100\% TBP is also ineffective; the D value for $2 \mathrm{M} \mathrm{KOH}$ is about 0.005 . Tetratolylmethylene diphosphine dioxide $(1 \mathrm{M})$ in $100 \%$ TBP extracts $\mathrm{Np}(\mathrm{VII})$ from $1.7 \mathrm{M} \mathrm{NaOH}$ with a distribution coefficient of 0.012 . The same result was obtained when methyl isobutyl ketone was used as a diluent (Rozen et al. 1990).

The extraction of $\mathrm{Np}$ (VII) by different solvents in the presence of tetrazolium salts was also studied. In this case, the transition of neptunium into the organic phase is also small (the D value for $0.5 \mathrm{M} \mathrm{KOH}$ is 0.001 to 0.1) (Karalova et al. 1990a). 
Some success was achieved using alkylphenols $\mathrm{RC}_{6} \mathrm{H}_{4} \mathrm{OH}$ (where $\mathrm{R}$ is $\mathrm{C}_{7}$ to $\mathrm{C}_{9}$ ), p-tert-butylphenol, and polyalkylphenols (Rozen et al. 1990). Alkylphenolic extractants were studied in more detail (Karalova et al. 1990a; Karalova et al. 1992a; and Karalova et al. 1992b). The extractants used and the D values obtained are shown in Table 6-3.

All the tested systems extract neptunium into the organic phase. HABA and YB transfer neptunium more completely into the organic phase. The composition of the aqueous phase has a considerable effect on the $D$ values for neptunium. The maximal $D$ value of about 10 is achieved in 0.5 and $1.0 \mathrm{M}$ solutions of $\mathrm{NaOH}$ in the cases of HABA and YB respectively. Further increase in the alkali concentration in the case of HABA gives rise to a more dramatic decrease in the $D$ values than in the case of YB. At the same time HABA can be used in a wider range of $\mathrm{NaOH}$ concentrations in comparison with $\mathrm{YB}$, although the isolation of neptunium by $\mathrm{HABA}$ from $5 \mathrm{M} \mathrm{NaOH}$ does not exceed $5 \%$.

Table 6-3. The Distribution Coefficients (D) of Neptunium for the System Phenolic Extractant - 0.5 M NaOH (Karalova et al. 1990a).

\begin{tabular}{|l|c|c|c|c|}
\hline \multicolumn{1}{|c|}{ Extractant } & $\begin{array}{c}\text { Abbreviated } \\
\text { name }\end{array}$ & $\begin{array}{c}\text { Molecular } \\
\text { mass }\end{array}$ & Solvent & D \\
\hline 4-( $\alpha, \alpha$-Dioctylethyl)-pyrocatechol & DOEP & 362 & Toluene & 0.92 \\
\hline 2-Hydroxy-5-alkylbenzyldiethanolamine & HABD & 320 & Hexane & 0.89 \\
\hline Bis(2-hydroxy-5-alkyl-benzyl)amine & HABA & 465 & CCl $_{4}$ & 8.14 \\
\hline $\begin{array}{l}\text { Nitrogen-containing oligomer of } \\
\text { alkylphenol }\end{array}$ & $\begin{array}{c}\text { Yarrezine B } \\
\text { (YB) }\end{array}$ & 460 & Toluene & 4.83 \\
\hline $\begin{array}{l}\text { Sulfur-containing oligomer of } \\
\text { alkylphenol }\end{array}$ & $\begin{array}{c}\text { Octophor } \\
10 \mathrm{~S}\end{array}$ & 1150 & Toluene & 1.36 \\
\hline $\begin{array}{l}\text { Oxygen-containing oligomer of } \\
\text { alkylphenol }\end{array}$ & $\begin{array}{c}\text { Reagent } \\
101 \mathrm{~K}\end{array}$ & 520 & Toluene & 0.98 \\
\hline
\end{tabular}

The completeness of extraction increases with increasing contact with the extractant and with increasing duration of the phase contact. The $\mathrm{D}$ values for neptunium increase with time; the rate of establishment of the equilibrium depends on the alkali concentration. Ten minutes are required for equilibrium upon extraction by oligomer $\mathrm{YB}$ from $0.5 \mathrm{M} \mathrm{NaOH}$, and not less than 30 minutes are required from $2 \mathrm{M} \mathrm{NaOH}$.

The composition of the extracting compound has a metal:ligand ratio of 1:1 (Karalova et al. 1990a; and Karalova et al. 1992a). The D values for neptunium between 0.1 M YB in toluene and $1 \mathrm{M} \mathrm{NaOH}$ do not depend on the initial concentration of neptunium within the range of $10^{-5}$ to $10^{-3} \mathrm{M}$ (Karalova et al. 1990a). 
In the case of HABA, the $\mathrm{D}$ values for neptunium do not depend on its initial concentration (up to $10^{-4} \mathrm{M}$ ); at higher concentrations they decrease. The coefficients do not change with increasing the speed of stirring. This indicates that the role of diffusion upon extraction is negligible. Increase in temperature from 20 to $40{ }^{\circ} \mathrm{C}$ improves the extraction of neptunium.

Study of the isotherm of extraction of neptunium from 0.5 to $2.0 \mathrm{M} \mathrm{NaOH}$ by HABA was carried out to determine the capacity of the extractant for neptunium. The concentration of neptunium in the organic phase increases with increasing concentration in the aqueous phase and reaches a maximum at the concentration of $1.89 \mathrm{~g} / \mathrm{L}$ in the aqueous phase. The capacity of the extractant $\left(0.1 \mathrm{M} \mathrm{HABA}\right.$ in $\left.\mathrm{CCl}_{4}\right)$ was found to be $0.5 \mathrm{~g} \mathrm{~Np} / \mathrm{L}$.

Salts have a considerable effect on the extraction of $\mathrm{Np}$ (VII) by HABA solution. The addition of $\mathrm{KCl}$ increases the extraction; $\mathrm{K}_{2} \mathrm{CO}_{3}$ decreases the extraction (Karalova et al. 1992a; and Karalova et al. 1992b).

Neptunium(VI) in the NaOH solution - HABA system is extracted slower, and with a lower value of $\mathrm{D}$, than $\mathrm{Np}$ (VII). For instance, $\mathrm{Np}$ (VI) requires 3.5 hours to achieve equilibrium (D is about 3) in the system $0.1 \mathrm{M} \mathrm{HABA}$ in $\mathrm{CCl}_{4}-0.5 \mathrm{M} \mathrm{NaOH}$; $\mathrm{Np}(\mathrm{VII})$ requires 0.5 hours (D is about 10) (Karalova et al. 1992a; and Karalova et al. 1992b).

The stability of $\mathrm{Np}$ (VII) during extraction was studied by spectrophotometry. Np(VII) is not reduced to $\mathrm{Np}$ (VI) by short contact of its alkaline solutions with HABA. The reduction of $\mathrm{Np}$ (VII) to $\mathrm{Np}$ (VI) occurs in the organic phase after extraction. In the organic phase, the neptunium is only in the hexavalent state; $\mathrm{Np}$ (VII) was not detected in the back-extract. The shape of the NMR ${ }^{13} \mathrm{C}$ spectra of the loaded alkylphenolic extractants indicates that neptunium complexes form by substituting for protons in the hydroxyl groups of the extractant; the complex has paramagnetic properties. These observations confirm the presence of the hexavalent state (Karalova et al. 1992a; and Karalova et al. 1992b).

The degree of neptunium back-extraction by alkaline solution does not exceed $50 \%$ and is independent of the duration of the phase contact, the extractant concentration, and the time of standing of the extracts. Good back-extraction of neptunium occurs by mineral acid solutions (Karalova et al. 1992a).

Extraction of easily-hydrolyzed species, such as the tri- and tetravalent actinides, from alkaline solutions is possible only in the presence of complexing ligands capable of retaining these elements in alkaline media in the form of the stable anionic complexes. Organic ligands ( $\alpha$-hydroxycarboxylates and aminopolycarboxylates) and inorganic carbonate ligands are used as complexing agents.

To date, extraction systems with quaternary ammonium bases (QAB), primary amines, $\beta$-diketones, alkylpyrocatechols, alkyl derivatives of aminoalcohols, and condensed alkylaminophenols have been studied (Pal'shin et al. 1978; Karalova et al. 1978; Karalova et al. 1979; Nekrasova et al. 1979; Myasoedov et al. 1979; Myasoedov et al. 1980a; Nekrasova et al. 1981; Karalova et al. 1982; Bukina et al. 1983; 
Karalova and Myasoedov 1984; Karalova et al. 1985a; Karalova et al. 1985b; Mahajan et al. 1986; Karalova et al. 1989c; Karalova et al. 1983a; Karalova et al. 1985c; Myasoedov et al. 1980b; Karalova et al. 1981; Karalova et al. 1983b; Karalova et al. 1984a; Karalova et al. 1984b; Karalova et al. 1987b; Karalova et al. 1986; Karalova et al. 1987c; Karalova et al. 1987a; Karalova et al. 1989b; Karalova et al. 1989a; Bukina et al. 1990; Karalova et al. 1991; and Lavrinovich et al. 1993). The results obtained with these systems are considered briefly.

\subsubsection{Extraction by Aliquat-336}

Aliquat-336 (i.e., trialkylmethylammonium chloride, where alkyl is $C_{8}$ to $C_{10}$ ) was one of the QABs studied. The behavior of Am(III), Am(V), La(III), Eu(III), Th(IV), Pu(IV), U(VI), and some other elements upon extraction by Aliquat-336 solutions in cyclohexane or xylene from alkaline solutions was studied (Pal'shin et al. 1978; Karalova et al. 1978; Karalova et al. 1979; Nekrasova et al. 1979; Myasoedov et al. 1979; Myasoedov et al. 1980a; Nekrasova et al. 1981; Karalova et al. 1982; Bukina et al. 1983; Karalova and Myasoedov 1984; Karalova et al. 1985a; Karalova et al. 1985b; Mahajan et al. 1986; and Karalova et al. 1989c). Micro- and macroamounts of Am(III) and Eu(III) are extracted most completely by $0.1 \mathrm{M}$ Aliquat-336 solution in cyclohexane in the presence of $2.5 \times 10^{-2} \mathrm{M}$ tartrate or trihydroxyglutarate in 0.15 to $0.5 \mathrm{M} \mathrm{NaOH}$. Further increase in the $\mathrm{NaOH}$ concentration decreases the isolation degree $(R, \%)$ of the element into the organic phase. Extraction from $0.5 \mathrm{M} \mathrm{NaOH}$ decreases with increasing $\alpha$-hydroxycarboxylate concentration.

Hydroxydicarboxylates (tartrate, trihydroxyglutarate) provide better extraction by Aliquat-336 from the more concentrated alkaline solutions than hydroxymonocarboxylates (glycerate, gluconate).

Extraction of $10^{-6} \mathrm{M} \mathrm{Pu}(\mathrm{IV})$ from $\mathrm{NaOH}$ solutions in the presence of tartrate by a $20 \%$ solution of Aliquat-336 in xylene was investigated (Mahajan et al. 1986). The $R$ value for $\mathrm{Pu}(\mathrm{IV})$ at $0.2 \mathrm{M} \mathrm{NaOH}$ increases from 32 to $98 \%$ by increasing the Aliquat-336 concentration from 0.04 to $0.2 \mathrm{M}$. Increase in the $\mathrm{NaOH}$ concentration from 0.2 to $0.5 \mathrm{M}$ (at $0.4 \mathrm{M}$ tartrate) decreases the $\mathrm{R}$ value from 89 to $4.2 \%$.

The dependence of $\log \mathrm{D}$ on $\log$ extractant concentration shows that a solvate with 3 molecules of extractant is extracted into the organic phase.

Penta- and hexavalent actinides are extracted less effectively than the trivalent actinides. For instance, the $\mathrm{D}$ values for $\mathrm{Am}(\mathrm{V})$ upon extraction from $\mathrm{NaOH}$ solutions containing $2.5 \times 10^{-2} \mathrm{M}$ tartrate are less by an order of magnitude than the values for Am(III).

${ }^{3}$ Aliquat is a trademark of Henkel Corporation, Gulph Mills, Pennsylvania. 
Study of the extraction of Am(III) and other elements in the presence of chelating agents has shown that the $\mathrm{D}$ value depends on $\mathrm{NaOH}$ concentration (see Figure 6-1). The nature of the chelating agent has a considerable effect on the extraction of ions such as Am(III) and Eu(III). Aromatic hydroxy-functionalized chelating agents allow extraction within a wider range of alkali concentration in comparison with extraction by aliphatic hydroxyfunctionalized chelating agents. The derivatives of polymethylene diaminotetraacetate (dihydroxydiaminobutanetetraacetate, DHBTA; and hydroxydiethylenetriaminotetraacetate, HDETTA) are more effective than chelating agents containing hydroxyalkyl groups (hydroxyethyldiethylenetriaminotetraacetate, HEDTTA; and hydroxyethylethylenediaminotriacetate, HEDTA).

Figure 6-1. Extraction of Actinides from Alkaline Solutions.

Extractant: $0.2 \mathrm{M}$ Aliquat-336 in cyclohexane.

Medium: $\mathrm{NaOH}$ and $2 \times 10^{-3} \mathrm{M}$ DHBTA (dihydroxydiaminobutanetetraacetate).

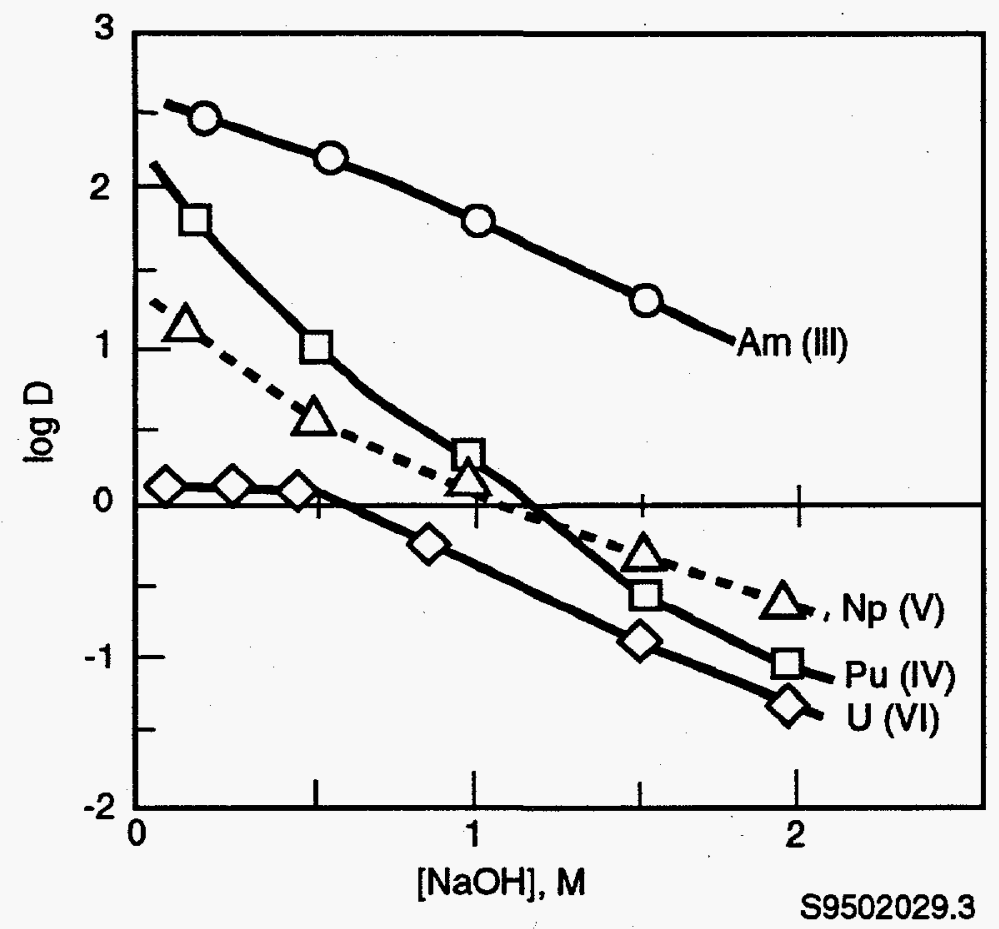


The behavior of $\mathrm{Am}(\mathrm{III}), \mathrm{Cm}(\mathrm{III})$, and $\mathrm{Eu}(\mathrm{III})$ in the system: Aliquat-336 - NaOH - EDTA was studied in an extraction-chromatographic technique (Bukina et al. 1983). The influence of the concentration of $\mathrm{NaOH}$ and EDTA on the $\mathrm{D}$ values was considered. For instance, the $D$ value for Am(III) with $0.01 \mathrm{M}$ EDTA decreases from 30 to 2.5 when $\mathrm{NaOH}$ concentration increases from 0.1 to $1 \mathrm{M}$.

\subsubsection{Extraction by Amines}

Tri-, tetra-, and hexavalent actinides are extracted from carbonate solutions by alkylamines in chloroform, xylene, cyclohexane, and other diluents (Karalova et al. 1983a; and Karalova et al. 1985c). The most effective extractants are the salts of primary amines.

\subsubsection{Extraction by Alkylpyrocatechols}

Alkylpyrocatechols are effective extractants for the isolation of many elements from alkaline and carbonate solutions (Myasoedov et al. 1980a; Karalova et al. 1982; Karalova and Myasoedov 1984; Karalova et al. 1985b; Karalova et al. 1985a; Karalova et al. 1989c; Myasoedov et al. 1980; Karalova et al. 1981; Karalova et al. 1983; Karalova et al. 1984a; Karalova et al. 1984b; Karalova et al. 1987b). Extraction of lanthanides and actinides by means of 4-( $\alpha, \alpha$-dioctylethyl)pyrocatechol (DOP) and the mixture of mono- and didecylpyrocatechols (TAP) in toluene and cyclohexane was investigated.

DOP is one of the few reagents isolating microamounts of Am(III) and Eu(III) from concentrated alkaline solutions in the absence of complexing agents. Almost complete extractions are obtained ( 96 to $97 \%$ by means of $0.04 \mathrm{M}$ DOP in toluene from 0.5 to $5 \mathrm{M} \mathrm{NaOH}$ within $30 \mathrm{~min}$ ) when freshly-prepared solutions are used. In the presence of tartrate, the $\mathrm{D}$ value for $\mathrm{Am}$ (III) increases dramatically with increasing $\mathrm{NaOH}$ concentration from 0.1 to $9.5 \mathrm{M}$; extraction reaches a maximum at $2 \mathrm{M} \mathrm{NaOH}$ and remains constant up to $10 \mathrm{M} \mathrm{NaOH}$.

Extraction of Eu(III) from dilute alkaline solutions depends upon the nature of the diluent. The $\mathrm{D}$ value decreases in the order: cyclohexane $>$ toluene $>$ chloroform $>$ octyl alcohol. $\mathrm{Eu}(\mathrm{III})$ is extracted to $99 \%$ from $5 \mathrm{M} \mathrm{NaOH}$ independent of the nature of diluent (excluding octyl alcohol).

Extraction of $\mathrm{Pu}(\mathrm{IV}), \mathrm{Th}(\mathrm{IV}), \mathrm{U}(\mathrm{VI}), \mathrm{Fe}(\mathrm{III}), \mathrm{Ru}(\mathrm{III}), \mathrm{Zr}(\mathrm{IV}), \mathrm{Nb}(\mathrm{V})$, and $\mathrm{Cs}(\mathrm{I})$ by $\mathrm{DOP}$ was studied. It was found that tetravalent elements in 0.5 to $3 \mathrm{M} \mathrm{NaOH}$ in the presence of $1 \times 10^{-4} \mathrm{M}$ diethylenetriaminopentaacetate have higher $\mathrm{D}$ values than trivalent elements. The $\mathrm{D}$ values of pentavalent elements are very low. Fe(III) is extracted with a high $\mathrm{D}$ value. 
Figure 6-2. Extraction of Am(III) and Eu(III) from Alkaline Solutions with DOP $([4(\alpha, \alpha)$ dioctylethyl $]$ pyrocatechol $)$.

$0.4 \mathrm{M}$ DOP Solution in Toluene.

Curves 1 and 2: $\mathrm{K}_{2} \mathrm{CO}_{3}$ Solution without $\mathrm{NaOH}$.

Curve 3: $\mathrm{K}_{2} \mathrm{CO}_{3}$ Solution with $0.5 \mathrm{M} \mathrm{NaOH}$.

Curve 4: $\mathrm{K}_{2} \mathrm{CO}_{3}$ Solution with $2 \mathrm{M} \mathrm{NaOH}$.

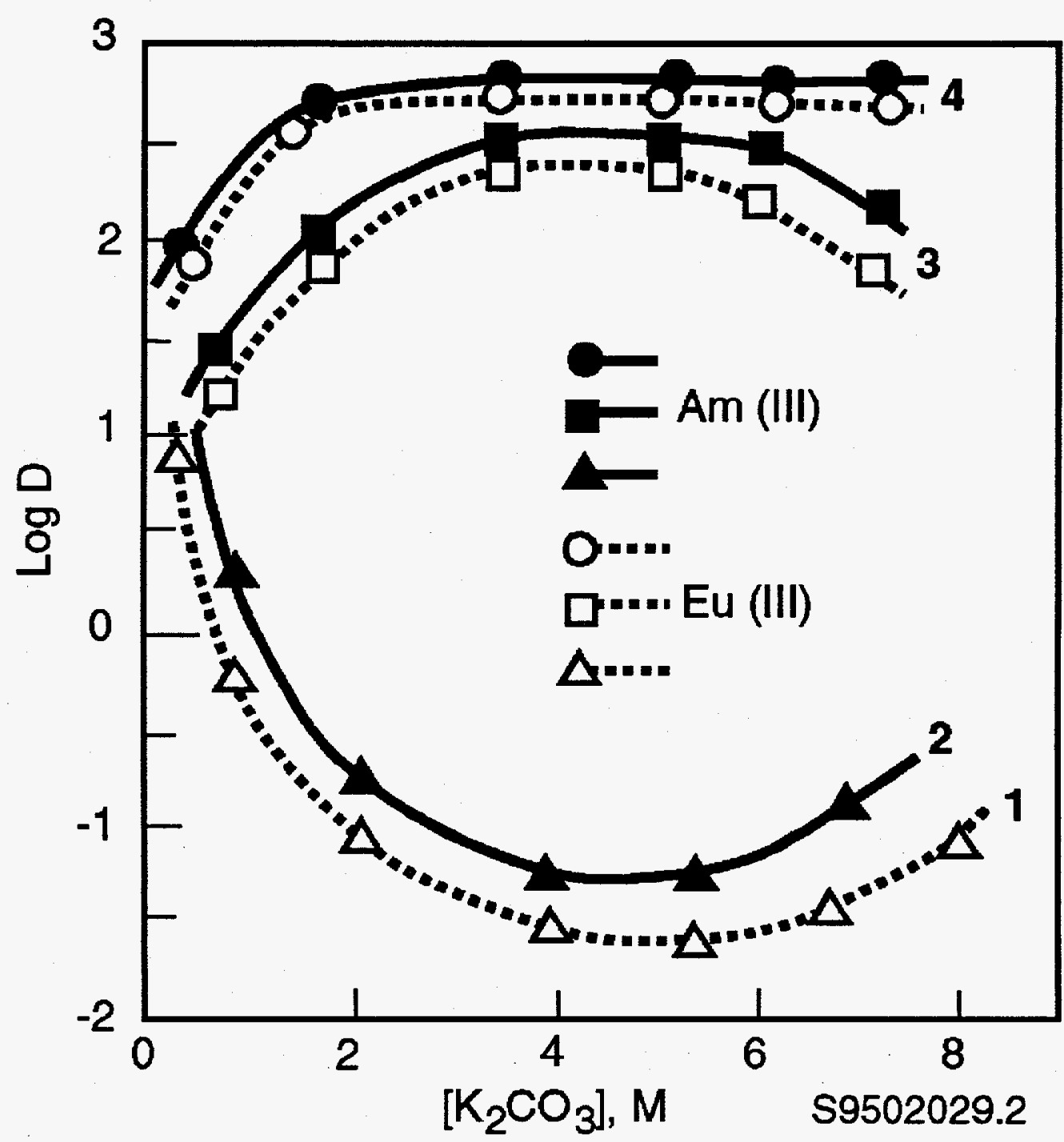


DOP isolates trivalent lanthanides and transplutonium elements from carbonate solutions. Figure 6-2 shows the dependencies of the D values for Am(III) and Eu(III) extraction by a $0.4 \mathrm{M}$ solution of DOP in toluene on the carbonate and hydroxide aqueous concentrations. These elements are extracted well from the solutions with less than $0.5 \mathrm{M} \mathrm{K}_{2} \mathrm{CO}_{3}$. Increasing the $\mathrm{K}_{2} \mathrm{CO}_{3}$ concentration to $3 \mathrm{M}$ leads to a two-order decrease in the $\mathrm{D}$ value.

Extraction increases dramatically with the addition of $\mathrm{NaOH}$. At $\mathrm{NaOH}$ concentrations greater than $0.5 \mathrm{M}$, the $\mathrm{D}$ value is 500 within a wide range of $\mathrm{K}_{2} \mathrm{CO}_{3}$ concentrations.

Similar dependencies were obtained with the use of mixtures of mono- and bidecylpyrocatechol solutions in chloroform, cyclohexane, or toluene.

\subsubsection{Extraction by $\beta$-Diketones}

Extraction of U(VI), Th(IV), Pu(IV), Am(III), $\mathrm{Cm}(\mathrm{III})$, and $\mathrm{Eu}(\mathrm{III})$ from $\mathrm{KHCO}_{3}$ and $\mathrm{K}_{2} \mathrm{CO}_{3}$ solutions by means of thenoyltrifluoroacetone and 1-phenyl-3-methyl-4-benzoylpyrazolone-5 in methyl isobutyl ketone was studied (Karalova et al. 1986; and Karalova et al. 1987c). The composition of the extracted compounds was established. $\beta$-Diketones isolate many elements almost completely within a wide range of $\mathrm{CO}_{3}^{2-}$ concentrations. Extractions of actinides decrease in the order: $\mathbf{M}(\mathrm{III})>\mathrm{M}(\mathrm{IV})>\mathrm{M}(\mathrm{VI})$.

\subsubsection{Extraction by Alkylaminoalcohols and Alkylphenols}

To isolate lanthanides and actinides from alkaline solutions in the presence of tartrate and carbonate, it is possible to use alkyl derivatives of aminoalcohols (Karalova et al. 1987a; Karalova et al. 1989b; Karalova 1989a; Bukina et al. 1990; Karalova et al. 1990b; and Lavrinovich et al. 1993). Extraction of Am(III), Eu(III), U(VI), and other elements by 2-hydroxy-5-alkylbenzyldiethanolamine (HABD) in different solvents was investigated. Am(III) is extracted completely from tartrate alkaline solutions by $0.1 \mathrm{M}$ HABD in hexane. Increase in the $\mathrm{NaOH}$ concentration from 0.01 to $10 \mathrm{M}$ gives rise to an increase in the $\mathrm{D}$ value from 10 to about 30 in $\left(1 \times 10^{-2} \mathrm{M}\right.$ tartrate). The nature of the diluent has an effect on the $\mathrm{D}$ value in the case of low alkali concentration. The $\mathrm{D}$ value decreases in the row: cyclohexane $>$ hexane $>$ chloroform $>$ isoamyl alcohol. Change of diluent upon extraction from $2 \mathrm{M} \mathrm{NaOH}$ has a small influence on the $\mathrm{D}$ values (excluding isoamyl alcohol).

Increase in the sodium tartrate concentration from 0.001 to $0.1 \mathrm{M}$ slightly changes the $\mathrm{D}$ values for $\mathrm{Am}$ (III) and $\mathrm{Eu}(\mathrm{III})$. Further increase in the tartrate concentration (to $1 \mathrm{M}$ ) decreases extraction.

Change of conditions slightly influences extraction of U(VI), $\operatorname{Ru}(\mathrm{IV}), \mathrm{Cr}(\mathrm{III}), \mathrm{Zr}(\mathrm{IV})$; their distribution coefficients are low. 
$\mathrm{Am}(\mathrm{III})$ and $\mathrm{Eu}(\mathrm{III})$ are extracted rather completely by $0.1 \mathrm{M}$ HABD from 0.01 to $0.1 \mathrm{M} \mathrm{K}_{2} \mathrm{CO}_{3}(\mathrm{R}=95$ to $98 \%)$. Increase in the $\mathrm{K}_{2} \mathrm{CO}_{3}$ concentration decreases the extraction of the metals into the organic phase; at $1 \mathrm{M} \mathrm{K}_{2} \mathrm{CO}_{3}$, both elements remain in the aqueous phase. The addition of $\mathrm{KOH}$ promotes extraction of $\mathrm{Am}$ (III) and $\mathrm{Eu}(\mathrm{III})$.

The phenolic-type extractants (HABA, YB and others, see Table 6-3) isolate not only $\mathrm{Np}$ (VII) from alkaline media, but also actinides in different oxidation states from carbonate solutions. In the case of $\mathrm{Am}(\mathrm{III})$, the $\mathrm{D}$ values increase with increasing $\mathrm{pH}$. The maximal value of $\mathrm{D}$ is observed for $1 \mathrm{M} \mathrm{K}_{2} \mathrm{CO}_{3}$. Both decrease and increase in the $\mathrm{K}_{2} \mathrm{CO}_{3}$ concentration decrease the $\mathrm{D}$ values. Tetra-, penta- and hexavalent actinides are extracted considerably worse (by 2 to 3 orders of magnitude) than the trivalent actinides.

\subsubsection{Extraction of Technetium}

Many types of organic compounds have been used as extractants for the isolation of Tc(VII) from alkaline solutions (Lavrukhina and Pozdnyakov 1966; and Spitsyn and Kuzina 1981). $\mathrm{Tc}$ (VII) is poorly extracted by aliphatic and aromatic hydrocarbons, their halogenated derivatives, and carboxylic acids. Some respective data are shown in Table 6-4.

In a homologous series of alcohols, aldehydes, or ketones, extraction decreases with an increase in the number of carbon atoms in the chain. Some examples are shown in Table 6-4.

Nitrogen-containing extractants (in particular, pyridine and its derivatives) are effective for technetium isolation.

Tributyl phosphate is one of the most important phosphorus-containing extractants. The $D$ value for $1 \mathrm{M} \mathrm{NaOH}$ is 7.5.

Extraction of $\mathrm{Tc}$ (VII) by pyridine depends on the presence of nitrate and other ions. Diffusion coefficients decrease considerably with increase in the nitrate concentration.

The possibility of isolation of $\mathrm{Tc}(\mathrm{VII})$ from 0.1 to $3.0 \mathrm{M} \mathrm{NaOH}$ by use of phenolic extractants was studied (Karalova et al. 1990a). The distribution coefficients for all such extractants are low. Therefore, these extractants are not used for isolation of $\mathrm{TcO}_{4}^{-}$from alkaline solutions.

Extraction of Tc(VII) in the form of the adducts with tetrazolium salts (previously used for the isolation of rhenium from alkaline solution) was also investigated (Karalova et al. 1990a; and Karalova et al. 1991a). The advantage of tetrazolium salts in comparison with organic cations such as tetraphenylarsonium and tetraphenylphosphonium is that they extract well even in very concentrated alkali solutions. Technetium is extracted by $5 \times 10^{-4} \mathrm{M}$ tetrazolium salt (especially, 2,3,5-triphenyltetrazolium chloride) in chloroform. The distribution coefficient increases from about 10 for $0.1 \mathrm{M} \mathrm{NaOH}$ to 30 for $1.5 \mathrm{M} \mathrm{NaOH}$. 
Extraction of $\mathrm{Tc}$ (VII) from alkaline solutions by crown compounds in different solvents was studied (Jalhoom 1986). The D values depend on the nature of alkali, increasing in the row: $\mathrm{LiOH}<\mathrm{NaOH}<\mathrm{KOH}$. Increase in the alkali concentration leads to an increase in the $D$ value. The efficiency of extraction depends on the nature of the diluent; it increases in the row: trichlorobenzene $<$ benzene $<$ chloroform $<$ chlorobenzene $<0$-dichlorobenzene $<1,2$-dichloroethane $<$ nitrobenzene. The distribution coefficient for extraction by $0.01 \mathrm{M}$ dibenzo-18-crown-6 in nitrobenzene from $4 \mathrm{M} \mathrm{NaOH}$ is about 10 .

Table 6-4. Extraction of Tc(VII) from Solutions of $\mathrm{NaOH}$.

\begin{tabular}{|l|c|c|}
\hline \multicolumn{1}{|c|}{ Extractant } & {$[\mathrm{NaOH}, \mathrm{M}$} & $\mathrm{D}$ \\
\hline Benzene & 1 & 0.037 \\
\hline Toluene & 1 & 0.014 \\
\hline Dichloroethane & 1 & 0.007 \\
\hline Mixture of carboxylic acids & 1 & 0.001 \\
\hline$n$-Butyl alcohol & 1 & 0.6 \\
\hline Isoamyl alcohol & 1 & 0.1 \\
\hline Acetone & 2 & 61.2 \\
\hline Methyl ethyl ketone & 2 & 47.9 \\
\hline Methyl $n$-propyl ketone & 2 & 2.9 \\
\hline Cyclohexanone & 1 & 6.7 \\
\hline Methyl isobutyl ketone & 2 & 0.27 \\
\hline Pyridine & 3 & 239 \\
\hline$\alpha$-Picoline (2-methylpyridine) & 3 & 1970 \\
\hline Lutiodine (2,4-dimethylpyridine) & 3 & 1670 \\
\hline Aldehydine (5-ethyl-2-methylpyridine) & 3 & 930 \\
\hline Quinoline (benzo[b]pyridine) & 3 & 356 \\
\hline
\end{tabular}




\subsection{ELECTROCHEMICAL METHODS OF ACTINIDE AND TECHNETIUM ISOLATION FROM ALKALINE SOLUTIONS}

Electrochemical methods can be used for electrodeposition of actinides and technetium and for the destruction of nitrate and nitrite ions contained in alkaline wastes.

\subsubsection{Electrodeposition of Actinides and Technetium and Their Cementation by Metals from Alkaline Solutions}

Electrodeposition of mixed uranium(V,IV) hydroxides has been demonstrated from solutions of 0.5 to $4.0 \mathrm{M} \mathrm{NaOH}$ and $5 \times 10^{-5} \mathrm{M} \mathrm{U}(\mathrm{VI})$ on platinum or stainless steel cathodes with a current density of 0.4 to $0.5 \mathrm{~A} \mathrm{~cm}^{-2}$ at 25 to $60^{\circ} \mathrm{C}$. The ratio of catholyte volume to cathode area was $12 \mathrm{~cm}$, and 98 to $100 \%$ of the uranium was electrodeposited on the cathode after $40 \mathrm{~min}$ electrolysis (Zantuti et al. 1991). The presence of $0.5 \mathrm{M} \mathrm{Na}_{2} \mathrm{CO}_{3}, 2.0 \mathrm{M}$ $\mathrm{NaNO}_{3}, 2.0 \mathrm{M} \mathrm{NaNO}$, $0.2 \mathrm{M} \mathrm{NaF}$, and $0.5 \mathrm{M} \mathrm{H}_{2} \mathrm{O}_{2}$ in alkaline solution did not decrease the uranium yield (Zantuti et al. 1991; and Gurevich and Koval'skaya-Yachenko 1958). Uranium(V) and uranium(IV) have been determined in the electrodeposited film. The decrease in the current density from 0.4 to $0.02 \mathrm{~A} \mathrm{~cm}^{-2}$ resulted in increasing the electrolysis duration to 4 hours and decreasing the uranium yield as much as $90 \%$. Trace quantities of carrier-free ${ }^{239} \mathrm{Pu},{ }^{234} \mathrm{Th}$, and ${ }^{144} \mathrm{Ce}$ were added to the uranium solution. It has been shown that electrodeposition yields of these radionuclides are equal to the uranium yield for the duration of the electrolysis (Zantuti et al. 1991).

The electrodeposition of plutonium from solutions of 1.6 to $1.9 \mathrm{M} \mathrm{NaOH}$ and $10^{-5} \mathrm{M} \mathrm{Pu}(\mathrm{VI})$ has been studied by two groups of authors. The yield of plutonium on platinum and stainless steel was as high as 90 to $96 \%$ at a current density of $25 \mathrm{~mA} \mathrm{~cm}$ after $^{-2}$ hours electrolysis (Milyukova et al. 1969) and near 100\% at current density $40 \mathrm{~mA} \mathrm{~cm}$ after $^{-2}$ hours electrolysis (Miller and Brouns 1952).

Some time ago it was shown that technetium can be electrodeposited from a solution of 1 to $2 \mathrm{M} \mathrm{NaOH}$, and $10^{-4} \mathrm{M} \mathrm{Tc}(\mathrm{VII})$, at the cathode potential $-0.86 \mathrm{~V}$ (vs NHE) as Tc(IV) hydroxide (Rogers 1949). The yield of technetium electrodeposition from alkaline solution was not reported. Others indicated that Tc(IV) formed by the polarographical reduction of $\mathrm{TcO}_{4}^{-}$in $1 \mathrm{M} \mathrm{NaOH}$ is dissolved within 2 seconds after the formation (Founta et al. 1987). They explained this fact by the conversion of $\mathrm{Tc}$ (VII) electroreduction product to $\mathrm{TcO}_{2} \cdot \mathrm{xH}_{2} \mathrm{O}$ or by the existence of Tc(IV) amphoteric species stable thermodynamically in alkaline media. The published data are not sufficient to choose conditions for the quantitative electrodeposition of Tc from alkaline solutions.

The deposition of $\mathrm{Np}(\mathrm{V}), \mathrm{Np}(\mathrm{IV})$, and $\mathrm{Pu}(\mathrm{IV})$ hydroxides can be carried out from alkaline media, without an external electrical source, on aluminum and zinc foils. Films of $N p(V, I V)$ hydroxides on $\mathrm{Al}$ foil with thicknesses up to $0.6 \mathrm{mg} \mathrm{cm}^{-2}$ have been prepared by the plunging of $\mathrm{Al}$ foil into solutions of 0.3 to $0.5 \mathrm{M} \mathrm{NaOH}$ and $10^{-3}$ to $10^{-2} \mathrm{M} \mathrm{Np}$ (VII) for 10 to 20 minutes (Dzyubenko and Peretrukhin 1977). Thin films of $\mathrm{Pu}(\mathrm{IV})$ hydroxides have been 
prepared on $\mathrm{Al}$ and $\mathrm{Zn}$ foils from solutions of 0.5 to $1.0 \mathrm{M} \mathrm{NaOH}$ and $10^{-4} \mathrm{M} \mathrm{Pu}(\mathrm{VI})$ (Peretrukhin 1981). The films are uniform and have a good adhesion to $\mathrm{Al}$ and $\mathrm{Zn}$ pieces of any geometrical form. These investigations were carried out to develop techniques for actinide oxide film preparation. These works also indicate a possible method to separate actinides and technetium from alkaline wastes by electrodeposition or metal cementation. The simultaneous reduction of $\mathrm{CrO}_{4}^{2-}$ and other major components of alkaline wastes remains a problem to be investigated.

\subsubsection{Electrochemical Denitration of Alkaline Waste}

The electrolytic reduction of $\mathrm{NO}_{3}^{-}$and $\mathrm{NO}_{2}^{-}$in 1 to $3 \mathrm{M} \mathrm{NaOH}$ solutions has been studied on platinum, nickel, and stainless steel cathodes (Horanyi and Rizmayer 1985; and

$\mathrm{Li}$ et al. 1988). Two reduction processes have been reported for nitrate in alkaline solution:

$$
\begin{aligned}
& \mathrm{NO}_{3}^{-}+3 \mathrm{H}_{2} \mathrm{O}+5 \mathrm{e}^{-} \rightarrow 1 / 2 \mathrm{~N}_{2}+6 \mathrm{OH}^{-}\left(\mathrm{E}_{\text {cat }}=0.96 \mathrm{~V} \mathrm{NHE}\right) \\
& \mathrm{NO}_{3}^{-}+6 \mathrm{H}_{2} \mathrm{O}+8 \mathrm{e}^{-} \rightarrow \mathrm{NH}_{3}+9 \mathrm{OH}^{-}\left(\mathrm{E}_{\text {cat }}=1.46 \mathrm{~V} \mathrm{NHE}\right)
\end{aligned}
$$

Nitrite can be reduced to nitrogen at the less negative cathode potential, $\mathrm{E}_{\text {cal }}$, of $-0.60 \mathrm{~V}$. The reduction of nitrate to $\mathrm{N}_{2}$ in $3 \mathrm{M} \mathrm{NaOH}$ takes place at a current density of less than $0.107 \mathrm{~A} \mathrm{~cm}^{-2}$, and ammonia becomes the major electrolysis product at current densities greater than $0.466 \mathrm{~A} \mathrm{~cm}^{-2}$ ( $\mathrm{Li}$ et al. 1988). Denitration with $\mathrm{N}_{2}$ evolution is more suitable for industrial application because mixtures of ammonia with oxygen can be explosive.

The current efficiency of the $\mathrm{NO}_{3}^{-}$conversion to $\mathrm{N}_{2}$ in $3 \mathrm{M} \mathrm{NaOH}$ is high (up to $86 \%$ ) when the nitrogen is used for ventilation of the cell and up to $94 \%$ when an air stream is used for ventilation. Oxygen increases the current efficiency due to its reduction at the cathode to form $\mathrm{HO}_{2}^{-} ; \mathrm{HO}_{2}^{-}$seems to react rapidly with nitrate. The presence of $0.25 \mathrm{M} \mathrm{Na}_{2} \mathrm{CO}_{3}$ in the $\mathrm{NaOH}$ solution has no influence on the efficiency of electrolytic denitration. The effect of ruthenium, present in the $\mathrm{NaOH}$ solution, on the denitration process is described in reports (Alter et al. 1957; and Messing and Higgins 1957) not available in Russia.

The presence of $1 \times 10^{-4} \mathrm{M} \mathrm{Tc}(\mathrm{VII})$ facilitates denitration in 1 to $4 \mathrm{M} \mathrm{NaOH}$ solution when the ratio of catholyte volume to the cathode area is $20 \mathrm{~cm}$ (Silin and Peretrukhin 1994). But the formation of hydroxide films of $\mathrm{U}, \mathrm{Np}, \mathrm{Pu}$, and $\mathrm{Am}$ should be expected on the surface of the cathode during the denitration of alkaline wastes. The effect of actinide and other metal oxide films on the electrolytical denitration of alkaline waste has not been reported. 


\subsection{REFERENCES}

Alter, H. W., D. L. Barney, J. K. Davidson, A. C. Schafer, and F. J. Witt, 1957, Electrolytic Recycle Method for the Treatment of Radioactive Nitric Acid Waste, Knoll Atomic Power Lab., KAPL report No. 1721. Cit. from Li et al. 1988.

Bukina, T. I., Karalova Z. K., and B. F. Myasoedov, 1983, Radiokhimiya, 25, p. 697.

Bukina, T. I., Z. K. Karalova, and B. F. Myasoedov, 1990, Radiokhimiya, 32, No. 2, p. 11 .

Dzyubenko, V. I., and V. F. Peretrukhin, 1977, Radiokhimiya, 19, p. 832.

Founta, A., D. A. Aikens, and H. M. Clark, 1987, J. Electroanal. Chem., 219, p. 221.

Gurevich, M. L., and M. L. Koval'skaya-Yachenko, 1958, Tr. Radievogo Inst. Akad. Nauk SSSR, $\underline{8}$, p. 53 .

Horanyi, G., and E. M. Rizmayer, 1985, J. Electroanal. Chem., 188, p. 265.

Jalhoom, M. G., 1986, J. Radioanal. Nucl. Chem. Lett., 104, p. 131.

Karalova, Z. K., E. A. Lavrinovich, S. A. Ivanova, B. F. Myasoedov, L. A. Federov, and S. A. Sokolevskii, 1992a, Radiokhimiya, 34, No. 3, p. 132.

Karalova, Z. K., E. A. Lavrinovich, and B. F. Myasoedov, 1992b, J. Radioanal. Nucl. Chem., 159, p. 259.

Karalova, Z. K., E. A. Lavrinovich, and B. F. Myasoedov, 1991, Radiokhimiya, 33, No. 3, p. 70 .

Karalova, Z. K., E. A. Lavrinovich, S. A. Ivanova, and B. F. Myasoedov, 1990a, Radiokhimiya, $\underline{32}$, No. 5 , p. 81.

Karalova, Z. K., E. A. Lavrinovich, and B. F. Myasoedov, 1990b, Radiokhimiya, 32, No. 2 , p. 16 .

Karalova, Z. K., T. I. Bukina, E. A. Lavrinovich, and B. F. Myasoedov, 1989a, Radiokhimiya, 31 , No. 6, p. 81 .

Karalova, Z. K., E. A. Lavrinovich, B. F. Myasoedov, L. A. Fedorov, and S. A. Sokolevskii, 1989b, Radiokhimiya, 31, No. 5, p. 38.

Karalova, Z. K., B. F. Myasoedov, T. I. Bukina, and E. A. Lavrinovich, 1989c, Solvent Extraction and Ion Exchange, 6, p. 1109. 
Karalova, Z. K., T. I. Bukina, E. A. Devirts, Z. Z. Agaev, and B. F. Myasoedov, 1987a, Radiokhimiya, 29, p. 767.

Karalova, Z. K., T. I. Bukina, B. F. Myasoedov, L. A. Fedorov, and S. A. Sokolovski, 1987b, Radiokhimiya, 29, p. 335.

Karalova, Z. K., E. A. Devirts, and B. F. Myasoedov, 1987c, Radiokhimiya, 29, p. 33.

Karalova, Z. K., B. F. Myasoedov, E. A. Devirts, L. A. Fedorov, and M. S. Rukov, 1986, Radiokhimiya, 28, p. 47.

Karalova, Z. K., T. I. Bukina, and B. F. Myasoedov, 1985a, Radiokhimiya, 27, p. 751.

Karalova, Z. K., T. I. Bukina, and B. F. Myasoedov, 1985b, Radiokhimiya, 27, pp. 450.

Karalova, Z. K., B. F. Myasoedov, T. V. Bunina, and L. M. Rodionova, 1985c, Radiokhimiya, 27, p. 47.

Karalova, Z. K., and B. F. Myasoedov, 1984, Zh. Anal. Khim., 39, p. 119.

Karalova, Z. K., L. M. Rodionova, and B. F. Myasoedov, 1984a, Radiokhimiya, 26, p. 21.

Karalova, Z. K., L. M. Rodionova, B. F. Myasoedov, and V. S. Kuznetsova, 1984b, Radiokhimiya, 26, p. 24.

Karalova, Z. K., T. V. Bunina, and B. F. Myasoedov, 1983a, Radiokhimiya, 25, p. 595.

Karalova, Z. K., B. F. Myasoedov, L. M. Rodionova, and V. S. Kuznetsova, 1983b, Radiokhimiya, 25, p. 187.

Karalova, Z. K., L. M. Rodionova, and B. F. Myasoedov, 1982, Radiokhimiya, 24, p. 210.

Karalova, Z. K., B. F. Myasoedov, L. M. Rodionova, and V. S. Kuznetsova, 1981, Radiokhimiya, 23, p. 52.

Karalova, Z. K., L. M. Rodionova, Z. I. Pyzhova, and B. F. Myasoedov, 1979, Radiokhimiya, 21, p. 394.

Karalova, Z. K., V. V. Nekrasova, Z. I. Pyzhova, L. M. Rodionova, and B. F. Myasoedov, 1978, Radiokhimiya, 20, p. 845 .

Lavrukhina, A. K. and A. A. Pozdnyakov, 1966, Analiticheskaya Khimiya Tekhnetsiya, Prometiya, Asatina i Frantsiya, Nauka, Moscow, USSR, (in Russian). Available in English, Analytical Chemistry of Technetium, Promethium, Astatine, and Francium, 1970, Ann Arbor-Humphrey Science Publ., Ann Arbor, Michigan. 
Lavrinovich, E. A., Z. K. Karalova, and B. F. Myasoedov, 1993, Radiokhimiya, 35, No. 2, p. 99.

Li, H.-L., D. H. Robertson, J. Q. Chambers, and D. T. Hobbs, 1988, J. Electrochem. Soc., Electrochem. Science and Techn., 135, No. 5, p. 1154.

Mahajan, G. R., M. Ray, C. V. Karskar, V. K. Rao, and P. R. Natarajan, 1986, Radiochem. Radiat. Chem. Symp., Kanpur, December 9-13, 1985, Bombay, India, p. 458.

Marsh, S. F., 1993, Partitioning of HLW from Alkaline Solution. A Literature Survey, LA-12528, Los Alamos National Laboratory, Los Alamos, New Mexico.

Messing, A. F., and I. R. Higgins, 1957, An Electrolytic Procedure for the Removal of Ruthenium and Nitrate from Alkaline Waste Solutions, ORNL-2532, Oak Ridge National Laboratory, Oak Ridge, Tennessee. Cit. from (Li et al. 1988).

Metz, C. F., and G. R. Waterbury, 1962, Treatise on Analytical Chemistry. Part II, Section A, Vol. 9. "The Transuranium Actinide Elements," Interscience, a division of John Wiley and Sons, New York, New York.

Milyukova, M. S., N. I. Gusev, I. G. Sentyurin, and I. S. Sklyarenko, 1965, Analiticheskaye Khimiya Plutoniya, Nauka, Moscow, USSR, (in Russian). Available in English as Analytical Chemistry of Plutonium, 1969, Ann Arbor-Humphrey Science Publ., London, UK.

Milyukova, M. S., N. I. Gusev, I. G. Sentyurin, and I. S. Sklyarenko, 1969, Analytical Chemistry of Plutonium, 1969, Ann Arbor-Humphrey Science Publ., London, UK, pp. 120-121.

Miller, H. W. and R. J. Brouns, 1952, Anal. Chem., 24, p. 536.

Myasoedov, B. F., L. I. Guseva, I. A. Lebedev, M. S. Milyukova, and M. K. Chmutova, 1972, Analiticheskaya Khimiya Transplutonievykh, Nauka, Moscow, USSR, (in Russian). Available in English as Analytical Chemistry of Transplutonium Elements, 1974, John Wiley, New York, New York.

Myasoedov, B. F., Z. K. Karalova, and V. V. Nekrasova, 1979, Zh. Anal. Khim., 34, p. 1834.

Myasoedov, B. F., Z. K. Karalova, V. V. Nekrasova, and L. M. Rodionova, 1980a, J. Inorg. Nucl. Chem., 42, p. 1495.

Myasoedov, B. F., Z. K. Karalova, V. S. Kuznetsova, and L. M. Rodionova, 1980b, Radiokhimiya, 22, p. 347. 
Nekrasova, V. V., Z. K. Karalova, and B. F. Myasoedov, 1981, Radiokhimiya, 23, p. 259.

Nekrasova, V. V., Z. K. Karalova, and B. F. Myasoedov, 1979, Radiokhimiya, 21, p. 805.

Novikov, Yu. P., B. F. Myasoedov, and S. A. Ivanova, 1972a, Zh. Anal. Khim., 27, p. 63.

Novikov, Yu. P., B. F. Myasoedov, and S. A. Ivanova, 1972b, Radiochem. Radioanal. Lett., 9, p. 85.

Pal'shin, E. S., V. V. Nekrasova, A. A. Ivanova, Z. K. Karalova, and B. F. Myasoedov, 1978, Zh. Anal. Khim., 33, p. 878.

Peretrukhin, V. F., 1980, Electrochemical and Nuclear Chemical Reactions of Actinides in Solutions at High Oxidation and Reduction Potentials, Thesis for Professor Degree, Institute of Physical Chemistry, Academy of Science USSR, Moscow, USSR (in Russian).

Rimshaw, S. J. and G. F. Malling, 1961, Anal. Chem., $\underline{33}$, p. 751.

Rogers, L. B., 1949, J. Am. Chem. Soc., 71, p. 1507.

Rozen A. M., A. S. Nikiforov, N. A. Kartasheva, Z. I. Nikolotova, I. G. Tananaev, 1990, Dokl. Akad. Nauk SSSR, $\underline{312}$, p. 897.

Schulz, W. W., 1979, U.S. patent Nos. 4, 156, 646.

Seaborg, G. T., and J. J. Katz, Eds., 1954, The Actinide Elements, Natl., Nucl. En. Ser., Div. IV, Vol. 14A, McGraw-Hill, New York, New York.

Shiokawa, Y., Yamana H., Sato A., and Suzuki S., 1982, Bull. Chem. Soc. Japan., 55, p. 2051.

Silin, V. I., and V. F. Peretrukhin, Electrolytic Denitration in NaOH Solutions in the Presence of Technetium, Report of Institute of Physical Chemistry of Russian Academy of Science, Moscow, Russia, July 1994 (in Russian).

Spitsyn, V. I., and A. F. Kuzina, 1981, Technetium, Nauka, Moscow, USSR (in Russian).

Vaidyanathan, S., G. H. Rizvi, and P. R. Natarajan, 1972, Proc. Chem. Symp. Aligarth, India, $\underline{2}$, p. 207. 
Zakharova, F. A., M. M. Orlova, D. P. Alekseeva, and N. N. Krot, 1974, Radiokhimiya, 16 , p. 546.

Zantuti, F., B. Al-Medehem, V. I. Silin, and V. F. Peretrukhin, 1991, J. Radioanal. Nucl. Chem. Articles, 147, p. 51. 
This page intentionally left blank. 


\subsection{CONCLUSION}

Consideration of published data on the chemistry of transuranium elements and technetium in alkaline media allows us to draw the following conclusions and recommendations.

1. The thermodynamically-stable forms of actinide hydroxides, including $\mathrm{Pu}(\mathrm{V})$, and of technetium in 0.1 to $15 \mathrm{M} \mathrm{NaOH}$ were determined. It was shown that, in addition to the sparingly-soluble hydroxides of U(IV), Np(IV), and Tc(IV), hydroxides of Pu(IV) and Am(III) can be oxidized to the more soluble pentavalent and, in some cases, hexavalent states by mild oxidizing agents present in the alkaline tanked wastes of the Hanford Site. The ventilation of tanks by nitrogen (instead of air) can be recommended as one measure to decrease the actinide concentration in the solutions.

2. Data on the solubilities and the forms of existence of the hydroxide compounds of the actinides and technetium in alkaline media are incomplete and sometimes contradictory. Significantly, the solubilities of hydroxides of lanthanides, actinides, and technetium in alkali increase considerably in the presence of complexing agents. One of the important problems to be solved is the determination of the solubility of plutonium.

3. Consideration of the redox reactions of actinides in alkaline media allows one to choose reagents for the fast preparation of hydroxide compounds of actinides in valent states from VII to III in "pure" alkaline media. However, realization of the methods in the case of multi-component alkaline wastes requires experimental examination.

4. Information on the radiation-chemical properties of hydroxide compounds of actinides in valent states of V, IV, and III in alkaline media is absent; the same information for technetium is incomplete. There is an interesting possibility to use the radiation field of liquid wastes in Hanford tanks for the conversion of $\mathrm{Pu}(\mathrm{V}), \mathrm{Tc}(\mathrm{VII})$ and, apparently, $\mathrm{Np}(\mathrm{V})$ to sparingly-soluble hydroxides of actinides(IV) and technetium(IV) by using additives which are scavengers of the oxidative components of radiolysis. Conversely, conditions for oxidation of actinides in the lower valent states to actinides in higher valent states can be created by the addition of scavengers of the reductive components of radiolysis. In general, use of the respective additive may allow preparation of actinides in any desired oxidation state.

5. Electrochemical methods may be used to isolate actinides and technetium from alkaline solutions by electrodeposition, and by cementation on metals (e.g., $\mathrm{Al}, \mathrm{Zn}$ ).

Electroanalytical determination of these elements in solutions also may be performed.

6. Coprecipitation with hydroxides of d-elements (e.g., $\mathrm{Mn}, \mathrm{Fe}$ ), sorption on inorganic sorbents and strong-base macroporous anion exchange resins (e.g., vinylpyridines), and extraction can also be used for the separation of actinides and technetium from alkaline solutions. 
7. It is necessary to emphasize that all the isolation methods have been developed and studied for "pure" alkaline solutions. The behaviors of actinides and technetium in the presence of large amounts of $\mathrm{NO}_{3}^{-}, \mathrm{CrO}_{4}^{2-}$, aluminates, EDTA, and other complexing agents have not been investigated. The respective studies are required to develop technology for the isolation of actinides and technetium from real alkaline wastes.

\subsection{ACKNOWLEDGEMENT}

We thank Dr. Teresa Fryberger for her interest in our research and for recruiting us, as specialists in fundamental actinide alkaline chemistry, for work on the problem of alkaline radwastes.

We thank Mr. Calvin Delegard for the coordination of our efforts as applied to the Hanford Site tank waste problem and for his work editing the manuscript. We also gratefully acknowledge the efforts of Dr. Thomas Albert for a rapid solution of organizational problems. 


\section{DISTRIBUTION}

Number of Copies

OFFSITE

4

Argonne National Laboratory

9700 S. Cass Ave.

Argonne, IL 60439

E. P. Horwitz

K. L. Nash

D. T. Reed

Technical Library

1

Florida State University

Department of Chemistry, B164

Tallahassee, FL 32306-1096

G. R. Choppin

2

Lawrence Berkeley National Laboratory

One Cyclotron Road

University of California

Berkeley, CA 94720

D. A. Bennett

Technical Library

Lawrence Livermore National Laboratory

P. O. Box 808

Livermore, CA 94550

Z. Chiba

MS L-286

R. J. Silva

Technical Library 
DISTRIBUTION (Continued)

Number of Copies

OFFSITE

4

Los Alamos National Laboratory

P. O. Box 1663

Los Alamos, NM 87545

J. R. FitzPatrick

MS C346

N. Schroeder

MS J514

Z. V. Svitra

Technical Library

2

Mound Laboratory

Miamisburg, OH 45342

G. L. Silver

Technical Library

6

Oak Ridge National Laboratory

P. O. Box 2008

Oak Ridge TN 37831

J. T. Bell

MS 6223

W. D. Bond

MS 6385

E. Z. Egan

MS 6223

L. M. Toth

MS 6268

J. S. Watson

MS 6227

Technical Library

2

Sandia National Laboratory

P. O. Box 1663

Los Alamos, NM 87545

S. F. Marsh

MS E501

Technical Library 


\section{DISTRIBUTION (Continued)}

Number of Copies

OFFSITE

4

Savannah River Technical Center

P. O. Box 616

Aiken, SC 29808

D. T. Hobbs

773-A

D. G. Karraker

773-H

M. C. Thompson

Technical Library

1

Thomas Albert and Associates, Inc.

34931 U.S. Highway 19 North

Suite 205

Palm Harbor, FL 34684

T. E. Albert

2

United States Department of Energy

12800 Middlebrook Road

Trevion II Building

Germantown, MD 20874

T. Fryberger

Technical Library

1

University of Tennessee

Department of Chemistry

Knoxville, TN 37996

J. R. Peterson

1

W. W. Schulz

720 Montgomery Boulevard

Albuquerque, NM 87109 


\section{DISTRIBUTION (Continued)}

Number of Copies

\section{OFFSITE}

1

2

1

1

1

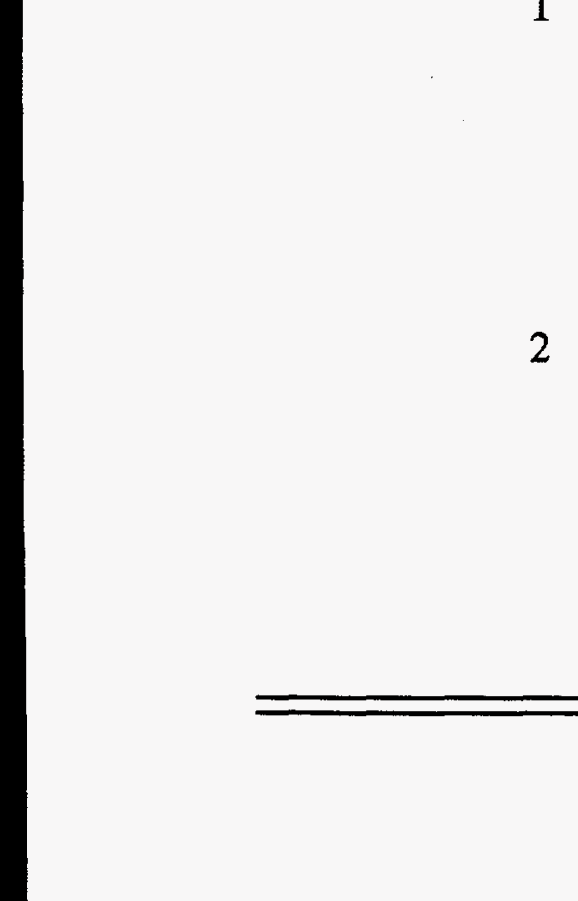

Centre d'Etudes Nucléaires

Section de Chimie de Haute Activité

Fontenay-aux-Roses Cedex, France F-92265

J. Bourges

Centre d'Etudes Nucléaires

Section de Géochimie

Fontenay-aux-Roses Cedex, France F-92265

H. Capdevila

P. Vitorge

Institut de Physique Nucléaire

BP. $\mathrm{N}^{\circ} 1$

Orsay Cedex, France F-91406

F. David

Fachbereich Anorganische Chemie

und Kernchemie der Technischen

Hochschule Darmstadt

Darmstadt, Germany D-64289

K. H. Lieser

Forschungszentrum Rossendorf, e.V.

Institut für Radiochemie

Postfach 510119

Dresden, Germany D-01314

H. Nitsche

Institut für Radiochemie

der Technischen Universität München

Garching, Germany D-85747

J. I. Kim

Ch. Lierse 


\section{DISTRIBUTION (Continued)}

Number of Copies

\section{OFFSITE}

36

\section{INTERNATIONAL}

Institute of Physical Chemistry

Russian Academy of Sciences

31 Leninsky Prospect

Moscow, Russia 117915

V. M. Gelis

N. N. Krot

A. G. Maslennikov

V. F. Peretrukhin (10)

A. K. Pikaev (10)

Yu. M. Polukarov

V. P. Shilov (10)

I. G. Tananaev

E. M. Zakharova

Studsvik Nuclear

Nyköping, Sweden S-61182

I. Puigdomènech

Svensk Kämbränslehantering AB

Box 5864

Stockholm, Sweden S-10248

Technical Library

4
Harwell Laboratory

Oxfordshire, United Kingdom OX11 ORA

F. T. Ewart

J. L. Smith-Briggs

H. P. Thomason

S. J. Williams 


\section{DISTRIBUTION (Continued)}

\section{Number of Copies}

\section{ONSITE}

MACTEC

D. J. Swanberg

$\mathrm{K} 8-50$

14

Pacific Northwest Laboratory

L. A. Bray

P7-25

N. G. Colton

K3-75

A. R. Felmy

K9-77

W. L. Kuhn

K2-21

G. J. Lumetta

P7-25

D. Rai

K9-77

L. Rao

K9-77

B. M. Rapko

P7-25

J. L. Ryan

P7-25

D. M. Strachan

K9-78

J. L. Swanson

P7-25

D. W. Wester

P7-25

PNL Technical Files

K1-11

Hanford Technical Library

P8-55

5

U.S. Department of Energy

Richland Field Office

J. E. Kinzer

S7-50

B. A. Mauss

K8-50

S. N. Runyon

K8-50

D. E. Trader

K8-50

Public Reading Room

A1-65

Westinghouse Hanford Company

H. Babad

G. S. Barney

T5-12

D. B. Bechtold

T6-09

R. A. Bechtold

L0-18

M. A. Beck

T6-09

J. D. Berger

L0-18 


\section{DISTRIBUTION (Continued)}

Number of Copies

ONSITE Westinghouse Hanford Company (Continued)
A. L. Boldt
H5-49
K. D. Boomer
H5-49
S. A. Catlow
T6-30
S. A. Colby
H5-27
T. D. Cooper
T5-12
C. H. Delegard (20)
T6-09
F. D. Fisher
T5-12
L. L. Fritts
T6-50
G. B. Griffin
T6-16
D. L. Herting
T6-09
B. E. Hey
T6-09
R. C. Hoyt
H5-38
J. R. Jewett
T6-09
R. A. Kirkbride
H5-27
B. G. Lauzon
R1-08
G. T. MacLean
H5-49
J. C. Person
T6-09
J. P. Sloughter
H5-27
OSTI (2)
L8-07
Central Files
L8-04 
This page intentionally left blank. 